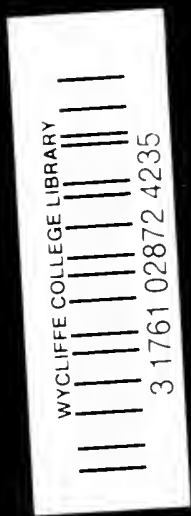

(1) 3 की

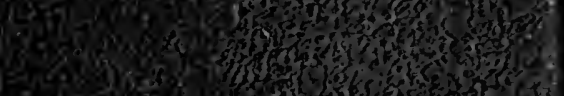
and

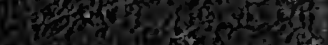

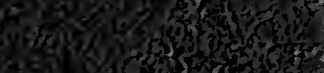

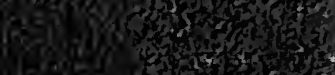

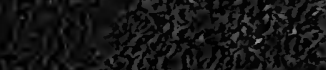

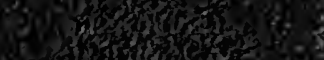

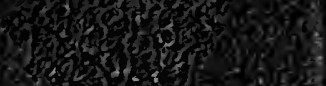
a

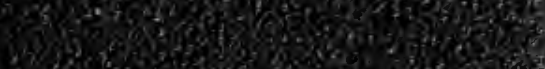

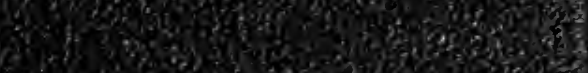

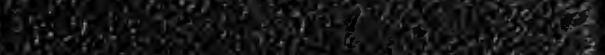

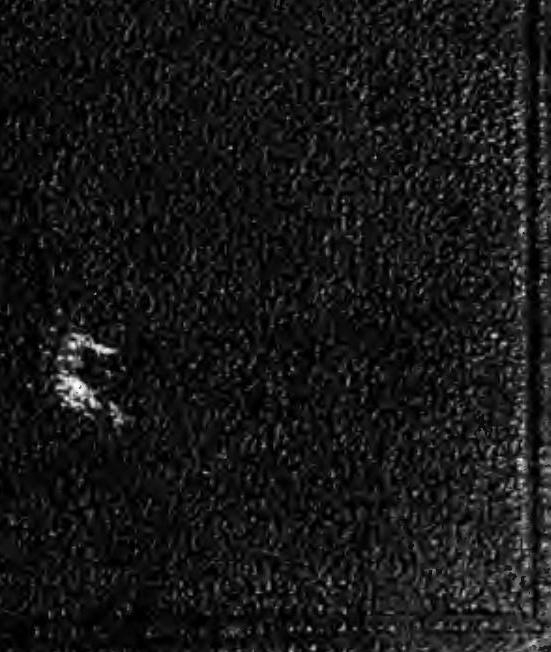




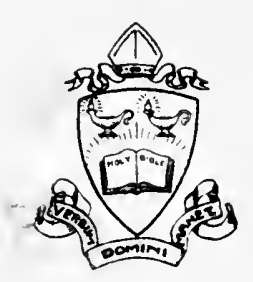

LIBRARY

㫜yrlifte

TORONTO

Shelf No.. BT 301 S7
26

Register No ...10530

$\operatorname{may} 30.08$

45177897 



$$
\begin{aligned}
& \therefore \text { 称 } \\
& \text { a } \quad \cdots \quad \therefore
\end{aligned}
$$

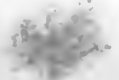

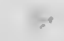

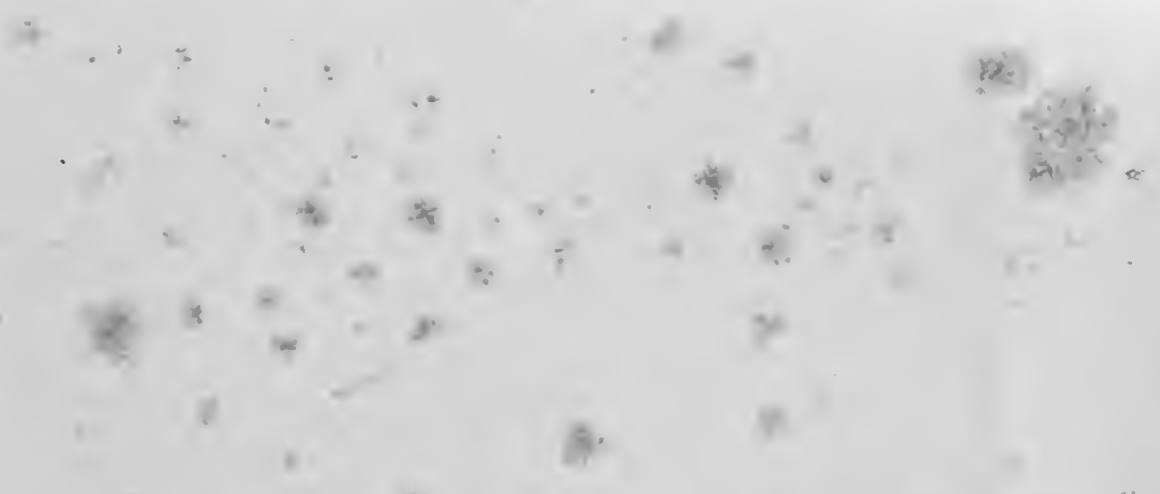

$$
\begin{aligned}
& x^{4}=0 .
\end{aligned}
$$

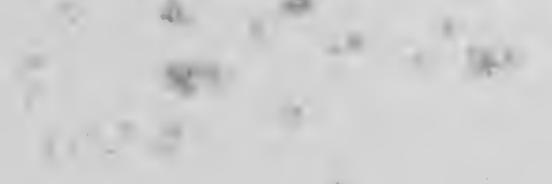

$$
\begin{aligned}
& +\cdots+2 \\
& =x
\end{aligned}
$$




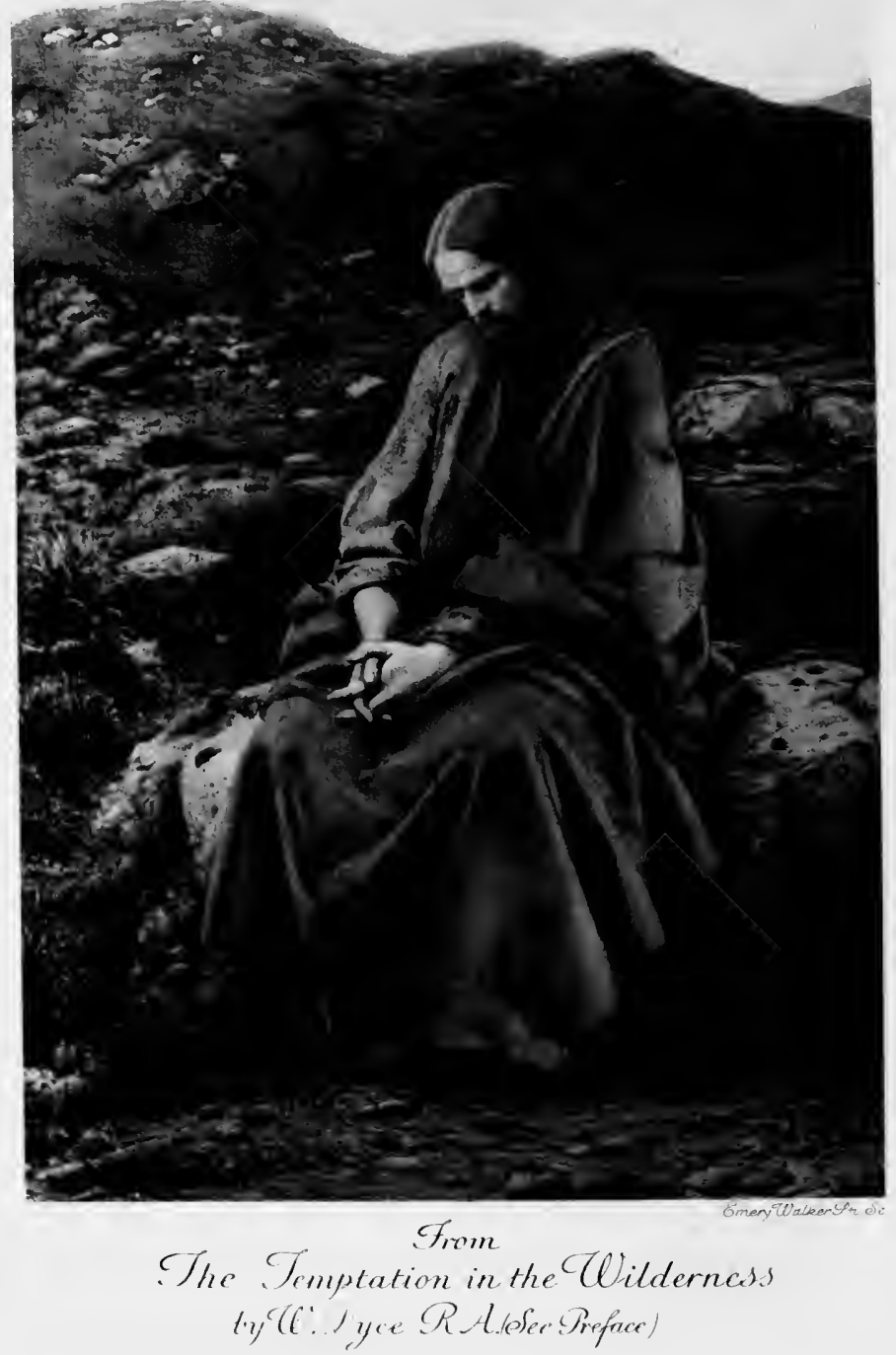




\title{
THE LIFE OF CHRIST
}

\section{IN}

\section{RECENT RESEARCH}

BY

\author{
WILLIAM SANDAY, D.D., LL.D., LitT.D.
}

LADY MARGARET PROFFSSOR, AND CANON OF CHRIST CHURCH, OXFORD

ION, FELLOW OF EXETER COLLEGE; FELLOW OF THE BRITISH ACADEMY

CHAPLAIN IN ORDINARY TO THE KING

OXFORD

AT THE CLARENDON PRESS

1907 
HENRY FROWDE, M.A.

PUBLISHER TO THE UNIVERSITY OF OXFORD LONDON, EDINBURGH

NEW YORK AND TORONTO 


\section{PREFACE}

THE present volume is composite in its origin; and yet, although it was something of an afterthought to print the papers of which it is composed together, they have a considerable degree of unity both of time and purpose. All but one have been written within very little more than a year; and in several cases, as will be readily seen, one has grown out of another. The nucleus of the volume is formed by four lectures delivered in response to an invitation from Cambridge. They had also been rehearsed at Oxford; and the opportunity has been taken to add to them two supplementary lectures given here in the early summer of this year. Almost at the same time with the invitation from Cambridge I received another to lecture at the Church House; and this lecture appears as No. I of the present series ('The Symbolism of the Bible'), the idea in my mind being that some conception of the extent and nature of Biblical Symbolism would be helpful in connexion with the other lectures. It fell to my lot to preach before the University in February last, and the substance of that sermon appears under the title 
'Miracles'. It was still more of an afterthought to reprint at the end of the volume reviews of two recent books by Dr. Du Bose, and with them an article on Dr. Moberly's Atonemant and Personality. Unintentionally, and in the first instance almost unconsciously, these three reviews fell into a kind of connected chain, and as they have a distinct bearing on the main subject though approaching it from a different side, it is convenient to myself, and may be to some others, to have them together. At the last moment I have decided to throw in as an Appendix a sermon on Angels, written for the Chapel Royal on Michaelmas Day. I do this, both because it furnishes another direct illustration of a leading principle that has become clearer to me as the book proceeded and also because the subject is one that has caused me some perplexity, though it now seems to work out satisfactorily.

It would be idle for me to attempt to disguise the fact that the collection as a whole reflects a part of the process of self-education for the larger task that I have undertaken, and to which reference has been made in previous books (Sacred Sites of the Gospels, 1903; Outlines of the Life of Christ, 1905; The Criticism of the Fourth Gospel, 1906). If the criticism is raised that this is not an ideal mode of procedure, the only defence I can make is that I know that it 


\section{Preface}

is not ideal. My object is to clo the best I can with such resources as I have; and under these conditions I have no doubt that tentative methods are conducive to the end in view. I find it helpful to be allowed to make studies on the way, that can be exposed to criticism and so to correction. And I excuse myself partly by the thought that what is good for the single mind may be to some extent good also for the greneral mind. The problems of the present day are so large and so important that they are not to be handled à coup sîr all at once. It ought to be possible to be tentative without being either rash or crude; but whether I have succeeded in that attempt I cannot tell.

There is one special obligation that I have to acknowledge. I had occasion (on p. 29) to refer to a picture of the Temptation of our Lord, as expressing what may be called the modern conception of that event in contrast to the ancient or mediaeval. It really seemed to do more than this: it seemed to me-I do not know whether it will to others, on such matters every one has his own icleas-to bring out more satisfactorily than any other representation with which I am acquainted, either by brush or pen, the effort that the modern mind is making to embody its conception as a whole. The painter was W. Dyce, R.A. (1806-1864), who may be described as one of the 
first pre-Raphaelites. His easel pictures are not very common-he was highly accomplished in a number of ways, and his time was taken up both with the theory and the organization of Art in this country-though there is one other beautiful example of his treatment of sacred subjects, besides a landscape, in the Tate Gallery. The picture of which I have been speaking is in a collection which belonged to Mr. James Henry Stock, of White Hall, Tarporley, some time member for the Walton Division of Liverpool; and the owner most kindly and readily acceded to my request to be allowed to have a photograph taken of it, and to include it in my book. I greatly regret to say that Mr. Stock died after a short illness while the book was passing through the press. I am indebted for the photograph to the skill of Mr. Franz Hanfstaengl.

The three reviews have all appeared in The Expositor, and the two later also in the New York Churchman; and I have to thank the editors of those periodicals for their kind permission to reprint them. I am also once more indebted to my good friend Dr. Lock for his kindness in reading the proofs and giving me the benefit of his criticisms and suggestions.

OxFord, August, 1907. 


\section{CONTENTS}

I. Preliminary.

I. The Symbolism of the Bible .

II. Cambridge Lectures.

II. Twenty Years of Research . . . . . 37

III. " " " $\quad$ (continued) . . . 65

IV. Survey and Criticism of Current Views . . . 90

V. The Deity of our Lord Jesus Christ as expressed in the Gospels . . . . . . . IIg

III. EPILOGUE.

VI. The Most Recent Literature . . . . . I 45

VII. ", ", " (continued) . . . I75

IV. MiRACLES.

VIII. Miracles . . . . . . . . 203

V. The Higher Significance of the Person and WORK OF CHRIST.

IX. 'Atonement and Personality' . . . . . 229

$\mathrm{X}$. 'The Gospel in the Gospels' . . . . . 257

XI. 'The Gospel according to St. Paul' . . . $28 \mathbf{I}$

Appendix.

A Sermon on Angels . . . . . . . . $3^{1} 5$

INDEX $. \quad . \quad . \quad . \quad . \quad \cdot \quad \cdot \quad \cdot \quad 3^{25}$

\section{ILLUSTRATIONS.}

From 'The Temptation in the Wilderness,' by W'. Dyce, R.A.

frontispiece

'The Temptation in the Wilderness'. . Uetwien pp. 28, 29 



\section{PRELIMINARY}

I. THE SYMBOLISM OF TIIE BIBLE 



\section{I}

THE SYMBOLISM OF THE BIBLE

WE are all familiar with the fact that symbolism is used very freely in the Bible; but I am not sure that we realize either the extent to which it permeates the whole volume from end to end, or how important a factor it is, especially in all those problems which have to do with the harmonizing of ancient and modern, of old and new. It is just because these problems are very much upon us at the present time, and because it is more and more impressed upon me that the use of symbolism has a great deal to do with them, that I have been led to choose this subject for my lecture. The way in which I propose to treat it is to attempt a rough classification of the different kinds of symbolism. My hope is, not only that by thus breaking up the subject into its parts we may be helped to form a more adequate conception of its magnitude, but that also by concentrating our attention upon different aspects of it in turn, we may obtain a better understanding of its true nature.

Before going further, I must try to define what we mean by symbolism. Symbolism, I think it may be said, is indirect description; in other words, it is description or expression by a system of equivalents, in which 
the terms or media employed do not at once call up the features of the object, but rather suggest them by calling up the features of some other object like that which it is sought to describe, or which is treated as like it, and for the moment is taken to stand for it.

It will be obvious that symbolism is specially in place when it is used to describe that which it is difficult or impossible to describe directly; such as the nature of God or of spiritual things, of which the mind cannot form any picture as they really are, but can at most suggest them.

We shall also see, by adopting the definition of symbolism as 'indirect description', why it is that the use of symbols forms such a characteristic difference between the ancient and the modern. The great enlargement of our vocabulary, the multiplication of abstract ideas, and generally the growth of a scientific habit of mind, impel us to have recourse to direct description, where the ancients would have used indirect. Our processes are analytic, where theirs were poetic and constructive.

\section{The Symbolical Actions of the Prophets}

We will begin with a class of symbols that is not only very clear and easily grasped in itself, but that also I think may be said to place us at the Biblical point of view in regard to the use of symbols. The class I mean embraces a number of actions specially characteristic of the prophets, which they are represented as carrying out by express divine command, in 
order to bring home to the people in the most palpable and forcible manner the particular truth or message which they are commissioned to declare.

The first instance of this kind is when Ahijah the Shilonite takes Jeroboam aside, and tears up the new garment that he has put on for the occasion into twelve pieces, of which he gives ten to Jeroboam, in token that God would give him ten of the twelve tribes of Israel to form a separate kingdom, while leaving to Rehoboam only two (I Kings xi. 29-32).

The next example is not less instructive because it is supplied by one of those who are called 'false prophets', or prophets at best of a lower order, with an inferior degree of insight and penetration. You will remember how, before the fatal battle of Ramothgilead, Zedekiah the son of Chenaanah made for himself horns of iron, to show how the Syrians would be pushed until they were consumed (I Kings xxii. I1).

The prophet Isaiah walks for three years naked (i.e. without his upper garment) and barefoot, to represent, in a way that could not be mistaken, the captivity of Egypt and Ethiopia, the two powers in which king and people were inclined to trust for support against Assyria : so far from rendering support to others, these powers would be carried away captive themselves in a plight like that of the prophet (Isa. xx. I-6). W'e can understand that an action like this, continued for the space of three years, would drive home the prophet's words in a way that speech alone could never have done.

All this time there was a strong party in favour of 
the Egyptian alliance; but with this impressive warning staring them constantly in the face, they did not dare to give effect to their policy.

In the Book of Jeremiah there are a number of examples, illustrating in different ways the destruction of city and kingdom: for instance, the linen girdle which is soaked in water and spoilt (Jer. xiii. I-I I), the earthen bottle which is broken to pieces at Topheth (ch. xix), the yoke of wood which the prophet wears upon his neck, which is broken by Hananiah the false prophet and then replaced by a yoke of iron (chaps. xxvii, xxviii).

Again, Ezek. iv, $v$ contain a series of signs representing to the Jews in exile the siege of Jerusalem. Some of these actions are so elaborate that the question has been raised whether they can have been carried out quite literally. For instance, in iv. $3^{-1} 7$ the prophet lies on one side with his limbs bound in a constrained and painful position, according to one reading for 390 days, and according to another (which is more probable) for 190. It is possible that there may have been some further symbol by which the repetition of the act was conveyed; but I incline to think that he really did what is described. The Hebrew prophet had something in common with the Indian fakir.

I need not pursue the examples further. It is one of the points of close resemblance between the prophets of the New Testament and those of the Old that, in Acts xxi. I I, Agabus takes St. Paul's girdle and binds himself with it in token that St. Paul himself was to be bound. Here, too, we can see how effective the act 


\section{The Symbolism of the Bible}

would be, and how it would impress the spectators more than simple speech.

The examples given so far are all of voluntary, deliberate acts on the part of the prophets; but there are other cases where the symbolical character is impressed upon the action after the event, as (e.g.) in Jer. xxxii. 6-15, 25, 42-4. But the most conspicuous instance of this ex post facto symbolism is no cloubt the story of the prophet Hosea and his unfaithful wife, Gomer, which the prophet turns into an appeal to the evil and adulterous generation in which he lives. The death of Ezekiel's wife, with its mingled stoicism and pathos, is another instance of a like kind (Ezek. xxiv. 1 5-24).

\section{Symbolical Visions}

By the side of the symbolical actions of the prophets it is natural to place the prophetic visions.

In the Pentateuch we have as a rule dreams rather than visions: e.g. Gen. xx. 3 (Abimelech); xxviii. (Bethel); [xxxii, Peniel $\left.{ }^{~}\right]$; xxxvii, $x l, x$ li (Joseph). The vision is, I suppose, really an extension of the dream, but with a greater degree of coherence and plastic elaboration. Prophetic visions, like those of Isaiah vi and Ezekiel i, are the highest phenomena of the kind.

We do not forget that the dreams which occur so plentifully in the book of Genesis are more representative of the time at which they were committed to writing than of the time to which they are referred as

1 Perhaps this should rather come under the head of 'symbolic history'. 
history. And yet they certainly belong to the earliest portions of the book; and they are really characteristic of the most primitive stage of Israel's religion. If we believe, as I think we must, in a divine employment of human faculties and natural human processes for the purpose of revelation, then I think that we shall see in these dreams, which are made to be the vehicles of religious truth or divine command, an instrument of this kind.

Still more may we say this of the prophetic visions. The dream as well as the vision is really the expression of the inner man. Only a religious man who, in the beautiful old Biblical phrase, habitually 'walked with God', was capable of receiving revelation through dream or vision. ${ }^{1}$

A vision such as that which embodies the 'call' of Isaiah is not one in which the human faculties are wholly laid asleep. The scenery of the vision is taken from Solomon's temple. We can well believe that the prophet was actually worshipping there when the trance that he has described for us came over him. He was conscious of holding as it were a dialogue with the Almighty. He understands what is said to him, and at first resists the commission imposed upon him, but his scruples are overcome by what he recognizes as an inspiration from on high. This experience is the foundation of his whole prophetic career.

In the case of Ezekiel there is probably a more deliberate and conscious use of imagery. The central

${ }^{1}$ On the psychology of the prophetic visions see especially Driver, Minor Prophets (in the Century Bible), pp. $176 \mathrm{f}$. 
conception is that of the divine glory and majesty; but there is also brought out the ceaseless activity of God's providence in the government of the world and in the ordering of events. I need not say that every detail of the picture is symbolical.

The prophets with whom visions are most prominent are Jeremiah, Ezekiel, and Zechariah: e.g. Jer. i. I 3 f. (the Almond Tree), i 3 f. (the Caldron), xxiv (the Baskets), Ezek. viii-xi (mingled continuations of the first vision and scenes of what is going on at Jerusalem), xxxvii (the Valley of Dry Bones); Zech. i (the Horsemen and the Horns and Smiths), ii (the Measuring-line), iii (the Acquittal of Joshua), iv (the Candlestick and the Olive Trees), v (the Roll and the Woman), vii (the Chariots).

\section{Symbolical Represcntation of the Godhead}

The prophetic visions of which we have just been speaking belong, of course, to the highest grades of Israel's religion. There were naturally other more naive representations current among the people, and at earlier or lower stages in the history of the religion.

We are not surprised to find that in the early books of the Bible, where dealings take place between God and man, the Godhead is represented under human form. Man was himself the noblest being with which he was acquainted; and therefore, in conceiving of a Being still nobler, he necessarily started from his own self-consciousness; he began by magnifying his own qualities, and only by degrees did he learn, not only to magnify, but to discriminate between them. The first 
step in safeguarding the spirituality of God is to ascribe His actions, not to Jahveh Himself but to $\mathrm{His}$ Angel. The nearer relations-those in which the converse of God and man is more immediate-are referred to the Angel, the more distant to Jahveh Himself. Thus, for instance, in the story of Hagar we read: 'And the Angel of the Lord said unto her, Behold, thou art with child, and shalt bear a son; and shalt call his name Ishmael, because the Lord hath heard thy affliction' (Gen. xvi. I I) : it is the visible Angel who speaks, but the Lord (Jahveh) in heaven who has heard. ${ }^{1}$

Besides these representations of the divine under the similitude of the human, there is a group of natural phenomena that in Hebrew literature is specially associated with God's presence. These are phenomena of earthquake and storm, of which there are many vivid examples in the Psalter (e.g. Pss. xviii. 7-I5, xxix. 3-9, lxxvii. 16-19, xcvii. 2-5). I will quote a verse or two of the first great passage in the familiar Prayer-Book version, just to recall it to your minds :

He made darkness $H$ is secret place, $H$ is pavilion round about $\mathrm{Him}$ with dark water, and thick clouds to cover Him. At the brightness of $\mathrm{His}$ presence $\mathrm{His}$ clouds removed [more literally, there passed through His thick clouds-passed through, and came down] hailstones and coals of fire. The Lord also thundered out of heaven, and the Highest gave His thunder, hailstones and coals of fire.

The brilliance of lightning, appearing from time to time, suggested to the Hebrew that it was not what

1 On this see Kautzsch in Hastings, D. B., extra vol., p. $63^{8}$. 


\section{The Symbolism of the Bible}

we know it to be, an electric stream or flash darting across the landscape, but rather a momentary glimpse of brightness concealed behind the storm-cloud, and enveloped in the cloud, but now and then seen through rents in it. The next step was to compare this brightness, dazzling and blinding as it was, to the glory of God, the splendour of which could not be enclured by any mortal eye if it were seen for more than a passing moment. Then further there were combined with this the other phenomena of tempest-the rushing wind, earthquake, great tidal waves, torrents of rain and hail-all expressive of irresistible power, and, to crown all, thunder, which was naturally regarded as a voice speaking out of the cloud. ${ }^{1}$

The primitive Hebrew, when he saw these things, associated directly with them the presence of God. We must remember that as yet he had not learnt to analyse the processes of his own mind; he had not learnt to distinguish between fact and figure; it was just an instinctive physical apprehension, and nothing more. He was like the Indian

whose untutored mind

Sees God in clouds, and hears $\mathrm{Him}$ in the wind.

If he had been asked, he would have said that it was God whom he saw and heard. In the light of subsequent history we can understand that what he wanted to say, and really intended to say, if he could have put his thought into words, was that these things of which he was aware through the senses were signs or symbols

${ }^{1}$ Compare Illingworth, Personality, Human and Divine, pp. $7 \mathrm{f}$. 
of God's presence. The Hebrew was never really a materialist, though he might appear to be one. It was only the imperfection of language and psychological analysis. We can watch the process by which these were gradually improved and perfected. And it is but justice to observe that the process is strictly continuous, and therefore to explain its beginning by its endto give the thinker credit for meaning to say from the first what he ultimately succeeds in saying.

\section{The Symbolism of Worship}

Really the whole system of worship under the Old Covenant was symbolical : in other words, it was the expression of spiritual ideas through outward visible and material forms. The ideas that underlay the forms might be more or less unconscious : but they were essentially ideas, and spiritual ideas. Again, we have to remember that we are dealing with a people that had no advanced psychology, that was not in the habit of analysing its own processes of thought, and therefore which had not the means of distinguishing as we can between symbol and reality. But we can see, looking back, that the intention was right, that the distinction was being made with increasing clearness; the horror of idolatry that came to be so characteristic of the Jews was only the climax of a long development.

The history of Worship in Israel is the history of the gradual construction of a system framed on logical lines. Of course the fundamental principles are two: that Jahveh is Israel's God, and that Israel is Jahveh's 


\section{The Symbolism of the Bible}

people. As the transcendence of God came to be more and more understood, it was felt that everything in Israel really belonged to $\mathrm{Him}$. At the same time, as a practical compromise, it was held that the direct consecration of a part satisfied the condition of the real consecration of the whole.

Thus the land was holy: it was Jahveh's possession. But the one city that God had chosen for His dwelling place was Jerusalem; and within Jerusalem the Temple; and within the Temple the Holy Place, and still more the Holy of Holies.

In like manner, all times were really holy; but the Sabbath was set apart within the week, and the Sabbatical year in the cycle of years; and the year of Jubilee when this cycle had seven times run its round. The practice was naturally less strict than the theory. If the cancelling of contracts and the reversion of property in the year of Jubilee had been carried out, society must have been utterly disorganized. ${ }^{1}$

Then again every person, at least every Israelite, was, strictly speaking, dedicated to God. But this dedication of the whole people was first commuted for that of the firstborn, and then for the consecration of the priests to minister specially before the Lord. And there are other special organs of Jahveh, such as the prophets and the king.

This is the complete system, as we now find it set forth in the Pentateuch. But it had not been drawn out in all its logical ramifications until after the Return from the Exile. It must not, however, be thought that

${ }^{1}$ Kautzsch, op. cit., pp. $718 \mathrm{ff}$. 
because the logical system was incomplete, therefore the earlier stages were really less dominated by ideas. Doubtless thought dwelt more upon material forms; but that was only because primitive Israel was less advanced in its powers of rational analysis and expression.

There never was a time when worship did not take the form of sacrifice; and from the very first sacrifice was expressive of ideas. The two ideas that we can trace furthest are those of the gift and of sacramental communion. At first these ideas took the form of a dim instinct; but by degrees the principle which lay behind religious usage became more and more conscious and explicit. The impulse to propitiate or to show gratitude by gifts is deep rooted in human nature. On the other hand, as far back as we can go, the common meal was significant. That which was food for men was regarded also as food for God, and was offered to the Deity as such. Of that which remained over when a portion of the victim had been burnt upon the altar, a sacrificial meal was made, of which the worshipper also partook, thus sharing with the Deity and receiving a communication of His divine qualities.

Another primitive rite was that followed in the ratification of a covenant. The sacrificial victim or victims were cut in half, and the portions placed opposite to each other with a sort of lane between : and the parties to the covenant passed along this lane, thereby invoking the fate of the animal upon themselves-might they be so cut in pieces, if they broke the covenant. In Gen. xv the covenant which God 
makes with Abraham is represented as confirmed by ceremonies such as these. The furnace and the flaming torch which after sundown pass between the pieces of the sacrifice, symbolize the presence of God Himself, who takes upon Himself an obligation like that contracted in a covenant between men.

The great covenant at Sinai is different in its character. Here the leading idea is that of the communion established between God and Israel. The medium of communion is the sacrificial blood, representing the life. Half of it is sprinkled upon the altar and upon the sacred vessels signifying the divine side of the covenant, and the other half upon the people, signifying the human side. Thus the whole people enters into a close covenant relation with God (see Exod. xxiv. 5, 6, 8).

These are just examples which may help to show how deeply the whole cultus and everything connected with it was saturated with symbolism.

\section{Historical Symbolism}

Where the Hebrew historian is writing of events that were still fresh in men's memory, and where he is drawing upon good contemporary sources, he is an excellent narrator. There is no redundance of language, no straining after effect, no obscurity of detail ; and yet the human feeling of the story, the pathos and the tragedy, come out of themselves in a way that is strangely moving. It is like the simple, dignified, reserved, and yet expressive speech that seems natural to the East, 
and that in the Bible always has the religious sense behind it. But the first book of the Bible goes back to a period beyond the reach of any continuous tradition. The resources of modern science, of geology and astronomy, were not then available for recovering the records of the past. Our forefathers did not hesitate to suppose that the gap was filled by a preternatural conveyance of knowledge which they included in their definition of Inspiration ; but we have learnt to think of Inspiration differently. The more verifiable examples of its working are of another kind. We may believe, as we do fully believe, that the Divine Spirit has been at work in these early chapters of Genesis without assuming any anticipation of the scientific discoveries of modern times. We should not be wrong in calling the cosmogony of Genesis a symbolical representation of the facts. A like description, indeed, on a lower plane might be given of the Babylonian cosmogony: and yet the difference between the two is very great; so great, that to call it the difference between a true and a false religion, though somewhat crude, is hardly an exaggeration. And the measure of the difference is also the measure of what we mean when we claim a special inspiration for the Bible.

The cosmogony of the book of Genesis, I cannot help thinking, has had rather hard measure at the hands of criticism. Its sublime features have indeed been pointed out; but along with this there has gone a certain severity of judgement from the point of view of modern science. The application of such a point of view is really a survival from the days when the 
inspiration of the Bible was identified with verbal infallibility. Scholars have been compelled to point out, in the interest of truth, that this definition will not hold; and in the course of their argument they have appealed to modern science as furnishing corrections of fact. But I cannot help hoping that the time has come when such corrections will no longer be thought necessary; when, in other words, it will be assumed from the outset that the representations in Gen. i-iii. are symbolical, and that they were never intended to be literal. These are perhaps the nearest words we can use; and yet we do well to remind ourselves that they are our words, and not the writer's. It is not that he had two clearly recognized modes of expression before him, and that he deliberately chose the one and refused the other. His mental effort was towards truth, but not towards truth in our sense of strict scientific correspondence with material facts. His mind moved along the only lines that were possible to it, the lines of pictorial imagination. And upon those lines it is wonderful how much he has accomplished. When once we agree to regard his pictures as symbols, we are free to admire not only their sublimity and essential truth from the point of view of religion, but also the remarkable aptness of their form for the purpose for which they were designed. To this day, if we had to give an account of the process of creation to a child, or to an adult at a lower stage of culture than our own, and who in particular was ignorant of the first principles of natural science, could we easily do so better than in the language of Genesis? Surely 
this is the right kind of question to put to ourselves, and not any other.

The early chapters of Genesis are not the only portion of the Pentateuchal history to which I think that we may rightly apply the epithet 'symbolical'. Indeed I suspect that the greater part of the Pentateuch would be rightly so described in greater or less degree. The narrative of the Pentateuch culminates in two great events, the Exodus from Egypt and the giving of the Law from Mount Sinai. What are we to say of these? Are they historical in the sense in which the Second Book of Samuel is historical? I think we may say that they are not. If we accept-as I for one feel constrained to accept, at least in broad outline-the critical theory now so widely held as to the composition of the Pentateuch, then there is a long interval, an interval of some four centuries or more, between the events and the main portions of the record as we now have it. In such a case we should expect to happen just what we find has happened. There is an element of folklore, of oral tradition insufficiently checked by writing. The imagination has been at work.

If we compare, for instance, the narrative of the Ten Plagues with the narrative of the Revolt of Absalom, we shall feel the difference. The one is nature itself, with all the flexibility and easy sequence that we associate with nature. The other is constructed upon a scheme which is so symmetrical that we cannot help seeing that it is really artificial. I do not mean artificial in the sense that the writer, with no materials before him, sat down consciously and deliberately to 


\section{The Symbolism of the Bible}

invent them in the form they now have; but I mean that, as the story passed from mouth to mouth, it gradually and almost imperceptibly assumed its present shape.

In like manner as to the giving of the Law from Mount Sinai.

First of all, I conceive that Moses, when he gave Israel the judgements and decisions that formed the first nucleus of the Pentateuchal Code, did so solemnly in God's name, with something very like the prophetic formula, 'Thus saith the Lord,' and with the full assurance that he really was commissioned to speak by and for the Almighty.

In this way the little nucleus of funclamental laws and institutions left by Moses came to be regardedand not wrongly regarded-as so much divine legislation. And then the imagination played round the idea of divine legislation, and invested it with what seemed more adequate circumstances of solemnity and sanctity. We have seen how the thunderstorm was considered to be a special manifestation of God's presence, and the thunder was God's voice. Hence, when the Decalogue is prefaced, 'God spake these words and said,' nothing could be more natural than that the words should be represented as coming out of the storm, with 'thunders and lightnings, and a thick cloud upon the mount, and the voice of a trumpet exceeding loud' (Exod. xix. 16). And again when we remember how, in the covenant of God with Abraham, the Divine presence is represented by ' a smoking furnace and a flaming torch that passed between' the pieces of the victims, we are not surprised 
when we read that 'Mount Sinai was altogether on smoke, because the Lord descended upon it in fire; and the smoke thereof ascended as the smoke of a furnace, and the whole mount quaked greatly' (ver. I8). These are just poetic accessories, emblematic of the central fact that the words proceeded from God. The literal truth was that God spoke to the heart of Moses: the poetic truth was that He spoke in thunder and lightning from the crest of Sinai.

This, I think, may be aptly described as Historical Symbolism, or Symbolical History.

\section{Apocalyptic Symbolism}

There is one apocalypse in the Old Testament-the book of Daniel; and there is one apocalypse in the New Testament-the Revelation of St. John; and, roughly speaking, between about the middle of the second century B. C. and the middle of the second century A. D., there are a number of Jewish apocalypses which have not been received into the Canon, though one of them, that called 2 Esdras (4 Ezra), has a place in the Old Testament Apocrypha.

It is of the very essence of these apocalyptic books that they are symbolical. The two leading apocalypses, the book of Daniel and the Revelation of St. John, may be said to be doubly symbolical. That part of them which is not taken up with apocalyptic symbolism is written in the spirit of historical symbolism. This, for instance, holds good of the historical portion of the book of Daniel, and to some extent of the 


\section{The Symbolism of the Bible}

Letters to the Seven Churches in the Revelation of St. John. But the most characteristic part of both books is the apocalyptic visions.

These visions, though they are modelled upon the visions in the older prophets, probably differ from them-or at least from the earlier of them-in that they are not so much a record of real visions as literary compositions. The apocalyptic writers had their minds full of the old prophetic imagery, and in their hands it assumed new shapes, and was applied to new purposes.

In the book of Daniel the most important visions are those in chaps. ii, vii. In ch. ii Nebuchadnezzar is represented as dreaming that he saw a great image made up of different materials, gold, silver, brass, iron, and clay. This image is struck by a stone cut from a rock without hands and reduced to powder which the wind carries away, while the stone becomes a mountain and fills the whole earth. The different materials, gold, silver, \&c., represent symbolically a succession of empires, the Babylonian, Median, Persian, and the Greek Empire founded by Alexander the Great. This last is partly of iron and partly of clay, as being weakened by division among the successors of Alexander, such as the Seleucidae in Syria and the Ptolemies in Egypt. The stone cut out of a rock without hands is the kingdom of the Messiah which destroys and supersedes the rest.

The vision in ch. vii is similar in its significance. There we have the same four kingdoms in the guise of beasts of prey which are brought before the Divine 
judgement-seat. The last, and worst, of the beasts is slain, and the others are deposed, while a fifth figure, in the form of a man, absorbs their kingdoms into his own, which is eternal. This eternal kingdom is in the first instance that of the regenerate Israel (Dan. vii. I8), but in the time of our Lord it has become the kingdom of the personal Messiah. We shall have occasion to follow the history of this conception more closely in a later lecture.

The Revelation of St. John is even more entirely made up of symbols. It is an imaginative presentation of a series of supernatural events, which usher in the end of the age and a new world.

The historical background of the book is the Roman Empire, concentrated in the person of the emperor and in the city of Rome, and the worship of the emperor, which from Augustus onwards had been more or less encouraged but in the reign of Domitian was enforced by the State. This enforcement, in the case of Christians, necessarily involved persecution. And the whole soul of the prophet-the book throughout is called a 'prophecy'-rose up in passionate indignation against this idolatrous and (as it seemed to him) blasphemous worship and the tyranny with which it was allied. He paints both in lurid colours under the figures of the two Beasts, who are the instruments of the Dragon or Satan. He has also a grandiose picture of Rome, under the pseudonym of Babylon, and exults over her impending downfall, which he works into his anticipations of the end of the world regarded as near at hand. 


\section{The Symbolism of the Bible}

Now I suppose the chief problem raised by the book is how it is that this prophecy has been so imperfectly fulfilled. The prophet speaks in tones of intense conviction. We know how solemnly at the end of his book he adjures those who read or copy it not to tamper with his prophecy either by addition or subtraction, but to leave it exactly as it was written (Rev. xxii. I8, 19). Almost in the same breath he insists on the imminence of the end, repeating for the third time the announcement, 'Behold, I come quickly' (vv. 7, I2, 20). And yet the Lord has not come; Babylon the Great has not fallen and become a dwelling for wild beasts. Rome still stands; and if the Roman Empire has perished, it was by no sudden divine catastrophe, but by slow exhaustion and decay.

It is the problem of all eschatology. We observe that in this case the disciple has neglected, or seems to have neglected, the Master's warning that it was not even for the most privileged to know the times or the seasons which the Father had reserved under His own supreme control.

If we are to explain the prophet's language on this side, it can only be by invoking the principle of symbolism-which, as we have seen, is of the very essence of all apocalypse-and by saying that he describes in terms of time that which is not really a question of time but of certainty in the nature of things. ${ }^{1}$ God and Christ must reign; the powers of evil must be overthrown. And, as a matter of fact,

1 This is admirably expressed by Sir W. MI. Ramsay, Letters of the Seren Churches, pp. I I 2 f. (cf. J. T.S. July, I907, p. 496). 
at that very moment when the prophet wrote, a great step forward was being taken-the greatest step in the history of the world-towards that final consummation.

But really the most illuminating thing in regard to the whole class of questions raised by the Apocalypse is an incident and saying in the Life of our Lord. When St. Luke represents the Seventy as returning from their mission, they eagerly ( $\left.\mu \epsilon \tau \grave{\alpha} \chi^{\alpha \rho \alpha \hat{s}}\right)$ tell their Master that they found even demons yield to them in His name. Thereupon He says : 'I beheld Satan fall as lightning from heaven' (Luke x. I 7, I 8). Really the Apocalypse is just an expansion of that. There is, as it were, a heavenly counterpart of the struggle which goes on upon earth. Vast mysterious forces are arrayed against each other in what St. Paul calls

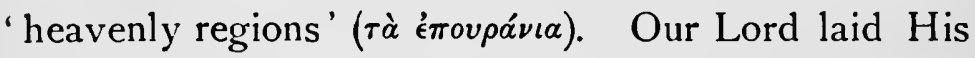
finger on the crisis in this battle. Those few successful exorcisms meant immeasurably more than the missioners who performed them could imagine. They meant that the crisis in that age-long conflict had passed, or was passing, and that the power of Satan was really broken.

\section{The Symbolical Language of Christ}

In the last illustration I have been anticipating, and have really encroached upon the next-and last-stage in the evolution of my subject. The uses of symbolism of which we have so far been speaking have been diverse in their character-some comparatively simple and straightforward, others difficult. But the chief 
impression that I have desired to bring home to you is of the immense range which symbolism covers in the Bible, and of the extent to which it has to be reckoned with at every turn. This is, I conceive, a necessary preliminary to the consideration of what will be felt to be the most important part of my subject, the use of symbolism by our Lord Himself.

Here, again, some things are evident at first sight. The long list of Parables shows how naturally (if we may say so) the teaching of our Lord assumed a symbolical form. There were, of course, some precedents in the Old Testament, such as the parable of Jotham and Nathan's address to David. We have also quite recently had a collection of Parables put together from the Talmud: Fiebig, Altjiidische Gleichnisse u. die Gleichnisse Fesu (Tübingen u. Leipzig, 1904).

You will remember the account that is given of the object of teaching by parable in St. Mark, ch. iv. I I, I 2, and parallels: 'Unto you is given the my'stery of the kingdom of God: but unto them that are without, all things are done in parables: that seeing they may see, and not perceive; and hearing they may hear, and not understand,' \&c. Many critics have taken exception to this, especially-and very characteristicallyJülicher, and a number of others following in his wake, on the ground that the Parables of our Lord are too limpid in their clearness to have anything esoteric about them or to be used in any sense for purposes of concealment. Indeed, it was becoming almost a commonplace in certain circles that the whole of this passagre might be assumed to be unhistorical. 
But now it is beginning to be seen that, after all, the Kingdom of heaven had its mysteries, some of which were appropriately expressed in the form of parables, and so at once partly concealed and partly revealed. The fact that to this day opinions diverge so widely about the nature of the Kingdom should have been enough to guard the Evangelists from the charge of perversity in suggesting that there was anything in the Parables that could not be understood at once by the meanest capacity.

And yet, broadly speaking, it is true that many of the Parables are readily intelligible, and that they appeal to the poor and simple even more strongly than to the learned. Our Lord spoke very much in the vernacular, and the common people heard Him gladly. He spoke, as the people themselves speak, in bold and stronglymarked metaphors. This is part of what Luther meant when he said: 'The words of our Saviour Christ are exceeding powerful: they have hands and feet' (Table Talk, No. lii).

But there was another aspect of our Lord's words that contributed to the same effect. Perhaps it is a little strained to call this a use of symbols. And yet this too may come under the head of 'indirect description', or at least of description that is not meant to be taken too literally. I refer to the frequency with which our Lord has recourse to what might be called 'extreme expressions '. ${ }^{1}$ For instance, when He speaks of plucking out the right eye, or cutting off the right hand (Matt. v. 29, 30); or again when he speaks of faith

${ }^{1}$ Cf. Johannes Weiss in Theol. Literaturzeitung (1895), col. 644. 
removing mountains (Matt. xxi. 21). These are very forcible expressions, the last of which I believe certainly does imply a great command even over external nature; and yet it must not be taken too literally-any more than we are meant to take exactly to the letter the saying about the mote and the beam in the eye (Matt. vii. 4,5 ). It is evident that this strong manner of speech was really characteristic of the popular preaching of our Lord.

But the point to which I most wish to call attention is the remarkable extent to which our Lord accepts, and adapts to His own purposes, a body of symbolism which He found already in existence as part of the common stock of ideas of those among whom He lived and moved. For instance, how remote from the thought of our time, and how full of meaning for the thought of the time at which it was spoken, is the following: 'The unclean spirit, when he is gone out of the man, passeth through waterless places, seeking rest, and findeth it not. Then he saith, I will return into my house whence I came out; and when he is come, he findeth it empty, swept, and garnished. Then goeth he, and taketh with himself seven other spirits more evil than himself, and they enter in and dwell there; and the last state of that man becometh worse than the first' (Matt. xii. 4j-5).

One of the most instructive passages for the purpose I have in view is the account of the Temptation. In this our Lord goes to what may seem great lengths in the use that He makes of the traditional machinery of Judaism. There are three scenes in which the Son 
of God is assailed by the Tempter. We are reminded of that assembly in heaven at the beginning of the book of Job, at which Satan presents himself, and is asked from whence he came, and he replies, 'From going to and fro in the earth, and from walking up and down in it' (Job i. 7). He is then permitted to try what he can do to shake the constancy of Job, just as in the narrative of the Gospels he aims his attempt higher still. The change of place by levitation to the pinnacle of the Temple and the exceeding high mountain recalls to us especially the book of Ezekiel. For instance, in Ezek. viii. 2, 3, a fiery shape appears to the prophet: "And he put forth the form of an hand, and took me by a lock of mine head : and the spirit lifted me up between the earth and the heaven, and brought me in the visions of God to Jerusalem, to the door of the gate of the inner court that looketh toward the north.' This is no doubt the original which suggested that strange statement in the apocryphal Gospel according to the Hebrews, referred to by Origen and Jerome, ' $\mathrm{My}$ mother the Holy Ghost took me by one of my hairs and carried me away to the great mountain Tabor' (Nestle, N. T.Gr. Suppl., p. 77). There are a number of examples in the book of Ezekiel of these celestial journeys (cf. iii. I 2 ; xi. I, 24 ; xxxvii. 1 ; xliii. 5). Ezekiel is by the river Chebar in Mesopotamia, but he is carried by the Spirit to Jerusalem and sees what is going on there.

All this is of the nature of machinery or outside setting. For us the story of the Temptation has a deep spiritual meaning; for us it expresses, if we may 


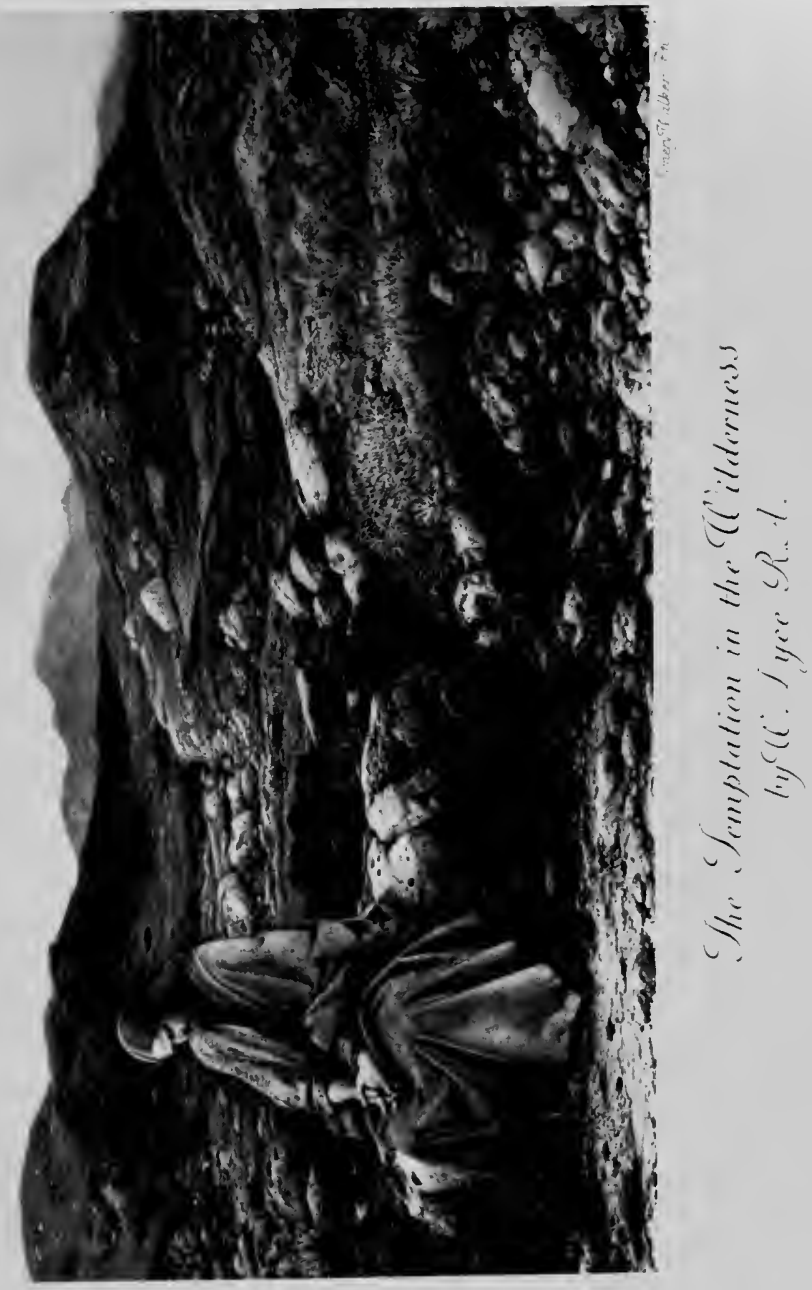



so say, the problem that presented itself to the mind of our Lord at the first outset of His ministry-how $\mathrm{He}$ is to exercise the wonderful endowment of which $\mathrm{He}$ was conscious, how $\mathrm{He}$ is to discharge His Messianic mission.

I am reminded of two pictorial representations of the scene. In 'Tissot's well-known book there is a good deal of careful study in the reproduction of the Temple, but the Tempter is just the conventional fiend, with ram's horns and exaggerated bat's wings. In marked contrast to this is a picture which I saw nearly thirty years ago in a private collection, "The Temptation of Christ in the Wilderness,' by W. Dyce, R.A. All that we see here is a monotonous landscape and a Figure seated upon a stone, with the hands clasped and an expression of intense thought on the beautiful but by no means effeminate features.

The contrast would be still greater, if we took the mediaeval conception as it still survived in Memling and Holbein and Duirer and Luther. Tissot at least makes his outlines vague and shadowy, whereas in the art and thought of the Renaissance and Reformation period they are as sharp and definite as possible. It would, however, be a mistake if we were to insist too much upon this contrast, as though the modern presentation were right and true and the ancient or mediaeval wrong and untrue. Each is really right in its place; they mean fundamentally the same thing, and it is only the symbolical expression that is different.

The story of the Temptation naturally goes with the incident to which I have just referred, the Return 
of the Seventy and our Lord's announcement in connexion with it. The vision of the Fall of Satan was the counterpart or reflection in heaven of the casting out of demons on earth. It meant that Satan was really vanquished, the victory over him virtually won. I said that we might regard the Apocalypse of St. John as an expansion of this idea. And, conversely, I think we may say that our Lord's language distinctly belongs to the apocalyptic scheme.

There are really two remarkable things in the passage just referred to. The first is this-the extent to which our Lord adopts the current apocalyptic language. The phrase about Satan falling from heaven belongs to the same category with those about Satan being bound and cast into the lake of fire; it is essentially apocalyptic and essentially Jewish. To us it seems perhaps at first sight fantastic, and we are surprised that our Lord Jesus Christ, with all His penetrating insight into truth and reality, should condescend to make use of the strange ideas that were current around Him.

That is perhaps our first thought. But then our second thought is, when we look into the matter a little more closely, that after all there is no real incongruity. There is nothing really fantastic in our Lord's meaning. The facts of the situation were, as I said a short time ago, that the disciples came back from their mission reporting that they had found themselves able to heal a few demoniacs. I think there is no doubt whatever that such things did occur. Not only did our Lord Himself heal these unfortunate beings, but it is assumed in the Gospels that even the 
Pharisees and their disciples sometimes healed them ('If I by Beelzebub cast out devils, by whom do your sons cast them out?'). That is the bare fact, the literal fact, that the disciples had performed these cures-a small enough matter, we might think, accomplished in an obscure corner of Palestine. But, small as it is, our Lord sees that it has a cosmic significance. It means nothing less than that this haunting power of temptation and evil, which dogs the steps of humanity wherever it goes, will at last come to an end; its ultimate fate is sealed; the decisive blow has been struck, and the effect will be only a question of time.

Shall we say that such insight as that was unworthy of the Son of God, or that it was possible to any besides Him? The form that His saying takes is simply an example of His use of symbols.

Just one more example of a rather different kind. We are familiar with the biblical view of the mission of John the Baptist. We know that he was to go before the face of the Lord in the spirit and power of Elijah, to prepare for Him an obedient people (Luke i. 17). The history of this designation of the Baptist as Elijah is interesting, and I think important.

To whom do we owe it? To none other than our Lord Himself. I will just rapidly run over the evidence, and then make a few comments upon it. As they were coming down from the Mount of Transfiguration, the disciples asked our Lord, saying, ' The scribes say that Elijah must first come. And He said unto them, Elijah indeed cometh first, and restoreth all things : and how is it written of the Son of Man, that 
He should suffer many things and be set at nought? But I say unto you, that Elijah is come, and they have also done unto him whatsoever they listed, even as it is written of him' (Mark ix. II-I3). St. Matthew in the parallel passage (Matt. xvii. IO-I 3 ) adds, 'Then understood the disciples that $\mathrm{He}$ spake unto them of John the Baptist.' The fundamental document there is the Mark-Gospel. Another passage is what is often called Logian: 'All the prophets and the law prophesied until John. And if ye are willing to receive it, this is Elijah, which is to come. He that hath ears to hear, let him hear' (Matt. xiii. I3-15). There we are expressly told that it was our Lord who gave the name to John. A common opinion was that our Lord Himself was Elijah (Mark vi. I 5 and parallels; comp. Mark viii. 28 and parallels). John himself had no idea that he was Elijah. The Fourth Gospel relates how a deputation came down from Jerusalem to inquire who he was. They asked if he was Elijah; and he answered that he was not (John i. 2 I). I pause for a moment to point out what an authentic touch this is -all the more authentic, because it runs counter to the general Christian tradition.

Here again we have another feature in the apocalyptic scheme. The Jews expected that Elijah would come before the Messiah. They did this on the strength of Mal. iv. 5, 6, 'Behold, I will send you Elijah the prophet before the great and terrible day of the Lord come,' \&c. Here too the Jewish expectation was fantastic and superstitious. As Herod believed that our Lord was John the Baptist actually risen from 


\section{The Symbolism of the Bible}

the dead (Mark vi. 14 and parallels), so they doubtless believed that Elijah would rise from the dead. Our Lord does not adopt this part of the belief. He takes the work of John just as it was, and by what a German writer calls His own 'dogmatic' or authoritative verdict, He pronounces him to be Elijah. He treats him as the Elijah of prophecy. And in doing this $\mathrm{He}$ is quite aware that His verdict is (so to speak) esoteric, that it was one that everybody would not understand: 'If yc are willing to receive it, this is Elijah ... He that hath ears to hear let him hear.'

I do not propose to go further than this. I have given three remarkable, and I think I may say typical, examples of our Lord's use of symbolism. I would invite you to think them over, and to see whether they do not suggest a clue to some other things besides themselves. Two of the three examples belong to the region of apocalyptic. And I am coming to think myself that we shall have to take more account of this region than perhaps we have done. I take some blame to myself for not having perceived what I now seem to perceive before. I do not know that I shall have very much to retract, because I have always wished to speak guardedly on this subject; and yet I confess that a good many things appear to me otherwise than they did.

I must reserve the fuller exposition of these differences for the present. The lecture that I have been giving is intended rather to prepare the way for their discussion. I shall be glad if it should prove to be of 
any service towards that end. But, apart from anything that it may contribute in the way of argument and inference, I hope that it may help to commend a certain attitude of mind.

That attitude, I think, consists mainly in three things :

I. In a spirit of reverence for old ideas, which may perhaps be transcended, but which discharged a very important function in their day;

2. In a spirit of patience which, because those ideas may be transcended, does not at once discard and renounce them, but seeks to extract their full significance ;

3. In an open mind for the real extent of this significance. We have our treasure, perhaps, in earthen vessels, but the vessels are themselves very deserving of study. I would say rather that, for the purpose before us, we should not think of them exactly as earthen, but as made of some finer and more transparent material which permits us to see through to the light within.

I will venture to add that this attitude is not only right for the particular subject in connexion with which it is suggested, but for all that has to do with the history of Christianity, and indeed for all serious study of Religion. 


\section{CAMBRIDGE LECTURES}

II. TWENTY YEARS OF RESEARCII

III. TWENTY YEARS OF RESEARCH (continued)

IV. SURVEY AND CRITICISM OF CURRENT VIEWS

V. THE DEITY OF OUR LORD JESUS CHRIST $A S$ EXPRESSED IN THE GOSPELS 



\section{I}

\section{TWENTY YEARS OF RESEARCII}

THOSE of us who make much use of German tools and who try to acknowledge adequately the debt they incur in doing so run the risk of becoming tedious to their own countrymen. The world is apt to grow weary of hearing Aristides called the Just. And yet, if one is constantly consulting Aristides, that is the least that is his due.

On great problems, and from the point of view of research, it is a secondary merit in a book to be right. I should be far from laying this down as a general rule; but within the particular conditions that I have in view I think it holds good. Within these conditions, I suppose that the greatest merit of all is to deserve to be right. One may be right by accident, or through acquiescing in some one else's opinion that happens to be right. But to deserve to be right is another matter. For that the conditions are exacting and severe. First, there must be comprehensive knowledge; then, there must be sound method; and lastly, there must be the right temper or balance of mind-a combination that is by no means easy to obtain.

I must not pursue this subject as you will see at once that it is capable of being pursued. I only 
interpolate these few words to explain what I mean when I go on to say-still from the same restricted point of view-that, while I agree more often with my own countrymen, I learn more from the Germans.

Again I must pause for a moment, to guard myself against doing injustice. It would ill become me to complain of my own countrymen in this matter. When I came back to Oxford as Ireland Professor four and twenty years ago, the doctrine that I ventured to preach was: Don't let us be too ambitious; let us plan our work on a large scale, and be content to take the humbler departments first. Let us make sure of our ground as we go on. Let us begin by seeing that we have trustworthy texts; then let us take up the literary problems, and work them out as well as we can; let us practise our hands on commentaries and the like. In this way we shall gain experience, and make ourselves fit to aim at higher things.

There was in my mind something of Browning's :

Oh, if we draw a circle premature,

Heedless of far gain,

Greedy for quick returns of profit, sure

Bad is our bargain!

That is true of learning, and true also of religion; but it is not the whole truth of either. I suppose that really a programme such as I have described was more congenial to my own mind; I knew that I was not myself ready, and greatly doubted whether the nation at large was ready, for anything more heroic. It might be said, too, that a similar atti- 
tude was really characteristic of the great Cambridge scholars of the third quarter of the last century; so that the work of the last twenty years has been very much a continuation of theirs.

However this may be, if we take such a programme and measure by it the performance of the last twenty years, English theologians have not been idle. First, as to texts: the Latin versions-an immense fieldhave been pretty nearly mastered (at least so far as the publication of texts is concerned), and that mainly from Oxford. The Syriac versions are divided between Cambridge and Oxford, with a balance on the side of Cambridge; there too the most important work has been done. The Coptic brings us back to Oxford, where something has also been done upon the Armenian. Strange to say, the Continent has really little to place by the side of this, though equivalent work has been done in other spheres. Again, there is the mass of new material rendered available by Dr. Charles and Dr. James, the great Cambridge LXX, and admirable outlying work of the highest quality from both Universities. I am thinking of such things as Mr. C. H. Turner's Canons, and the Cambridge Texts and Studies.

Then, as to literary problems: more has really been done, at both Universities, than quite appears upon the surface; though Sir John Hawkins's Horae Synopticae is a leading authority on the Continent as well as here-I might say, the leading authority, because it is the one book that everybody trusts. There is also a quantity of carefully prepared material, 
like the Sy'nopses of Rushbrooke, and Dr. A. Wright, and Moulton and Geden's Concordance. And now we have to add two very valuable works, Fohannine Vocabulary and Fohannine Grammar, by Dr. Edwin A. Abbott.

Meanwhile at Cambridge, the home of commentaries, the succession of the great triumvirate has been worthily kept up by the Dean of Westminster and Dr. Swete; in Oxford perhaps our best strength has gone into the Old Testament, though we too have done something also at the New. The country as a whole has put a great deal of honest work into Hastings's Dictionaries and The Encyclopaedia Biblica. We have been gradually educating ourselves; and our self-education has taken especially this form.

One is accustomed to think modestly of our English theology, in the technical sense. But, after all, when the items for the last twenty years come to be added up, they make quite a considerable total. And much of what has been done is sound and solid work, not subject to the ebb and flow of opinion, but a permanent possession.

Nor ought we to forget, on rather different lines, the great work that has been done by the little company of friends who produced Lux Mundi, in the sphere where thought and practice meet. That work has been a public force of no small importance in the history of the period; but it stands rather apart from our present survey. Nearly all the other work that I have mentioned has been of a sober hue. It has been steady and sound, but it has not 


\section{Tzuenty Years of Research}

dealt much in experiment; and it has been especially chary of experiment on the highest matters. If Dr. Hatch had lived, we should probably have had more of enterprise to chronicle. Dr. Moberly's Atonement and Personality was a work of marked originality; and we have also had experiments from Dr. Edwin Abbott, and some others of less importance. But, as a rule, English work of the last twenty years has been neutral or defensive. I fully believe that this period, not only is coming, but has come to an end. There is evidence around us on many sides that a new and more adventurous and inventive spirit is abroad. I have been speaking only of the past; and it is with reference to the past that I think we feel the contrast when we turn to Germany.

We are not called upon to judge. There may be some things that we should deprecate, along with much that we should find to admire. But the strong point of Teutonic science is its persistent spirit of forward movement. With us, if a good piece of work is done, it lasts for a generation; whereas in Germany, no sooner does a definite result appear to be gained, than new questions begin to be asked, and new combinations attempted.

Another excellence is the close inter-connexion and cohesion of everything that is done. IVith some twenty-one fully staffed Universities in the German Empire alone (besides those in German Switzerland and Austria), each watching all the rest, and all throwing their knowledge into a common stock, whatever advance is made is made all along the line. 
When a German scholar sets himself a particular thesis, his first step is to get to know as nearly as he can all that has been written about it. In this way every step is based upon previous steps, and the continuity of research is never broken. With us, dashing but desultory raids are apt to take the place of what is in Germany the steady disciplined advance of a regularly mobilized army. It is true that this advance may include many a movement that is unsuccessful, many an experiment that fails; but there is never any lack of criticism to correct mistakes, and the ranks soon close again after defeat.

For these reasons, which I am afraid I have been rather long in explaining, the review of the situation which I am about to attempt will be mainly concerned with what has been done in Germany; and one consequence will be that I shall have to tax your patience with a string of rather unfamiliar names and titles. If you will kindly bear with this for a while, I hope that something constructive and of general interest may emerge by degrees.

The present moment is favourable for the retrospect that I am proposing. Three books have recently appeared which cover the ground that I desire to cover: Weinel, Fesus im neunzehnten Fahrhundert ('Jesus in the Nineteenth Century'), Tübingen u. Leipzig, I903; Steinmann, Die geistige Offenbarung Gottes in der geschichtlichen Person Fesu ("The Spiritual Revelation of God in the Historical Person of Jesus Christ'), Göttingen, I903 ; Schweitzer, Von Reimarus zu Wrede 
('From Reimarus to Wrede'- a title very nearly' equivalent to Weinel's; it is a survey of a century and a quarter of research and discussion), Tübingen, 1906.

Weinel is a member of a party that among the writers of the present day is numerous and clearly defined; and he is one of its most sanguine members. $\mathrm{He}$ is not much troubled by misgivings. He has his solution for most things in heaven and earth, and he regards it as his mission to preach these solutions far and wide. The book might be called a typical product of current theological liberalism. Its object is to carry on the liberal propaganda. For this it is in many ways well adapted; it is popular in style, and frankly and brightly written. Though it represents views that are largely destructive, it has also a positive side which is put forward with considerable fervour. But I imagine that it will leave behind in the minds of many readers a number of questions to which it gives no sufficient answer.

Steinmann is a writer of a different order. He has not the same popular gifts; his style is cumbersome, and I cannot help thinking that his book might with advantage have been much shorter. His saving virtue is thoughtful independence, a spirit calmly objective. He stands aloof from parties, and criticizes in turn now one side and now the other. But, although his ostensible purpose is reconstruction, he makes upon me the impression of giving up more than he need. This is done not so much in the way of argument as in the way of assumption. Though more con- 
servative in temper, Steinmann shares a good many of the premises of Weinel and his friends. $\mathrm{He}$ is himself a Moravian, and this fact has deeply influenced his thinking. He shows an almost nervous dread of anything in the least degree external in religion. The tendency is common in Germany, but it appears in Steinmann in an extreme form. It is strange that it should not be seen that, however inward a conviction may be and however internal the process by which it is reached, it must sooner or later express itself externally. Spirit must needs clothe itself with body; and it is only in this outward form that one spirit can communicate with another. The external may come in at different points in the process, but the internal without the external cannot exist. We in this country have learnt this lesson from Dr. Moberly and his friends; and I do not think that it will be soon forgotten.

I cannot adopt all Steinmann's presuppositions; I could not accept all his conclusions; but I welcome much of his criticism both on the right hand and on the left. This, and the attitude which it represents, is to me the best thing in the book.

From a general point of view, Weinel's book is up to a good average, and Steinmann's perhaps somewhat above it, but the third book that I mentioned seems to me in many ways more notable than either. A. Schweitzer's Von Reimarus zu Wrede is the most striking work of its kind that I have read for some time. The author is young-he is a Privatdozent at Strassburg-but, if he has something of the weak- 


\section{Twenty Years of Research}

ness, he has also in full degree the strength of youth. He knows that he is one-sided, but he glories in his one-sidedness. He takes the line that only by the pursuit of a relentless logic is it possible to arrive at the truth. His own logic is relentless, and he does at least succeed in presenting that side of the truth which he wishes to bring out in a very vivid and impressive manner. The book is written with a kind of enthusiasm; a single impetus carries it onwards from beginning to end. There is no respect of persons; the author has his strong likes and dislikes, which he is at no pains to suppress. As a rule he favours the innovators; drastic criticism generally enlists his sympathies. He has an imaginative grasp of his subject; he writes with clearness and vigour, and with a more than ordinary command of metaphor. He has a good sense of proportion, and groups his subjects happily. But perhaps the most noticeable thing about him is the sturdy individuality with which he has chosen his own line and holds to it through thick and thin.

There is naturally a great difference of scale between Schweitzer's book and that of these lectures. $\mathrm{He}$ appeals to the technical student, and can assume a large amount of previous knowledge which it would not be right for me to assume. I differ from him, as will be seen, somewhat profoundly. And yet it would be no more than just to describe a full half of these lectures as really based upon Schweitzer's labours. At least they would have taken a different and less satisfactory shape, if I had not had Schweitzer's 
work before me. If I should succeed in giving to my treatment of the subject definiteness and lucidity and logical coherence of outline, it will be very largely due to him. There is no recent book of the kind that I have found so helpful.

The conspicuous merit of this writer is that from first to last he holds a single clue firmly in his hand. This clue is the apocalyptic teaching that plays a rather prominent part in the Gospels, especially in the Synoptics. The most distinctive aspect of the research of the last twenty years has been the way in which the questions raised by this teaching have steadily come to the front.

But before I endeavour to explain how this has come about and what it means, it is necessary that I should first spend a few moments in explaining the terms that I shall have to use.

There is, in particular, one long and rather ugly word that I am afraid cannot be avoided. 'Eschatology' is the doctrine of the 'last things', or that group of ideas which is concerned with the catastrophe, or series of catastrophes, which ushers in and accompanies the end of the world. These ideas are embodied in writings which bear the general name of 'apocalypse', or 'revelation' of the signs and process of the end. We have, of course, one classical example of an apocalypse in the book which comes last in our Bible-the Apocalypse or Revelation of St. John. Really, however, as we now know, this book did not at all stand alone. There was indeed one book in the Old Testament as well as in the New which 


\section{Twenty Years of Research}

had very largely the character of an apocalypse-the book of Daniel.

This book can, as it happens, be dated with a considerable degree of exactness between the years $167^{-}$ I65 в. C. It was not absolutely the first apocalyptic writing, but it is the first that has come down to us as a separate book. Between the time of the Maccabean rising and the rising under Barcochba, the last convulsive effort of the Jewish state in I 32- $^{2-}$ I 35 A. D., there appeared a whole series of apocalypses one after the other-the Book of Enoch, the Psalms of Solomon, the Assumption of Moses, the Book of Jubilees, the Ascension of Isaiah, probably the original of the Testaments of the Twelve Patriarchs, the socalled Fourth Ezra, the Apocalypse of Baruch, the Book of the Secrets of Baruch.

In the middle of the last century only two of this long list of books were at all generally known-the Testaments of the Twelve Patriarchs in its later form, and the work now commonly called Fourth Ezra; printed as chapters iii-xiv of Second Esdras in our Old Testament Apocrypha.

The middle of the last century supplies a good landmark. It was in the year $185 \mathrm{I}$ that Dillmann published the Ethiopic text with translation of the Book of Enoch, and Hilgenfeld his important collection of texts entitled Fiidische Apokalyptik in 1857 . At the present time nearly all the books, through the indefatigable labours of Dr. R. H. Charles of Dublin and Oxford, and Dr. M. R. James and Dr. Rendel Harris of Cambridge, are readily accessible. It will 
be understood what a difference this has made to the whole field of study.

The period during which the Apocalypses have been practically available would thus cover a little more than half a century. But it always takes some time before new knowledge is brought to bear. It is for this reason that I have limited the retrospect of the present lecture to the last twenty years. Baldensperger's Das Selbstberusstsein Fesu im Lichte der messianischen Hoffnungen seiner Zeit ("The Selfconsciousness of Jesus in the light of the Messianic Hopes of His Time') is dated Strassburg, 1888 (ed. 3, 1903). This was the first book to collect on a large scale the apocalyptic data with a view to the light thrown by them upon the subject-matter of the Gospels, though it is fair to add that Dr. Edersheim ${ }^{1}$ had already utilized many of these data in his Life and Times of $\mathcal{F}$ esus the Messiah, published first in 1883 . Baldensperger had one or two precursors on a smaller scale, but roughly speaking he may be said to have inaugurated the apocalyptic or eschatological period of Gospel study. Since that time we might almost apply to the study of the Gospels that enigmatic phrase, 'the kingdom of heaven suffereth violence, and the violent take it by force.' If we do not press 'the violent' too hard, it may stand for the apocalyptists. The dominance of this school may be said to extend over about twenty years.

1 Dr. Edersheim was a Jewish scholar, born in Vienna, who embraced Christianity and ultimately became a clergyman in the Church of England. The book I have mentioned is still of value from its great wealth of illustrative matter. 


\section{Twenty Years of Research}

What then is the bearing of all this body of literature on the study of the Gospels? So long as only one or two of the apocalyptic books were known it was natural that no great attention should be paid to them. They were hardly recognized in their true character: the book of Daniel, for instance, was hardly treated as an apocalypse, and the Revelation of St. John was regarded as a work sui generis, the contents of which received the strangest interpretations. But when these two or three grew into a whole library spread over some three hundred years, a different estimate had to be put upon them.

It may be well at this point to raise a question which in the strict chronological order of events did not come up until later. Apart from Christianity, what position did the apocalyptic writings hold in relation to the Jewish thought of the time? Two distinct streams are observable in Jewish thought about the Christian era: on the one hand there were the apocalypses, which are now seen to have been far more important and more widely diffused than had been supposed; on the other hand there was the legal teaching, based upon the study and application of the Mosaic Law, which we associate with the Pharisees as they are described for us in the Gospels, the same type of teaching that at a later date was embodied in the Talmud. Within the last few years, since the beginning of the present century, quite a lively controversy has arisen between Christian and Jewish scholars on this question of the relative importance of what may be called the legalist RECON. 
or Rabbinical and the apocalyptic elements in Judaism.

On the Christian side the controversy was opened by a work on Judaism in the time of Christ by Prof. W. Bousset of Göttingen, Die Religion des Fudentums im neutestamentlichen Zeitalter ('The Religion of Judaism in the New Testament Period', Berlin, I903; a second edition, much re-arranged and re-written, appeared in October, 1906). The survey was largely based on the literature of which I have just been speaking as either newly discovered or but recently published in a form generally accessible. It is not surprising that this should have brought up some eminent Jewish scholars, who protested somewhat indignantly that the apocalypses had nothing to do with the really representative or official Judaism. These writings, they maintained, were all more or less abnormal, if not definitely heretical. The only authorized form of Judaism was that which found expression in the Talmud. Along with the different estimate of the representative character of the apocalypses there also went a different estimate of their moral value. To a Christian, and indeed it may be said to a modern, the apocalypses contain much that is at least quite as attractive as Rabbinism. The fact is that the Judaism of the time of Christ had a wider and more open horizon than that of a hundred years later. The result of the terrific and almost superhuman efforts that the Jews made to throw off the Roman yoke was a long reaction which has lasted almost to our own time. When the great effort failed, 
Judaism withdrew into its shell; it contracted its outlook and turned in upon itself. It gave up the hope of divine intervention that had at one time seemed so near, and was content to brood upon its past.

The Talmud is so vast, and the language in which it is written has been as a rule so unfamiliar to Christian scholars, that we have been accustomed to think of the Jews, and they have thought of themselves, as alone possessing the key to it. As a matter of fact, Prof. Bousset did not possess the key. Such knowledge as he had of the Talmud was acquired at second hand. His book was really meritorious and useful, and it rested upon a considerable basis of learning, but it did present this weak side to his critics; and, although he replied with a pamphlet a few months later (1903), he showed his consciousness of the fact, only insisting that they in turn did less than justice to the literature that they practically put on one side. The honours were really divided; either party showed itself one-sided in turn. The irritation of the Jewish scholars was greater than it need have been or ought to have been. We can now strike the balance more dispassionately; and a lesson has been learnt which we may hope will bear fruit in the future.

We must think of the Jewish Church and nation in the time of our Lord as presenting a more varied and broken surface than we have been in the habit of supposing. It is true that in Jerusalem and at the centre the scribes and Pharisees (i. e. the Rabbinical type of religion) really predominated, as the Gospels 
would lead us to believe they did, and that they were not wholly given over to formalism and hypocrisy. But we may imagine that in the hill country of Judea and Galilee, and in many a quiet corner besides, there were households like those of Zacharias and Elizabeth or Joseph and Mary where less conventional ideas were silently cherished; and not only so, but even in the official circles themselves all would not be on the same dead level. The mere existence of books like the Psalms of Solomon and the Book of Jubilees and the Assumption of Moses and the Testaments of the Twelve Patriarchs is proof that there was a great deal of genuine religion with its roots struck deep in the writings of Psalmists and Prophets. Perhaps at no time either before or since has there been so much aspiration, so much ardent longing for a future in which God should reign more visibly and triumphantly than ever in the past. In this attitude of intense expectation culminated the preparation in history for the coming of Christ; it was in the midst of it that $\mathrm{He}$ came, and to it that He appealed. Doubtless the expectation expressed itself in forms that seem to us strangely materialized; but these forms were not so much hard and fast, dry and scholastic, as fluctuating and kaleidoscopic; in part they were the outcome of conscious symbolism, and even where they were not this, we have to remember that the dividing-line between figure and fact, symbol and substance, was far less sharp and precise than it is with us. Though the age with which we are concerned was not exactly a poetic age-at least, 


\section{Twenty Years of Research}

not poetic in the literal sense within the geographical limits that we are contemplating-there was a vein of poetry in it, and the world did not then distinguish so closely as we do between poetry and prose.

I have said that for a full half century, from about I 850 to the present time, the apocalyptic materials have been accumulating, and becoming year by year more accessible and better defined. For about a generation this process had been going on quietly in the background without attracting any great notice, when with the appearance of Baldensperger's book it was brought deliberately and in full volume into the field of research on the Life of our Lord. Of course it had been there before, and it had entered more or less into the research of the earlier part of the century, but the way in which it had done so had been, comparatively speaking, casual and subordinate. Before Baldensperger one little discovery had been made, or thought to be made, which affected to some extent the statement of the problem. This was the indication by the French Protestant Timothée Colani of the so-called 'Little Apocalypse' in the great predictive discourse (Nark xiii, Matt. xxiv, Luke xxi) originally spoken on the Mount of Olives. This idea of Colani's was taken up in several quarters, and elaborately worked out by Weiffenbach (Der Wiederkunftsgedanken Fesu, 'Jesus' conception of His Return': Leipzig, I873). It was pointed out that within the larger discourse there was enclosed a smaller, separable from the larger, which expressed the Jewish ideas of the time in stronger colours. The conclusion lay 
near at hand that this was an interpolation or insertion in the original discourse, written in any case before the fall of Jerusalem in $70 \mathrm{~A}$. $\mathrm{D}$. and Jewish, or more probably Jewish-Christian, in its character. The common feature in the two discourses was the thought of the Coming or Return of the Messiah. It was a peculiarity of Weiffenbach's that he explained this Coming or Return as intended in the first instance for the Resurrection; according to him our Lord really predicted His Resurrection, and not any supernatural manifestation at the end of the world. In this suggestion, however, I believe that he has had no followers. On the other hand, many have availed themselves of the hypothesis of interpolation to reduce or minimize the eschatological elements in our Lord's teaching.

The question as to the literary structure of the chapters involved was in any case only a detail. As I have said, Baldensperger was the first to collect all the apocalyptic material he could, and bring it systematically to bear upon the Life of our Lord. At the same time the title of his book (Das Selbstberunsstsein $\mathcal{F}$ esu im Lichte der messianischen Hoffnungen seiner Zeil) shows that he had a double object in view. The apocalyptic parallels were considered with reference to their bearing upon a psychological analysis of the self-consciousness of our Lord. This was a bold attempt, and it necessarily contained a good deal that was speculative. And the connecting thread of speculation was derived, not so much from a study of the conditions existing in the 
first century A.D., as from the kind of reconstruction current in the circles of modern liberal theology.

According to Baldensperger, the primary constituent in the consciousness of Jesus was the sense of a unique relation to God. On to this consciousness there were grafted the Jewish conceptions of the Messiah and the kingdom of God; and these ideas were more and more spiritualized, until everything earthly and political was stripped from them. For a long time, from motives connected with our Lord's method of teaching, no direct claim was put forward; in particular, all that might serve to excite political passion was carefully avoided. The disciples were left to draw their own inferences. At last, at Caesarea Philippi, Peter made his bold avowal. But from that time the inevitable end was coming into view. Jesus Himself began definitely to prepare $\mathrm{His}$ disciples for it; but, in doing so, He took up another side of the Jewish expectation; beyond the descent into the valley of death, He saw His own return 'in power and great glory'.

In the working out of this theory, which in its main outline is familiar to all of us, as it is substantially that which has for some time with slight differences in detail been generally accepted, Baldensperger struck a compromise between the picture that came out from a study of the Jewish contemporary writings and that which appeared to result from modern criticism of the narratives of the Gospels. The two different, and in some ways conflicting, aspects of this picture he tried to harmonize as best he could. 
The next step was to be of another kind. The time had come to have done with compromises. In I 892 there appeared a short pamphlet of sixty-seven pages by Johannes Weiss, son of the veteran Professor Bernhard Weiss, of Berlin, and himself now Professor at Marburg, which altered the whole situation, and compelled an answer to more peremptory questions.

The decisive term was the 'kingdom of God' or 'kingdom of heaven' ; and this it was that Johannes Weiss set himself primarily to explain. The question was 'in the air'. It had been propounded as the subject of a prize competition at Leyden, and two meritorious essays sent in for this by Issel and Schmoller had been published in 1891. The latter of the two laid especial stress on the eschatological sense. Johannes Weiss did more than lay stress upon it; he asserted that it was the sense, the only sense -in other words, that the kingdom of God was not, as was generally supposed, partly present and partly future, but wholly future, and wholly transcendental or supernatural. It was present, not strictly and literally, but in the sense of being close at hand. The casting out of demons in particular implied that Satan's power was broken, and that the moment for the full manifestation of God's kingdom was very near.

This, however, the exact moment of its appearance, was the one thing that even our Lord Himself professed not to know. It was not so near as it seemed. At first He had come forward with the same message as the Baptist, 'Repent, for the kingdom of heaven is at hand' (Matt. iv. I7, Mark i. I4). When the 


\section{Twenty Years of Research}

Twelve were sent out on their mission, still the same message was repeated (Mark vi. I 2). The end of the age was near, but it could only be ushered in by a general repentance; and this general repentance was delayed.

As time went on it became evident that the repentance of the people would never be complete. The mass was really too hardened and obstinate. The invitation was given, but not accepted.

What was to be done? By degrees it dawned upon the consciousness of Jesus that to bring about the great event a great act of self-devotion was needed; and the call came to none other than Himself. All along $\mathrm{He}$ had known that $\mathrm{He}$ was to be the agent in establishing the kingdom. In other words, He had the Messianic consciousness; and yet He went about performing none of the functions of the Messiah-at least, none of the clear and unmistakable functions such as would have been understood at once. He did not even give Himself out as the Messiah, though $\mathrm{He}$ accepted the title (or its equivalents) when it was given to Him by others (e. g. by the demoniacs). It was on account of this strange reticence and reserve that the Baptist came to put his question, 'Art thou He that should come, or do we look for another ?' (Matt. xi. 3). The reply that he received is enough, but not a word more than enough ; nothing is added to satisfy what we might consider a reasonable curiosity. But at the same time the significant hint is given, 'Blessed is he that shall not be offended in Me' (Ma.t. xi. 6). 
The characteristic activities of the Messiah, like the characteristic glories of His kingdom, were still held back. Something was to intervene before they could be revealed; and that something was $\mathrm{His}$ death. $\mathrm{He}$ was to give up His life as 'a ransom for many' (Mark x. 45, Matt. xx. 28). In like manner, at the Last Supper Jesus speaks of His blood as 'shed for many' (Mark xiv. 24 and Matt. xxvi. 28) : 'for many' means not for the disciples only, but for the whole people. ${ }^{1}$

When the crisis was over, when the bitter cup had been drunk to the dregs, then at last the obstacle would be removed, and the Son of Man would come in power and great glory, and the Messianic reign would begin. First would come the judgement, and after that the reign.

This is an outline of the development of things as Johannes Weiss conceived it. It will be seen that, according to him, everything is thrown into the future. The moral teaching that we get in the Gospels is not so much the ethics of the kingdom as ethical teaching that fits for the kingdom. Schweitzer calls it an Intcrimsethik (pp. 357, 362), i. e. designed for an interval which is expected to be short; it is a sort of expansion of the idea of 'repentance', the condition of the soul under the eye of the righteous Judge. There is no real difference in attitude between the Baptist and Jesus Himself.

${ }^{1}$ Schweitzer, p. 237 ; J. Weiss, Predigt, \&c., ed. 2, p. 201 ; in his second edition Weiss expresses some doubt as to the genuineness of the saying (p. 197). 
The outlook of both is fixed upon the future. The real and important difference is that, whereas the Baptist knew himself to be only the Forerunner, Jesus knew that He was more than the Forerunner; He knew that the kingdom was $\mathrm{His}$ by right.

Jesus spoke of Himself as the Son of Man. There will be much more to be said about this title later. I only allude to it now in order to say that for Johannes Weiss its significance is essentially transcendental and eschatological. It means the Nessiah in His character as Judge, as in the Similitudes of the Book of Enoch. From the way in which our Lord used it, speaking as it were objectively and in the third person, it would often not seem that $\mathrm{He}$ was speaking of Himself. At the very last, at the hearing before the Sanhedrin, it is only the express assent of Jesus that identifies Him with the Son of Man, and that makes His assertion that the Son of Man would come with the clouds of heaven into an assertion that $\mathrm{He}$ Himself would so come.

This sketch of the theory of Weiss is based mainly on Schweitzer's summary, checked by the second edition of Weiss's book which appeared in 1900 . I unfortunately missed the first edition when it came out; there is no copy in the Bodleian, and I have not been able to find one in Oxford. ${ }^{1}$ The second

1 Through the kindness of Professor Burkitt I have been enabled to consult the copy in the Cambridge Library; and the generosity and perseverance combined of Dr. George Milligan-clari patris clarus filius-have since enriched me with a copy of my own. 
edition is 'entirely recast'; it has grown from 67 pages to 2I4; and Schweitzer evidently prefers the first edition. I can quite imagine that it was the more telling, as it was also the more uncompromising, of the two. But what Johannes Weiss writes is always fresh and forcible and suggestive.

Two of Schweitzer's terse and pregnant sentences put the characteristic features of the Weissian theory in a nutshell :

(Jesus) does not found the Kingdom; $\mathrm{He}$ only announces it. He exercises no Messianic activity, but $\mathrm{He}$ waits, with the rest of the world, for God to bring in the Kingdom supernaturally (p. 236 ).

Or-to put it in a slightly less paradoxical formthe ministry of Christ on earth was but preliminary; the real Advent, the real Kingdom was to come.

When Schweitzer comes to Johannes Weiss, his enthusiasm knows no bounds. At last he has found a system that, like Strafford's famous policy, really deserves the name of 'Thorough'. He regards it as marking an epoch in the history of the subject, as no doubt it does. It was not really to be expected that a theory in many ways so novel should meet with general acceptance. Schweitzer consoles himself with the reflection that it usually takes about a generation for any new theory to become established.

It was a noticeable fact that the two leading older authorities on the history of Judaism, Wellhausen ${ }^{1}$

1 Julius Wellhausen is the writer who has done more than any one man to revolutionize our conception of the Old Testament. It should be noted that Schweitzer had not before him Wellhausen's 


\section{Twenty Years of Research}

and Schürer ${ }^{1}$, both dissented, or (more strictly) implied dissent, because they were not writing directly against Johannes Weiss.

Wellhausen's views were expressed in the successive editions of his Israelitische und jüdische Geschichte ('History of Israel and of the Jews'), which first appeared in 1894. Schürer declared himself in an academical address, Das messianische Selbstberunsstsin Fesu Christi ("The Messianic Self-consciousness of Jesus Christ '), published in 1903. The opposition really turned upon the question of the relation of the teaching of our Lord to the contemporary Judaism. The novelty of such a theory as that of Johannes Weiss consisted largely in the extent to which it made our Lord accept the doctrines of current Judaism. Up to the year 1892 it had been usual, especially in the liberal camp, to think of our Lord as in strong antithesis to these. Both Wellhausen and Schuirer distinctly occupied that standpoint. Both insisted on the discarding by Christ of all that was political in the Jewish ideal, the bitter antagonism to Roman rule. It was characteristic of Johannes Weiss to deny, or at least to minimize, the existence of this political element. For him the main point was the transcendental, supernatural aspect of the conception. The

views on the eschatological question in their latest form. They are very carefully stated in his Einleitung in die drei ersten Evang. (1905), especially pp. 98-108.

${ }_{1}$ Emil Schürer is the author of a History of the Jewish People in the time of Christ, which is a vast repertory of knowledge on the subject. 
coming of the Messiah and the realizing of the kingdom was all a direct intervention of God upon earth.

With Wellhausen and Schiirer may be classed other writers of middle age like Professor von Soden, of Berlin, and younger men like Professor Paul Wernle, of Basel. We may also include in the group Harnack in his famous lectures. With all these the significance of the teaching and life of Christ lay far less in His adoption of Jewish ideas than in $\mathrm{His}$ rejection or correction of them.

But then it had to be remembered that the current ideals of Judaism were very far from homogeneous. There were, to begin with, as we have seen, the legalist ideal and the eschatological ideal more or less in contrast with each other. Every one, I think, is agreed that our Lord did not adopt or approve of the legalist or Pharisaic ideal. The utmost that can be said is that there were some open-minded and religious Pharisees whom $\mathrm{He}$ did not condemn along with the rest.

But even the other, eschatological, ideal was by no means all of a piece; it was made up as it were of a number of different strands, of which it was quite possible to take one and leave another, or partially take one here and there. Clearly discrimination was necessary, and, it might be, fine discrimination.

Probably from this point of view the subtlest and most skilful of the alternatives offered for the theory of Johannes Weiss was that put forward by Professor 


\section{Twenty Years of Research}

Bousset, of Göttingen 1. There were several points that he made in opposition to Weiss. He took the line generally of reasserting the originality of Christ, which seemed in some danger of being depreciated. We have seen that Weiss made little of the difference, at least in attitude, between the Forerunner and the Messiah. But as against this, Bousset pointed to the difference in the popular estimate of them: the one 'came neither eating nor drinking, and they say, He hath a devil': the other 'came eating and drinking, and they say, Behold, a gluttonous man, and a winebibber, a friend of publicans and sinners' (Matt. xi. 18, 19). John was an ascetic, and Jesus was not an ascetic. This went along with other traits in the portrait of the latter. He had an intense feeling for the beauties of nature, the flowers of the field that neither toil nor spin; and not less for the lower world of animate being, for the birds of the air, or for the straying sheep. He entered equally into human joys and human sorrows, and showed an especial care for the 'little ones' who believed in Him.

All this, Bousset argued, was inconsistent with an uncompromising eschatology. It was an affirming of the joys of life, where eschatology implied their renunciation.

But then there was the double strain in the Jewish eschatology as it was held. One came from the

1 Some of Bousset's writings that bear upon the subject have been mentioned above (pp. $5 \circ$ f.). We may add Jesus in the Religionsgeschichtliche Volksbücher (Halle, 1904 ; E. T. 1906). 
ancient prophets and psalmists of Israel; the other came from foreign sources, as through the contact with Persian religion during the Captivity. It was the former only that Jesus really adopted; so far as He took over the transcendent supernatural side of the expectation, $\mathrm{He}$ transformed and spiritualized while He adopted it.

According to Bousset, the idea of the kingdom of heaven could not be thrown entirely into the future. The righteousness of the kingdom was a righteousness that could certainly be practised upon the earth, even as it was. At the same time, it was true that the present character of the kingdom was not put prominently forward. It was a 'mystery', hinted at in parables and dark sayings, but not intended to be thoroughly understood.

It will be seen that Bousset's was an attempt to mediate between the old and the new, between the apocalyptic school and its opponents. It, of course, was not, and is not, the last word in the controversy. But there were to be other important episodes in it before this sketch can be brought down to the present time. I must leave the subject at this point until next week. 


\section{III}

TWENTY YEARS OF RESEARCH (continued)

IN the year I 896, a young scholar, Hans Lietzmann, at that time Privatdozent at Bonn and now Professor at Jena, rather startled the world by publishing a tract entitled Der Menschensohn; ein Beitrag zur nutest. Theologie ("The Son of Man : a contribution to N. T. Theology ': Freiburg i. B. and Leipzig, I 896), in which he questioned on philological grounds the use commonly ascribed to our Lord of the title 'Son of Man' as a designation of Himself. He was not really by any means the first to do this, but he was the first to do it systematically and with a collection of practically all the relevant materials.

The question was raised at a time of marked advance in the knowledge of the language of Palestine in the time of our Lord. In the same year with Lietzmann's tract appeared another by Arnold Meyer called Fesu Muttersprache ("The Mother-Tongue of Jesus': Leipzig), surveying the ground and defining more exactly the distribution of the different dialects. At the same time eminent specialists like Wellhausen, Nöldeke, Kautzsch, and Dalman were laying the basis of a scientific study of their grammar and idiom.

RECON. 
The ground of Lietzmann's objection was that in Aramaic, the dialect spoken in Galilee and generally in Palestine at this time, such a phrase as 'Son of Man' as a title did not exist, and could not well exist, because the phrase was in use in a different sense, meaning simply 'man'. Lietzmann thought that the name was not used by Christ Himself, but that it was attributed to $\mathrm{Him}$ by the early Church through a misunderstanding. Greek-speaking Christians did not realize that ó viòs $\tau o \hat{v} \dot{a} \nu \theta \rho \dot{\rho} \pi o v$ was simply the equivalent of $\dot{\alpha} \alpha \nu \theta \rho \omega \pi$ s; and accordingly they were led to suppose that in passages like St. Mark ii. 28 ('The Son of man is lord of the sabbath '= 'Man is lord of the sabbath ') our Lord was speaking, not of humanity in general, but of Himself.

Both Wellhausen and Arnold Meyer had expressed views in different ways approximating to this; and at a later date (in I889) Wellhausen came round to the opinion that the phrase had not been used by Christ in a personal sense at all. ${ }^{1}$

It was difficult to maintain this sweeping conclusion in face of the strong attestation supplied by all parts of the Gospels, including the Fourth which had no reason of its own for adopting the phrase. And the high authority of Dalman (Die Worte Fesu, 1898) interposed on the other side. To this we may add that of Dr. Driver in his admirable review of the

1 Later still he seems to have gone back somewhat from this extreme position. But, in reading his Einleitung (1905), I find it not easy to be clear when he is expressing his own deliberate view, and when he is simply writing from the standpoint of the documents. 


\section{II. Tzenty Years of Research}

discussion in Hastings's Dictionary, iv. $582 \mathrm{f}$. It is an important point that the early Syriac versions have a special form of phrase which is not liable to confusion. But even if the phrase is to be taken as equivalent to 'The Man', there is no sufficient reason why it should not have been used. More will be said on this point later. On the whole I think it may be said that the radical objections of Lietzmann are at the present time no longer urged.

There remains, however, the still more important question, assuming that our Lord did use the title of Himself, exactly in what sense $\mathrm{He}$ used it. On this point Dalman's view is interesting. In order to explain it, we must go back a little to the data on which any view must be based.

It is agreed that in any case the use of the phrase is connected with the vision of 'one like unto a son of man' (i. e. 'like a man') in Dan. vii. I 3, but there is difference of opinion as to the nature of the connexion. There is also difference of opinion as to the extent to which the phrase was current as a designation of the Messiah in the time of our Lord. It occurs, in an eschatological sense, of the Messiah as Judge in the middle portion of the Book of Enoch, commonly known as the Similitudes. This is usually, but not quite universally, referred to the first century B.c. There are also some confirmatory allusions in 4 Ezra. But these do not in strictness amount to proof that the term was well known or much used. According to the degree in which it is supposed to have been, current opinions diverge as to the motive for its use. 
Some think that our Lord used it to veil His Messiahship; others, to proclaim it.

Then again we note that in the places in which the phrase is used in the Synoptic Gospels, it is used with two different sets of associations. In one group of passages it is associated with the humility of our Lord's mission upon earth as man ("The foxes have holes, and the birds of the air have nests; but the Son of man hath not where to lay his head'). In another larger group it is used of $\mathrm{H}$ is coming at the end of the world in power and great glory. It will be scen that much would depend on which of these groups was taken as primary, and which as secondary.

Dalman took the line that the title was not one generally current for the Messiah; that it was suggested to our Lord by Dan. vii. I3; that $\mathrm{He}$ used it more especially with reference to the human side of His mission, and in particular in connexion with the predictions of $\mathrm{His}$ own sufferings and death.

On all these points Dalman may be said to be the direct opposite of the eschatological school of which I spoke at length in the last lecture. It is characteristic of this school to maintain that the title was at least so well known as to be at once recognized as a name of the Messiah, and recognized as having reference to $\mathrm{Him}$ as the superhuman person who would appear in the last days to bring the existing order of things to an end and to establish a new order in its place.

In the last lecture I took Schweitzer as the latest and most thorough-going representative of this school. 
$\mathrm{He}$, as we might expect, directly challenges Dalman in regard to the points that I have just enumerated. He argues-and, I think it must be confessed, with force-that when our Lord spoke of the Son of Man as undergoing suffering and death, the disciples were bewildered and could not understand what He could mean; but when He spoke of the Son of Man as coming in the clouds of heaven, they at once understood, and began to dispute who should sit at $\mathrm{His}$ right hand and at $\mathrm{His}$ left.

The only point on which the two theories, though from quite different directions, seemed to some extent to approach each other, was that in neither was it assumed that our Lord went about proclaiming His Messiahship, but that in the one He took the title Son of Man expressly in order to veil it, while in the other He either spoke of the Son of Man in the third person in such a way as not clearly to identify Him with Himself, or else His discourse on the subject was confined to His own disciples, and that in the last period of His ministry. Not until His trial before the high priest did our Lord definitely assume the title, with all that it involved, in a manner at once public and unequivocal.

With the beginning of the present century the controversy as to the title 'Son of Man' secmed to be gradually subsiding, but only to give place to another of still more far-reaching importance. This new period was opened by Wrede, Professor at Breslau, in his Messiasgeheimnis in den Fangelion ('The Messianic 
Secret in the Gospels') published at Göttingen in $190 \mathrm{I}$.

The chief merit of Wrede's book consists in its independence, its originality, and the newness of the questions which it raises. I consider it to be not only very wrong but also distinctly wrong-headed. But although such a judgement may affect the book as an isolated literary production, it affects it far less as a contribution to theological inquiry. In the end almost every statement of a new problem, or problems, does good. The statement may be more or less a failure in itself, but it leads to a fresher and stronger apprehension of the facts.

I could not describe the book as attractive to read. Wrede has directness and ability, and he never minces matters; as I have said, he belongs to no school, and repeats the formulae of no school. But he writes in the style of a Prussian official. He has all the arrogance of a certain kind of common sense. His mind is mathematical, with something of the stiffness of mathematics-a mind of the type which is supposed to ask of everything. What does it prove? It is a mind that applies the standards to which it is accustomed with very little play of historical imagination. If it cannot at once see the connexion of cause and effect, it assumes that there is no connexion. It makes no allowance for deficiencies of knowledge, for scantiness of sources and scantiness of detail contained in the sources, for the very imperfect reconstruction of the background that alone is possible to us. If there is upon the surface some appearance of incoherence or 


\section{II. Twenty Years of Research}

inconsequence, it is at once inferred that there is real incoherence and real inconsequence. And the narrative is straightway rejected as history; though a little reflection would show that life is full of these seeming inconsistencies, and would be fuller still if our knowledge of the events going on around us did not supply us with the links of connexion which make them intelligible. Wrede argues as though we could exhaust the motives of the actors in events that happened nearly nineteen hundred years ago, whereas nothing is more certain than that we cannot in the least come near exhausting them.

I have said that the merit of the book lies in its calling attention to a new group of facts, to a group which, although it had of course been observed before, had not been appreciated in all its bearings. This group of facts has to do with what is called 'the secret of Messiahship', the way in which the Gospels-and, more particularly, the fundamental narrative-Gospel, St. Mark-furnish indications that, although our Lord came forward as the Jews' Messiah, He nevertheless seemed anxious rather to suppress than to assert $\mathrm{His}$ claims to the title. Wrede collected together these indications, with a number of other statements that seemed to him to be more or less connected with them, and subjected them to a severe and drastic criticism. He chose, in the first instance, the Gospel of St. Mark as that which most modiern scholars take as the foundation for their reconstruction of the Life of Christ.

He began with the instances in which certain 
demoniacs confessed Jesus as the Messiah, but were bidden to hold their peace. These demoniacs, he contended, could have had nothing to suggest to them that Jesus was the Messiah; there was no psychological avenue by which they could arrive at such a conclusion. Therefore the narratives must be rejected as unhistorical.

He next took up the places in which, after performing miracles, Jesus enjoined upon the persons healed to keep silence as to what had been done to them. Any such injunctions of silence, Wrede argued, must be futile, because according to the Evangelist a number of other miracles was wrought without any prohibition. Therefore these too must be unhistorical injunctions.

Another characteristic of the second Gospel is the way in which it represents our Lord as repeatedly seeking to withdraw from the crowd, as courting retirement and solitude. Perhaps these statements could not be dismissed straight away; but they appear to be connected with the others, and at least lie under the suspicion of being unhistorical.

Of the same order is the explanation given in St. Mark iv. IO-I 2 of the teaching in parables, as though their object was to reveal to the disciples what was concealed from the multitudes. Here Wrede follows Jülicher's well-known work on the Parables. Jülicher (in Wrede's opinion) had quite sufficiently exposed the absurdity of this explanation. The parables, as we have them, were clearly not intended to conceal anything.

The Gospels give us the impression that Jesus 
went up to His last Passover at Jerusalem deliberately in order to die, and that He prepared His disciples for this by predicting His own death; and yet, when the catastrophe comes, it takes them by surprise. Clearly the object attributed to the journey and the prediction are alike unhistorical.

The dullness of apprehension ascribed to the disciples in this respect is only one case of an abnormal want of intelligence imputed to them. This too is to be classed with the other phenomena that we have been considering.

Really (Wrede maintains) a conscious purpose runs through St. Mark's Gospel, a purpose which may be understood when it is regarded in connexion with the early stages in the history of Christianity. The key to the whole is given by a verse which follows the account of the Transfiguration :-

And as they were coming down from the mountain, He charged them that they should tell no man what things they had seen, save when the Son of Man should have risen again from the dead (Mark ix. 9).

It was really the Resurrection which gave rise to the belief that Jesus was the Messiah. This appears distinctly both from the early discourses in the Acts and from the Epistles of St. Paul (Acts ii. 36, Rom. i. 4, Phil. ii. $6 \mathrm{ff}$ ). This was the earliest conception ; only by degrees did it come to be supposed that Jesus had claimed to be the Messiah during His earthly ministry. He had not made any such claim ; and there was a complete dearth of facts showing 
that He had made any such claim. How could that dearth of facts be plausibly accounted for? Just in the way in which St. Mark has sought to account for it, viz. by introducing all these prohibitions and hints of esoteric teaching and imputations of dullness and the like. The disciples had really known who and what their Master was, at least from the time of St. Peter's confession; but they had not been allowed to say.

Such was the way in which, according to Wrede, the early Church glossed over the flaw in its own title-deeds. St. Mark did not invent the theory; it was the early Church that invented it. But St. Mark gave it definite shape and substance.

What are we to think of this construction? I cannot easily conceive anything more utterly artificial and impossible. Imagine an ancient confronted with an awkward dearth of facts. What would he do? Accept the blank as it was-and then try to cover it up by all sorts of roundabout expedients and excuses, or boldly go in and fill up the blank with the facts required? All analogy compels us to believe that the second method would be followed and not the first. A twentieth-century forger or criminal of the type dealt with by Sherlock Holmes might conceivably cover up his tracks in the way that Wrede supposes; but that any first-century community or writer should so act is incredible. If the ancients deviated from strict veracity, they at least followed the maxim pecca fortiter. Where direct methods were open to them, we may be sure that they would prefer 


\section{Twenty Years of Research}

them; at least they would certainly not prefer methods so indirect and circuitous as Wrede imagines.

I really think that these considerations are enough, without following up this strange hypothesis in detail. One would like to cross-examine its author a little on the use which he makes of the Resurrection. It is true enough that the belief in the Resurrection bore a great weight of superstructure in apostolic times. But I doubt if at any time, from the first century to the twentieth, it has ever had so much weight thrown upon it as in this theory of Wrede's. It is not only the foundation stone, but apparently the sole foundation of the whole edifice of Christianity. Does Wrecle really believe this? Supposing that the Resurrection accounts for the rest of Christianity, what is left to account for the Resurrection? For the ordinary Christian it is prepared for and led up to in a hundred ways; but I think Wrede may fairly be asked what he has left to lead up to it. The elephant stands on the tortoise; but what does the tortoise stand upon? There is a passage in Bousset's Fesus which seems to me completely to overthrow Wrede's contention :-

We have certain knowledge that the belief existed from the very beginning among the Christian community that Jesus was Messiah, and, arguing backwards, we can assert that the rise of such a belief would be absolutely inexplicable if Jesus had not declared to His disciples in $\mathrm{H}$ is lifetime that $\mathrm{He}$ was the Messiah. It is quite conceivable that the first disciples of Jesus, who by His death and burial had seen all their hopes shattered and their belief in His Messiahship destroyed, might have returned to that 
belief under the influence of their resurrection experiences, if they had formerly possessed it on the ground of the utterances and general conduct of Jesus. But it would be wholly incomprehensible that the belief should have originated in their hearts after the catastrophe, for in that case we must assume that those marvellous experiences of the Easter days produced something completely new in the disciples' souls by a process of sheer magic, and without any psychological preparation. And that we are unable to assume precisely on the ground of our strictly historical point of view (pp. 168 f.).

It is Wrede's argument about the demoniacs turned against himself.

So far as I know, Wrede's reconstruction of the Gospel history is accepted by no one. At the same time his book made a certain impression, and has had a certain effect, chiefly through the criticism which it directs against other reconstructions, especially against that which is current in the camp of modern theological Liberalism. ${ }^{1}$ I shall have more to say about this in the next lecture. For the present I content myself with pointing out that, in this first destructive

1 Apart from particular criticism, it seems to me, looking from a distance, that Wrede's book has had a tendency to revive and strengthen that unfortunate spirit of perpetual carping from which Germany was beginning to free itself (cf. Harnack's famous Preface of I 896). It is pathetic to see how the better minds at the present time struggle against the grip of this spirit, though on the whole succumbing to it. Harnack has broken loose more than any one in his fine and true book Lukas der Arzt (1906); but even he feels the prevalent Geist des Verneinens dragging at his skirts, and has yielded to it more than he ought. Next to Harnack, in real independence and insight, I should place Johannes Weiss. 
part of his work, Wrede has for some way a companion in Schweitzer.

Schweitzer himself contrasts his own theory with that of Wrede as a thorough-going eschatology as against a thorough-going scepticism. I am afraid that I shall be again compelled to make a good deal of use of this ugly and cumbrous word, for which I had to apologize in my last lecture. This time we will try to be a little more accurate. In the last lecture I spoke of eschatology as dealing with the events which were expected to happen at the end of the world. Instead of 'the end of the world', let us say 'the end of the aeon or world-age', i. e. the end of the present period in the history of the world, or rather the period that was present in the time of the Apostles. Many of the Jews in the time of our Lord (I do not say all, and perhaps not a majority, but at least a large minority) fully expected that the worldage in which they lived was soon about to come to an end; and that it would end with a complete breakup of the existing order of things, through a direct divine interposition. The interposition was to be essentially supernatural. It was to take the form of a visible establishment of God's kingdom upon earth. The agent through whom the kingdom was to be established was the Messiah. There was to be a great crash and collapse of all human kingdoms, and the divine kingdom alone was to be left standing.

Schweitzer applies this belief in the study of the Gospels; and he applies it more thoroughly than had ever been done before, even by the school to which he 
himself belongs. The leaders of the school (such as Baldensperger and Johannes Weiss, especially the latter) had explained a large part of our Lord's teaching as essentially eschatological, but they had not gone beyond this. They had explained large parts of the teaching as eschatological but not the Life. In a tract which he brought out at the same time as Wrede's book, Schweitzer applied the same explanation to the Life; and that explanation he repeats on a larger scale in his volume Von Reimarus zu Wrede.

There are three great secrets-real secrets-in the Life of our Lord. There is the secret or mystery of the Messiah; the secret or mystery of the Kingdom ; the secret or mystery of Suffering. All three are strictly eschatological; they belong to that cycle of current doctrine that has to do with the end of the age.

I. The secret of the Messiah is itself a part of this larger scheme. Jesus knows that $\mathrm{He}$ is the Messiah. He thinks of Himself especially under the form of that particular Messianic title 'the Son of Man'. How He came to think of Himself thus lies beyond us. It is vain to speculate about it; we must be content to accept it as a fact.

But although Jesus knows that $\mathrm{He}$ is the Messiah, $\mathrm{He}$ does not go about proclaiming Himself in this character. He has indeed the full consciousness of Messianic authority; but $\mathrm{He}$ does not assert, but rather conceals it. This is His 'secret', which $\mathrm{He}$ is anxious not to disclose too soon. He lets St. Peter make his confession; that is the first step in the 


\section{Twenty Years of Research}

disclosure; $\mathrm{He}$ is aware that St. Peter only knows it because it is God's will that he should do so.

But still, and up to the last, the knowledge does not travel beyond the Twelve. The outside multitude is perplexed about Him. It does not know what to think. It has a suspicion that really $\mathrm{He}$ is involved in the great divine event which it believes to be coming. But, so far as it ventures to put its suspicion into words, it would be inclined to say that the Prophet of Nazareth was Elijah rather than the Messiah. The Messiah was a supernatural personage who would appear upon the clouds of heaven. It would not occur to the ordinary Jew that one who walked the earth as a man could be the Messiah. But he might quite well be Elijah, the forerunner of the Messiah. Schweitzer holds that the phrase 'he that should come' was interpreted in this sense of Elijah, the human precursor of the superhuman Christ.

This is one of the elements of obscured and paradoxical truth that are really seized in a recent essay which identifies Jesus Himself with the Forerunner ${ }^{1}$. He was not the Forerunner in His own consciousness ; $\mathrm{He}$ is not the Forerunner of history-the world's history, as it looks back over the ages. But He was the Forerunner in the speculation perhaps of many contemporary Jews. He was unmistakably a man; and the revived Elijah was to be a man, not more than man.

Jesus (in Schweitzer's view) had begun to reveal what

'A paper entitled 'Christ the Forerunner' in Mr. H. W. Garrod's The Religion of All Good Men (London, 1906). 
He really was. He did so in the moment when He pronounced John the Baptist to be Elijah. But that was just one of those covert allusions, the significance of which could not be taken in all at once. The message of the Baptist in prison, and the reply of Jesus, and the discourse which followed on the true position of the Baptist, were indeed a landmark in the process of revelation; but they are a landmark rather from the point of view of Jesus Himself than for the rough apprehension of the crowd.

Even the solemn entry into Jerusalem at the beginning of the last week, although it was doubtless Messianic for Jesus, and possibly for the most discerning of His disciples, looking at events in the light of St. Peter's confession, had no such meaning for the crowd. We may see this from the sequel of the narrative. The other public actions of Jesus on the days before the preparation for the Passover were not such as would be recognized as Messianic.

According to Schweitzer, the secret of the Messiahship was really the secret betrayed by Judas. It was through Judas that the high priest was put in possession of it, and so enabled to propound that direct question, our Lord's assent to which carried with it the verdict of condemnation. Apart from this audacious and blasphemous claim, nothing deserving of death could be brought home to Him.

2. I have said that the secret of the Messiah was intimately connected with that other secret, the secret of the Kingdom. We must always remember that, from the eschatological point of view, the coming of 
the Kingdom was an essentially supernatural event. It meant the break-up of the existing order, the end of the world-age. It had to be ushered in by a series of catastrophes. And, therefore, during our Lord's life, it could not be, in the strict sense, present; it might be impending in the near future; but only as so impending could it be spoken of as present.

Schweitzer goes so far as apparently to deny that our Lord greatly altered the Jewish conception of the Kingdom. He seems to deny the political character of this conception. He denies that the frequent risings of which we hear were Messianic. In this I confess that I think he goes much too far. It may be a bare truth that we have no direct evidence that the outbreaks were ostensibly Messianic. It may be also true that there were a good many Jews for whom the Messianic hope was more or less clormant. But I imagine that from the time of the Maccabees to the time of Barcochba there was a Messianic background-or something like it-to every popular movement that swept over Palestine. I cannot think that the Zealots, for instance, were either simple brigands or a purely political party without any admixture of religion. Just as the book of Daniel reveals the spiritual atmosphere of the age to which it belongs, so also do the Psalms of Solomon reveal the like conditions a hundred years later, and the Assumption of Moses later still. I am, as I implied in the last lecture, perfectly ready to believe in any amount of subtly blending light and shade, any degree of crossing and commingling of political and 
religious motive, all through the period. But that the religious hopes as well as the political often took a very coarse and violent form, I regard as certain. Therefore it seems to me that, if our Lord appealed to these hopes, He could not do so without to some extent correcting them. It must not be said that in asserting this we are reading into the texts our own ideas. The teaching of the Gospels as they stand inevitably involves such correction. There will be more to be said on this subject in the next lecture.

The secret of the Kingdom is the knowledge of its laws, and the knowledge of the divine counsels in regard to it, more especially as to its nearness and the circumstances by which it was to be accompanied. Jülicher, as we have seen, and indeed many other modern critics, object to the comments which all three Evangelists make upon our Lord's teaching in parables, as though they contained something mysterious which was revealed only to the elect. It is true that there are parables, and other teaching as well, the meaning of which is plain enough. But that is by no means true of all the parables, or of all our Lord's teaching. There is a single phrase, which our Lord certainly used, and which on the face of it implies the presence of something that might be called 'esoteric' in His teaching; that is the phrase, 'he that hath ears to hear, let him hear.' This occurs twice over in St. Mark's parable-chapter-possibly not exactly at the right place (Mark iv. 9, 23). It also occurs in Matt. xi. I5, where I think we may say that it is certainly right, with reference to the identification of 


\section{Twenty Years of Research}

John the Baptist as Elijah. The whole group of ideas relating to the coming of the Kingdom and its signs was a group of mysteries.

3. Lastly, there is the secret of Suffering. On the common view our Lord is represented as from the time of St. Peter's confession onwards repeatedly predicting His own passion and death. The eschatological theory emphasizes this; but it emphasizes it too as part of a larger scheme. The so-called 'Woes of the Messiah', the great tribulation, a period of storm and stress, including persecution of the righteous, convulsions of nature, tumults and wars, were a sort of hurricane-belt that had to be passed through on the way to the end. They were the travail-pangs of the new birth.

Our Lord's predictions of the sufferings that were to fall upon Himself and $\mathrm{His}$ followers came in as a necessary part of this wider outlook of suffering. Neither is there any reason to doubt the other allusions of a like kind that are scattered up and down the Gospels.

In particular, the discourse at the sending-out of the Twelve Apostles (Matt. ix. 36-xi. I) is placed by this theory in an altogether new light. Hitherto there has been a tendency among critics to suppose that what is said about the imminence of persecution and the gift of the Spirit really belonged to another occasion. According to Schweitzer, there is no need for this supposition; we may take the chapter much as it stands. The mistake has been in regarding the whole discourse as having too much to do with instruction. The Apostles were not really sent out to teach; their 
preaching might be summed up in one word, the exhortation to repent. Their mission was to announce the near approach of the end.

But indeed Schweitzer maintains that our whole view of the ministry of our Lord has been to regard Him far too much as a Teacher. His teaching was for the most part incidental, drawn from Him by passing controversy; that $\mathrm{He}$ was really a Prophet rather than a Teacher, and, before all things, a Prophet who announced the approach of the supernatural Kingdom of God.

We are invited to look at the sequence as we have it in the Gospels. First, the Baptist comes with his cry, 'Repent ye, for the kingdom of heaven is at hand.' Then the same cry is taken up by our Lord Himself. Then, once more, He sends out the Twelve to proclaim exactly the same thing. It seemed at that moment as though the end and the new beginning were very near.

In this connexion Schweitzer offers an explanation of a phrase that has always been difficult, and the current interpretations of which must be confessed to be unsatisfactory: 'from the days of John the Baptist until now, the kingdom of heaven suffereth violence, and the violent take it by force' (Matt. xi. I 2, Luke xvi. 16). The coming of the Kingdom is an object of desire. The disciples had been taught to pray, 'Thy kingdom come.' The most effective means of hastening the coming of the Kingdom was repentance. And as a matter of fact there was a great movement of re- 
pentance all over Palestine, which brought the divine event nearer than anything else. So it was that violent men-eager, zealous, determined men-were forcing on the kingdom of God. The pressure was felt even by God Himself-the pressure of earnest desire and earnest prayer. This is the moral of the two parables of importunity - the Friend who comes at night, and the importunate Widow and the Judge. At the time when the Twelve went forth upon their mission the end seemed nearer than ever it had done before. 'Verily I say unto you, Ye shall not have gone through the cities of Israel till the Son of Man be come' (Matt. x. 23). Schweitzer insists that we must not subtract anything from the force of these words. He thinks that our Lord expected that the Twelve would never return-that the great event would come while they were still out on their mission.

In the meantime, during their absence, $\mathrm{He}$ had let drop another hint which told the same story-viz. the hint of which we have spoken, that John the Baptist was really the expected Elijah. If he was, then that meant that the winding-up of the age ( $\dot{\eta} \sigma v v \tau \dot{\epsilon} \lambda \epsilon \iota \alpha$ rov aîे $\nu$ s) had already begun.

And yet there was delay. The Twelve returned from their journeyings; and the Kingdom had not come.

Then followed our Lord's own journey to the North. This too has a new light thrown upon it. It is often spoken of as a 'Alight', due to the gathering clonds of opposition, the more and more hostile attitude of those 
among whom our Lord had preached. Schweitzer rejects this explanation, as having no sufficient warrant in the texts. He would see in it rather the impulse to seek solitude in expectation of the end. The Transfiguration is at once a ratification of the past and a foreshadowing of the future. By this time our Lord has fully realized that $\mathrm{He}$ Himself must undergo a change. As the Son of Man He must come with power from heaven. But, in order to come from heaven, He must first go thither. In other words, He must first die and rise again. The rising again is a necessary part of the transformation. But death must come first ; and $\mathrm{He}$ decided to go up to Jerusalem-to die.

Wrede, purely out of his own head, had considered himself called upon to reject this statement of the Gospels. Schweitzer, on the contrary, adheres closely to it. By this time the disciples at last understood who their Master was. But they did not know what was in store for $\mathrm{Him}$. He knew, and He set His face like a flint. When the time came, by His own direction, He entered Jerusalem in a kind of triumph. He entered it as the Messiah ; but only $\mathrm{He}$ and His own immediate followers knew that $\mathrm{He}$ was the Messiah. The crowd played its part unconsciously. It gave its greetings to the Prophet of Nazareth in Galilee; and it was in that character that it followed Him through the events of the week that followed. The full disclosure was only made to the high priest when Jesus was brought before him as a prisoner. For His presumption in making this claim Jesus was condemned, 
and went to His doom. With the cry on the Cross 'Eloi, Eloi', what may be called the eschatological envelope or clothing of the Messianic idea

'shrivels like a parched scroll'.

With that Schweitzer's outline reconstruction of the Gospel history ends almost abruptly, and with that, I think we may say in the spirit of the author, the modern phase of Christianity begins. For in another place he writes thus:-

All the history of Christianity down to the present day, all its inner real history, turns upon the delay of the Coming, on the non-fulfilment of the Coming, on the giving up of eschatology, on the progressive and self-evolving liberation of religion from eschatology (Enteschatologisierung der Religion) that goes along with it (p. 356).

And the concluding paragraphs of the book are these :-

It is well that the historical Jesus should dethrone the modern, that $\mathrm{He}$ should rise up against the modern spirit, and also that $\mathrm{He}$ should bring us, not peace but a sword. He is not a teacher and seeker, but a Master and Lord. For that reason, because $\mathrm{He}$ is all this in His innermost being. He was able to conceive of Himself as the Son of Man. That was only under the conditions of the time a name for the fact that $\mathrm{He}$ is Master and Lord. The titles with which $\mathrm{He}$ was designated as such, Messiah, Son of Man, Son of God, have become for us historical parables. We cannot find any word to express to ourselves $\mathrm{His}$ nature.

As one unknown and without name $\mathrm{He}$ comes to us, as by the shore of the lake $\mathrm{He}$ came to those 
fishermen who knew not who He was. He speaks the same words: 'But do thou follow me!' and He sets us before the tasks which $\mathrm{He}$ would have discharged in our own day. He commands: and to those who obey $\mathrm{Him}$, both wise and unwise, will $\mathrm{He}$ reveal Himself in that which in communion with Him they will have to do, to struggle through, and to suffer: and as an unspeakable mystery will they come to feel who $\mathrm{He}$ is indeed (p. 401).

I cannot say that I should be prepared to endorse all the novelties of detailed interpretation that Schweitzer puts forward; but it seems to me that, on broad, general grounds, he and his school have a great deal to say for themselves. Besides those predictions which occupy so large a place in the last week of our Lord's life, there is more in the Gospels than we are apt to suppose, which, in its original sense, is distinctly eschatological.

I must leave further comment on Schweitzer's book for the next lecture. But in the meantime I will ask you to note three things.

The author is a thorough critic--and on the critical side of his work I shall have more to say. And yet, in spite of this,

(I) He keeps much closer to the texts than most critics do ; he expressly tells us that his investigations have helped to bring out the historical trustworthiness of the Gospels ;

(2) He does not, like so many critics, seek to reduce the Person of Christ to the common measures of humanity, but leaves it at the transcendental height at which he finds it ; 
III. Tzuenty Years of Research

89

(3) By doing this, he is enabled to link on, in an easy and natural way, the eschatology and Christology of the Gospels to the eschatology and Christology of St. Paul and St. John.

I will develop some of these points next time. 
SURVEY AND CRITICISM OF CURRENT VIEWS

As the nineteenth century passed over into the twentieth the dominant influence in regard to the conception of the Life of Christ may be said to have been that of modern critical Liberalism. The great era of production in this sense had been the decade 1860-70. In I 863 appeared Renan's Vie de Fisus. A year later Strauss brought out his popular Life, which was a modified and less characteristic presentation of the results arrived at in his greater work published in 1835-6. The same year Schenkel's Charakterbild Fesu ('Portrait of Jesus') saw the light. A really greater work than any of these was Keim's Geschichte Fesu von Nazara, the first volume of which came out in 1867 , and the third and last in 1872 , and the onevolume abridgement in the same year. Written under pressure of a mortal disease, under a sense of loneliness and struggle, with a feverish energy of expression and from immense stores of genuine learning, there was pathos about it as well as power. It was a misfortune that most of Keim's presuppositions derived from literary criticism were wrong. In the meantime important critical investigations had appeared by H. J. Holtzmann (Die sy'noptischen Evangelien, 'The Synoptic 


\section{Survey and Criticism of Current Vieu's 91}

Gospels,' I 863), and K. H. Weizsäcker (Untersuchungen iib. d. evangelische Geschichte, 'Investigations bearing upon the Gospel History,' I 864). To the eighties belong two considerable works of a mediating tendency by Bernhard Weiss (1882) and Willibald Beyschlag (1885-6); while in England we had Dr. Edersheim's Life and Times of $\mathcal{F}$ esus the Messiall (1883; see p. 48 supra). In the works of the later decade, as compared with those of the earlier, there was some difference of less and more; and as the period went on the literary criticism of Holtzmann and Weizsäcker made itself increasingly felt. But the general type and character of all these works (with some exception perhaps in the case of Dr. Edersheim) was the same. The Leben Fesu of Oscar Holtzmann, which appeared just on the threshold of the twentieth century (I90I, Eng. Trans. 1904), might be taken to represent the average net result. Other smaller books by P. W. Schmidt, Bousset, Wernle, von Soden, though with rather more pointed individuality, followed substantially the same lines.

But in I90I a sharp attack was delivered against this general conception from two sides--by Wrede in a negative sense, and by Schweitzer in a more positive. Schweitzer's shorter tract, which he called Eine Skizze des Lcbens Fesu ('A Sketch of the Life of Jesus'), is taken up by his more elaborate work of last year ( 906 ). Up to a certain point in their criticism of the current view both writers go together, but Schweitzer is in this respect the more thorough. Wrede himself developed with originality principles of scepticism 
already existing; but Schweitzer challenged the methods in vogue more directly. The charges that he brings are especially those of excessive modernizing, of deserting the texts and reading too much between the lines, and of filling up gaps by a free use of speculative psychology that is incapable of proof.

I will quote a trenchant passage in which all these charges are contained. It should be remembered that all critics in a greater or less degree, and those who reject the Fourth Gospel almost entirely, are agreed in starting from the Gospel of St. Mark. It is on the treatment of this Gospel by the modern liberal school that Schweitzer comments as follows :-

In order to find its Life of Christ in the Gospel of St. Mark, modern theology is obliged in that Gospel to read in between the lines a number of things, and those constantly just the most important, and to interpolate them into the text by means of psychological conjectures. It wants to make good in St. Mark a development of Jesus, a development of the disciples, a development of the external circumstances, and it professes at the same time to be only reproducing disguised hints and ideas of the Evangelist. But in reality he has none of the pragmatism attributed to him [i. e. as I suppose, history conceived as expressing an idea], not one word of it, and when his interpreters are asked on what particular hints they rely, they turn out to be only argumenta e silentio.

St. Mark knows nothing of any development in Jesus; he knows nothing of the paedagogic considerations which are said to have determined the relations of Jesus to the disciples and to the people; he knows nothing of two forms of the Messianic idea, one spiritual and the other popular and political, contend- 
ing for the mastery in the heart of Jesus; he also knows nothing of any difference in this respect between the conception of Jesus and that of the people; he knows nothing about the ass at the entry into Jerusalem symbolizing non-political Messiahship; he knows nothing about the discourse on the Messiah as David's Son as having anything to do with that alternative; he knows neither that Jesus explained the secret of $\mathrm{His}$ own suffering to the disciples, nor that they to some extent understood it; he only knows that from the beginning to the end they were equally without understanding about everything; he does not know that the first period was a period of success, and the second a period of failure, but from Mark iii. 6 onwards he makes the Pharisees and Herodians decide upon the death of Jesus, and the people continue enthusiastic and faithful to Him down to the last day on which He preached in the temple.

All these things-and they are the foundationpillars of the modern Lives of Christ-ought first to be proved, if they are capable of proof. But it is time to stop reading them into the text as something that goes without saying, because that which according to the prevailing critical practice appears as though it went without saying, is in truth the very reverse.

Another thing that has hitherto been treated as though it went without saying-the historical kernel that it has become the custom to disengage from the paragraphs of narrative, should now be given up, until it is really shown-if it can be shown-that we are in a position to separate, and that we ought to separate, between husk and kernel. Let all that is narrated be treated as either historical or unhistorical; let us, in the case of the very definite predictions of passion, death, and resurrection, cease from taking a single hint of suffering as historical and dropping all the rest ; let us either accept the idea of an atoning death or reject it, but do not let us foist upon Jesus some 
pale and lifeless conception of the kind, while we set down to the account of Pauline theology the significance which as a matter of fact St. Mark attaches to the passion.

Different as are the results that come out from the process of getting at the kernel, the method of procedure is the same: subtraction and explaining away. 'Every historian,' says Wrede, 'ends by retaining so much of the words that have come down to him as fits in with his own construction of the facts and his own conception of historical possibilities; the rest he rejects.'

The psychological motives and psychological connexions of events and actions which it has been sought to discover in St. Mark, simply do not exist. Therefore nothing can come of it, when a construction is worked out with the help of rational psychology. Treasures without end of learning and knowledge, of art and artifice, which the Marcan hypothesis, during the two generations of its existence, has gathered into its barns with a view to base upon them its Life of Christ, are spoilt and of no further use for genuine historical inquiry (pp. 329 f.).

I am glad that Schweitzer has stated his criticisms in this very trenchant form, because in such a form they are more likely to go home; and they are very much needed. But, if one looks at them simply in order to see how far they are true, then I think we should have to confess-at least I should myself be of the opinion-that, while they contain a great amount of truth, they also contain not a little exaggeration.

Let me try to discriminate.

First, as to psychology. Schweitzer is not the only writer who thinks that we have had too much 
$I V$. Survey and Criticism of Current Views 95 psychology. ${ }^{1}$ And yet it is certainly not either possible or desirable to dispense with it altogether. All history involves a certain amount of psychological analysis. It is part of the effort to reconstruct a coherent picture of the course of events in our own minds. The picture would not be coherent if there were not a thread of psychology running through it, if there were not some conjectural connecting of actions with motives. But just because this thread of psychology comes from ourselves and not from the sources, we ought to exercise especial care in regard to it, and in particular we ought to be constantly on our guard to attribute only that kind of motive which is suitable to the time and place. We ought first to steep ourselves as far as possible in the real spirit of what is happening.

On this subject of psychology I have some retractation to make. In my article in Hastings's Dictionary, reprinted as Outlines of the Life of Clorist, I began by advocating a method which should proceed from without inwards, and not from within outwards. I was really rather repelled by the freedom with which the motives of our Lord were canvassed, as though He were a living statesman or one's neighbour in the next house. But so much has been done on these lines that is at once reverent and reasonable, and the result has been such a clear gain in reality of appre-

${ }^{1}$ Cf. Wellhausen, Einleitung, p. 94 : 'Man hat über das Selbstbewusstsein Jesu bis zum Überdruss viel geredet und geschrieben;' also Burkitt, Gospel History', p. 77: "What is certain is that our Gospels are very far from being a sort of psychological novel with Jesus Christ for Hero.' 
hension, that I would not express myself as opposed to it in principle.

To return to Schweitzer : there are many details in regard to which he seems to me to have reason on his side. I might have been tempted to include among these his protest against the view of our Lord's journey to the North as of the nature of a 'flight'. But just at the last moment there comes into my hands a very skilful re-statement of the older opinion in Professor Burkitt's new book, ${ }^{1}$ which demands full consideration. It is pointed out that the course of this journey is just such as to avoid the dominions of Herod Antipas; and from Luke xiii. $\hat{3}^{\mathrm{I}}$ we learn that rumours were abroad that Herod was meditating to put our Lord to death.

A point on which I must in any case agree with Schweitzer is that there has been too much tendency to minimize or explain away everything that is not congenial to our modern point of view. With him, I would apply this specially to the saying about the life given as a ransom for many (Mark x. 45, Matt. xx. 28). For myself, I am not satisfied with the diluted interpretation of this saying that finds so much favour.

Again, with Schweitzer, I look with some reserve upon the theories of development-not that I would wish to exclude the idea, which has taken so strong a hold upon us in modern times, but I do not think that we ought to posit development just for the sake

1 The Gospel History and its Transmission, Edinburgh, 1906. 


\section{Survey and Criticism of Current Viezus}

of development. We must not go further than we have tangible evidence for going. And it is probably true that the two periods in our Lord's public ministry should not be divided and contrasted so sharply as is sometimes done.

On the other hand, there are points of importance, and indeed affecting the whole balance of the position, in which Schweitzer seems to me to have a good deal overstated his case against the current view. One is the extent to which he questions whether our Lord really thought of Himself as a teacher (pp. 349-53). He evidently thinks of our Lord rather in the character of a prophet than of a teacher. The prophet announces, where the teacher expounds; and Schweitzer would make the preaching of our Lord consist far more of announcement than of exposition. ${ }^{1}$ In this connexion (p. 348) he would reduce the length of our Lord's ministry even to less than a year. Announcements may be compressed into a short time, where teaching would take much longer.

An opinion like this may easily appear more paradoxical than it really is. Schweitzer begins by putting aside all that incidental teaching that was drawn from our Lord by passing controversy. He would also claim as on his side everything eschatological. And it is no doubt true that there is a great deal that would really come under the head of eschatology, and perhaps seem

1 Wellhausen directly contradicts this: 'In the Galilaean period He does not announce at all, but He teaches' (Einl. p. 106). This result can only be obtained by laying the whole stress on Mark and ignoring the second document (Q), as in Matt. $x .7,23$. 
more appropriate to the prophet than to the teacher. All the parables and sayings that have to do with watching might be classed under this head; so might everything that has to do with judgement and reward; and many of the parables of the Kingdom might be described as eschatological.

Many-but by no means all. Especially the parables which form such a characteristic feature in the Gospel of St. Luke (e. g. the Good Samaritan, and the Pharisee and the Publican) would distinctly come under the head of moral teaching; so would by far the greater part of the Sermon on the Mount, and the sayings that are allied to it. Nor can we ignore the fact that our Lord is constantly addressed, both by His disciples and by strangers, as Teacher or Rabbi. The truth is that, both to His own disciples and to the multitude, $\mathrm{He}$ appeared at once as teacher and prophet. $\mathrm{He}$ is addressed almost indifferently now as the one and now as the other. We need to take accoùnt of both sides of $\mathrm{His}$ mission, if we are to form an adequate conception of it. ${ }^{1}$

If we are to allow for teaching as well as prophetic announcement, we shall require a greater length of time : and the data seem to me to point in this direction. No doubt the question as to the duration of our Lord's ministry depends ultimately upon the extent to which we adopt the time-references in the Fourth Gospel. But there are some other indications that seem to favour the longer period. Such, for instance, would be the parallelism between our Lord's ministry

${ }^{1}$ Cf. Bousset, Jesus, pp. 2 I-33 (E. T.). 


\section{Survey and Criticism of Current Views 99}

and the career of the Baptist. First, there is the time during which they were working near each other. This, it is true, comes from the Fourth Gospel, but seems to be intrinsically probable. Then there is the Baptist's imprisonment, which cannot have been very short, as we have to make room both for his interviews with Herod Antipas, and also for reports to reach him and doubts to arise in his mind about the mission of our Lord. And then, after his death, we must again allow a substantial interval before Herod could conceive the idea that our Lord was the Baptist risen from the dead. This would not follow quite immediately. And lastly, there is the withdrawal of our Lord to the Nortl, which Professor Burkitt (p. 93) estimates as extending over some eight months.

Another paradox of Schweitzer's to which I cannot assent is the double contention (i) that there was no political element in the Messianic expectation of the Jews; and (ii) that our Lord had not in consequence to recast and transform the Jewish idea. It is difficult to understand exactly what Schweitzer can mean by the first of these denials. I do not think that he has ever quite explained his own meaning. Surely there was a large political side to all the Jewish eschatology. It arose in the first instance out of the Old Testament doctrine of the 'Day of the Lord'. This was to be primarily a day of judgement upon the enemies and oppressors of Israel. It was only as a second step, due directly to the teaching of the prophets, that it came to be regarded as a judgement upon Israel itself. The old idea was never repealed; and there was no 
belief that glowed more fiercely in the breasts of the Jewish people. Josephus says almost in so many words that it was the Messianic hope which excited the people to break out in the Jewish war. He himself discreetly explained that hope as fulfilled in Vespa$\operatorname{sian}(B . \mathcal{F}$. VI. v. 4).

I am aware that Schweitzer prides himself on the logical thoroughness of his theory, and that he regards this thorough-going logic as essential to it. But it seems to me that, in order to carry out this, he has to ignore a good many well-attested facts. I believe it to be, on the whole, as great a mistake to try to explain everything in the Life of our Lord in terms of eschatology, as it is to treat the eschatology as a mere appendage.

To the wider aspect of the acceptance of the Jewish eschatology by our Lord I shall return later on in this lecture. In the meantime I would point out that the general effect of the theory, where it is soundest, is to heighten our sense of the historical trustworthiness of the Gospels. For instance, at the end of the discussion about the title 'Son of Man', Schweitzer writes :-

We must needs remark in regard to this early period the fidelity of the tradition. The evangelists who wrote in Greek, like the Greek-speaking Churches, can have hardly understood any longer the purely eschatological character of this name by which Jesus described Himself. It had become for them nothing more than a name. And yet they, and in particular St. Mark, handed down the sayings of Jesus in such a way that the original meaning and application of the 


\section{$I V$. Survey and Criticism of Current Viezus IOI}

expression as used by Him is still clearly discernible by us, and we can accordingly fix with certainty the isolated cases in which the title holds a secondary place in the text of His discourses. And so the use of the expression 'Son of Man', which, if we were to join in the tour de force of Lietzmann and Wellhausen and strike it out as interpolated by Greek theology, would throw doubt upon the whole evangelical tradition as such, is exactly a proof of the sureness and trustworthiness of this tradition. We may say generally, that the progressive recognition of the eschatological character of the teaching and acts of Jesus denotes a progressive vindication of the evangelical tradition; a whole series of sections and discourses that were challenged, because from the standpoint of modern theology taken as a test of the tradition they seemed without meaning, are now assured. The stone of critical stumbling has become the corner-stone of the tradition (pp. $282 \mathrm{f}$.).

And there are many other passages to a like effect.

I cannot, however, say that on this subject of the historicity of the Gospels Schweitzer is quite consistent. All along the line of his own theory and his own personal investigations the result is such as I have just clescribed. But in his history of research as applied to the Gospels he seems to use a rather different standard. In the broad outline of his survey he marks off three main stages: the first dating from Strauss in the year 1835; the second from Holtzmann and his companions Schenkel, Weizsäcker, and Hase from i 863 onwards; and the third from Johannes Weiss in the year I 892. The last of these periods has for its chief characteristic the thorough application of eschatology. The first period is regarded as practically settling the 
question of Miracles, and the second as in like manner practically settling the question of the Fourth Gospel.

Schweitzer does not say that the problem of Miracles is solved; he expressly guards himself against saying this (p. I09). He thinks that we shall never be able to say how the narratives arose and assumed the form they bear; he would simply leave them with a note of interrogation. But his view is that from the time of Strauss onwards historical science has practically left miracles on one side.

The criticism of Strauss was directed at once against Rationalism and Supernaturalism. It was more completely hostile to the former than to the latter (pp. Io4f.). But, as Schweitzer rightly sees, it requires something different from both, indeed a new way of conceiving the Supernatural. I would not at all say that Schweitzer has completely succeeded in defining this new conception. That is probably the last thing that we shall any of us be able to do. Schweitzer's language is not, I think, always consistent with itself; it leans sometimes to the destructive side more than upon his own premises it ought to lean. On the other hand his affirmations are sometimes vaguer than they need be. Still I cannot withhold from him the praise due to a courageous attempt to solve a difficult problem. But, as the subject is discussed at greater length elsewhere in these lectures and in the present book, I will not pursue it further at present.

In regard to Miracles, I could wish that Schweitzer had given rather more prominence to his warning 


\section{Survey and Criticism of Current Views $\mathrm{1} 03$}

against premature modernism. I quite agree that we are compelled to modernize sooner or later. We are modern men; and when we come to the final appropriation and assimilation of ancient truth, we must appropriate and assimilate it as modern men. But we are apt to be in too great a hurry to get to this stage. We intrude our modernism too soon. We mix it up with the statement of ancient facts and the reproduction of ancient thought. It is far better to keep the two things separate-at least long enough to enable us to see the ancient facts and ancient thought in the full impressiveness of their own context.

And yet, when all is said, I doubt whether we shall be able to find a much better description of the attitude of many a loyal Christian than to say that he accepts the narratives of miracles and of the miraculous as they stand, but with a note of interrogation. If I might put it in my own way, I think I should clescribe it as 'a note of interrogation-in brackets and in the margin'. By this I mean, a question that distinctly does not touch the essence of the matter. We believe, indeed we are sure, that virtue went forth from the Person and presence of the Lord. But it is another thing to adjust exactly our conception of the mode in which it went forth to language that took shape more than eighteen centuries ago under conditions of thought and experience very different from our own. Such a marginal note as I have suggested will allow suffciently for this difference, without implying any real disloyalty. And even a modern mind may be content with so much reserve until its instruments are 
sharpened to a finer edge of discrimination than they are at present.

As to most of the evangelical miracles Schweitzer contents himself with registering the explanations that from time to time have been given, without adopting them. But there is one central miracle in regard to which he puts forward a view of his own that is at least extremely interesting. This is the miracle of the Feeding of the Five Thousand.

In this (he says) everything is historical, except the concluding remark, that they were all filled. Jesus caused the food, which $\mathrm{He}$ and $\mathrm{His}$ disciples had with them, to be distributed among the multitude, so that every one of them received a little, after $\mathrm{He}$ had first pronounced a thanksgiving over it. The significance lies in the thanksgiving and in the fact that they received food consecrated by $\mathrm{Him}$. As $\mathrm{He}$ is the coming Messiah, this meal, without their knowing it, becomes the Messianic meal.

It will be remembered that the Messianic meal, or banquet, held a definite place in the Jewish expectation, on the strength of Isa. lv. I ff., lxv. I $2 \mathrm{ff}$, and especially xxv. 6-8: 'In this mountain shall the Lord of hosts make unto all peoples a feast of fat things, a feast of wines on the lees, of fat things full of marrow, of wines on the lees well refined,' \&c. It is certainly in allusion to this that St. Luke represents our Lord as saying at the Last Supper: 'I will not drink from henceforth of the fruit of the vine until the kingdom of God shall come'; and again, 'I appoint unto you a kingdom, even as My Father appointed unto $\mathrm{Me}$, that ye may eat and drink at $\mathrm{My}$ table in 


\section{Survey and Criticism of Current Views 105}

My kingdom' (Luke xxii. 18, 29 f.). Schweitzer regards the Last Supper as a foretaste of the Messianic feast. He goes on, with reference to the feeding by the Sea of Galilee :-

With the portion of bread which $\mathrm{He}$ causes to be distributed to them by the disciples, He consecrates them to be partakers in the coming Messianic feast, and gives them the guarantee that, as they had been His table-companions in the time of His obscurity, so should they be also in the time of His glory. In the thanksgiving, He not only gave thanks for the food, but also for the coming kingdom and all blessings. It was the counterpart of the Lord's Prayer, where He so remarkably inserts the petition for daily bread between the petition for the coming of the kingdom, and for preservation from temptation [or trial, which Schweitzer explains of the trials which would accompany the first stage in the coming of the kingdom]. The feeding was more than a love-feast and feast of communion. It was, from the standpoint of Jesus, a Sacrament of deliverance (p. 373).

Schweitzer explains both the Sacraments in an eschatological sense. Just as the one is a foretaste of the Messianic feast, so also the other carries out the idea of the sealing of a peculiar people, after the manner of Ezek. ix. $4 \mathrm{f}$.: "And the Lord said unto him, Go through the midst of the city, through the midst of Jerusalem, and set a mark upon the foreheads of the men that sigh and that cry for all the abominations that be done in the midst thereof. And to the others he said in mine hearing, Go ye through the city after him, and smite : let not your eye spare, neither have ye pity.' Baptism was a sign of deliver- 
ance by which the Lord 'would know them that are His' in the judgement that was to come. Schweitzer is quite right in saying that this is the conception that prevailed throughout the Early Church. I am sorry to be obliged to abridge this account of his views, but they are full of interest. They will be found on pp. 373-8.

We might naturally have supposed that, taking the view that he does of the Feeding, Schweitzer would see in it a mark of the authentic character of the Fourth Gospel, which puts a very similar construction upon it in the discourse in the synagogue at Capernaum. But I am afraid that in regard to the Fourth Gospel he simply accepts the conventional view current in German liberal circles. That there is a great deal that is purely conventional in this view, I have tried to show elsewhere. ${ }^{1}$ Schweitzer only repeats what has been said, without testing it.

The question will no doubt be raised how far the Fourth Gospel is compatible with any eschatological theory at all. But this is just one of the things in regard to which an impression exists that will not bear examination.

Of course we have to remember that the Fourth Gospel was written at a time when the expectation of the end which had been so strong and vivid in the earlier years of Christian history was comparatively in abeyance. The Fourth Gospel is at a level similar to that of the later Epistles of St. Paul, and not the earlier. But, this being so, it is remarkable how much there

${ }^{1}$ Criticism of the Fourth Gospel (1905), p. I30. 


\section{Survey and Criticism of Current Views 107}

is in the Fourth Gospel of eschatological language and the eschatological mode of thought. For instance this :-

Verily, verily, I say unto you, The hour cometh, and now is, when the dead shall hear the voice of the Son of God; and they that hear shall live. For as the Father hath life in Himself, even so gave $\mathrm{He}$ to the Son also to have life in Himself: and $\mathrm{He}$ gave $\mathrm{Him}$ authority to execute judgement, because $\mathrm{He}$ is the Son of Man. Marvel not at this : for the hour cometh in which all that are in the tombs shall hear His voice, and shall come forth; they that have done good, unto the resurrection of life; and they that have done ill, unto the resurrection of judgement (John v. 25-9).

We observe here that our Lord speaks of the Messiah, under the titles Son of God and Son of Man, objectively in the third person, just as $\mathrm{He}$ is represented as doing in the Synoptic Gospels. And the function of Judge ascribed to $\mathrm{Him}$, as well as the idea of bodily resurrection, is in accord with the tenor of all eschatological teaching.

The use of the title Son of Man is also strictly eschatological. I shall return to this at some length in the next lecture, and will not dwell upon it now. St. John's use of the title is in agreement with the best views that are coming to be held about it. The Jews say: "We have heard out of the law that the Christ abideth for ever : and how sayest Thou, The Son of Man must be lifted up? Who is this Son of Man ?' (xii. 34). The use in the third person and the question are exactly as they should be. So also is that other question put by the crowd: 'How long dost Thou 
hold us in suspense? If Thou art the Christ, tell us plainly' (x. 24). Clearly, in spite of some appearances to the contrary, the evangelist was quite aware of the reserve with which our Lord had put forward His claim.

With clue allowance for the special conditions (date and purpose) of the Fourth Grospel, I do not think that we shall find it really opposed to Schweitzer's main theses. I imagine that the opposition to these will rest rather upon two grounds: (1) the reluctance to implicate our Lord in the fantastic imagery of the Jewish apocalypses; and (2) the reluctance to ascribe to $\mathrm{Him}$ a kind of outlook which in a literal sense is unfulfilled, or, in other words, the difficulty of correlating this apocalyptic outlook with the actual course of Christian history.

The reluctance in both cases is natural, and yet I believe that it may be easily carried too far. On the other hand, although I admire Schweitzer's unflinching realism, and although I would not blame him for pushing this to the verge of paradox, still it seems to me that he has made his case more difficult than it need be by exaggeration, and by stopping short when he might have gone forward in the process of reconstruction.

Speaking broadly and with much reserve as to details, I should be disposed to defend the main outlines of his argument. I consider that we want more, and not less, of realism in our understanding of the New Testament. We should accustom ourselves to the recognition of a large acceptance on the part of 
IV. Survey and Criticism of Current Views 109

our Lord of the ideas that $\mathrm{He}$ found in existence all around Him. We should in each case start from the sense in which those ideas were understood by $\mathrm{His}$ contemporaries. And not until we have thoroughly searched and sounded this sense should we turn to look for another.

But, on the reverse side, we also must not stint our recognition of the extent to which, in the very act of adopting and using these ideas, our Lord really remoulded and transformed them. And, most of all, we must beware of withholding this recognition at the bidding of certain tacit humanitarian presuppositions, which I suspect are present in Schweitzer's book to a greater degree than he is himself aware.

Let me give one or two examples of what I mean: first, from the non-apocalyptic portion of the Gospels, and then from the apocalyptic.

In the Preliminary Lecture I discussed at some length three marked examples of our Lord's method of dealing with the figurative language and ideas inherited from Judaism; and I may perhaps be allowed to refer summarily to what I then said.

The first example was taken from the account of the Temptation. I have always contended that this is one of the most authentic things in the whole of the Gospels ; and that for the reason that it lies so entirely beyond the reach of invention. Neither any one of the original disciples, nor the primitive Church as a body, had insight enough to invent it. That means that the story must ultimately have come from our Lord Himself. 
Now the first thing that strikes us in this story is the extreme simplicity-what we might call the vernacular simplicity-of the outward form. The story is told as a Jewish mother might have told it to a Jewish child. The Power of Evil is represented in a personal bodily form, and the machinery or setting of the story is full of the marvellous-locomotion through the air to impossible positions and with impossible accompaniments, such as the literal view of all the kingdoms of the world in a moment of time. These celestial journeys, I have little doubt, were suggested by the book of Ezekiel, where the prophet is transported by the Spirit from place to place; which means that he was empowered to see in vision and to describe what was going on in those places.

Realism could hardly go further. And yet the meaning and essence of the Temptation is wholly spiritual ; it is the problem what is to be done with supernatural powers; shall the possessor of them use them for his own sustenance, or for his own aggrandizement? In what way is the kingdom of God to be spread and established?

A second illustration was taken from the apocalyptic cycle. I have referred to it already in this lecture, but I shall not hesitate to quote the verses again, because, if I mistake not, they are of profound significance for the understanding of our Lord's method. 'All the prophets and the law prophesied until John. And if ye are willing to receive it, this is Elijah, which is to come. He that hath ears to hear, let him hear' (Matt. xi. I $3-15$ ). 
Here again I do not doubt that the popular idea was a crude one. It was thought that Elijah would literally rise from the dead, and resume his prophetic work in preparation for the coming of the Messiah. That was what the Scribes meant, when they said that Elijah must first come ; and that was the kind of crude sense in which Herod Antipas declared our Lord to be the Baptist risen from the dead. But, because the idea was crude, our Lord did not therefore discard it. $\mathrm{He}$ took it as it was, but He applied it in a sense that has about it nothing of crudity. He applied it to His own real forerunner, who had indeed come 'in the spirit and power of Elijah' (Luke i. I7). It was by $\mathrm{H}$ is Divine pronouncement-by a word, and only by a word-that the Baptist became Elijah.

The third example was our Lord's greeting to the Seventy when they returned from their mission and reported that even the devils were subject to them. On this our Lord said, 'I beheld Satan fall as lightning from heaven' (Luke x. I8). This too is apocalyptic language: it belongs to the same category as the description of Satan being bound and cast into the lake of fire in the Revelation of St. John. That, it might be said, is Jewish and fantastic; but the meaning of our Lord was not at all fantastic. What $\mathrm{He}$ meant was that the victory over the Power of Evil was virtually won. The healing of those few demoniacs might seem a small thing; but it was not a small thing; it was really a crisis - the crisis in the history of the human race.

We may take this last instance as typical of the 
whole way in which our Lord adopted, and in adopting transmuted, the apocalyptic tradition. When we begin to read the Gospels systematically with a view to see how much of their language really belongs to this tradition, we shall probably be surprised at its amount. And then, we begin to ask ourselves, in what relation does it stand to the history of the primitive Church?

Happily for us, the problem which is becoming urgent for ourselves presented itself also to that age of the Church, and had to be solved by its leaders. Nothing can be more instructive than the way in which they dealt with it. One of the clearest proofs that our Lord's teaching must have been largely eschatological is supplied by the fact that after the Ascension the attitude of the Church is so predominantly eschatological. Not only do we find, when we really look into it, that the early chapters of the Acts presuppose an attitude of this kind (Acts i. 11, ii. 16-2I, 36-40, 47, iii. I 8-2 I, 26, iv. 2, I I, I 2, v. 31, 32, vii. 56), but-what is more significant-when the curtain rises in the form of strictly contemporary literature some twenty years or a little more later, the Church is still in the same attitude. Both 1 and 2 Thessalonians are essentially eschatological. In I Thess. i. 9, I0, we have a summary description of the newly-founded Church, which had so lately 'turned unto God from idols, to serve a living and true God, and to wait for His Son from heaven, whom He raised from the dead, even Jesus, which delivereth us from the wrath to come'. In like manner the Church at Corinth is 


\section{$I V$. Survey and Criticism of Current Views I 3}

addressed as waiting for the revelation of our Lord Jesus Christ; who should also confirm them unto the end, that they might be unreprovable in the day of our Lord Jesus Christ (I Cor. i. 7, 8). A little later, in the same Epistle, we have a vivid description of what this 'waiting' meant: 'But this I say, brethren, the time is shortened, that henceforth both those that have wives may be as though they had none; and those that weep, as though they wept not; and those that rejoice, as though they rejoiced not; and those that buy, as though they possessed not; and those that use the world, as not abusing it: for the fashion of this world passeth away' (vii. 29-3I). And the parting words of the Epistle (xvi. 22) are, 'Maran atha'-the Christian greeting, 'Our Lord cometh.'

From such indications as these it is not difficult for us to form for ourselves a picture of the attitude-the deliberate and prevailing attitude-of the Church about the years $50-56 \mathrm{~A}$. D. It is, I think we may say, in entire agreement with the other picture that we frame for ourselves from data contained in the Gospels. If our Lord used the language that $\mathrm{He}$ is represented to have used, then the attitude of the Church for the first twenty-five or thirty years of its history is easily and naturally explained. The rest of the century witnessed various fluctuations of feeling; sometimes the expectation appeared to be weakened, but only to break out with redoubled force, as at the time of the Jewish War and towards the end of the reign of Domitian, when we see it in full eruption in the book of Revelation. After that the expectation again began to decline, RECON, 
lingering on as the shadow of its former self among the Chiliasts or Millennarians.

But what had happened in the meantime? Behind the screen (so to speak) of eschatology the Church had gradually been building up for itself an organized body of thought, the imposing structure that we call its Theology. We can follow the process even now in the great Epistles of St. Paul. But there is evidence enough that according to the measure of their power other leaders of the Church had been doing the same thing. The Pauline Churches were not the whole Church, neither was Pauline Christianity the whole of Christianity. Not to appeal to examples that might be questioned, the Epistle of St. James and the book of Revelation represent the conspicuous and energetic expression of non-Pauline belief.

But the main question that we have to ask ourselves is, in what relation does the broad development of the Church in the first two generations of its history stand to the ministry and teaching of Christ Himself, and especially to that ministry and teaching regarded in the light of eschatology? In particular, what relation does the subsequent development bear to our Lord's own outlook beyond the tomb-that tomb of $\mathrm{His}$ which was filled for a brief space, but so soon found empty?

This last form of question is one that I shall not attempt to answer directly. When we get on to the ground of the ultimate consciousness of our Lord Jesus Christ we must restrain our words and not speak as though we knew more than we do. But we 
may take definite language used, and compare it with the facts.

Here is a salient passage which I will take in its oldest and best attested form: 'Verily I say unto you, There be some here of them that stand by, which shall in no wise taste of death, till they see the kingdom of God come with power' (Mark ix. I). What is the essential meaning of the kingdom of God? Is it not the asserted and realized sovereignty of God, Divine influence and Divine power felt as energizing in the souls of men? Is not this the eternal reality-as distinct from any temporary expression-of what we mean by the phrase? But what, again, is that, when we look at it closely, but the apostolic doctrine of the Holy Spirit? And, if we ask further at what point in history did a new access of this Divine power and energy enter into the world, shall we not say, from the Day of Pentecost onwards? We still pray, Thy kingdom come. And Christians from the first have in like manner prayed for its coming all down the centuries. There has been, and still is, a real Coming; and yet we feel that the Coming has never yet been exhausted; in its plenitude it is still far off. ${ }^{1}$

1 There is a good passage to like effect in Julius Kaftan, Jesus $u$. Paulus (1906), p. 23 f.:-' From this purely historical point of view there are two factors of which we have to take account. First, there is the cycle of apocalyptic ideas, from which are taken the root conceptions of the preaching of Jesus-the Kingdom of God and the Messiah, the forgiveness of sins and redemplion. In the second place, there is the spiritual force in Jesus Himself, by virtue of which through an inward necessity of His being He knows Himself to be the Messiah, the Son of the Father. Out of the tension between these hwo 
It is perhaps easiest for us to apprehend this if we adopt for the moment the impersonal phrase, and speak of the kingdom or sovereignty of God coming with power. But the meaning is not different if we employ the other more personal form and speak, with St. Matthew, of the Son of Man coming in His kingdom.

The apostolic doctrine undoubtedly was that the coming of the Holy Spirit was a coming of the Son. This is the very clear teaching of St. Paul (Rom. viii. 9-11), and it is also the teaching of St. John. 'A little while and ye behold $\mathrm{Me}$ not, and again a little while and ye shall see Me.' 'I will not leave you orphans, I will come to you.' 'But the Comforter (or Advocate), even the Holy Spirit, whom the Father will send in My Name, He shall teach you all things, and bring to your remembrance all that I said unto you'

factors the preaching of Jesus arose. All attempts to reduce it to a single rule, or to force it upon the horns of a dilemma between which a choice must be made, break down in face of the facts. In particular, we must not ask whether the kingdom of God and the Messiah are future or present, in order to take this for our guide in one sense or the other. Everything is yet future, because all must see that the existing order of things, the aìv oivos, still prevails. For the apocalyptic conceptions in the mouth of Jesus are not to be understood symbolically or as a form of words (Einkleidung), but realistically. [Is it necessary to oppose "symbolical " and "realistic" in this way? May not an idea be realistically expressed-i.e. expressed through some strongly material forms, and yet be in the last resort symbolical?] And yet everything is already present; the Bridegroom has come; the Son of Man has appeared among men. Only a paradoxical formula can cover the actual historical facts. And that must run thus: The future salvation has become present, and yet has not ceased to be future.' The italics are Kaftan's. 


\section{Survey and Criticism of Current Viezus I 7}

(St. John xvi. 19; xiv. 18, 26). This is really the teaching of Romans viii; and then, from Rom. viii the transition is easy to Rom. xiv. 17: 'The kingdom of God is not eating and drinking, but righteousness and peace and joy in the Holy Ghost.' The kingdom of God is here closely associated with the gift of the Holy Ghost; and it is a present kingdom. In like manner, it is of a present kingdom that the Apostle speaks, when he says that 'the kingdom of God is not in word, but in power' (I Cor. iv. 20). It is also a present kingdom into which Christians are already 'translated' (Col. i. I 3). And yet the A postle speaks none the less of the kingdom as future, as something to be inherited (I Cor. vi. 9, IO; xv. 50; Gal. v. 21 ; Eph.v. 5) and reserved for the elect (2 Thess. i. 5 ; 2 Tim. iv. I8), as something that will be grander and more perfect than it is now (I Cor. xv. 24; 2 Tim. iv. 1).

Both writers are really describing the facts of their own day. They are describing the new force that they felt had entered into the world; a force of which St. Paul had had no experience when he was a Pharisee. It was a force that both writers were conscious had come down from heaven. It came from that abode whither Christ had gone; it was a direct continuation of His work; and yet the future might see it more triumphant than ever.

When, in the light of these things, we look back upon such a passage as St. Mark ix. I, I cannot help asking if it is not possible that the coming of the kingdom of which our Lord spoke at least included 
within its scope that great wave of energy and enthusiasm which dated from the day of Pentecost? The prophetic language, even of our Lord Himself, is couched in parables which we must not always expect to be able to reduce to plain prose. It would certainly be wrong to assume that He meant nothing more than His contemporaries might have meant by the same words. But in a case like this, which relates to the fulfilment of prophecy in history, the problem is to determine, not only what the Son meant, but what the Father meant, speaking through the Son ${ }^{1}$ :

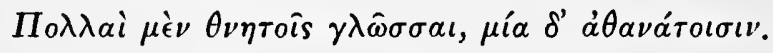

1 This point is more fully developed below (pp. 198-200). 


\section{V}

TIE DEITY OF OUR LORD JESUS CHRIST AS EXPRESSED

IN TIIE GOSPELS

In the three preceding lectures I have been trying to put before you what I may call the eschatological theory of the Life and Teaching of our Lord : first, to trace its history, and the steps by which it has come to the front: then to expound and, in expounding, also partly to criticize it.

Speaking very summarily, the theory-or so much of it as most demands our attention-is something of this kind.

Although our Lord, at least from the Baptism onwards, had the clear consciousness that $\mathrm{He}$ was Himself the promised Messiah, yet $\mathrm{He}$ did not at once press His claim, but deliberately sought rather to conceal than to assert it. Although $\mathrm{He}$ was the Messiah, the time for entering upon His full Messianic functions was not yet. The Kingdom of God, which the Nessiah was to inaugurate, was not as yet present but future. The announcement with which our Lord began $\mathrm{His}$ ministry repeated exactly the announcement made by the Baptist: it was not 'The kingdom of God is here', but 'The kingdom of God is at hand'. The petition in the Lord's Prayer is also future: 'Thy 
kingdom come'. The kingdom thus intended was not merely an increased activity of Divine working conducted through the ordinary natural channels, but a supernatural divine activity, such as the Jews expected at the close of the existing aeon or world-age. As being supernatural, it was necessarily not present, but future. This was the sense in which our Lord preached the Gospel of the Kingdom. His public ministry, as we look back upon it, was not the establishment of the kingdom, but a stage preliminary to its establishment. The real inauguration of the kingdom was to take place when the Messiah came to His own in declared supremácy. The precautions which our Lord took to prevent a premature disclosure of the Divine counsels were successful. Only His most intimate disciples guessed the secret, and even they not until His ministry was far advanced, when St. Peter, acting as their spokesman, rose to the confession that his Master was the Christ. The people at large knew that Jesus of Nazareth was a prophet, and they had a sort of uneasy feeling that $\mathrm{He}$ might be more; but not until our Lord assented to the interrogation of the high priest did He Himself publicly and categorically affirm His own Messiahship.

Before $\mathrm{He}$ did this, $\mathrm{He}$ already knew and had already foretold that $\mathrm{His}$ present condition must come to an end, and a great change intervene before the consummation could come. The coming of the Messiah with the clouds of heaven was not to be confused with the earthly mission of Him who had not where to lay His head. Before $\mathrm{He}$ could come from heaven, $\mathrm{He}$ 


\section{$V$. The Deity of Christ in the Gospels}

must first be transported thither. He must needs die; and $\mathrm{He}$ must needs rise again; it was through the grave and gate of death alone that $\mathrm{He}$ could enter upon $\mathrm{His}$ full Messianic inheritance.

I am free to confess that in the theory, thus broadly stated, there seems to me to be a large element of truth, and of what I suspect for most of us will be new truth. I doubt if we have realized-I am sure that I myself until lately had not adequately realized-how far the centre of gravity (so to speak) of our Lord's ministry and mission, even as they might have been seen and followed by a contemporary, lay beyond the grave. I doubt if we have realized to what an extent He conceived of the kingdom of heaven, that central term in His teaching, as essentially future and essentially supernatural. I doubt if we have quite understood the reticence and reserve with which our Lord put forward His own claim, though the claim was there, or rather the consciousness on which it was based, all the time. I doubt if we have appreciated the preliminary or preparatory character of His mission; the gradualness of the disclosures made in the course of it; in particular, the 'mysteries' or secrets which were an important part of His teaching-the mystery of the Nessiah, the mystery of the Kingdom, the mystery of Suffering. I doubt if we have recognized the extent to which our Lord, while transcending the current Jewish notions of the time, yet in almost every instance starts from them.

One main argument for such a construction of the Gospel History as I have been describing seems to 
me to be the way in which it fits in with the attitude of mind that we find prevailing in the Early Church, when the curtain rises and we get our first contemporary pictures of it.

And if I am asked further, as to the transition from an eschatological way of looking at things to a noneschatological, I would reply that we can nowhere see it better carried out than in the writings that have actually come down to us from the Apostolic age, and that I fully believe were in the main working out hints and intimations of our Lord Himself. I also think that we have evidence enough that our Lord's own teaching was deeply symbolical and that, if we did but know, the ultimate reality would be found to correspond more nearly to the actual historical course of events than we are apt to suppose. I am inclined to believe-though this is speculation, that I would not express otherwise than very tentatively-that the real coming of the Kingdom - the fact corresponding to it in the field of ultimate realities-is what we are in the habit of calling the work of the Holy Spirit, from the day of Pentecost onwards; the presence of a divine force, drawing and annexing (so far as the resistance of human wills allows it) the world to itself, but as yet still in mid process, and with possibilities in the future of which we perhaps hardly dream.

With this much of retrospect, I pass on to the subject of this, my last lecture, which singles out what for us Christians must needs be the central point of interest in the whole construction, the place in it that 
we are to assign to our Lord Jesus Christ Himself. The problem still turns round the use of those old names-Son of Man, Son of God, Messiah.

In regard to all three, I think that we stand on firmer and clearer ground than we did. I am speaking not so much of the state of things in this country as in the world at large, and more particularly in Germany, and not so much of the actual balance of opinion as of what we can ourselves digest and make our own. Speaking in this sense, I should say that we have passed through a period of keen criticism. Some searching questions have been raised, which I think we may now more or less definitely put behind us. We have seen how doubts have been thrown, on linguistic grounds, upon the use by our Lord of the title Son of Man with reference to Himself. We have seen how those doubts have receded; and I do not think that they will ever be urged with so much insistence again. Even if we are to take the phrase 'son of man' as an Aramaic equivalent for 'man', it would by no means follow that our Lord cannot have applied it to Himself.

I am no Semitic scholar; but there is just one point that I should like to submit for consideration, and which I do not remember to have seen noticed. The point of the linguistic argument was that, in the Aramaic phrase, 'son' has so far lost its force that the phrase as a whole meant no more than simply 'man'. Now we know that in the book of Ezekiel 'son of man' is the standing phrase by which the prophet describes himself. That is no doubt Hebrew, 
and not Aramaic. But, in a people so devoted to the Bible as the Jews, it was impossible that a usage so marked as this could be forgotten. Whatever degradation the phrase may have undergone in common speech, the Biblical use must at any time have been capable of being revived as a mode of address. The Jews knew their Bibles so well that there can never have been anything really strange in it. This general argument seems to me to come in to reinforce the conclusion at which I believe Aramaic scholars had arrived that, even if we do take the phrase as meaning little more than 'the Man', exception cannot be taken to the use ascribed to our Lord in the Gospels.

In any case it must have been difficult to sustain the objection. The phenomena that the Gospels present in regard to this usage are remarkable, and deserve to be dwelt upon in some detail. Let me first remind you of the statistics. The phrase 'Son of Man', in the mouth of our Lord, occurs I4 times in St. Mark, 30 times in St. Matthew, 25 times in St. Luke, and 12 times in St. John. Naturally, the two longest Gospels have the greatest number of occurrences. But the student of the Synoptic Problem sees at a glance something more than this. He sees at once that the phrase occurs with considerable frequency in both of his leading documents;-in the Mark-gospel probably about i4 times (8 Mk. Mt. Lk. +5 Mk. Mt. + I Mk. Lk.), in the Logia or non-Marcan document at least 8 times. Besides these, it occurs 9 times in special matter of St. Matthew, and 8 times 


\section{$V$. The Deity of Christ in the Gospels}

in special matter of St. Luke. Not all of these instances need necessarily come from a peculiar source, but the majority probably do so. In addition to this there are the occurrences in St. John, and one in an extant fragment of the Gospel according to the Hebrews. In other words, we might say that the phrase is found in practically every document that criticism has to postulate. More strictly, I should have said, in every evangelical document; for the remarkable thing is that it occurs hardly anywhere in other writings than Gospels. There is, as is well known, one solitary example in the Acts (vii. 56), not one in the whole body of Epistles, and two-where the ultimate reference is probably to Dan. vii. I3-in the Apocalypse. The phrase is equally rare in early Christian literature outside the Canon; and it is worth while to notice that, in the Gospels, it is always put into the mouth of our Lord Himself, and is never used by the evangelists in their own persons.

Let me invite your attention to these surprising literary phenomena. They seem to me, and have always seemed, to throw a vivid light on the high character for trustworthiness of our Gospels. It is often argued that particular expressions or ideas come from St. Paul, or from the theology of the Early Church. Here is an expression that certainly does not come from either; the evidence for it in any such connexion is infinitesimal. Really, it can only go back to our Lord Himself, and it bears speaking testimony to the fidelity with which $\mathrm{His}$ words have been preserved. 
And now, further, what is the meaning of the title? Let us recall its history. We begin with the vision in Dan. vii. The prophet has been following the fate of the four great world-empires, the Babylonian, Median, Persian, and Greek, each impersonated under the form of a beast of prey-the first like a lion, the second like a bear, and so on. One by one they are brought before the throne of Divine Judgement, and one by one they are condemned and deposed. Then a fifth figure comes before the Almighty, "like unto a son of man,' i. e. like a man. This Figure, we are told, stands for the 'saints of the Most High' (ver. 18), i.e. the purified and regenerate Israel. This manlike Figure also receives a kingdom, which is not only for a time but eternal.

The next writing in which any such impersonation appears is the Book of Enoch (xlvi-xlviii, lxii, lxix, lxx). This time the manlike Figure is no longer the collective Israel, but the personal Messiah. For a Jew, that was an easy transition of thought, of which we have many examples. From the Similitudes of Enoch onwards all the allusions to the Son of Man are Messianic: so not only in Christian sources but in 4 Ezra xiii. $3 \mathrm{ff}$.

Still, the title was not, I believe, very widely current. It does not appear in the Rabbinical writings proper. The apocalyptic teaching, though its main outlines were well known, had about it something esoteric. And that, I conceive, was one of the reasons that recommended the title to our Lord. We have seen that a great part of the time when $\mathrm{He}$ 
spoke of the Son of Man His hearers probably did not understand that He was speaking of Himself.

But I believe that there was another reason; and on this I should like to lay a little stress, because I do not think that it has had the prominence that it deserves.

I believe that our Lord rarely took up a Jewish idea without putting into it more than $\mathrm{He}$ found there. And this enrichment constantly came from His profound intimacy with the Old Testament. I believe that we should at any time be justified in supposing that at least the leading passages in which a phrase that He makes use of occurs were present to His mind. But, apart from such general presumption, we have evidence that $\mathrm{He}$ appealed to Psalm viii in His quotation of the verse, 'Out of the mouth of babes and sucklings Thou hast perfected praise' (Matt. xxi. I6). And we also know that in the apostolic age this Psalm was quoted as Messianic (Heb. ii. 5-9, an elaborate and important passage, in which I would ask you specially to note how the writer glides into the subject of suffering; comp. I Cor. xv. 27). This fact seems to me to raise a considerable presumption that the Psalm was in our Lord's mind when He called Himself the Son of Man.

Now this splendid Psalm was no doubt in the first instance written of Man, in the sense of Humanity: 'What is Man that Thou art mindful of him, or the Son of Man that Thou so regardest him?' So that, in taking it to Himself, it seems to me that our Lord must have regarded Himself as in some manner repre- 
senting Humanity. The idea of 'representing' may seem to be too modern; and that of embodying an ideal humanity may seem to be more modern still. I do not know exactly what expression to use so as to avoid this. An ancient might have had some diffculty in expressing the abstract idea; it seems to me that the word 'represent' is just what the ancients wanted. But, however that may be, I feel sure that there was a deep reality corresponding to it in the consciousness of our Lord. The great passage to which I would appeal in proof is St. Matt. xxv. $31-46 .{ }^{1}$ Here, as in the Book of Enoch, the Son of Man is seated on His throne as Judge; and He accepts some, and rejects others, of those who are brought before Him, on the express ground that actions done, or not done, to their fellow-men, had been done, or not done, to $\mathrm{Him}$.

This is the most conspicuous, but it is not by any means the only passage in which the representative or inclusive idea is brought out in the Gospels. I would refer to the same head such sayings as, 'Every one who shall confess Me before men, him will I also confess before My Father which is in Heaven; and he that receiveth you receiveth $\mathrm{Me}$, and he that receiveth $\mathrm{Me}$ receiveth $\mathrm{Him}$ that sent $\mathrm{Me}^{\prime}$ (Matt. x. 32, 40), and the like.

I believe that this whole group of passages is of

1 I am aware that doubt is thrown on this passage by some critics. But the doubt is most wanton. Where is the second brain that could have invented anything so original and so sublime as vv. $35^{-40,42-5}$ ? 


\section{The Deity of Christ in the Gospels}

great importance. On the one hand it seems to arise very simply and naturally out of the use of the title Son of Man. It is but a kind of revival of the collective or corporate idea contained in that title from the first, though partially dormant in some of its applications. The easy contraction and expansion of the idea was, as I have said, just what would be natural and characteristic to a Jewish mind. And, on the other hand, there are few things in the Synoptic Gospels which I think also go so far to explain the Christology of the Early Church. What we have in the Gospels is not formulated doctrine; but it does express those living traits, those vital root-relations, of which the formulated doctrine was intended to take account.

These are the kind of expressions that we find in the Gospels : 'that ye may know that the Son of Man hath power on earth to forgive sins'; 'He spake as one having authority, and not as the scribes'; 'behold, a greater than Solomon, a greater than Jonah, is here!' It is in such subdued, but intensely human ways, that the Synoptic Gospels express what we call the Deity of Christ. But when we take all these expressions together, we see how they lead up to the conclusion that He was really more than man.

Going back for a moment to Ps. viii, I would suggest that it may be with this Psalm that we should associate all those hints of lowliness, humiliation, and suffering that form the other side of the portrait of the Son of Man. The Psalm really teaches Pascal's doctrine at once of the littleness and of the 
greatness of man. That is the wonder of it, that a creature to all appearance so poor and feeble should have such an exalted destiny. It seems to me that our Lord must have dwelt much on this, as well as on the other side of the picture, and that He looked at it in the light of His own experiences. At a later date, when the Passion came clearly into view, a new set of scriptures was brought to remembrance-all those which helped to portray the suffering Servant whether in psalm or in prophecy. So no element in the complex nature and fortunes of Man was left out. We might say that on these lines the Son of Man fathomed the mystery of His own incarnation.

When we pass over to the title Son of God, there are perhaps two points that may be brought out without going over again ground that is already too well trodden. We naturally take together not only the instances in which the title Son in a unique sense appears to have express Divine sanction (as in the narratives of the Baptism and the Transfiguration), but also the other places in which there is mention of 'the Father' or 'My Father' and 'the Son'. The latter class of passages is of course to be found far more frequently in the Fourth Gospel than in the others. 'The Father' and 'My Father' are fairly frequent in St. Matthew and St. Luke, testifying apparently to the usage of the second main document that we now call $Q$. In St. Mark there are only four examples of the use of $\pi \alpha \tau \dot{\eta} \rho$ of divine Fatherhood. But it is worth while to notice that two of these places 
are what may be called strong examples of the usage of which we are speaking. One is eschatological, where the Son of Man is described as coming 'in the glory of His Father with the holy angels' (Mark viii. 38 ). The other is the famous passage in which it is said that the hour of the Messiali's coming 'knoweth no one, not even the angels in heaven, neither the Son, but the Father' (Mark xii. 32). This is one of Schmiedel's 'foundation-pillars' of the Gospel narrative which, because they happen to contain negatives, he thinks may be accepted without any suspicion of their genuineness. In this I think we may agree with him, though I should be very far from agreeing that, because we attach special weight to these passages as being exceptions to the main tenor of the traclition, therefore we can afford to neglect that main body of tradition which alone gives them force as exceptions. It is, however, of real importance, in estimating the testimony to the two correlative forms 'the Father' and 'the Son', that one of the leading passages in St. Mark should bear this stamp.

Another important branch of the evidence for this usage is supplied by the Pauline Epistles. It is indeed a notable fact that the phrase 'God the Father' should occur almost in the opening words of the oldest extant Epistle, I Thessalonians. It is well known that the phrase is especially common in these opening salutations. We cannot think that it is a new coinage of St. Paul's. It comes to his pen quite naturally, and not as though it needed any explanation. I think we may safely set it down as part of the general vocabulary of K 2 
Christians. Its occurrence in the Logian document (Q) is proof that it was familiar in circles far removed from Pauline influence.

There is a further point in this connexion that I think also deserves some emphasis. Those who think that our Lord was deified by the Early Church, as a rule throw the onus of this deification upon St. Paul. We have just seen that one of the phrases by which it is conveyed is not at all likely to have been his invention. But another set of considerations tends to the same conclusion.

St. Paul has a view of his own as to the outstanding moment in the Sonship of Christ. He expresses this in set terms when he speaks of Christ as 'declared', or 'determined, to be the Son of God with power by the resurrection of the dead' (Rom. i. 4). The Resurrection (or, more strictly, the Ascension) is equally regarded as a turning-point in Phil. ii. 9-I I.

We may call this the specially Pauline view; and the same kind of stress is laid upon the Resurrection in Acts ii. 36: 'Let all the house of Israel know assuredly, that God hath made $\mathrm{Him}$ both Lord and Christ, this Jesus whom ye crucified.'

This is not exactly the view of the Gospels, and in particular of the fundamental narrative-Gospel St. Mark. Here the divine Sonship of Christ is dated at least from the Baptism. I say 'at least', because there is some degree of ambiguity as to the exact amount of significance to be attached to the Baptism. We can see that both the Baptism and the Resurrection were conspicuous landmarks in the life of Christ. But pre- 


\section{$V$. The Deity of Christ in the Gospels}

cisely how much is implied in either event is left unexplained. The Gospels of St. Matthew and St. Luke carry back the divine Sonship behind the Baptism to the Birth. St. Luke makes the youthful Jesus at the age of twelve already speak of God as 'My Father' (Luke ii. 49). The prologue to the Fourth Gospel of course goes further back still. Here, then, we have a succession of steps ; but we can only speculate as to the degree of significance of the later steps in relation to each other and to the earlier. There is no explicit statement on the point. But the marked variety of view is, I think, sufficient proof that we cannot really refer the deification of Christ to St. Paul. There is, I believe, not a single reference in the whole of his writings to our Lord's Baptism, as a landmark or turning-point in His career. The idea of Sonship in the Gospels-both the Synoptics and the Fourth Gospel-is really developed on other lines than his. St. Paul stands apart; and although the author of the Third Gospel and the Acts shows acquaintance with the same point of view, the probability is that even that point of view was really older than both St. Luke and St. Paul, and in each case was derived and not original. The active mind of St. Paul no doubt worked out, enriched, and applied in manifold detail the ideas that came to him. But the workshop in which those ideas, in their simpler form, were forged was the apostolic Community in its early sojourn at Jerusalem.

We have spoken of the two main titles, Son of Man and Son of God: the latter, used sparingly and for the 
most part indirectly by our Lord Himself; the former, His own special choice and the mould in which $\mathrm{He}$ cast the deepest utterances of His self-consciousness and of $\mathrm{His}$ experience. There remains a third title, Christ or Messiah, of which Son of Man is really a variant. It is a variant in two directions; one, strictly çschatological, and in the current tradition of the time tending to be narrowed down to the function of the Messiah as Judge; the other, made the receptacle for our Lord's own conception of $\mathrm{His}$ character and mission. The name Messiah was a rather wider embodiment of the Jewish expectation with a stronger emphasis on the function of the King as contrasted with that of the Judge.

For a classical example of the idea of the Messiah as it was inherited by our Lord from the century that preceded His coming, we cannot do better than go to the seventeenth of the Psalms of Solomon. I give the extract in the translation of Drs. Ryle and James :-

Behold, O Lord, and raise up unto them their king, the son of David, in the time which thou, $\mathrm{O}$ God, knowest, that he may reign over Israel thy servant ;

And gird him with strength that he may break in pieces them that rule unjustly.

Purge Jerusalem from the heathen that trample her down to destroy her with wisdom and with righteousness.

He shall thrust out the sinners from the inheritance, utterly destroy the proud spirit of the sinners, and as potter's vessels with a rod of iron shall he break in pieces all their substances. 
He shall destroy the ungodly nations with the sword of his mouth, so that at his rebuke the nations may flee before hin, and he shall convict the sinners in the thoughts of their hearts.

And he shall gather together a holy people, whom he shall lead in righteousness; and shall judge the tribes of the people that hath been sanctioned by the Lord his God.

And he shall not suffer iniquity to lodge in their midst; and none that knoweth wickedness shall dwell with them.

For he shall take knowledge of them, that they be all the sons of their God, and shall divide them upon the earth according to their tribes.

And the sojourner and the stranger shall dwell with them no more.

He shall judge the nations and the peoples with the wisdom of his righteousness.

And he shall possess the nations of the heathen to serve him beneath his yoke; and he shall glorify the Lord in a place to be seen of the whole earth;

And he shall purge Jerusalem and make it holy, even as it was in the days of old.

So that the nations may come from the ends of the earth to see his glory, bringing as gifts her sons that had fainted,

And may see the glory of the Lord, wherewith God hath glorified her.

And a righteous king and taught of God is he that reigneth over them;

And there shall be no iniquity in his days in their midst, for all shall be holy and their king is the Lord Messiah (Pss. Sol. xvii. 23-36).

This is not the whole of the passage, but it will be enough for my purpose. It will show, unless I have misunderstood him, how wrong Schweitzer is in deny- 
ing the political element in the Jewish conception. The conception is all political, based upon the circumstances of the moment. It expresses the dissatisfaction of the Pharisees with what they considered the usurping régime of the Hasmonaean princes, as well as their deep-seated antipathy to foreign rulers. The ideal to which the writer clings is one in which there shall not be an alien left in the midst of the holy people (ver. 3I).

All this intensely national and particularist side of the expectation our Lord certainly discarded. But $\mathrm{He}$ did not discard the eschatological side. We must not forget that the kingdom just described, although on earth, is yet essentially eschatological ; and, because eschatological, it is also essentially transcendental and supernatural. It is brought about by the intervention of God Himself; and that intervention takes the form of a series of catastrophes, which must come to pass before the reign of righteousness can begin.

There is no explaining away this deep-rooted element in the consciousness of our Lord. On this rock the persistent efforts to minimize the significance of His Person must assuredly be shipwrecked. Such chance of success as they have ever seemed to have has arisen from the fact that the period of His earthly ministry was really a period (so to speak) of occultation, in which the full display of His divine power was deliberately restrained and held back. But behind all our Lord's teaching we can see the conviction that this restraint would be only for a time, that $\mathrm{His}$ manifestation in $\mathrm{His}$ true character was only delayed, 
and that He Himself would be the chief agrent in making real and effectual the reign of God upon earth.

The appellation 'Son of David' is just a sub-head of the doctrine of the Messiah. In liberal quarters it is commonly held that the question raised by our Lord in St. Mark xii. 35-7 and parallels was intended as a disclaimer for Himself of the title. But it seems to me that Schweitzer's reply (p. 392) to this view is complete. The question propounded was no mere abstract conundrum: it was a real problem, which had exercised the mind of our Lord Himself, as it had for Him a very personal bearing. He really had the answer to the question, though $\mathrm{He}$ did not give it. As descendant of David, $\mathrm{He}$ was to that extent subordinate to him; but as Son of Man enthroned at the right hand of God, $\mathrm{He}$ was his Lord.

So far I have been drawing only upon Synoptic Gospels. When we turn to the Fourth Gospel, the first thing that we have to do is to distinguish between the teaching of the main body of the Gospel which is put into the mouth of Christ, and the teaching which belongs to the evangelist in his own person.

Copious as it is, the language that falls under the first head is all the development of a single idea. It all grows out of the filial rilation; it is a working-out of the implications of the title Son of God. The idea, as we have seen, rests upon evidence that is far older than the Fourth Gospel. It would not be wrong to call it the first proposition of Christian theology, 
the first product of reflection upon the Life of Christ that has come down to us. The most detailed analysis of the idea is no doubt to be found in the Fourth Gospel; but that Gospel really adds nothing fundamentally new. When once we assume that our Lord Jesus Christ thought of Himself as Son, thought of Himself as the Son, thought of God as in a peculiar sense His Father, or the Father, all the essential data are before us.

The Fourth Gospel enlarges upon this theme more than the others. It does so for a special purpose, because it is the very centre and pivot of Christianity. The writer of the Fourth Gospel wanted to make Christians-convinced Christians, and therefore it is that he reiterates the truth which he thought best designed to make them.

He no longer, or but rarely-as we have seenthrows this into an eschatological form. Not that he denied, or dropped, the expectation that the Lord would really return to His people-the First Epistle says expressly, 'Little children, it is the last hour' (ii. I 8)-but only that the author wrote at a time when long postponement had caused this idea to lie comparatively dormant, and had brought other ideas to the front in its stead.

The writer has one special idea of his own, what we are in the habit of calling the doctrine of the Logos. In a Greek city, on the shores of the Aegean, one of the great centres of Hellenic culture in those days, it was natural that he should think of this term as specially adapted to commend what he desired to 
teach to his hearers and readers. I do not myself think that he had any great acquaintance with Greek philosophy, even in its Alexandrian or semi-Jewish form; what acquaintance with it he had I suspect was derived more from intercourse with men than from books. Just as St. Paul disputed with Stoics and Epicureans at Athens, so also St. John may well have held prolonged debates with disciples of Philo: some of these may have been converted, and he may have lived in close intercourse with them. In this way he may have got the term Logos; but I believe that he read into it a different content derived from other sources. He saw that it expressed more comprehensively and more significantly than any other word that aspect of Christ's Incarnation that he most desired to express; and he welcomed the fact that it was a rich and suggestive word with which the philosophy of the time was familiar. But the writer whom we, as I believe rightly, call St. John, was not in bondage to a word. He used this, as he used other language, and as other Apostles before him had used it, to convey that he personally had found the Way, the Truth, and the Life, and he desired to make his own experience available for all mankind.

That is really the meaning of all Christian theology. The facts come first; the formulae, or groups of formulae, which express and partially explain the facts by correlating them with the whole body of belief, come afterwards.

If we go back to the ultimate facts of the Life of Christ, how simple they are, especially in their Synoptic 
presentation! 'Ye have heard that it was said to them of old time... but I say unto you'; 'behold, a greater than Solomon is here'; 'if any man come to $\mathrm{Me}$, and hate not his father and mother ... yea and his own life also, he cannot be My disciple'; 'ye have the poor always with you, but Me ye have not always'; 'Come unto $\mathrm{Me}$, all ye that labour and are heavy laden, and I will give you rest.' If this is selfassertion-and it is really self-assertion-the phrases that I have just quoted are such as no earthly potentate and no earthly saint could use as Christ used them -if they imply self-assertion, how modest it is, how gentle, and yet how firm! 'Modest' is perhaps hardly a word that ought to be used in this connexion. 'Take My yoke upon you, and learn of Me, for I am meek and lowly in heart,' are the words of Christ Himself. They do not describe the whole of His human character. That is another point that has been brought out in recent years-what we might call the masculine side in the character of our Lord. The other, beautiful as it is, and true as it also is most emphatically, is yet almost feminine, and so one-sided. And the one-sided stress that has been laid upon it has impressed a certain air of softness, sometimes approaching effeminacy, on second-rate religious art. There undoubtedly is another side than this. Our Lord, it is manifest enough, could be stern and severe. He could set His face like a flint in carrying out a high resolve. He could expel buyers and sellers from the temple; He could lash scribes and Pharisees with scathing words. He could go to $\mathrm{His}$ death without 
a murmur, with outward calm, though there was deep trouble-even, at one moment, agony-within. It is just this that is so wonderful in our Lord-the perfect balance of what is with us masculine and feminine, so that the scale inclines neither way. It is no mere compromise, but a marvellous fusion of opposed types, each in its perfection.

But what I want to invite you to look at is the nature of those little indications-for they are really little indications, strangely delicate and unobtrusivescattered over the Gospels, that in spite of the humble form of His coming $\mathrm{He}$ was yet essentially more than man. Let me ask you to observe how it is all in keeping. It is in keeping with what I have already called the period of 'occultation'. Everything about the Manhood of our Lord is (so to speak) in this subdued key.

But this is only for a time. It expresses the surface consciousness, not the deeper consciousness; the deeper consciousness after all is expressed by St. John's 'I and My Father are one'. It is the unclouded openness of the mind of the Son to the mind of the Father that was the essence of His being. It is not only openness to influence, but a profound unshakable inner sense of harmony, and indeed unity, of will.

This is the fundamental fact that lies behind all our theologizings. They are but the successive efforts to put into words, coloured perhaps by the different ages through which the Church has passed, what St. Thomas meant by his exclamation, 'My Lord and my God.' 
Perhaps, in these modern days, it is well for us to go back and remind ourselves of these fundamental facts, so human in their divinity and so divine in their humanity. It is they which really touch not only our heads but our hearts and souls. 


\section{EPILOGUE}

VI. TIE MOST RECENT LITERATURE

VII. TIIE MOST RECENT LITERATURE (continued) 



\section{VI}

TIIE MOST RECENT LITERATURE

IN the course of lectures that I gave two terms ago I was very conscious of not covering the whole ground. The title by which the lectures were announced ('The Reconstruction of the Life of Christ') was tentative and provisional, and it might well seem to promise more than it performed. I was really following out a single clue-the one that seemed perhaps the most important at the time-and I knew that I was some way from embracing the whole process of reconstruction.

It is indeed very hard to be thoroughly abreast with inquiry on the wide subject of which I am speaking. On some parts of it my own reading was rather in arrears when the lectures were written, and I should like to try to make good one or two omissions due to that cause.

But, apart from that, the mere preparation and delivery of a course of lectures takes some time. It is now nine months since I began to write the lectures to which I refer. And it happens that just those nine months have been even more than usually eventful. Not only has there been in the meantime an accumulation of RECON. 
literature, some of it of a high order, but the position as a whole has undergone a not inconsiderable amount of change. I should be glad, if I can, to give some account of this.

And then, lastly, there is the progress-such as it is -in one's own mind. I confess that it would be a satisfaction to me to return once more to the subject of my lectures, and to make another effort to formulate or express at once with justice and with accuracy the sum of the impression which the survey that I have been attempting leaves upon me. It is in such small ways, by the incessant effort to restate things to one'sself, to correct what is one-sided and to attain to a really balanced view, that not only the individual mind but the public nind makes its advances. What I may contribute will be of course only a drop in the ocean; but I do not know that one can have a higher ambition than to make one's own contribution, however small, as just and as true as one can.

These three things - the wish to repair one or two omissions, the wish to take account of what has appeared in the last few months, and, perhaps most of all, the wish in part with the help of this recent literature to improve the summing up that I laid before you-are my reasons for taking up the thread of my discourse again.

I began my previous course with a very brief and summary sketch of what had been done in this country, not so much upon the Life of Christ as in preparation for the study of the Life of Christ. I pointed out how, in contrast to much that had been done or attempted 
upon the Continent, the work done here had very largely had this preliminary character. I noted its caution and deliberate self-restraint. I did not disguise the fact that to the outside world this self-restraint might well appear to be a lack of enterprise. And, looking back now, I can see some ill results from that apparent lack of enterprise. Wholesome as I am sure that it has been for us who are engaged upon the work, I can understand that it may have seemed to come short of the legitimate demands that might have been made upon us by the nation. Ideally speaking, the nation and its theologians ought to move altogether. The theologians ought to carry the nation with them in each step of their own progress; they ought to warn the nation what is coming, and they ought to inform the nation as soon as it has come. It is perhaps true that we theologians have been rather backward in doing this, and that, as a consequence, some things have come to the nation in a more startling form and with a greater degree of seeming novelty than they really possessed. The fact has been that we theologians, at least most of us, have had some leeway to make up of our own; we have had to learn for ourselves before we could teach; and we did not think it right to produce our lesson by instalments, before we could see it as a whole. At least we have really been trying so to produce it; but the nation should understand that to do this is a difficult and a delicate and a responsible process, and that (human nature being what it is) it should not be surprised if there have been shortcomings in the performance. 
However this may be, what I said about the course of English theology in the last twenty years may have done something to explain that it has not really been idle, but has accomplished more than might be supposed, though the work done has been of a kind less available for general purposes than might perhaps have been wished.

That was, broadly, the description that I gave of the last twenty years among the English-speaking peoples. But in preparing the lectures for the pressand they are now in print-I introduced a few expressions here and there to bring out the opinion which I was inclined to form that the period I had been describing had practically come to an end. I believe that the year 1906 may be said to mark the turning down of one page in the history of English theology and the opening of another. I was led to this opinion by one or two phenomena, not on a large scale, which I took to be signs of the times and to portend more of a change than they actually inaugurated.

I had spoken of the general solidarity of our English Universities, i. e., in particular, of the theology taught. in them. The wonder to me really was that that solidarity should have been maintained so long. It was not to be expected that it could last much longer. The indications of approaching change came, as it happened, less from England than from Scotland. The most typical book in this respect that I have read for some time is that of Mr. Ernest F. Scott on the Purpose and Theology of the Fourth Gospel (Edinburgh, 
I 906). Mr. Scott is a Balliol as well as a Glasgow man, and we can trace something of Oxford as well as of Scotland in his book; but the Oxford element that we trace in it is not exactly theological. The nearest parallel that I am aware of was Dr. James Moffatt's Historical New Testament, published a few years ago. $\mathrm{Mr}$. Scott is an admirable writer, and shows especial skill in the handling of ideas; he has also a seriousness and strength of conviction that are decidedly attractive. But the most marked thing about him to my mind is his stancl-point, which is identical with that of the more sober theological liberalism in Germany. The Germanism is thorough-going-so thorough-going that it is not argued but is simply taken for yranted. Something similar might be said of Dr. Moffatt, though with slight qualification. Later still, we have had Dr. Salmon's posthumous book, The Human Elcmint in the Gospels (London, 1907), which is in its way even more significant, because the change which it marks is not due to any external influence, but to the internal development of the writer's own mind. In the English Universities also there are signs of a less conservative and more adventurous spirit: and I do not doubt that we shall have more in the future.

This forecast upon which I ventured had nothing to do with the 'New Theology'. I am not sure whether at the time when it was made the public discussions which go by that name had begun. However, now they are upon us, and upon us in a flood; and, even though the waters may subside, the face of the landscape will never quite be what it was again. The cir- 
cumstances were just of the kind that in this country makes more impression upon the mass of the public in a few weeks than the quiet work of retired students in as many months and even years. This is just the unfortunate part of it. Publicity with us means so much publicity. It means rallying cries, and the forming of party organizations, and propaganda-very often before it is at all clear what it is sought to propagate. A movement is forced on, and clamour arises, and the issues are soon confused in the strife of tongues.

I am not saying who is to blame for this. Very often a lurge share of the blame attaches not so much to individuals as to public opinion and its organs, which are too mercurial in their way, and are apt to aggravate local disturbances of the atmosphere which they begin simply by recording.

Something of this kind I believe has happened in the present instance. It would have been a far more wholesome state of things if the novement which is rapidly becoming full-fledged as a movement had remained some time longer at the stage of quiet individual study. The misfortune is that it is thrust before the public long before it has been really thought out. And the point on which it seems to me to need the greatest amount of further thinking is in regard to the relation between the old and the new. There is much in the principle that lies behind the movement that may be right enough and true enough in its proper place and degree. But then it is stated with exaggeration, and with a lack of proportion and 
of the necessary qualifications which jars against the Christian conscience.

The strange thing is that the leaders of the movement hardly seem to be aware what they are doing. For instance, in the paper which opens the April number of the Hibbert Fournal, which I suppose may be taken as a programme of the movement as it stands at this moment, there is much that is excellent and with which one can entirely sympathize. Thus we are told that 'the impression that the New Theology involves a breach with historic Christianity is utterly untrue'. Again: 'The adherent of the New Theology tries to get beneath every venerable statement of Christian belief, and bring to light the essential truth implied in it.' No one could be better employed, if he would but take his task seriously and patiently. Yet again: 'its emphasis is positive, not negative; it is a return to simplicity of statement and to the preaching of an ethical Gospel.' By all means let us have 'simplicity of statement'; it is a true note of the effort after reconstruction in which we are almost all in different degrees engaged. By all means, too, let us have 'the preaching of an ethical Gospel'. That also is a sign of the times, and a good sign-provided that it does not attempt to drive out everything else. But then, in the very next breath we are told that 'like Humanism, it discards every theologoumenon which has not a practical ethical value'. The mischief lies in the sweeping negative, which may well set the loyal Christian on his guard, as he knows how much that is precious to him may easily be included. And in the same spirit we 
read just before: 'In applying this method they must inevitably sweep away many of the misleading and inadequate statements of belief which in the popular mind are supposed to be synonymous with Christian truth.' There, once more, we know what to expect; and $I$ am afraid that our expectations are realized to a greater extent than they need be.

The pity of it is that, if I understand the New Theology rightly, its advocates might have all that they want-or at least all that they ought to want, which is not perhaps quite the same thing-without any real disturbance of the greater landmarks of Christianity. There is a smaller movement at work, which, just because it hardly amounts to a movement but is rather a diffused intellectual influence, I must needs think happier in its conditions, that seems to me to be pursuing similar ends in an altogether more hopeful way and well within the bounds of historical Christianity. I refer to the influence exercised by the writings of Dr. Moberly in this country and Dr. Du Bose in America. And along with these may be named the works of Mr. Illingworth and Dr. Inge. I would earnestly commend the study of these writings to all who are drawn towards the New Theology. As some account will be given of a portion of this literature at the end of the present volume, I need not say more about it now.

It is true that there is a quest after what may not wrongly be called a New Theology on foot over a great part of Christendom, conducted by different methods and by men of different temperaments and 
different tongues. And I am inclined to think that this movement is not badly described when it is said that 'The New Theology is an untrammelled return to the Christian sources in the light of modern thought. Its starting-point is a re-emphasis of the Christian belief in the Divine immanence in the universe and in mankind.' " The first of these sentences is more widely true than the second. If we give some latitude to the word ' untrammelled', I should say that to speak of the New Theology as ' an untrammelled return to the Christian sources -certainly to speak of it as 'a return' to the sources- ' in the light of modern thought' would describe all forms of the effort everywhere. And the second sentence, which speaks of 'a reemplasis of the Christian belief in the Divine immanence in the universe and in mankind', would also describe a considerable section of it, especially in this country and in America; and we might add perhaps the movement associated with Auguste Sabatier in France. I doubt if there would be so much stress on 'the Divine immanence' in Germany. In Germany the main impulse came from Ritschl, and we have to remember that Ritschl-and the same thing would be true of his followers--was strongly opposed to everything of the nature of Mysticism. His theology might well be described as having for its object 'the preaching of an ethical gospel'; but it would not do this in terms of Divine immanence. I do not think that that doctrine is prominent in the teaching of the school that holds the field there just at present.

1 The New Theology, p. 4. 
While it is true that the effort after theological restatement is widespread, including as I believe many who are anxious to maintain a full continuity with the Christian faith in its historical expression, I should like to put in a word of warning against the idea that this effort has yet attained to anything like a completely satisfactory formulation. The task is one that it must be quite obvious cannot be carried out in a day. It is really an immense task, and one that may well strain all our mental energies for years to come. And nothing but harm will come from raising our paeans too soon. Let us maintain the modest attitude of seekers, and in particular not be in a hurry to sally forth into the streets to teach until we have learnt our own lesson, and made sure that we have learnt it well.

I must make a rather abrupt transition to an altogether different field from that with which I have so far been dealing. One of the chief events of the last nine months has been the appearance during their course of two parts of Harnack's new publication which he calls Beiträge zur Einleitung in das N.T. ("Contributions to N. T. Introduction'). Any one else might be proud to have produced one such volume in the time, for they both bristle with critically sifted detail, but Harnack can only be compared with himself; we can put no limits to his power of production.

Quite recently two of Germany's foremost scholars have come to grapple at close quarters with the problems of the Gospels, Wellhausen and Harnack. Wellhausen really came first, and he ought to have 
filled a larger place in my earlier lectures; but $\mathrm{I}$ am glad to be able to speak of him along with one as great as himself.

All study of the Gospels must really be founded upon close literary analysis. But for some time past Germany had not done anything very special in this way-not more than has been done in this country. A useful survey of the Synoptic Question by P. Wernle had been published in 1899 . Juilicher had treated the subject with conscientious thoroughness in the successive editions of his Introduction. Bernhard and Johannes Weiss, father and son, had continued their labours upon it; and some lesser excursions had been made into it by von Soden, Soltau, Zimmermann and others. But it was distinctly an event that two such scholars as those I have named should enter the arena.

Wellhausen began with a concise commentary on St. Mark in 1903 ; a similar treatment of St. Matthew and St. Luke (omitting the first two chapters of each Gospel) followed in 1904; and the series was completed by an Introduction to the First Three Gospels in 1905 . The design and form of the series showed characteristic independence. No attempt was made to produce a complete commentary; it was but rarely that reference was made so other views than the author's own; he just annotated the points that struck him in the fewest possible words, and left the rest alone. The Introduction, if rather more systematic, was equally concise. But it was all a direct first-hand study of the text; and this, coming from a scholar of so much experience and so steeped in knowledge of the 
history, languages and modes of thought of the East, could not but be of importance.

Wellhausen's most eminent speciality had to do with the language; and it is interesting to know that for both the leading documents that lie behind our present Gospels, the Mark-gospel and the collection of discourses or $Q$, he believes in an Aramaic original. It may be said generally that German writers, whether or not they contend for Aramaic originals, are coming to see that the great mass of the Gospel tradition is really redolent of the soil of Palestine, and that this is a great guarantee of its substantial accuracy. It is also interesting and also important that Wellhausen and Harnack, without any connexion with each other, as well as all the other writers I have mentioned, agrce in postulating these two documents as at the base of the Synoptic tradition. So far as consent can prove anything-and it is to be remembered that in this case the consent is of scholars of the highest competence who have all worked directly and closely upon the factswe may really, I begin to think, take the second document as well as the first as practically assured. Our English workers would, I believe, with almost the same unanimity agree in this conclusion. Dr. Salmon comes nearer than most of us to the special form of the theory adopted by Bernhard Weiss, but he also has the two documents. It should be said, however, that Wellhausen does not take the further step (that e.g. Dr. Salmon takes) of identifying the two fundamental documents with the works by Matthew the Apostle and Mark the companion of St. Peter spoken of by 
Papias and his informant John the Presbyter. After his manner, he abstains from pronouncing upon this point either way. Harnack regards the identification as on the whole probable, but he will not say more.

Wellhausen thinks that there is some later matter as well as earlier in the second Gospel; but he will not specify this too precisely. In the main he may be saicl to constitute himself the champion of the Mark-gospel. As between this and the other document that we are now calling $Q$, he nearly always takes its side, in a way that almost amounts to partiality. Harnack redresses the balance by what is at least a steady defence of $Q$, to which he has devoted a special study. On the vexed question, on which there is so much division of opinion amongst scholars, as to the precedence in authority between St. Matthew and St. Luke, Wellhausen is one of those who in the main would give his suffrage for St. Matthew.

In the third part of his Introduction, which deals with the Gospels as history, Wellhausen makes many remarks in his terse and pointed style that well cleserve attention. And yet his habit of mind is distinctly sceptical-I do not use the word in an invidious sense; Dr. Du Bose has lately told us, and I agree with him, that scepticism too has its place in the ways of Providence. By scepticism I mean the tendency to question one's data; and I think that Wellhausen is unduly disposed to question his. He is also apt to set down a good deal more than I should think right to the 'early Christian community'. And he sometimes leaves a certain ambiguity as to whether the alternative 
that he prefers represents an early form of legend or actual historical fact.

Wellhausen draws a useful distinction-which we have of course all drawn in a way, though we have not perhaps always applied it quite so clearly and directly as we should have done to the Gospel history-between the Jewish and the Christian Messiah. It was as the Jewish Messiah that our Lord was confessed by St. Peter. There is no reason to doubt this confession or to suppose that it has been placed too early. It was as the Jewish Messiah that Jesus was condemned, and that Pilate wrote 'the King of the Jews'; and it was in the same character that $\mathrm{He}$ received the mock homage of the soldiers. The jubilant crowd which accompanied the entry into Jerusalem gave their welcome to one whom they believed to be on the point of restoring the kingdom of David. What was the feeling of Jesus Himself all this time, Wellhausen thinks is not so clear. In any case $\mathrm{He}$ did not go about, like the false Christs, saying 'I am he'. Jesus accepted homage when it was offered to $\mathrm{Him}$; and $\mathrm{He}$ skilfully baffled attempts to extract from $\mathrm{Him}$ a definite declaration. The political side of the patriotic movement $\mathrm{He}$ steadily repudiated. The yoke that $\mathrm{He}$ felt was not that of the foreign domination but of the hierarchy and the scribes, with their deadening traditions. He desired to bring about a new birth of the nation-and that not merely by the rescuing of a few individuals, because if that alone had been His object He need not have gone up to Jerusalem.

All this Wellhausen rightly sees; and yet, when he 
speaks of the Christian Messiah, he means not so much Jesus' own conception of His Messiahship as that transfigured conception which the nascent Church threw back upon His lifetime after His death. Wellhausen does not now dispute the use of the title "Son of Man'. He takes it simply in the sense of 'Man', and makes it point back to 'the Man'-i.e. the human figure as opposed to the four beasts-in the vision of Dan. vii. I3. On this point scholars are now practically agreed. As I understand Wellhausen, he thinks that the use of the name, along with the expectation of the (Second) Coming, belongs to the very beginnings of the Christian Church. According to Wellhausen, the first step is belief in the coming of the Kingdom; then in the coming of the personal Son of Man; and lastly, the identification with our Lord. Not even so much, it seems to me, can be interposed between the Crucifixion and I Thessalonians. I have really no doubt that all three steps were run through in the lifetime of our Lord, though they were of course confirmed by His Death and Resurrection. ${ }^{2}$

Wellhausen lay's great stress upon the activity of our Lord as a teacher. In direct antithesis to Schweitzer, he describes the Galilaean ministry as consisting not in announcement but in teaching (Einl. p. 106). The main subject of the teaching is 'the ways of God' (p. 94). The idea of the kingdom of God (more strictly, 'rule or reign' of God) is taken over from the later Judaism, where it was in contrast not so much to

1 The most important places for Wellhausen's view are $M c$. pp. 66-9, Einl. pp. 96-8. 
the rule or reign of Satan as to the domination of the heathen oppressors, a state of things to which the Jewish people had become accustomed from the Captivity onwards (p. 100). It is not quite clear how far the idea of a present kingdom is ascribed to St. Matthew, and how far to our Lord Himself. It is treated as characteristic of the First Gospel, and Wellhausen himself seems to lean towards this conception, though he also speaks of it as a step towards the comparative suppression of eschatology in the Fourth Gospel. It is noticeable that in this context (p. 105) he differs from many of his countrymen by adopting the rendering, 'the kingdom of God is within you' rather than 'among you' in Luke xvii. $2 \mathrm{I}$.

It seems to me, if I am not mistaken, that Wellhausen's scepticism, especially as to the predictions of the Passion and (Second) Coming, involves him in some inconsistency. At least, he speaks with rather bitter irony of those 'advanced theologians' who take the view that predictions of the Parusia were suppressed because as a matter of fact they were not fulfilled (p. 98). And yet he himself is inclined to minimize the eschatological element, especially in our Lord Himself. He says expressly, 'The eschatological hope acquired its intensity first through the oldest Christians, who attached it to the Person of Jesus' (p. 107). It is also maintained that the attitude and behaviour (Lebenswandel) of Christ 'had not such an eschatological cast as that of His disciples who renounced the world in order to prepare themselves for His Advent'. The idea is also rejected with some show of indignation 
that there was anything in His moral teaching at all of the nature of a merely provisional asceticism which was only to be enclured for a time in expectation of the near approach of the end-which I suppose is meant for Schweitzer and his Interimsethik.

I have touched chiefly upon points that I think are most likely to help us in shaping our own conclusions. Wellhausen does, I believe, supply a wholesome corrective against any tendency to make too much of eschatology. He seems to me, as I have said, to be too sceptical as to his data to be able to construct a really satisfying picture. And he himself, I cannot help suspecting, has some inkling of this. His book ends with an impressive paragraph in which he deprecates the cry for a return 'to the historical Jesus'. The Jesus of history, he says, is wrapt in too much uncertainty, and the cry is apt to mean no more than the old Rationalism come up again. Jesus cannot be understood apart from the effect of His coming, and if $\mathrm{He}$ is separated from this, justice will not be done to Him (p. I 15). Without the Gospel and without St. Paul the Judaism that $\mathrm{He}$ retained would still have clung to $\mathrm{Him}$, though $\mathrm{He}$ had really outgrown it. The two closing sentences are striking. "If it had not been for His death, Jesu's would never have become a subject for history. The impression of His career depends upon the fact that it did not run to its conclusion, but was broken off short, when it had hardly begun.'

Of still more importance, especially for us in England, is the appearance of Harnack on the field of RECON. 
Gospel criticism. Apart from his astonishing rapidity, range, and power of production, apart from his extreme keenness of insight, brilliance of combination, and fertility of ideas, there is something about Harnack's writings that attracts us more than those of almost any of his countrymen. It is an instance of the way in which individual genius soars above national peculiarities. Harnack has not only all the German virtues in the highest degree, but he has others that are less distinctly German - a width and generosity of outlook, a freedom from pedantry, a sympathy and understanding for human weakness, that are all his own.

Of course Harnack has always been a critic; behind all his work there lie critical processes; we were well aware that even his incidental references to the Gospels were not made at random. And yet it was an event when he came to deal with the criticism of the Gospels more directly and at closer quarters than ever before. And the interest for us in England was increased by the fact that the first subject on which he was led to pronounce was one on which English scholarship almost in a body was ranged on one side, and German scholarship almost in a body on the other, and that in this debate Harnack cast his vote into our side of the scale.

It was the old question as to the so-called 'Wepassages' which occur in some five chapters of the Acts (xvi, xx, xxi, xxvii, xxviii). German scholars generally hold that these passages represent a sort of diary or notebook by a companion of St. Paul, worked up in the narrative of the Acts by a later editor. 
Englishmen, very nearly with one consent, ${ }^{1}$ hold that, whether or not there was anything of the nature of a written diary, in any case the author of it and the final editor of the whole book are the same person, and that no other than the traditional author St. Luke.

In adopting this view, Harnack based it upon three main grounds, each of them examined with the greatest thoroughness : (1) the consistent unity of style throughout the whole book; (2) the unity of ideas and other characteristics than style between these passages and the rest of the book; (3) the particular evidence that the author of the book was distinguished, as we know St. Luke was, by medical knowledge and training.

Naturally to me the argument seemed very decisive ; but it was soon challenged by a near colleague of the author. Harnack and Schürer are joint editors of that admirable fortnightly review the Theologische Literaturzeitung, and in this Harnack often gives a sketch in outline of the contents of his own books. He did so on this occasion of his book Lukas der Arzt (Leipzig, 1906) in the number for July 7 of last year; but his fellow editor thought the matter so important that he must needs append a note, three times the length of the original article, controverting its conclusions. The criticism also turned round three main points: (1) the insufficiency of the argument from style; (2) the objections from the side of the Higher

1 Among those who have dealt with the Acts directly and in detail, either as commentators or as authors of articles and monographs, the consensus includes Lightfoot, Salmon, Hobart, Ramsay, Chase, Knowling, Headlam, Bebb, Rackham, Hawkins, Moffatt. 
Criticism to the view that the book could possibly be by a companion of St. Paul and an eye-witness of some of the events recorded in it; (3) indications in the shape of abruptnesses of transition and omissions that the writer of the book was following a document which he used somewhat clumsily. Harnack replied a month later, not giving way on any of his points; and there the controversy stood for the time. There we also will leave it for the moment, but we shall soon have to come back to it again.

The main question of Harnack's monograph had to do with the Acts rather than the Third Gospel, but incidentally a good deal of light was thrown also upon the Gospel. Perhaps the most interesting point had reference to the authorship of the special matter characteristic of St. Luke and not found in either of his other two leading authorities, the Gospel of St. Mark and the non-Marcan document $Q$. Harnack suggested that this peculiar matter, of which he gave a rather depreciating account, might well have been derived from Philip the Evangelist and his four daughters, who appear to have been settled at Caesarea (Acts xxi. 8, 9), where St. Paul was detained for two years, with St. Luke as it would seem in his company. Early in the present year Harnack came back to the Gospels with another welcome monograph, Spriiche und Reden Fesu ('Sayings and Discourses of Jesus'), which is further explained as a name for the 'Second Source ' of St. Matthew and St. Luke. It was another great advantage to have so central a question dealt with by a first-rate scholar like Harnack, and it was 
discussed by him with characteristic freshness, precision, and thoroughness. I have already said that Harnack defends this second document against the criticisms of Wellhausen, and vindicates for it a high value.

I ought perhaps in passing to express my own dissent from the conclusion at which Harnack arrives about the first two chapters of St. Luke's Gospel. He regards these chapters as the composition of St. Luke hinself, based indeed upon a special tradition, but owing their form entirely to the evangelist. The argument that he uses is solely that of style. But this is just, I cannot but think, an instance of the limitations of that argument. I believe myself that the phenomena of the style can be otherwise explained. St. Luke always impresses his own signature upon his documents, and no doubt he has done so here. But when we come to look at the subject-matter of the chapters, we at once see a number of features in them which cannot possibly have originated with St. Luke. These features fall under two heads. They are (1) a number of minute allusions to Jewish law and Jewish ceremonial which are quite different from St. Luke's manner. We know, for instance, how he avoids and omits the passage about Pharisaic customs in St. Mark vii. And the other point (2) is the extraordinary extent to which these chapters hit the attitude of expectancy which existed before the public appearance of Christ. It is not only expectation, and tense expectation, but expectation that is essentially Jewish in its character. This is perhaps most marked in the Benedictus, which one might read through and hardly 
realize that it was in any sense a Christian production. The same thing is true in the main of the other Canticles; but it stands out even more conspicuously in the whole picture of Zacharias and Elisabeth, of Simeon and Anna, and in many incidental expressions, like 'walking in all the commandments and ordinances of the Lord blameless', 'this man was righteous and devout, looking for the consolation of Israel', 'she spake of him to all them that were looking for the redemption of Jerusalem' (i. 6 ; ii. 25,38 ).

I have ventured to maintain, in a paper that is being printed in America, that these two chapters - whatever the date at which they were first committed to writing -are essentially the most archaic thing in the whole New Testament, older really in substance-whatever may be the date of their actual committal to writingthan 1 and 2 Thessalonians.

The work both of Wellhausen and Harnack was work upon the foundations - ' underground work' as it has been called-and specially welcome on that account, because (as the Gospel has taught us) there is all the difference in the world between building a house upon the rock (i.e. upon solid and critically tested materials) and upon the sands of shifting theory and conjecture. But there is not less of living interest in work upon the superstructure. And for the particular task that I have been essaying, there was special importance in the appearance, at the end of last year, of a substantial pamphlet by Jülicher, which was also an attempt to survey the situation in the light of recent literature. The pamphlet was entitled Neue Linien in der Kritik 
der evangelischen Überlieferung, 'New Lines in the Criticism of the Gospel Tradition' (Giessen, 1906). Jülicher's is a highly trained and a practised hand ; and his task was in the main excellently done. He and his countrymen have carried to a high pitch of perfection the art of objectively reproducing the contents of books that they criticize. They read the books so carefully and so thoroughly, and with such a constant eye to their general drift and to the ideas which they represent, that they are able to pack into a comparatively small space a surprising amount of definite information. And so in Jülicher's pamphlet there is a great deal of admirable statement, at once full and condensed and in the main objective. I can only say 'in the main objective', because the treatment is not always equally just. There are two examples of what I cannot but think rather conspicuous injustice. Jülicher is essentially an honest writer; it is one of his country's virtues that its Universities have a high standard of intellectual honesty. But Jülicher is at the same time a party man; and the spirit of party, which he has made his own, does sometimes carry him away.

I imagine that one of the motives, perhaps the first motive, which prompted him to take up the pen, was the sharp attack delivered by Schweitzer, of whom I had much to say in my previous lectures, against the head quarters of theological Liberalism. Schweitzer is a young writer, and a writer with qualities that to one not personally concerned appeal rather for generosity of treatment. But Juilicher is evidently stung; and he sits down with the no less evident intention of de- 
molishing his opponent. He has one sentence, which it is easy to glide over, of qualified praise as of one whom he describes as 'the best-read and most undaunted critic' of the subject on which he writes; he might have added a good deal more as to his merits as a writer, and as to the sharpness with which he states the problem. But, instead of doing this, he marshals what is no doubt a rather formidable array of the ingenious but untenable individualisms for which Schweitzer has made himself responsible. I said expressly that I did not approve of these; but I did not, and I do not, think it fair to rake together these and nothing else as samples of the worth of Schweitzer's work. I believe that I conveyed a different impression; and, though I am well aware that my own presentation of the case might have been improved upon, still I must needs think that the impression that I sought to give is the truer of the two.

The other person who has had grave injustice done to him is the evangelist St. Luke. Harnack's language about him is at times-only at times-cavalier enough; especially where he is speaking of that part of the Gospel or Acts which he supposes to be based upon the authority of Philip and his daughters. The name 'prophet' used to be a title of honour; but now 'prophet' is equivalent to Ekstatiker, one who is liable to trance or ecstasy; and that is only a symbol for boundless credulity. That is one of the features in recent criticism that I strongly deprecate. It is fair to say that Jülicher remembers that St. Luke derived 
from his special source such parables as the Good Samaritan, the Prodigal Son, and the Pharisee and the Publican, and he mildly remonstrates. But when it becomes a question of St. Luke as an historian, he leaves Harnack far behind. The upshot of Harnack's argument had been to prove that St. Luke had been really an eye-witness of a certain number of the events that he related. The critic is careful to add that he does not on that account regard him as by any means wholly trustworthy. And so far I agree that, because a narrative proceeds from an eye-witness, it cannot necessarily be transplanted to our own day and accepted at once just as it stands. But Jülicher goes beyond Harnack. His comment upon Harnack's argument might be tersely summed up: 'If St. Luke was really an eye-witness, so much the worse for the eye-witness.' He goes on to point the finger of scorn at the writer who knows the name of the maid who went to the door of the house of Mary the mother of Mark on the release of St. Peter from prison (Acts xii. I3), and who also tells the story of the healings wrought by the application of handkerchiefs at Ephesus (xix. I I, I 2). In neither case have we any reason to think that St. Luke himself was present; but it seems to me-I speak only for myself-that the writer who combines two such things in the same breath gives us the measure of his own tact and delicacy of historical judgement. I fully believe myself that the mention of the name Rhoda is an excellent touch, that the whole scene is singularly lifelike, and that its credibility is not really destroyed by the introduction of the 
angel just before. That is a rather long story, upon which I cannot enter only in passing. I am prepared to contend that in the whole of chapter xii St. Luke is really following a good authority. I am not prepared to say the same thing about the exaggerated bit of hearsay as to the miracles at Ephesus. This, however, is a comparatively small charge. Jülicher goes on, in a most contemptuous tone (pp. 59,6o), to compare the picture of St. Paul as it is drawn in the Acts with that which we should infer from the Pauline Epistles-as though the object of the historian was to compose a modern biography with a psychological analysis of character and motive, and then to assign the theology of the apostle to its place in the development of Christian thought after the manner of a German professor. Of course we know very well that his real object was nothing of the kind, but rather to write a plain objective narrative of the spread of the Gospel from Jerusalem to Rome.

I am really very sorry to be brought into collision with Jülicher, which has happened to me several times before. I have a sincere respect, and even admiration, for perhaps five-sixths of his work, including particularly -I should like to say in passing-his reviews of the literature of Patristics, in which he has been at once just and generous to some of my friends here in Oxford. I repeat that the pamphlet from which I started is not only good but in many ways very good. One may go on for wide stretches in his books and find only occasion to admire. And yet every now and then one is pulled up sharp by passages like those 
of which I have been speaking, which I confess move me to indignation, so narrow are they, and so hard, so deficient in sympathy and in intelligence for the difference between one age and another.

I am afraid there is too much of this in the school to which Jülicher belongs. The writer who is freest from these faults, who indeed outsoars altogether the region in which they are apt to occur, is undoubtedly Harnack. And yet, even in Harnack, there is a thin vein which comes up occasionally of the same thing. To my regret, I find myself saying under my breath once and again

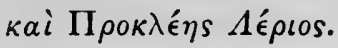

We remember Porson's paraphrase, which it would not be quite fitting to repeat.

It is interesting that Harnack's two books should be reviewed-and searchingly reviewed-by so typically British a scholar as Sir IV. M. Ramsay (in The Expositor for December, I906, and May, 1907). These articles contain many important and excellent remarks, among which I welcome especially what is said at the end of the later number on the subject of 'legend'. This is a more emphatic and trenchant way of putting the point of which I have just been speaking. It is no doubt well that we should be warned not to press the argument from style too far; but I am inclined to think that Sir William Ramsay slightly overstates his case here. The remarks that I have just been making about St. Luke i, ii will show that I would myself apply the argument with caution: but I think it is impossible to follow the work that has been done upon 
the Synoptic Problem and in the Old Testament upon the Hexateuch without feeling that it rests upon a secure and solid basis. There is one rather startling obiter dictum in the last article: viz. that 'the lost common Source of Luke and Matthew (i. e. Q) . . . was written while Christ was still living. It gives us the view which one of $\mathrm{H}$ is disciples entertained of $\mathrm{Him}$ and $\mathrm{His}$ teaching during $\mathrm{His}$ lifetime, and may be regarded as authoritative for the view of the disciples generally' (p. 424). I am afraid this is rather too optimistic. I do not doubt myself that $Q$ was written some time before $70 \mathrm{~A} . \mathrm{D}$. The more exact date will depend upon the relation in which it stands to St. Mark and to St. Paul. Under both these heads there is much to be said on both sides.

Curiously enough, Dr. Salmon uses almost the same expression as $\operatorname{Sir} W^{\top}$. M. Ramsay :-

The more I study the Gospels the more convinced I am that we have in them contemporaneous history; that is to say, that we have in them the stories told of Jesus immediately after $\mathrm{His}$ death, and which had been circulated, and, as I am disposed to believe, put in writing while $\mathrm{He}$ was yet alive.

Clearly this refers to $Q$, and not to the Mark-gospel, which Dr. Salmon follows the Christian tradition in dating about the time of the death of St. Peter at Rome.

There is another rather striking coincidence in Dr. Salmon's book. The theory that he tentatively

1 The Human Element in the Gospels, p. 274. 
propounds for the solution of the Synoptic Problem resembles closely that of Dr. Bernhard Weiss. Hitherto Dr. Weiss has not had many followers: the most important is Prof. A. Titius, of Kiel (in the volume of Essays in honour of Weiss, published ten years ago). A Seminar, which I have had the honour of holding, went into the arguments used with some care, and was not convinced by them. But now Dr. Salmon appears to have worked independently to much the same result. The fact should be allowed its due weight. The main difference between this theory and that which is more generally current, is that according to it the second document would consist almost as much of narrative as of discourse, and could not be described as non-Marcan, because St. Mark is supposed to have used it as well as St. Matthew and St. Luke. ${ }^{1}$

Another modified form of the current theory finds expression in Mr. W. C. Allen's Commentary on St. Matthew, that has recently appeared in the series of International Commentaries. This is marked at once by independence and caution, and is a good example of detailed critical work.

Only in the last few weeks a monograph has reached me by the veteran Dr. Bernhard Weiss himself on the Sources of the Gospel of St. Luke (Die Quellen des Lukasevangeliums: Stuttgart and Berlin, 1907). The views expressed in this are already pretty well known: they are most interesting where they relate to the

${ }^{1}$ A review of Dr. Salmon's book by the present writer will be found in The Guardian for July $17,1907$. 
peculiar matter of the Gospel. In regard to this I am more inclined to agree with Dr. B. Weiss than with his colleague Prof. Harnack.

My second lecture will deal, not with the literary criticism, but with the historical and doctrinal criticism of the Gospels. 


\section{VII}

THE MOST RECENT LiteratURE (continuled)

TIIE real significance of Schweitzer, about whom I had so much to say in my earlier course of lectures, is in the evidence which he affords of the dissatisfaction that is coming to be felt in Germany with the liberal school of criticism that has been dominant for so long. Another indication of the same thing may be seen in a tendency which, while it has been at work some way further back, may be said to have come forward since the year I905, as a definite movement with a definite name. The Germans describe it by one of their compound adjectives; they call it the Modern-Positive Movement in Theology. In other words, it is a more affirmative form of Liberalism, Liberalism of the Right, or conservative Liberalism. There are really two branches of this movement; and the manifesto put forward by one of them in the year 1905 was a pamphlet with the title, Modern Theology of the Ancient Faith, by Dr. Theodor Kaftan, General-superintendenta sort of Lutheran bishop - of Schleswig. Dr. Theodor Kaftan is the brother of Dr. Julius Kaftan, Professor in the University of Berlin, who is probably better known in this country as a writer. I have nowhere seen Dr. Julius Kaftan's name directly associated with the movement; but he must be in rather close sympathy 
with it ; indeed a little tract of his, Fesus und Paulus, which came out in the autumn of last year, I believe to be quite the best product of the movement that has so far appeared. The two Kaftans might be described as both belonging to the right wing of the Ritschlians; and the points on which we might be most inclined to think them defective are part of the inheritance from Ritschl. Dr. Theodor Kaftan writes with great earnestness and weight of character; I am very much with him in his general aims and objects; and yet I find myself less in agreement with him than I should have hoped in detail.

At the head of the other branch of the movement is Prof. Reinhold Seeberg, also of the University of Berlin. The movement might be said to start from a course of lectures delivered by him at Berlin, to students from all the faculties, in the winter of I90I-2, and published under the title Die Grundwahrheiten der christlichen Religion (Leipzig, I902). These lectures were apparently on the model of Harnack's famous course (E. T., What is Christianity?) delivered two years before. Seeberg's lectures do not quite come up to the level of these. They have the merits of frank, genial, and at times eloquent expression; but they are rather wanting in precision and faulty in construction; it would be wrong to expect too much from extempore addresses, given not only without MS. but even without notes, and not intended for publication. Since the lectures Seeberg has brought out an older work, recast and with a new title, Die Kirche Deutschlands im neunzehnten Fahrhundert (2nd ed., Leipzig, 
I 904), a brightly written history of German Protestantism in the last century, which contributes to the same end. Seeberg apparently has two younger lieutenants, Richard H. Grützmacher, Professor at Rostock (Modernpositive Vorträge: Leipzig, 1906), and Karl Beth, now Professor at Vienna (Dic Mloderne und die Prinzipien der Theologie: Berlin, 1907). There are also now two complete series of 'Tracts for the Times' (Biblische Zeit- und Streitfragen), which I cannot claim to have studied, but which seem likely to be useful.

A large part of the interest of the movement consists in the discussions to which it has given rise. From the liberal side there was, first, an appreciative and pleasing review of Seeberg's Kirche Dtutschlands by Max Christlieb in Protestantische Monatshefte, I 904, pp. $4 \mathrm{I} 4 \mathrm{ff}$, $470 \mathrm{ff}$; then, a criticism of Th. Kaftan by Herrmann in Zeitschrift $f$. Theol. $u$. Kirche, 1906, pp. I75-233; and, lastly, a series of articles covering the whole movement by Bousset in Theol. Rundschau, 1906, pp. 287-302, 327-4O, 37I-8I, 4I 3-24; 1907, pp. I-18).

Christlieb sums up his verdict upon Seeberg's book by laying stress on what, as we might expect, he considers its strength and its weakness. Its strength consists in the insight that it shows into 'the relativity of all scientific inquiry'; in other words, its frank recognition of the fact that Christian truth has to be restated from age to age. Its weakness, on the other hand, is on the 'positive' side, inasmuch as the course that it has to go, its 'marching route', is too much determined for it beforehand. 
I should like, if I may, to say a few words about this characterization, because it seems to me to put the whole question in a nutshell, and because in regard to it I am entirely at one with Seeberg. I should like, if I may, to say exactly what amount of truth I can recognize in the criticism. I agree that Christian doctrine has to be restated from age to age; that is, that it should be offered to each generation as it comes in the language that it can best understand. But that does not mean that the Creeds are to be rewritten for the benefit of every new generation. Neither does it mean, that the rewriting is to be entirely without relation to the Creed; nor yet that it is to be simply what we might call a bald verbatim translation of them (if that were possible) into modern language : a certain allowance has to be made under the head mutatis mutandis. But the proposition does, I think, mean that, in the effort after restatement, we should especially at first have an eye to the Creeds; and we should have a better hope of our own success if our experiment seemed to be working out on the lines of what might be called a 'correspondence of values'. I do not say that this should be the last word, but I believe that it would be well for us if it were at least the first and the middle word in the attempt to carry out our task. We should aim at keeping up the continuity of Christendom. It is rather like the case of the ideas which a dutiful son inherits from his father. He will start from them, and try all he can to make them his own, but he will not be bound by them in the sense that his ultimate statement, at the end of all his trying, will not deviate 
from them to the right hand or to the left. In the last resort, we must do our own thinking, if it is to be sincere.

In like manner as to the 'marching route'. We all have our marching route prescribed for us to a certain extent ex parte ante, if not ex parte post. We all set out from the same camp; and it is something-a substantial something-to remember that this camp is behind us. But, apart from that, although it is right that our marching route should leave us a certain amount of latitude, we don't want to be always going off at a tangent; we don't want our course to be a perpetual zigzag. Liberty should not become licence.

I have only tried to define what I think in general terms; there will be particular considerations in particular cases. But what I have said may perhaps suffice for general guidance, so far as I can give it.

On the more special question, much as I naturally sympathize with the Positive theologians, I am afraid that I cannot say that either their lines of argument or their catchwords seem to me to be happily chosen.

The two main counts in the indictment against Liberalism (i.e. the modern Liberalism, as represented by such names as Wernle, Bousset, Weinel) are: (i) that it makes our Lord Jesus Christ too much the subject of faith rather than the object; and (ii) that Christianity is too much in danger of being lost in the general history of religion.

The use of 'subject' and 'object' in that kind of connexion is at best clumsy. Some years ago the view was put forward by Haussleiter that 'I $\eta \sigma o v$ 
in the phrase $\pi i \sigma \tau \iota s$ 'I $\eta \sigma o v$ was a subjective genitive, meaning 'the faith (i.e. in God) which Jesus held, which was the foundation of His character'. Bousset dismisses this as not worth considering; and I have little doubt that he is right; the phrase means 'faith in Jesus, the faith which has Jesus for its object'. We shall I think best understand what is meant by making Christ the subject of faith by the help of a phrase of Seeberg's which is eagerly caught at by Bousset as offering some chance of an understanding. ${ }^{1}$ Seeberg says, 'Jesus was the first Christian, and $\mathrm{He}$ was the only believer in the full sense of the word'. We remember by the way that Wellhausen ${ }^{2}$, with a different intention, says 'Jesus was not a Christian but a Jew'. We can see what he means; in the mouth of Bousset, Jesus as the 'first Christian' means that $\mathrm{He}$ was the first to teach and cherish the full Christian ideal, to set the example of a Christian life. We believe, and Seeberg believes, that more is involved than this. Almost in the same breath Bousset himself confesses that that was not St. Paul's view of the matter. He did not think of Christ as representing just a new type of piety.

The other count is that Christianity is treated, or is in danger of being treated, as only one phenomenon by the side of others in the general history of religion. On this head, if I understand aright, the objection seems to me to go too far. Kaftan appears to speak with hesitation about the Old Testament, and about the relation of Christianity to other religions generally.

1 Theol. Rundschau, 1906, p. 417.

${ }^{2}$ Einl. p. I 3. 
He widens the gap between them as much as possible, and insists upon the isolation of Christianity. In this I cannot go with him. I believe that we have no reason to hesitate about the Old Testament. Hesitation comes from looking too much at what Old Testament religion rose from and too little at what it rose to. And, perverted as other religions may be in greater or less degree through the presence of evil which affects everything human, I have yet no doubt that they too enter into the great providential order of which Christianity forms the climax. I can far more nearly accept the profession of faith that is given by Bousset, who speaks of a world of reality 'in the midst of which stands the form of Jesus of Nazareth as the crown of a great connected history or series of events (Geschehens) which leads up to $\mathrm{Him}$, and as the beginning and fountain-head of a working of the Spirit that reaches down to ourselves, that carries us with it and takes hold upon us' (p. 294). If Bousset and his friends would only take a statement like that in full earnest, I think we should have no need to complain of them. But do they quite take it in earnest? According to Bousset, their position rests on two main pillars: on the one hand, upon the impression made by the historical Person of Jesus; and on the other hand, upon the experience of religious people in our own day. I may not be quite satisfied, either with the way in which he would define the impression of which he speaks or the way in which he would describe the contents of the religious experience. I shall come back to these points, or at least to one of them, later. But 
I am far from undervaluing the opening that they present for reconciling the opposing views. It seems to me, however, that yet a third factor is needed, and that this is really implied in the profession of faith that I have just quoted, if we may only assume that it means all it says. This third factor is Continuitythat continuous influence which binds together the incarnate Life of the Founder of our religion nineteen centuries ago and the religious experience of us $\mathrm{His}$ followers. I could not possibly express this bond of continuity better than by the very phrase which Bousset uses when he calls it a Geisteswirkung or working of the (Holy) Spirit.

But then, I cannot help asking, if there is this continuity of Divine influence from the first days of Christianity downwards, can it be right to take quite such a leap as Bousset and his friends take, to disengage themselves as much as they do from the main stream of Christian continuity, and to sprinkle quite so many 'nots' as they would sprinkle over the documents which express it, in other words over the Christian Creeds?

I have really a great regard for these men. I greatly appreciate the intellectual sincerity which I know to be at bottom their motive. I understand why they reject the advances which writers like Kaftan and Seeberg make to them. I am well aware of the weakness to which all this Vermittelungstheologie, or 'mediating theology', is exposed. And I am also aware that they would call what I have to offer them by that name. And yet I should very much like just 
to state the case as it seems to me from our side, and to try if we cannot understand each other better.

In the first place there is one ugly word that I should like, if I can, to remove out of the way. It is not, I gather, their own word, but is taken over from their opponents. The word is 'contradictory', which occurs in several different contexts. Here are three of them, from Bousset's article in Theol. Rundschan (1906).

Has K., he asks, the audacity to pronounce the leaders in the history of O.T. revelation, in contradictory opposition to Jesus, as only springing from below? Or is there not here implied everywhere a divine 'from above', only with the distinction of less and greater perfection until we come to the highest perfection of all as expressed in Jesus? (p. 300).

Let us banish from our minds the whole idea of 'contradictory opposition to Jesus'. The reason why Kaftan, and I am afraid Seeberg too, have ever been led to entertain such an idea at all, is because they have so watered down the conception of inspiration that it has ceased to enter into their thinking. Bousset congratulates them upon having emancipated themselves from this exploded dogma. $\mathrm{He}$ is himself, of course, wholly emancipated. And yet, in this very passage, he expresses it himself in set terms, and even makes it the very basis of his reasoning, when he speaks of the 'divine from above' which points forward to a still higher Divine.

There is another statement of their own which I would invite all those whom it concerns to perpend, 
and give it its full weight. If they would only do that, I have no doubt that we could come to terms.

Now for another example of the use of the word ' contradictory':-

Has one really the right to place the Christian religion in a declared contradictory, absolute opposition to all other religious life? (p. 4I3).

Most certainly we have no such right. The recognition of that ought to be a truism.

Here is a third example, which has perhaps more excuse, and yet only an excuse :-

S. begins his Christology as usual by maintaining a contradictory opposition between Jesus and all the rest of mankind: on one side Humanity, under the universal domination of $\sin$, and on the other side the One, the sinless One, the Saviour (p. 416).

Who is it that speaks of 'contradictory opposition' even here? Certainly not St. Paul, when he says: 'God, sending His own Son in the likeness of sinful flesh... condemned $\sin$ in the flesh' (Rom. viii. 3). We note that St. Paul makes just this one exception of Sin: he implies that in all other respects the humanity of Christ was like our own. It remains, indeed, a problem for theologians, how far that exception goes -precisely how much it covers (see pp. 305 f.inf.). But the problem is one that need not trouble ordinary men, and that most theologians may be content to leave unanswered. But imagine St. Athanasius or St. Augustine speaking of a 'contradictory opposition' between the humanity of Christ and our humanity! 
I need not say that, on the contrary, the substantial identity of His humanity and ours was of the very essence of their teaching. I am afraid that, on such points, the ancients were more exact and careful thinkers than the moderns.

Bousset has a great deal to say about Wirklichkeitssinn or 'sense of reality', which he seems to think can be applied with the greatest ease by light of nature to most problems of history and of philosophy. That involves the rather large assumption that we know all that is included in the world of reality, and that the laws we deduce from the contemplation of those parts of it that come within the range of our senses can be applied with equal justice to those parts of it that do not. In other words Wirklichkeitssinn, for which I suppose the plain English equivalent would be 'common sense', means, as it does so often, just a big begging of the question, a taking for granted of the real point at issue. Bousset himself (Fesus, pp. 198-20I) sets down a number of points in which the Life of Christ differs from and transcends other human lives : but he does not seem to inquire how far these differences imply something further and more fundamental which may well interfere with the stringent application of those human analogies, which is what the Wirklichkeitssinn really means.

But in case we distrust these rather masterful methods, if we hold our presuppositions under control and do not allow them to decide for us large questions almost before they are asked, then we are thrown back upon the more laborious processes of historical inquiry. 
Now I do not say for a moment that Bousset and his friends are not experts in the study of these processes. There is a great deal in the study of them that I admire very sincerely indeed. I am aware too that not only Bousset and his friends but a great many in this country as well look upon persons like myself as hampered and trammelled by all sorts of illicit influences from which they are happily free. But, strange as it may seem to say so, I sometimes find myself feeling as though the tables were turned and I had greater freedom than they. There is that awkward Wirklichkeitssinn, which has a way of turning up at every corner, and pronouncing what you are to believe and what you are not, before you can get the normal apparatus in such matters to work; or perhaps the apparatus has been at work for some little time, and a certain conclusion appears to be pretty plainly indicated, when the Wirklichkeitssinn rises up on a sudden and moves the closure-applies the guillotine, as I believe it is called in parliamentary language-and stops all further debate, imposing some conclusion which is not what the facts appear to point to.

I will give an example-a striking example, as it seems to me-presently. But, before I do so, I should like to say something seriously about Bousset and his friends. I am deeply interested in them, and I believe that at bottom we are not so far apart as we may seem.

We in the Church of England, who have not yet ceased to think much of the Christian tradition, are apt to have our language discounted-and to some extent justly discounted-when we express ourselves 
in terms of that tradition. We repeat the language of the Ancient Faith, though we expect to have some allowance made for the difference of times.

To take a prominent instance; the young clergyman, when he is ordained, says that he believes all the Scriptures of the Old and New Testaments. And he does really believe them: he believes that the Bible is an inspired book, that God really speaks through it, and therefore that it is rightly called God's Word; that he can find there all that is necessary for his soul's health. This he does believe, and it is what he means when he makes his profession. But it is not exactly what our forefathers believed, and not what the authors of the Ordination Service believed. A certain process of simplification has taken place; and a similar process of simplification has taken place elsewhere. Of course it is a nice question to distinguish between legitimate simplification and that which is not legitimate. I do not go into that question now. My point is that our language in such cases may be rightly discounted. I shall not be misconstrued if I put it in the form that we believe, and are understood to helieve, rather less than we seem to say.

But, in the case of these German Lutheran writers, if we discount their language, we may fairly I think discount it the other way; I mean, take it as meaning rather more, and not less, than it says in plain words.

They have pretty well discarded the Christian tradition; for practical purposes, it has but little influence upon them. I should imagine that there are very few who would take their opinions from the 
Creeds, simply because they were the Creeds. On the other hand, they have a very high academic standard of intellectual sincerity. Every one feels bound to say exactly what he thinks, by his own thinking, independently of any external authority. Public opinion backs them up in this; it almost compels them to be not only candid, but even more than candid.

No doubt there are a good many in this country at the present time who take much the same line. Perhaps German influence, the tone of the German Universities, has had something to do with it. But, apart from that, innate honesty, of which I do not believe that we have any lack, was sure to bring about substantially the same result. It is probable enough that I was describing just now the state of things forty years ago rather than the state of things to-day.

However that may be, the upshot is that in the case of the Germans and those of our countrymen who think and act with them, it is only right to take language as a minimum, which in the case of others of us would be taken as a maximum. I believe that we may often credit both our German friends and our very candid English friends with rather more than they put into express words.

Accordingly, I take it with a grain of salt when some of the writers of whom I have spoken insist, as we might describe it, on putting 'nots' into the Creeds. I take the liberty of interpreting their language in these cases in the light of their language elsewhere; and I make some allowance for the Wirklichkeitssinn, where 
that intrusive quality seems on their own showing to be out of place.

I know that Bousset says more than once that the life of our Lord did not overstep the limits of the purely human (pp. 202, 203). But has he the right to say this? Does it not flatly contradict the facts as he himself states them? And does he not seek to prevent it from doing so by expedients that are quite unjustifiable?

We remember that Bousset is not one of those who explain away the Messiahship of Jesus. He not only allows distinctly that our Lord thought of Himself as the Messiah, but that His consciousness took this form naturally and, as it were, inevitably. He speaks of it as 'the form in which an eternal meaning clothed itself'. He speaks of the title of Messiah as 'necessary to Jesus in its general aspect, apart from certain details : because it alone coincided with his consciousness of his own unique position and super-prophetic significance'. And then he goes on :-

Let us contemplate for a moment this sovereign sense of leadership by which Jesus was possessed, and the inimitable sureness with which it unfolded itself in every direction. He knew how to value the authorities of the past, but he placed himself above them. He was of more account than kings and prophets, than David, Solomon, and the Temple. The tradition of the elders he met with his 'But I say unto you', and even Moses was not an authority to whom he gave unqualified submission. As with the past, so too the present bowed before him. John the Baptist he thought the greatest among the sons of men, yet it was not Jesus who put the question, 'Art thou he that 
cometh ?' to John, but John to Jesus, and he answered the inquiry with a veiled though yet distinct affirmative (p. 199).

And two more pages of the English translation are given up to indications of the same kind, ending thus : 'Such words either come from thoughtless presumption or from the very highest strength and confidence. History has decided for the latter.'

You will have observed in the passages that I quoted a number of strong expressions: 'eternal meaning,' 'unique position,' 'super-prophetic significance,' 'sovereign sense of leadership.' Is there here no overstepping of the human? There is indeed one very paradoxical bit of evidence alleged to the contrary. It is expressed as follows :-

Above all he did not lay claim to the Judgeship of the world, although that conception was, strictly speaking, included in that of the Son of Man. It is true that in the narratives of our Gospels the opposite seems to be the case. But it is inconceivable that Jesus ... should now have arrogated to himself the Judgeship of the world in the place of God (p. 203).

Is this really following the evidence, or forcing the evidence? The Gospels certainly say one thing, but they are treated as if they said the opposite. I know that an ingenious theory is propounded to explain how from one step to another innocent expressions might have been taken to mean more than they really did. But I am afraid that no one, merely from reading the Gospels, would have been led to explain the facts in this way. The real motive is subjective and not objective: it is our old friend the Wirklichkeitssimn, 
standing where it ought not and thrusting itself into regions that are beyond its range. It is not the Gospels which say that our Lord did not lay claim to be the Judge of the world, but Bousset whose presuppositions will not allow him to think that $\mathrm{He}$ could have put forward such a claim.

The title 'Son of Man' is robbed by a tour de force of half its meaning. And precisely the same thing has happened to the title Messiah. We are told that the assumption of this title was a necessity :-

Jesus felt that he stood in such closeness of communion with God the Father as belonged to none before or after him. He was conscious of speaking the last and decisive word; he felt that what he did was final and that no one would come after him. The certainty and simple force of his work, the sunshine, clearness and freshness of his whole attitude rest upon this foundation. We cannot eliminate from his personality without destroying it the trait of super-prophetic consciousness, the consciousness of the accomplisher to whose person the flight of the ages and the whole destiny of his followers is linked. And when Jesus wished to give form and expression to this consciousness, and thereby to lift it from its state of fermentation into one of clearness and stability, the only possibility that presented itself to him was that of the Messianic idea,- - of that figure of the kingly consummator standing at the end of time, as popular imagination had painted it with its earthly colours (p, I 79).

And then, by way of summing up, we have a paragraph which because of its importance is printed in italics by the author:-

Thus the Messianic idea was the only possible form in which Fesus could clothe his innor consciousness, and yet 
an inadequate form; it was a necessity, but also a heavy burden which he bore in silence almost to the end of his life; it was a conviction which he could never enjoy with a whole heart (p. I 80).

There is no doubt one historical moment with reference to which Messiahship might be thought to be a burden. But I do not believe that the author is thinking of Gethsemane. He is thinking of the twentieth century, and its ideas of what constitutes a burden. I can quite imagine that if (let us say) some modern Jew, a Zionist leader, suddenly found himself invested with Messianic powers, he would be troubled by them, and would not know what to do with them; he would be like David in Saul's armour. I suppose it is something of that kind that Bousset has in his mind. But the Gospels are quite different. There is no hint in them, throughout the main tenor of His ministry, that our Lord felt His Messiahship a burden. The Sermon on the Mount conveys no such impression; still less does that thanksgiving recorded by St. Luke, 'I thank Thee, $O$ Father, Lord of heaven and earth, that Thou hast hid these things from the wise and prudent, and hast revealed them unto babes: even so, Father; for so it seemed good in Thy sight' (Luke x. $2 \mathrm{I}$ ).

The whole notion of a burden is pure modernism of the most gratuitous kind. That was not the way in which our Lord thought of the work that the Father had given Him to do.

I have just taken Bousset as an example, and he is one of the best of his kind. What applies to him will apply also substantially to his friends and allies who. 
seem to be at the present moment the dominating influence in the German Universities. I think, however, that (as I said) we can put a better construction upon their work than we could if we were to take them literally at their word. I value greatly the positive elements in their construction. The data have been searched with the severest scrutiny possible. And as a result, two things stand out more clearly and more indisputably than ever. One is the consciousness of our Lord as Messiah; and the other is His consciousness as Son. I should like to commend to you a work that came out early in the present year, an examination of these two leading conceptions by the veteran scholar H. J. Holtzmann, Das messianische Berwusstsein Fesu (Tübingen, 1907). The book bears the stamp of its author's characteristic excellences. It is crowded with learning, and full of subtle analysis and subtle differentiation of competing views. The treatise is, unfortunately, just because of these qualities, difficult reading; but I do not know anything at once so comprehensive and so exact. And, considering the quarter from which it comes, the whole tenor of the discussion appears to me to be positive and satisfactory to a degree beyond what might have been expected. The formula in which Holtzmann sums up his final result (p. 100) is that Jesus was 'the Messiah and more than a Messiah', just as His forerunner the Baptist was a prophet and more than a prophet (Matt. xi. 9, Luke vii. 26). The writer who recognizes that, and recognizes it in those terms, seems to me to have the root of the matter, whatever else he may say. 
Two things are impressed upon me, in looking back over Holtzmann's book and the immense variety of opinion which it registers. One is that, if we put aside a minority which is so small and so unimportant as to be really negligible, even those who still challenge our Lord's adoption of the express title Messiah, do so only by first defining the idea contained in it in a sense that is rigorously Jewish, while they naturally go on to deny-as with perfect right they must deny-that our Lord took to Himself the title in this sense. Those of whom I speak, if they refuse to describe the consciousness of our Lord as Messianic, do not therefore reduce it simply to the common level, but acknowledge in it heights and depths to which they only abstain from giving an explicit name.

That is the first remark that occurs to me: the second is perhaps more subjective in the way in which I shall state it; it is an impression borne in upon me personally by the almost endless multitude of points insisted upon now by this writer and now by that. It seems to me that almost every one of these points, subtle and remote as some of them may be, has something substantial to say for itself. Especially is this the case with that central title 'Son of Man'. We must never forget that this is the name which our Lord chose specially for Himself, and which $\mathrm{He}$ appears to have preferred above every other. The other names $\mathrm{He}$ purposely kept in the background; but this He used freely and without hesitation, though even this $\mathrm{He}$ employs objectively and in the third person, hinting rather than expressly claiming that 
in speaking of the Son of Man He is speaking of Himself.

That being so-the name being our Lord's own choice, and not that of others for Him-we cannot, I think, be surprised at its extraordinary wealth of meaning. For my own part, I should hardly put any limit to this. No doubt there are differences of proportion and perspective; some parts of the idea are nearer to the centre, and some lie more upon the circumference; but it seems to me that hardly anything that has ever been attributed to it is wholly without at least a certain relative justification.

Let us think for a moment how many distinct lines of association meet in this one phrase. First there is its use in the Old Testament-its use collectively for the race of mankind (as in Ps. viii. 4), and then its use individually (as conspicuously by the prophet Ezekiel). I myself greatly doubt whether there is a single instance of its use from which some darting ray of association does not shoot across from the Old Testament into the New.

Then there is our Lord's use of the phrase with reference to His own immediate present; as well the sense that would attach to it in current opinion (though I agree that, while it was employed for special purposes from time to time, it was not exactly in general or common circulation) as the sense in which He applied it to the circumstances of His own daily life (e. g. ' the Son of Man hath not where to lay His head').

And, thirdly, there is the yet larger sense attaching to the phrase in such connotation as it had which 
pointed forward definitely to the future. I should venture to go beyond the Jewish connotation of this kind, and to express my belief that while our Lord included this (with modifications of $\mathrm{H}$ is own into which we cannot wholly penetrate) $\mathrm{He}$ at the same time gave it a turn that prepared the way and supplied a broad foundation for those later attempts that Christendom has made to express in terms of its successive thought its sense of the ulterior mystery of His Person.

In this last connexion I will go on to make a yet further remark which has of late suggested itself to me, and which I am inclined to think of really great importance, especially for that kind of critical investigation in which we have been engaged. We are in the habit of asking, what does this or that phrase or title mean? and we go on to attempt to answer the question as though it could have but one meaning, and that fixed and definite, which, when once we realize it, must of necessity exclude all others. But the fact isI do not stay to speculate how far it may be true of other fields of inquiry, but I am sure that it is true, intensely true, of this-that each word or phrase of the kind of which I have been speaking has many meanings, determined in most cases by the persons from whom they proceed or to whom they are addressed. And I am persuaded that in each case, when we try to envisage a particular meaning, the first thing that we have to do is to ask ourselves whose meaning we are in search of, What does the word or phrase mean, and for whom? This may seem an obvious thing to say; 
and it is no doubt true that writers and thinkers constantly do ask themselves this question. Still I believe that they ought to do so more persistently than as a matter of fact they do; and that the failure to do this has been a plentiful source of error and confusion.

If I am not greatly mistaken, it lies at the root of a great deal of the inadequacy which seems to me especially to attach to liberal theories over the field that we have been covering. These theories are at bottom attempts to modernize; they are attempts to state ancient facts in terms in which they can be best understood and best appropriated by modern men. I have no quarrel with them whatever for this. Sooner or later we must all come to it. What I am really inclined to complain of is that the scholars and critics who make a point of doing this, for the most part do it too soon. They allow their modernizing to be mixed up in the statement of ancient facts, whereas they ought in the first instance to state these facts strictly as they are, i.e. as ancient. We moderns ought to begin by using every effort of reason and imagination to throw ourselves back into the times that we are investigating and to look at men and things, practices and ideas, strictly in the light of their own context; we ought to exclude ourselves from the process as much as we possibly can. First, let us state the facts with the most sympathetic reconstruction of which we are capable of the real conditions by which they were surrounded, the conditions as they would present themselves to an observer at that day. They may seem to us rude and crude. Never mind ; our first business is 
to take them as they are, with their own proper atmosphere, and with no admixture of ours. If we are to do anything, let us rather exaggerate the significance that particular phenomena seem to have; that will be at least better than diminishing from it. Let us try to make our picture as full and as boldly drawn as it is in our power to make it.

Then, when once we have done this and are satisfied that we have nothing to add-then, and not before-the time will come to apply it to ourselves. Then, and not before, we may begin to ask what these facts, or series of facts, mean for us. This is what the Liberals are doing; and I would find no fault with them if they would take the process in that way. Only one thing, in connexion with this Christian history which so nearly concerns us: I would beg them to ask not only what it meant to the men of that time, spectators or disciples. Behind the disciples is $\mathrm{He}$ of whom they were disciples. Let us ask, in all reverence, and without too much intrusive Wirklichkeitssinn, what it all meant for Him. We may ask the question, we may ask it even with some importunity; but we must be prepared to find ourselves before long brought up short, and unable to give ail answer. This is really the most difficult, as it is the most tender, point of the inquiry. The next great step-audacious as it may seem-is really easier; the step, I mean, of asking what the Disposer of all events designed in all this history. Of course I do not suppose that we can for a moment pretend to discover its place in His counsels considered as ultimate and absolute. But we can, with 
so many centuries to look back upon, see something of their purpose in relation to the history of the human race. Not only is this quite a legitimate, and quite a feasible, subject for inquiry; not only are we encouraged to make it for the interest that it has in itself; but it has also an important bearing upon that application to ourselves of which I have been speaking.

It seems to me-and with this one bit of practical advice I will conclude-that a mistake is made in propounding to ourselves so often that question which we hear on all hands-and that we should hear it so often is a testimony to the mental sincerity that is increasingly characteristic of our age-the urgent question, what is the truth about this or that, what is true. Far be it from me to blame the sincerity. The sincerity in itself is excellent; and I will not say that there is-I am sure that in thousands of cases there is not-any touch of arrogance in the question. And yet I cannot but think that, in asking this question, What is true? we are very many of us not in the least aware what a tremendous thing it is that we are asking. If we were aware of it, I believe that we should many of us refrain our lips; and although that would not be by any means the same thing as suppressing or abandoning the question altogether, I believe that it might often involve putting it by for a later season when we were more ripe to attempt the answer. I can well imagine that what I am going to suggest may seem a less modest form of the question, but I conceive that it is really a more modest form of it. I would ask-at least 
at first and for a long time-not, what is true about this or that, but what did God mean by it, for the Church, for the world, for me. The page of history lies open before us, and we can read its meaning with comparative ease. In doing so, we do not attempt to transcend the limits of the Relative, which is the real point at which the enormous difficulties come in ; and at the same time we fit our thought into that teleological contemplation of the universe which is an endless source of adoration.

And as to such theories as those which the liberal school puts forward, we of course try to correct them to the best of our ability. But in our judgements we recognize the sincerity which prompts them; we make allowance for what seem to us to be in part self-imposed difficulties; we feel justified in putting our own interpretation-as we should call it, the full Christian interpretation-on that collection of significant facts, which is not denied but proved over and over again more imperatively than ever. We take what they give us as a verifiable minimum-a minimum verifiable by the severest methods-and we are glad to think that their admissions show that, whether they exactly formulate the consequences or not, they are really looking out beyond this minimum, as we look beyond it ourselves. 
IV. MIRACLES

VIII. MIRACLES 



\section{VIII}

\section{MIRACLES}

TuE haunting problem of Miracles invites repeated and sustained attempts at its solution. Even a small advance is yet advance; and in some respects the conditions of inquiry are more favourable at the present time than they have ever been before.

The great difficulty, it may be said, is to make both ends meet-on the one hand the presuppositions of science, and on the other hand the presuppositions of religion; on the one hand the data of philosophy, and on the other hand the data of history.

We are modern men, and we cannot divest ourselves of our modernity. We may be sure that we are not called upon to divest ourselves of it. We are placed by God here in the twentieth century. Every opinion that we hold has a vast context of accumulated opinions and beliefs about other things. Our difficulty is, how to correlate and harmonize all these various opinions; and again, how to deal at once sympathetically and justly. with the beliefs of men of another age, whose mental equipment was very different from our own.

This fact-the fact that our difficulty lies where it does-suggests a point of method. It suggests that we shall do well not to isolate a part of our problem, but 
rather to take a broad view of it as a whole. And for this, perhaps, there is advantage in being compelled to treat it with the compactness of a single discourse. If I have to put some slight strain upon your patience, I will try to make it no greater than can be helped. I will try also to state the problem in such a way as to enlist your co-operation in following the inquiry step by step.

I have said that I would not ask any one to divest himself of those ideas which we all naturally bring with us-I mean our ideas as to the uniformity of the ordinary course of nature. I would only ask you to set beside these a single assumption of a different kind, the assumption that every Christian is compelled to make by his own experience, that there is such a thing as answers to prayer. There is no Christian whose experience does not tell him that prayers are answered on a very large scale indeed.

This experience points beyond itself. It points to the conclusion that the Power behind the universe is in touch with human spirits and human wills. It does not prove that God will violate His own laws, but I think it does prove that, within the conditions imposed by those laws, He does interest Himself in human affairs. In other words, there is a reciprocal relationan actively reciprocal relation-between the Power without us and the spirit or personality within us.

When I speak of the reality of answers to prayer, I do not at all mean that every prayer is answered. Our experience is the same in this as in other things; it is that certain classes or kinds of prayer are more 
frequently answered than others; which we may take to mean, that those particular classes or kinds of prayer are more entirely in accordance with the Divine will than others. But the important point is that prayers are answered on such an abundant scale as to place beyond all doubt that reciprocal relation between God and man of which I spoke.

It is a particular form of this relation, not so widespread and yet strongly attested, especially for the earlier ages in the history of mankind, that certain individuals have stood in a closer relation to God than others, that they have received what we call special communications from Him, that they have been made in a higher sense than others the instruments or organs for the carrying out of His purposes.

This belief is of course by no means confined to the Bible. In one form or another, lower or higher, purer or more depraved, it embraces almost all the races of mankind.

And, along with the belief in special communications to individuals, there has gone, as a sort of natural accompaniment, the further belief that these individuals have been gifted with some special power of showing that the mission which they claimed for themselves, or which was claimed for them, was real. They had their credentials, which they were able to produce; and these credentials were for the most part what we call Miracles.

I say that this belief, in its various forms and degrees, is almost as wide as human nature itself. It is expressed very simply and naturally in such a passage 
as Acts ii. 22. We are told there that the Prophet of Nazareth was approved by God to the generation to which $\mathrm{He}$ came by mighty works and wonders and signs, which God did through Him. And in like manner, His follower St. Paul speaks of the signs of an apostle which he had himself wrought 'by signs and wonders and mighty works' (2 Cor. xii. 12). The crowds said of our Lord in reply to the strictures of the Pharisees, "How can a man that is a sinner do such signs ?' (John ix. I6). And again, the blind man who was healed says: "We know that God heareth not sinners : but if any man be a worshipper of God, and do His will, him He heareth. . . . If this man were not from God, he could do nothing' (ibid. vv. 3I, 33). The belief which thus finds expression in the New Testament is just the common belief of antiquity, with the moral side sharply accentuated. It is an integral part of that whole group of ideas which affirm the reality of communication between God and man, and the presence on earth of inspired men who are the special channels of such communication.

The most conspicuous pagan example of a worker of miracles is Apollonius of Tyana, who lived through the greater part of the first century of our era. His biography, by Philostratus, is rather more than a hundred years later, but professes to be based upon materials left by the most intimate of his personal disciples. It is a mistake to suppose that the Life was written with any deliberate purpose of rivalry to our Lord, though it was utilized in that sense in the acute stage of pagan and Christian controversy at the 
beginning of the fourth century. The life is a strange mixture of modest claims-A pollonius did not profess to be more than a sage and good man, and only divine in the sense in which any good man might be divineof ascetic and irreproachable conduct, of shrewdness approaching at times almost to wisdom, with puerilities both of teaching and of practice, and with fantastic stories of the marvellous. These reach a climax in the account of the Indian Brahmins, whom Apollonius visits in his search for what is left of primitive wisdom; but he himself has the power of predicting events, of exorcizing demons, of putting down ghosts and lamiac (it will be remembered that Keats's poem 'Lamia' is based on one of the stories); on one occasion he causes a pestilence to cease by indicating the appropriate sacrifices; he is transported from place to place; he can at will release himself from fetters.

The sage is often called a magus, both in pagan literature and in Christian (e. c. by Origen); but the Life tries to vindicate him at least from anything discreditable implied in the title. The evidence has been accumulating in recent years of the wide prevalence of magic under the early Empire. Besides what has come to light through a closer study of the literature, magic holds a large place among the documents of common life discovered in Egypt and elsewhere. We owe especially to Sir W. M. Ramsay the warning that we clo wrong to think of everything magical as pure imposture and delusion. Let me quote a few lines from the comment in St. Paul the 
Traveller (pp. 77 f.) upon the meeting between St. Paul and the Magian Bar-jesus. The latter

is commonly said to be a magician, a mere 'Jewish impostor'; and he is compared to the modern gipsy teller of fortunes. Such comparisons, while having a certain element of truth, are misleading, and give a false idea of the influence exerted on the Roman world by Oriental personages like this Magian. . . . No strict line could then be drawn between lawful, honourable scrutinizing of the secret powers of Nature and illicit attempts to pry into then for selfish ends, between science and magic, between chemistry and alchemy, between astronomy and astrology. The two sides of investigation passed by hardly perceptible degrees into one another. . . . It was not possible in the infancy of knowledge to know where lay the bounds between the possible and the impossible, between the search for the philosopher's stone or the elixir of life and the investigation of the properties of argon or the laws of biology.... It is certain that the priests of some Eastern religions possessed very considerable knowledge of the powers and processes of nature; and they were able to do things that either were, or seemed to be, marvellous.

Sir W. M. Ramsay adds that his own experience makes him believe that, 'so far as influence over human or animal nature and life was concerned, their powers were wonderful.'

That passage is, I believe, very far from being the least of the many debts that we owe to its accomplished author, whose knowledge of ancient life is so profound.

Undoubtedly there was this side to ancient magic. Nor would it be true to say that there was no insistence upon moral conditions as necessary for the 
exercise of superior powers. The history of A pollonius would be evidence to the contrary. But, at the same time, these conditions certainly were not laid down with the clearness and firmness that characterize the passages quoted a little while ago from the Gospels. Speaking broadly, I am afraid it would be true that magic presented the lower and baser side of ancient religion. The higher elements were, I suspect, the exception, and the lower elements the rule. Both on the part of priests and people, of the magi themselves and their clients, the worse passions and motives were brought out rather than the better. I have in mind the large extent to which the specimens of magic that have come down to us are either erotic or imprecatory. Of course in any general estimate we must simply follow the evidence. But I do not think it will be denied that Biblical Religion stands upon an altogether higher level, even from its earliest stages onwards.

With so much of preface on the comparative aspect of the question, we may now go on to trace the history of Miracle as we find it in the Bible, first in the Old Testament and then in the New. I believe that we shall find the advantage in each case of considering the Miracles as they come before us, not in the abstract, but with reference to their place in the history and the evidence upon which they rest.

The early chapters of Genesis stand rather apart, as falling under the head of what may be called 'symbolical history'. Putting these aside, the miracles of the Old Testament fall into four groups: (i) the 
miraculous narratives of the Hexateuch, including the Exodus, the Wanderings with the Giving of the Law from Mount Sinai, and the Conquest of Canaan; (ii) the Elijah- and Elisha-narratives; (iii) the supernatural element in the lives of the Prophets; (iv) a few miracles that may be called 'literary', like those in the Books of Jonah and Daniel.

With the exception of a few fragments, like the songs in Num. xxi, the oldest portions of the Hexateuch are probably separated from the events by several centuries, hardly less than four. It would follow almost inevitably that the story has come down to us very largely in the form of folklore, as a product of oral tradition. It need not be on that account, and certainly is not, any the less a vehicle of divine revelation. The Holy Spirit made use of folklore, as it made use of other natural forms of Hebrew literature, to convey the lessons which God desired to have taught to His people. We only need to think of the story of the Burning Bush, of the Decalogue, of the concluding of the Covenant in Ex. xxiv, and of the proclamation of the Divine Name in Ex. xxxiv, to be assured that this was so. Neither is there any reason to question the strong belief which overshadowed the whole later history of Israel, that the deliverance from Egypt was a great interposition of Providence, and that the nucleus of the Pentateuchal legislation was a special work of divine inspiration initiated by Moses. At the same time, the details of the narratives as we have them show evident signs of the kind of shaping that would be natural to folklore. This appears, for instance, in the artificial 
numeration and gradual crescendo of the Ten Plagues, and in the highly poetic description of the Giving of the Law from Sinai, modelled upon the standing symbolism of Hebrew theophanies (the storm-cloud, fire, lightning and thunder, as in Ps. xviii, \&c.), and in the equally poetic description of the battle of Bethhoron and the lengthening of the day in Joshua $x$.

The histories of Elijah and Elisha are much nearer -indeed quite near-to the events. And yet the difference is one of degree rather than of kind. Here, too, an element of folklore has entered in ; especially in the case of Elisha (e.g. 2 Kings ii. 19-25). But, along with this, not only are the general narratives at a high level as the history of a crisis, at once of religious and of political history, but they also embody incidentally notable revelations, as to Elijah at Horeb, to Elisha's servant at Dothan, in the story of Gehazi and the like.

From a religious point of view, the culminating instances of the supernatural in the Old Testament are in connexion with the writing prophets; for instance the vision, which accompanied the call of the leading prophets (Isa. vi, Jer. i, Ezek. i), the communion which they are represented as habitually holding with God, and the peculiar insight into $\mathrm{His}$ counsels with which they were endowed. But there are also definite predictions, literally fulfilled (e.g., the destruction of Sennacherib's army, or Jeremiah's denunciation of the false prophet Hananiah). It was never intended that we should take literally such 
things as Jonah and the whale, or the celestial journeys of Ezekiel (ii. I 2; viii. 3; xi. I, 24; xxxvii. 1; xliii. 5). That these things should have been taken literally at different periods in the history of the Church does not affect the matter; because from the first the stress lay upon the moral lesson conveyed, and not upon the reality of the occurrences as history.

As we look back over these Old Testament miracles, we cannot help noticing how the evidence for them becomes stronger as they approximate to the type supplied by answers to prayer. The conclusion most effectually proved is that of the extraordinary personal endowment of certain chosen individuals, and especially of their extraordinary communion with God and knowledge of $\mathrm{His}$ will. The providential focussing of natural processes upon a particular point and for a particular end is also well attested; but the cruder interferences with natural law elude our grasp.

In turning to the New Testament, we shall still do well to follow the obvious classification according to documents: (i) the miracles of the Gospels, or, more strictly, of the critically separable documents which underlie our present Gospels; (ii) the miracles of the Acts, both those parts of Acts in which the author speaks as an eye-witness, and those in which he does not-for I think I may assume the thesis so consistently maintained by English scholars and now strongly defended by Harnack, that St. Luke was really the author of the whole book; and (iii) the 
scattered allusions to miracles that occur in the Epistles of St. Paul.

Both jointly and severally these three classes contain a number of miracles, the evidence for which is exceedingly strong.

In the Gospels we have a convergence of evidence from every one of the larger documents or literary strata that criticism indicates. And the evidence, which is so considerable in quantity, is excellent also in quality. It is not only the direct evidence of narrative, but the still more important indirect evidence of discourse, which implies the existence of miracles. It is also evidence of a very restrained and trustworthy kind ; the Gospels certainly do not make too much of miracle, but are very careful to keep it in a subordinate place. We may well doubt whether, without miracle, the belief would ever have grown up that Jesus of Nazareth was the Messiah, in view of the striking absence of those attributes and functions which the Jews expected in their Messiah.

And yet the Gospels, good as their credentials are, stop short of evidence that is absolutely at first hand, unless we insist upon statements in the Fourth Gospel which are still called in question. But, however that may be, the defect is made good in the Acts and Epistles. On the one hand, we have a number of miracles dating from the time when St. Luke himself was actually in the company of those who performed them. And, on the other hand, we have express statements by St. Paul in which he is speaking from his own personal experience and personal knowledge. The 
charismata included gifts that every one believed to be miraculous, and St. Paul himself possessed these gifts in an eminent degree.

For the purposes of history, we can only take that state of things as it stands. The picture that we form for ourselves of the history must include the sincere and convinced belief of those who were actors in it. Their good faith cannot be reasonably questioned. Nor can we doubt that their whole attitude of mind towards these things which they saw with their own eyes, and heard with their own ears, and did with their own hands, was the attitude of men who believed themselves to be in contact with miracle. Their settled assumption was that no one could do such things unless God were with him.

As historians, we have no need to analyse the consciousness of these men any further. The only question is as to our own consciousness : how are we to look at and describe to ourselves these phenomena of which the record has come down to us? We shall try, I think, to do justice to both sides : we shall so far hold our own ground as not to postulate anything that would radically conflict with our conception of nature; but we shall not, on that account, allow ourselves so to impose our presuppositions upon the first Christians as to do violence to their convictions.

Let us take the two latter of our three classes of miracle, those from time to time alluded to in the Epistles of St. Paul, and those narrated in the 'Wedocument' or Travel-diary of the Acts. Here, the testimony of St. Paul is absolute, as coming from one 
who was himself a miracle-worker; it is only qualified in so far as his descriptions are vague and general. It is certain that he believed miracle to be a characteristic. phenomenon of the agre in which he lived and of the circles in which he moved. It is also certain that he fully believed himself to be gifted with the power of working miracle. The one drawback is that he has not left any full and exact record of the feats which he regarded as miraculous.

On the other hand, the testimony of St. Luke is absolute in so far as his narrative contains sufficiently cletailed descriptions - it is at least as absolute as an honest eye-witness could make it; it is qualified in so far as the miracles which he relates were not actually worked by himself. We are indeed led to infer that some of the cures accomplished upon the island of Melita were of cases that came under his own hand in the active practice of his medical profession. Harnack has noticed a delicate little touch which points to this. ${ }^{1}$ Whereas the first person is generally rather suppressed, and whereas the healing of the father of Publius is expressly referred to St. Paul, we are told that, "when this was done, the rest also which had discases in the island came, and were cured [rather, ' received medical treatment': Ramsay]; who also honoured us with many' honours.' St. Luke himself was one of those towards whom the islanders were specially grateful. Obviously he had used his professional skill, and he believed that God had worked with him.

It is true that here again the description becomes 1 L.ukas der Arzt, p. I I. 
vague and summary. And yet, taking the double testimony together of St. Paul and St. Luke, its cogency must be allowed to be very considerable. The burden of question seems to fall rather upon us in these latter days. What have we to say in reference to these miracles, which appear to be so amply attested?

Before I attempt to answer this question, it may be well for me to ask your attention to a remarkable, farsighted, philosophical passage in St. Augustine, which shows that we moderns have no monopoly of deeper thought on the relation of miracles to the uniformity of nature. In De Civitate Dei, xxi. 8, St. Augustine writes :

We say that all miracles (or prodigies, portenta) are contrary to nature; but that they are not. For how can that be contrary to nature which takes place by the will of God, seeing that the will of the great Creator is the true nature of everything created? So miracle is not contrary to nature, but only to what we know of nature (contra quam est nota natura). ${ }^{1}$

Miracle is not really a breach of the order of nature; it is only an apparent breach of laws that we know, in obedience to other and higher laws that we do not know.

If, with this principle in our mind, we examine the miracles of St. Luke's Travel-diary, we shall find them fall under it perfectly. We shall find that they do not imply anything really irregular or arbitrary. We shall find that they come strictly under the analogy of answers to prayer.

${ }^{1} \mathrm{My}$ attention was first called to this passage by Barth, Hauptprobleme d. Lebens Jesu (1899), p. I I 5 . 
Let us run rapidly through this little group of miracles, and we shall see that this is true. The incident of the soothsaying girl at Philippi is psychologically quite intelligible. Her exclamation at the sight of St. Paul and his companions, 'These men are servants of the Most High God,' is very parallel to the exclamation of the possersed man in the synagogue at Capernaum, 'I know thee who thou art, the Holy One of God.' Patients of this sort often have a quick eye and ready intuition for high degrees of goodness; it is just that which renders them susceptible to personal influence. The earthquake that broke open the doors of the prison was only a natural event timed opportunely. When St. Paul preached at Troas, and Eutychus fell from the upper story, the apostle perceived that life was in him, though those who took him up thought him dead. I suppose we should now say that he was probably suffering from 'concussion of the brain '. The prophecy of Agabus (Acts xxi. 11 ) is an example of a gift that was common both under the Old Covenant and the New. The events of the shipwreck were providentially ordered, but none of them 'against nature'. And the same would be true of all that happened on the island of Melita. The simplest explanation of the incident of the viper would probably be that a non-poisonous snake was mistaken for a poisonous one; and the facts recently collected by Sir William Ramsay will show that this might easily have happened.' The healing of disease is one of the best authenticated forms of miracle; but it, if anything, is

1 Expositor, 1907 , i. 122 f. 
a case of one set of natural forces counteracting another. These, I think, are all the miracles for which we have a voucher that they took place in St. Luke's presence, and may we not say that not a single one need cause any real difficulty? If it is objected that, on this showing, they cease to be miracles, I answer, Not at all. The essential point is the Divine act; and that, I think, is proved. We are beginning to learn the lesson that an act is not less divine because it is fundamentally in accordance with law. A special providence is a miracle, and fulfils all the true purpose of miracle; it is a real proof of divine protection and divine co-operation - a real mark of a mission from God.

Rather, in these miracles of the Travel-diary we shall see exactly what we might expect to find-a series of events, which towards the men of that day turned the side of miracle and satisfied all the purpose of miracle, and which to us turns the other side of conformity to nature, showing that at least we need not assume any literal dislocation of the established order.

The broad conclusion to which we shall come is, I think, that the belief in miracle was relative to the age in which the miracles occurred, that it was an inevitable product of the culture and ideas of that age, that historically it served the purpose that it was intended to serve, but that it has come down to us with a different mental context, under different conditions, and so requires some corresponding modification of statement. There is nothing strange in all this. It is the way in which God has really ordered the suc- 
cessive ages of mankind, each with characteristics of its own, and each leading on to the next beyond.

It is true that all that I have just been saying has reference specially to a particular class of miracle, to the miracles contained in a particular document or section of the narrative of the Acts. It is a further question how far this can be taken as typical of the rest of the New Testament. I believe that the miracles with which we have been dealing can be taken as typical of another important class, viz. those alluded to in the Epistles of St. Paul. The evidence for these is as decisive as it is for those of the Traveldiary. The events assuredly happened; they were assuredly believed to be miracles, and they assuredly discharged the functions of miracle. But at the same time, they are not described with the same amount of detail. And there is a certain exercise of faith in the assumption that, if they had been described with equal detail, they would have proved to be equally tractable. There is an element of conjecture in assuming this, but I do not think more than is reasonable. What we read about miracles-especially about the charismatain the Epistles of St. Paul is of the nature of things unusual, obedient to laws that are somewhat recondite, distinctly implying divine impulse and divine gruidance, and yet at most non contra naturam sed contra quam est nota natura.

Let me confess at once frankly, that we cannot go quite as far as this in regard to the Miracles of the Gospels. If we take the accounts of these that have come down to us as they stand, we should have to 
assume a degree of interference with the order of nature that is greater in degree and more difficult in kind.

The whole problem before us, as I began by saying, is one of making both ends meet. And it is here in the Gospels that this problem becomes most acute. We cannot as yet make both ends meet; we cannot as yet reach hands across the chasm. But we can perhaps see how the two ends may conceivably meet, and how the chasm may conceivably be crossed some day.

Hitherto our inquiry has run upon double lineson the one hand upon the historical or historico-critical line, of looking carefully at the evidence and trying to estimate its precise value, and on the other hand upon the more or less philosophical line, of looking at the causes or factors with which we have to operate, or which we may assume to have been at work. If any advance has been made, it has been advance upon these double lines, bringing them nearer to each other.

And so in regard to the Gospels, we have first to remark, that we have much that stands high, but nothing that stands quite so high as the Travel-diary of the Acts or the Epistles of St. Paul. Both these authorities are strictly and in the fullest sense at first hand. In the case of the diary, we might even believe that it was not written entirely from memory, but that actual notes may have been set down at the time. Harnack believes that this may have been done (p. 38 ). But however that may be, the distinctive feature of the diary is its peculiar freshness of impression. There is nothing quite equal to this-or at least quite equal for 
our present purpose-in the Gospels. The Gospel of St. Mark, which is the real foundation of the synoptic narrative, is not a first-hand work but a work at second-hand--though I fully believe, good second-hand. St. Mark, if he had actually seen anything, had seen very little of what he describes; he is dependent upon others. I believe myself that the author of the Fourth Gospel was an eyewitness; and, if he was an eye-witness, that is a fact of no small importance in its bearing upon miracle. But, even if it were so, we must remember that an interval of from fifty to sixty years had passed between the events and the time at which he wrote. During all those many years he must have heard his own stories told by others besides himself; they might easily have received slight accretions, which he could not well distinguish from the original facts of his own consciousness. He was also in any case a writer of vivid imagination. We may add, not only so, but a writer with imagination stimulated in this particular direction. St. John held most tenaciously to the belief that he had found the Way, the Truth, and the Life. He believed that the Naster whom he loved was none other than God. Would it be strange if that belief, held so intensely, had affected somewhat his story of miracles, to the extent of heightening some of their details? The possibility is one that I do not think we can exclude. The intellectual habit of the evangelist, though truthful, was believing rather than critical.

I am prepared therefore to believe that there may be 
some deduction to be made, on historical grounds, from the narratives of Miracle in the Gospels. But against this deduction on the one side is to be set a certain enhancement on the other. When we look at the rationale of miracle, the main part of the secret must lie within the bounds of personality, of character and will. Those who worked miracles were without doubt gifted persons; they were persons endowed with special gifts for the carrying out of a special purpose. Now we are prepared to think - and modern experience must make us more and more prepared to think-that the latent powers of personality and human will are very great and very elastic-great and elastic beyond the measure of ordinary experience. Faith-healing, for instance, and Christian Science, whatever we may think of them in other ways, have shown themselves at times capable of producing results that before the fact would hardly have seemed credible. But, if we may argue upward from such things to St. Luke and St. Paul, still more may we argue upward from St. Luke and St. Paul to Him whom they served. From His Person, if from any, we are sure that there went forth healing and power.

In our own day we have seen things, of which if our grandfathers had been told, they would have laughed in our faces. It has become an everyday occurrence for ships on the high seas to communicate with each other and with the land at great distances, for two persons to converse far away from each other, for momentary sounds to be caught and preserved and reproduced at will, for the interior of the human frame 
to be explored and the skeleton seen of the living man. All these things are matters of set contrivance, and miracles were not contrived. But contrivance is only the conscious application of known laws; and the instances I have given will show that laws of which the world is ignorant to-day may be quite familiar to-morrow, and through these laws forces may work the very existence of which is not suspected. All is certainly not irregular that seems irregular. Portentum fit non contra naturam, sed contra quam est nota natura. Deduct something perhaps from the historical statement of the fact; and add something to our conception of what is possible in the course of nature; and if the two ends do not exactly meet, we may yet see that they are not very far from meeting. The question is mainly one of adjustment.

A distinction is often drawn between miracles wrought upon conscious beings and acting (it may be presumed) through their consciousness, and others that are alleged to have been wrought upon inanimate nature. There is doubtless a real significance in this distinction. We must, however, admit that it certainly was not present to the mind of the Biblical historians, and that miracles of the one class are not inferior in attestation to those of the other. This latter class of miracles constitutes perhaps one of the obscurest corners of the subject; but there is one text at least which seems to make it clear that our Lord Himself was conscious of the power of acting upon inanimate things as well as upon men-and, not only so, but that He assumed the existence of the same power in $\mathrm{His}$ 
disciples as well as in Himself. The text is couched in a form of solemn asseveration: "Verily I say unto you, If ye have faith as a grain of mustard seed, ye shall say unto this mountain, Remove hence to yonder place; and it shall remove; and nothing shall be impossible unto you' (Matt. xvii. 20, cf. Luke xvii. 6). This is perhaps hyperbole; for our Lord did use hyperbole-He did not shrink from strong expressions ; but hyperbole implies a heightening of degree but not a difference in kind. We shall therefore keep an open door on this side also, though because some miracles may vindicate for themselves a place within it, it does not follow that all will do so. It is in this direction that we shall probably have to leave some parts of the Gospel narrative unexplained. There will perhaps always be a residuum that baffles explanation; we must be content if that residuum is brought within narrower limits.

The point that perhaps chiefly comes out in such an examination as we have been attempting, is the infinite play and gradation, the subtle correlation of external evidence and internal criticism, over the whole field of Miracle.

In face of the evidence that has been laid before you, how futile and how wrong by every authentic standard of truth and error are the sweeping denials that one often reads and hears. Such denials are of course the easiest thing in the world; but they do violence to history; they do violence to the sensitive conscience of the trained historian. We remember the airy way in which Matthew Arnold used to say 
'Miracles do not happen'. There was more excuse for him then, at the first stage of a really fresh and frank examination of the question in a modern spirit, than there would be for us with a quarter of a century more of reflection and study behind us. But all that he was really justified in saying was that miracles do not happen now. And the truth in this proposition is only, that our attention is fixed upon a different order of causation, and when miracles happen we call them by another name. There are many things, especially in the region of spiritual experience, that might be called miracles, if we cared to use the word. But nothing in modern experience can cancel the wellattested facts of history. That miracles happened in the full conviction and belief of the early Christians, and with the full significance that they attached to miracles, is as certain as our own existence. The only question that is open to discussion is the more exact analysis of the sense in which we at the present day are to describe them as miracles. But we too look back upon them primarily as events in the past. And therefore, for us too, this exact and scrupulous analysis of our own ideas is really of secondary importance. The first thing that we have to grasp is the place of Miracle in the procession of the ages, as they are slowly unrolled in accordance with the mind and purpose of Almighty God. 



\section{THE HIGHER SIGNIFICANCE}

OF THE PERSON AND WORK OF CHRIST

IX. 'ATONEMENT AND PERSONALITY'

$\mathrm{X}$. 'THE GOSPEL, IN THE GOSPELS'

XI. 'THE GOSPEL ACCORDING TO ST. PAUL' 



\section{IX}

'ATONEMENT AND PERSONALity' 1

Dr. Moberly's book is little less than a complete system of theology: It deals with such fundamental questions, and the way in which it deals with them is itself so fundamental and so far-reaching that, either directly or by logical consequence, all the great doctrines of our faith seem to be involved. It is long indeed since a book appeared which gave the same impression of a whole series of connected problems.nct only handled thoughtfully but really thought out, traced back to their deepest roots and followed through to the very end.

And then the reasoned system thus constructed is so firmly knit together, its logical cohesion is so admirable, that it claims-and reasonably claims-to be accepted as a whole.

It is just this inner cohesion that increases the difficulty of those who come to the book more or less from without, with a different set of ideas in their minds and with something which, however inferior, is yet of the nature of a system of their own. They will not find it so easy as they do with most books to

${ }^{1}$ Atenement and Personality. By R. C. Moberly, I.D. London, 1901. There is a cheap edition now to be had $(1907)$. 
accept and assimilate a point here and a point there. What they have before them presents itself as a complete recasting-or perhaps more correctly a complete re-interpretation - of their whole creed. It will seem to the reader at times as though this re-interpretation had to be either taken or left as it stands, and could not be partly taken and partly left. The present paper is an attempt, which the writer thinks will have to be made by others besides himself, to see how far any such separation of parts is possible.

Before going further let us add to the description by saying that the style in which the book is written reflects the qualities of the thought. The book is executed, as it is conceived, in the 'grand style'. The very construction of the paragraphs is such as befits a great book and not a small one. Perhaps there is just a little redundance of illustration and exposition. We are sometimes tempted to ask whether, when a thing has been said as well as it can possibly be said in words of one syllable, it is quite necessary to repeat it or to repeat it more than once in words a good deal longer. But the important thing is that style and thought together are to an extraordinary degree consecutive, clear-cut, exact. If the reader experiences any difficulty we may be sure that it never arises from real vagueness or haziness or superficiality. Dr. Moberly emphatically knows his own mind, and it will be the reader's fault if he also does not know it. At the same time, though keenly logical, the book is the very reverse of dry and hard. It glows with intense conviction, with the inspiration of a lofty ideal; and yet the glow is subdued 
by the consciousness of dealing with the most sacred themes.

In short, the book is one of such high distinction both in matter and form that I should hesitate to say what I really think about it or to assign to it the place in English theology that I believe it really holds. I may perhaps do so before I conclude.

It should be said further that every possible help is given to the reader. There is a motto in Greek (Gal. vi. I4). There is a cledication, which is really a summing up in brief of the central thought of the book. There follows an analysis of the contents which is remarkably full and able. And to complete the whole there is an excellent index. Seldom has a book been set before the public in which so much was done to make the course of the argument clear and intelligible. And seldom has an argument been so commended by gravitas, airnitas, pietas, reverentia.

\section{I}

I said that the dedication contains the gist of the whole volume. It is as follows: To | tuE CHurcu| One Holy Catholic/ the Body of the Spirit | of Jesus Christ | very God of very God | Incarnate | which is / the Regeneration and Hope $\mid$ of the WHOLE: WORLD.

It may surprise some readers to see that there is not a word here that suggests what they are in the habit of associating with Atonement; and it may be well to say at once that Atonement is to be taken throughout in the largest sense. It is not a part of what we some- 
times call 'the scheme or process of redemption', but the whole of it. I shall presently ask whether a certain portion of the process is not emphasized rather too exclusively, whether it is not made rather too much to absorb the rest. But in the meantime the terms of the dedication will explain what I meant at the outset when I said that the book touched in turn upon all the most fundamental doctrines of Christianity. It deals at very close quarters with the whole question of the Incarnation. It deals at equally close quarters with the whole doctrine of the 'Trinity. Its leading thought is an exposition of the nature and work of the Holy Spirit.

I do not know what will be the feeling of others, but I confess that to me the treatment of all this side of the subject is extraordinarily helpful and attractive. It happens that I have myself for some time past been engaged more particularly with these topics. And not only do I constantly find Dr. Moberly suggesting the very word or formula that I want, but I should also say that, as well as I can judge, the whole of my experience and reading goes to confirm his conclusions. I certainly do not know any other book on these subjects which approaches this in value. It is bold with the boldness that comes when a thing has been really thought out; and the boldness is never, to the best of my belief, otherwise than justified.

I should like to quote and to quote freely; but I must content myself with setting down a few heads on which I would refer the reader to the book itself.

The doctrine of the Trinity is essentially a doctrine of Trinity in Unity. The basal truth is that God is 
one. The further revelation of Divine 'Persons' explains and expands but does not contradict this. 'The personal distinction in Godhead is a distinction within, and of, unity: not a distinction which qualifies unity, or usurps the place of it, or destroys it ' (pp. xxiii, $8_{3}$, I 54 f., 202).

The popular theology verges dangerously upon Tritheism. The word 'person' is the best that can be used. And yet in using it we ought to lay stress rather on its positive than on its negative side. We must guard against being misled by our own experience of personality. We should think of the Divine Persons as 'mutually inclusive' rather than 'mutually exclusive' (pp. xxiii, I 56-63, 202).

The safeguard against Sabellianism lies in the word 'mutual'. The relations of the Divine Persons to each other are inutual relations. But Sabellianism ' clegrades the Persons of Deity into aspects'; and 'there can be no mutual relations between aspects' (pp. So, I 65).

Christ is God, not generically but identically. For the word God does not admit of a plural. And Christ is also Man, not generically but inclusively. He is not one man amongst many. The nearest analogy for $\mathrm{His}$ relation to mankind is that of Adam; and even that analogy is imperfect. His Humanity 'was not merely' the Humanity of a finite creature, but the Humanity of the Infinite God'. It had therefore a unique capacity for universal relation. And the means whereby that universal relation is realized is His Spirit (pp. $\mathrm{xx}, 88 \mathrm{f}$, 204). [This of course is difficult; but the difficulty is one that the Christian theologian cannot escape; 
and I know no treatment of it that is so helpful as Dr. Moberly's.]

In our insistence upon the Two Natures in Christ we are in danger of falling into Nestorian dualism. "The phrase "God and man" is of course perfectly true. But it is easy to lay undue emphasis on the "and". And when this is done-as it is done every day-the truth is better explained by varying the phrase. "He is not two, but one, Christ." He is, then, not so much God and man as God in, and through, and as, man.' It is a mistake to try to keep open, 'as it were, a sort of non-human sphere, or aspect, of the Incarnation' (pp. xx, 96 f. ; cf. 94).

The dominant idea in the minds of the New Testament writers is that of the Incarnation. The revelation both of the 'Son' and of the 'Spirit' has reference to this and grows out of it. The title 'Son' is given to our Lord in the New Testament primarily as the Incarnate. To say this is not to imply that the terms 'Father' and 'Son' have not a further truth in regard to the eternal relations of the Godhead; but the order in which they are revealed arises out of the Incarnation (pp. xxiv, I 84 ff.).

Hence the many passages, especially the salutations of the Epistles, in which Two of the Divine Persons appear to be mentioned without the Third, are by no means a 'maimed Trinitarian formula'. They contain no direct reference to the Trinity. The primary reference is rather to the Incarnation-to God as Eternal and God as Incarnate. But really the Third Person, though not mentioned, is implied. It is through the 
Holy Spirit that 'grace and peace' come from God to us (pp. xxiv, I 87-95).

I very much wish that space allowed me to develop these points as they deserve. But I have much yet to say; and I very much hope that the reader who seeks enlightenment on these deep mysteries will seek it, not in these pages, but in those of the book itself. The references have been given partly to indicate where help may be had on subjects that are naturally difficult and abstruse, and partly to illustrate the wealth of valuable matter that surrounds the main course of the argument.

\section{II}

But it is time to set out more directly what that argument is.

It starts from an analysis of the connected ideas of punishment, penitence, forgiveness. The main object of such punishment as comes within the range of Atonement is to produce penitence. It is penitence that really atones. Forgiveness is the correlative of 'forgiveableness'. It is not simply not punishing; or treating as if innocent, or regarding as innocent. These things are not even moral apart from a justifying cause. The justification is to be sought in penitence, which is a real change of self wrought from within.

Real penitence-not only the perfection but any adequate degree of penitence-is to simple human nature impossible. Perfect penitence requires not only contrition for sin, but complete identity of the self with the holiness which condemns sin. This combination 
is to be found only in Christ, whose death upon the cross was as it were a vicarious penitence perfect in its kind.

The great question is, How is this transcendent act of penitence on the part of Christ to be brought home to the human soul? And the answer is, Through the operation of the Holy Spirit transforming the human self from within; making the objective subjective; renewing our nature, so that it is no longer ours but Christ's, not by the destruction of our own personality but by its consummation. Pentecost is the true complement of Calvary. Calvary without Pentecost is not yet in vital relation with ourselves. Its virtue becomes ours through the indwelling Spirit of Christ.

These are the main lines of the argument, very imperfectly sketched. I will assume that most of those who read this will obtain a closer acquaintance with it. The hints that have been given may be enough to hang our comments upon; and they may in what follows receive some extension.

The points on which I propose to comment more particularly are three-(1) the conception of forgiveness as necessarily implying 'forgiveableness'; (2) the mode in which the transition from objective to subjective is effected, as involving the denial of anything in the nature of a 'transaction'; (3) the view of the indwelling Spirit as ultimately constituting the true self.

Now it is to be observed that on each of these central points Dr. Moberly's treatment is in the fullest possible accord with the tendencies of modern thought. 


\section{IX. 'Atonement and Personality'}

Like him, modern thought also denies that forgiveness can be separated from forgiveableness. Like him, it repudiates any idea of a 'transaction'. Like him, not quite so broadly, but yet in an active section of its representatives, it is prepared to break down the distinctness of the individual. And over and above all this it must needs welcome the bringing of so large a part of the spiritual world under the dominion of rigorous and unchangeable laws.

This relation of Dr. Moberly's book to modern thought is, I need not say, a very important matter. It shears away at one stroke a whole forest of objections to Christianity. It supplies a theory in which many of the most cultivated minds may well be content to rest. It justifies the ways of God to men on a scale to which it would not be easy to find a parallel.

I am well aware of this; and I am also well aware that the questions which I am about to raise and the criticisms which I am about to offer are not at all likely to meet with so favourable a reception in these quarters. I cannot say that I feel this to be wholly a misfortune. I have no wish to challenge the theory for those who desire to accept it. All I wish to do is to vindicate a place for another and older theory and to throw a shield, if I may, over those who cannot readily persuade themselves to part with it. It seems to me that this is just a case where the Christian Church should recognize alternative views as tenable. ${ }^{\text {? }}$

${ }^{1}$ [This is faultily expressed. The view's are not alternatives: see below, pp. 288,300 f.] 


\section{III}

The first question that I should have to ask would be whether we can expect to make good a theodicy on so vast a scale. A theory such as that which is propounded to us seems almost to eliminate mystery from a large part, and that one of the most profound parts, of the dealings of God with men. I should not object to the theory if it took the form of one possible explanation of those dealings. What I stumble at is the negatives by which it is accompanied. I mean the strong assertions which meet us from time to time that such and such a thing cannot be.

I fall back upon Butler's Analogy. We live under a scheme of things imperfectly comprehended. We live under a scheme of things which contains many features that are different from what we should expect them to be. The one fact of the presence of evil in the world throws out many of our calculations; and perhaps it ought to throw out more than we suppose.

I have the greatest reluctance, even upon what seem to be obvious propositions of morality, to lay down laws for the Almighty. 'Shall not the Judge of all the earth do right ?' is no doubt an axiom that stands absolutely fast. But it is another thing to say that we shall always be able to see what is right. The lines meet no doubt somewhere, but that meeting-point may be beyond our ken. It is well for us that it should be so. It is well that we should walk sometimes by faith and not by sight. It is well that we should feel that we are

'moving about in worlds not realized'. 
I shall have occasion perhaps more than once to fall back upon this principle. But the necessity does not trouble me. It is one of those for which I am antecedently prepared.

I can go with Dr. Moberly when he says that 'remission of penalty must have a justification' (p. $5 \mathrm{I}$ ); but not if he means, as he seems to mean, a visible tangible definable justification. He seems to me to pursue this idea to the point of making forgiveness cease to be forgiveness in the sense that I should attach to the word. I must needs associate myself with his own admirable statement of the objection to his view, the substance of which was already in my mind before I reached it.

But when we venture to give to the word forgiveness any meaning of this character at all, we are met, no doubt, by one or two very real difficulties of thought. Thus the question suggests itself, if forgiveness (with whatever provisoes) is made to be simply correlative to forgiveableness ; and if to say that a man is forgiveable means not merely that he may be, but therefore ipso facto that he ought to be, nay, must be forgiven; if forgiveness, that is, is a sort of automatic and necessary consequence of a certain condition of the culprit's personality; are you not exactly taking out of forgiveness all that it ever had distinctively meant? Are you not precisely and completely explaining it away? When you say you forgive, you are merely recognizing the growth towards righteousness of those who are already becoming righteous. You may call it forgiving only those who deserve to be forgiven. Is it really more than this, that you acknowledge the goodness of the good; or, at all events, the imperfect goodness of the incompletely good? You merely do 
not continue to condemn those who no longer ought to be condemned? So far as they are still wicked, you refuse to forgive them. So far as they are becoming righteous, they do not need any act of yours to forgive them. In other words, there is no place left for forgiveness. Either, in accordance with truth, you still condemn, or else, in accordance with truth, you acquit and accept. Where does forgiveness come in ? Justice this may be. But has not forgiveness, as forgiveness, dropped out altogether? Either there is nothing that can be called forgiveness at all; or, if there is, it is a forgiveness which can be said to have been, by deserving, 'earned': and is not forgiveness that is earned exactly not forgiveness? (pp. $5^{8 \mathrm{f}}$ )

I waive the point to which Dr. Moberly demurs about 'earning' and 'desert'. I gladly acknowledge that later in the book (e. g. pp. 3 I 9 f., 32 I f.; cf. I 39 f.) he repeatedly lays stress upon the fact that the preparation for forgiveness is not the work of the sinner himself. But I do not think that he ever adequately answers the objection that forgiveness as he defines it is neither what is commonly meant by the word nor what is often meant by it in the Bible. It seems to me also that forgiveness is not the only word that does not come by its due. 'Mercy' I should be inclined to say was another, and other words of a like kind.

Take for instance those familiar lines of Shakespeare's-

\section{Whereto serves mercy,}

But to confront the visage of offence?

And what's in prayer, but this twofold force-

To be forestalled ere we come to fall,

Or pardoned, being down?

And again- 
But mercy is above this sceptre'd sway, It is enthroned in the heart of kings;

It is an attribute to God Himself:

And earthly power doth then show likest God's When mercy seasons justice.

I do not doubt that in such contexts as these Shakespeare as usual speaks for the popular mind. I do not doubt that in the myriads of cases in which 'mercy' and 'forgiveness' are ascribed to God the great mass of mankind understand by them simple remission of penalty, without regard to the cause of the remission.

And I should have equally little hesitation in asserting that there are numbers of places in which the Bible, New Testament as well as Old, does the same thing. The very word 'forgiveness', I imagine, has this meaning. I should not be surprised if it were maintained that the word $\pi \dot{\alpha} \rho \in \sigma i s$ means something provisional or conditional. But that is just what I conceive distinguishes it from its synonym ă $\phi \epsilon \sigma \iota s$. And if we seek for explicit statements, what can be more explicit than Rom. iii. 24: 'Being justified freely by His grace through the redemption that is in Christ Jesus'

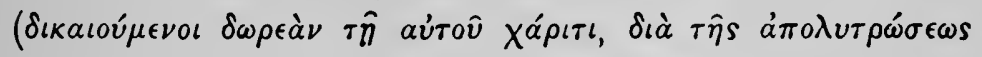
$\tau \hat{\eta} s \dot{\epsilon}^{\prime} \nu X_{\rho \iota \sigma \tau \hat{\varphi}}$ 'I $\left.\eta \sigma \sigma o \hat{v}\right)$, where the Greek is even more significant than the English? To reconcile this with Dr. Moberly's view, should we not have to blot out $\delta \omega \rho \epsilon a ́ \nu$ altogether and to take away half its meaning

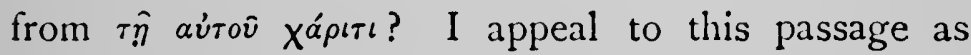
perhaps the one most directly in point, though there are many others that seem with different degrees of directness to imply the same thing. Such would be 
(e. g.) Eph. ii. 4-6; Titus iii. 4-5; Rom. v. 6-1 I ; Matt. xviii. $23-35$ (the Unmerciful Servant); Luke xv. I-7, 8-I o.

I do not deny that some of these passages, especially those from Ephesians and Titus, do not stop at the moment of forgiveness, do not leave the sinner at the point where he is 'dead in trespasses', but go on to speak in the one case of quickening or raising up with Christ, and in the other of the renewing of the Holy Ghost. I do not deny that we may also, if we please, take up the position that the Divine forgiveness always has in view these further stages of Christian life. But it seems to me that if we follow the tenor of Scriptural teaching simply, without letting ourselves be disturbed and diverted by considerations from without, we shall see (i) that the Christian life does consist of a series of successive stages; and (ii) that the Scripture does not hesitate to speak of the initial stage by itself and without reference to the later stages. I conceive that most of the places where St. Paul uses the verb 'to justify'

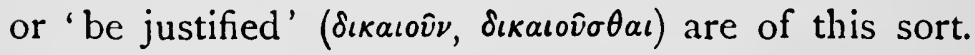
I cannot quite go with Dr. Moberly's note on this word (p. $335 \mathrm{f}$ ). I believe that in all these places it has strictly the sense that belongs to it in common usage, and that this, and no other, entirely suits the contexts.

I think therefore that much of our popular theology -the theology of street preachers and evangelistshas really a great amount of Scriptural support behind it when it lays stress upon a 'free forgiveness'. I do not think that it is wrong in the order in which it 
presents its message-Forgiveness first, and love and obedience flowing from forgiveness. Not that this is the only order or that the links in the chain can be ever really separated, but that this is distinctly an order in which the Scripture itself presents the sequence, and that it has been found in practice to possess a great power of attraction.

For, further, it seems to me that this order appeals to an instinct that is really planted deep clown in our nature. There are different types of forgiveness. That on which Dr. Moberly insists might be called the 'parental', or ' paedagogic' type. And if it is contended that that is the type most nearly analogous to Divine forgiveness, I should have nothing to say to the contrary. But the human heart is instinctively drawn to another form of forgiveness that has in it (as we should say) no arrière pensée, no element of calculation, but which is simply the pure outflowing of love; ignoring misdeeds, forgetting the past, and simply going forth to meet and embrace the offending and alienated friend. A love such as this asks no questions and makes no conditions. It is not thinking either of conditions or of consequences. The rush of its own inner strength carries it forward. If it is rebuffed, it takes its rebuff meekly. It sinks back perhaps bruised and wounded but in no way repenting of its venture. And if it succeeds the success is glorious-just the kind of success to make the very angels in heaven rejoice.

Are we to think that there is nothing corresponding to this, with whatever unseen and unimagined modifications, in God? Is it only a product of human 
short-sightedness and imperfection? If we are ob!iged to say that it is, would not that mean that one of the purest and most disinterested feelings in man had no counterpart above itself? Should we not at last have found something which the Great King Himself may not enjoy, though His subjects may? And would not that one thing be, no counterfeit, but the real distilled essence of forgiveness?

\section{IV}

The next great issue that separates me from Dr. Moberly, without doubt a greater than the last, on which I know that I have made and feel that I ought to make so many concessions that the difference between us (except just on the point of the paragraphs immediately preceding this) might be regarded as almost formal; the next, and not only greater but really greatest issue, is as to whether the atoning death of Christ can be described as in any sense a 'transaction'. Here again, and here most profoundly, I am aware that my friend has on his side an immense weight of cultured and highly trained opinion. I cannot be sorry that he should speak to so large a public in tones that it will recognize as its own. The only thing for which I confess that I am a little sorry is that in speaking of the 'transactional' theory he should have thought it necessary to set it in the pillory, not only in its extreme forms but in a travesty even of them. I have in mind more particularly a sentence on p. 342, which recalls to me rather by way of contrast another sentence on p. xi of the Preface as to certain 'infer- 


\section{IX. 'Atonement and Personality'}

ential structures - - it is the same structures that are intended-' the most untrue of which has considerable relation to truth.' Abusus non tollit usum. Nobody in these days believes in the more monstrous developments of the past. To denounce them is like slaying the slain. We do not need these awful examples. If we were not ourselves sensitive enough in regard to them, outsicle opinion would warn us off such ground. It is an altogether happier function to seek out the grain of truth that lies hid within the error, to set that in just proportion.

It is of course also a misfortune that we should have to use these terms 'transaction', 'transactional', which carry with them in the context a shade of meaning that is naturally repellent. It is not really this side that we wish to put forward. What we mean is that among the mysteries that surround the Atonement (and no one is more conscious of these than Dr. Moberly) there is one great field of mystery, with which we ourselves are only concerned through its effects and which we cannot explain but must not explain away.

Our reasons for believing in the existence of this particular field of mystery are partly because we think that it is revealed, partly because the assumption that it does exist seems to us to supply a key to many things in the history of the race which we could not understand without it; partly also because by the application of the historical method it appears that the antecedents of apostolic thought would naturally point in this direction. 
I remarked some way back on the rather curious fact that the dedication of Dr. Moberly's book, which in a manner summarizes the leading thought of the whole, does not contain a single one of the terms that some of us are most in the habit of associating with the Atonement. It will seem to these that his treatment of the Scriptural basis of the doctrine is strangely unequal. Some of the passages involved have the fullest possible justice done to them. They are set in a new light and are brought home to the mind in a very striking manner. But others which appear to be hardly less relevant are either not introduced at all or introduced only in a brief section in smaller print that comes in parenthetically in the last Supplementary Chapter on the 'Atonement in History'. In this section there is a rapid survey, which is no doubt very pertinent, of a number of New Testament passages bearing upon the doctrine.

Of course every writer must follow his own bent and treat his subject in the way that is most natural to him. It is no valid criticism that others would have treated it differently. Still the fact remains that we have stowed away in this small corner what for many of us would have had a place in the main thesis of the book; and I cannot help thinking that these parts of the subject are really minimized.

It may be true that the variety of the metaphors used in Scripture goes to show that none of them can be pressed to their full logical extent. But so many of these converge upon the one idea of sacrifice that it seems as though we were obliged to accept this idea 


\section{IX. 'Atonement and Personality'}

as quite central and essential to the whole conception of Atonement.

Now, far be it from me to say that Dr. Moberly does not recognize this aspect of the Atonement as a sacrifice; but he seems to me to throw quite into the background certain features which in the writings of St. Paul and St. Peter and St. John and the Epistle to the Hebrews are not in the background, but prominent and even central.

One gronp of terms in particular to which I cannot find that justice is done is the group that we translate

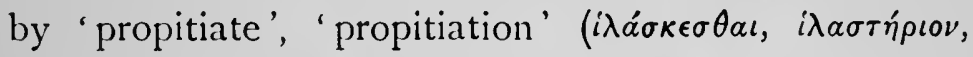

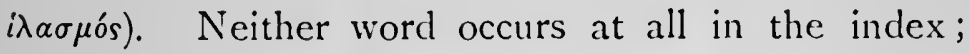
there is only an incidental reference to the group on p. 334 .

Another group of the same kind is that which includes 'blood-shedding', 'sprinkling of the blood,' and the phrase 'in the blood'; the underlying principle of which is laid down in Hebrews ix. 22, 'Apart from shedding of blood there is no remission.'

I am well aware that modern thought has a short and easy method with all these terms. If it is compelled to give an account of them it sets them down as relics of primitive barbarism. But more often it simply ignores them and goes on its way without them.

Dr. Moberly does not altogether do this, but he comes rather near doing it. Sacrifice is with him the expression of certain moral ideas, and he tries to treat it as though its significance were exhausted by those ideas.

I need hardly say that I sympathize with the effort, 
which is the better side of the movement of thought that we see around us. But those of us who start, not from any philosophical or theological system but in the first instance from the Bible, cannot wholly satisfy themselves with this method. It may be an open question, as it is no doubt a further question, how the Biblical teaching is related to their own ultimate personal beliefs. But before they come to that point they must resolutely make up their minds not at any cost to tamper with the facts as they see them. Whether they like or dislike, whether they understand or do not understand, their duty is the same. Neither ignorance nor knowledge, neither sympathies nor antipathies, neither the attractiveness of one theory nor their repugnance to another, not even the highest or purest of moral instincts and aspirations, must be allowed to divert them from the straight path. They are like Balaam before Balak, and what is put into their mouths that they must say, with all its chances of its being wrong, with all its risks of being misunderstood, with all their consciousness that it is but seeing 'through a glass darkly'.

Those then for whom I am speaking must directly face the fact that these terms-'propitiation,' 'bloodshedding ' and the like-have the prominence they have. It is quite another thing to say that they understand them. They are awful words. And when we try to penetrate into their meaning we soon find that we have to bow the head and be silent.

But so much at least seems to follow from them, that the Scriptures do recognize a mysterious some- 
thing which, in our imperfect human language, may be described as a 'transaction'. It seems to me difficult for the plain reader of his Bible to deny this.

But, when we have got so far, abashed and silent as we may be, there seem to open out long vistas which at least give to the history of the human race and to the course of God's providential dealings with men a unity that they would not have otherwise.

I. A new light is thrown on what I have said that modern thought would dismiss as 'primitive barbarism'. This contemptuous estimate is in fact utterly superficial, and not less unscientific, in any true sense of science. Surely the doctrine of Evolution has taught us not to make light of humble beginnings. The first beginnings of sacrifice may be humble and the ideas associated with it may be crude; but we cannot stop short at these. The eye must needs follow it down the ages until it reaches its culmination on Calvary. If we take what I conceive to be the Biblical view of Calvary, then we have a true evolution with a true culmination. The course of things becomes intelligible where before it was not. At least we see that the dim half-conscious gropings of the human mind far back in the past had a diviner goal than we might have supposed.

2. Another subject on which the propitiatory aspect of the Atonement appears to throw light is the value of Vicarious Suffering.

We may join with Dr. Moberly and the moderns in rejecting the idea of Vicarious Punishment, except in so far as this means pain incurred in the necessary working out of the consequences of sin. But whatever 
we may say as to Vicarious Punishment we must not lose our hold on Vicarious Suffering. On Dr. Moberly's theory the form which this takes is mainly as penitence. And perhaps it is true that vicarious penitence, $\mathrm{His}$ utter identification at once with the judgement of God upon $\sin$ and with the heartfelt contrition that man ought to feel but cannot adequately feel for it, was the most poignant of all the pangs of the Divine Sufferer on Calvary. But here again we have a climax, and our thought must include all the pain and all the humiliation that $\mathrm{He}$ underwent in taking upon Himself the nature of man.

It is just in regard to this vicarious suffering that the Old Testament comes in to reinforce the New. No other sacred book has anything like it. And here once more the great example does not stand alone, but is reached through a number of delicately drawn concentric circles of which it is the centre. The Bible is the most consoling book in the world, just because it reveals to us the extreme beauty and value of that untold mass of suffering endured for the sake of others which seems at first sight the greatest flaw upon God's creation. We see at last that this form of suffering belongs fitly to such a world as that in which we live-not to a world serene, untroubled and always in sunshine, certainly not to a lotus-eating existence, to a world that has its sad minor chords, but yet to a world in which

'We feel that we are greater than we know'.

A world like this can have no other centre than Calvary. 


\section{IX. 'Atonement and Personality'}

3. When we look at the Biblical writers historically we see that the elements of this particular conception of the Atonement were already in their minds. They not only inherited the great sacrificial system of the Old Testament, and they not only had before them the profound teaching of the latter part of Isaiah respecting the Servant of Jehovah with the parallel teaching of certain Psalms - scriptures which took the deepest hold of the first generation of Christians-- but in addition to this they in all probability had distinct ideas, if not exactly as to Vicarious Suffering (which was a subject developed in the Talmudical theology somewhat late and under the influence of Christianity), yet at least as to vicarious merit. Some of these ideas needed to bc purified and they were purified; but we can see how they helped to supply material out of which the Christian doctrine was constructed. I am afraid that I cannot recall any contemporary teaching that would in like manner suggest Dr. Moberly's theory of Vicarious Penitence.

\section{V}

We now come to the philosophical question which has caused Dr. Moberly to combine together in his title 'A tonement ' and 'Personality'. In regard to this I desire to keep an open mind, but I must confess to a good deal of hesitation.

Dr. Moberly's point is that Personality, when analysed, is found to consist of Will, Reason, and Love. But in our present state each of these is necessarily imperfect; they only reach their perfection through 
the indwelling Spirit of God. Dr. Moberly goes so far as to say that this indwelling Spirit actually constitutes the renewed and regenerated self.

I think that he guards himself sufficiently against Pantheism, though I could rather wish that he had stated the distinction as explicitly as he has done in the case of Sabellianism earlier in the book. The self is not, as I understand him, merged and lost, but only comes to respond perfectly to the will of God. His view appears to be modelled more especially on two passages in the Epistles of St. Paul. One is 2 Cor. xii. 2-5: 'I know a man in Christ, fourteen years ago (whether in the body, I know not; or whether out of the body, I know not; God knoweth), such a one caught up even to the third heaven. And I know such a man (whether in the body, or apart from the body, I know not; God knoweth), how that he was caught up into Paradise, and heard unspeakable words, which it is not lawful for a man to utter. On behalf of such a one will I glory: but on mine own behalf I will not glory, save in my weaknesses.' On this we have the following remarks- Of whom is St. Paul speaking? There is one before his thought whom he sharply contrasts with himself$\dot{v} \pi \grave{e} \rho \delta \dot{\epsilon}$ é $\mu a v \tau o \hat{v}$ ov. Who is it ? Who is the 'self' of whom he will not glory and who is the 'such a one' of whom he will? Are they not both-with whatever difference-himself?

Even then the veteran apostle and martyr, who, in vision, by anticipation, had himself seen and tested the truer reality of himself, yet means by 'himself', in the present, the imperfect self, the self characterized by weaknesses within and distresses without, and chastened 
by the 'thorn in the flesh', the messenger of Satan to buffet him.

As the clear vision of his transfigured self does not prevent his self-identification meanwhile with the weakness and distress; so does not his true self-identification with the weakness and distress obscure the truth that the transfigured being whom, having once felt, he cannot but contrast with himself, yet is, to say the least, something very far nearer than he is to the true and ultimate reality of himself (p. 320 note).

The other passage is Gal. ii. 2o. Of this Dr. Moberly writes-

If any one desires a Christian formula for the central conception of human personality, it may be gathered from the words of St. Paul, 'I have been crucified with Christ; yet I live; and yet no longer I, but Christ liveth in me.' I, yet not I. Not I, and therefore I, the full, real, consummated 'I' at last. Here is the real inmost principle of life and immortality brought to light by the gospel of Christ (p. 255).

The first passage brings out the continuity of the two selves; the second brings out the identity of the renewed self with Christ.

It will thus be seen that Dr. Moberly has full Biblical support for his theory. And the two passages that have been given are only samples of a number of others. It must be confessed that this is a strong point in its favour.

My hesitation comes in rather from the side of philosophy. I cannot feel sure of the sufficiency of the analysis which resolves the 'person' into will, reason, and love. I desiderate something more-the bond to hold them together. I cannot find that I can 
do without the 'distinct centre of being'. If I interrogate my own consciousness this seems to me the prime fact to which it testifies.

It is no doubt true that this 'centre of being' cannot be wholly isolated from its surroundings. It feeds, so to speak, upon these surroundings, just as the body takes in from without the food that keeps it alive. But as in the body there must be the organs to assimilate the food, so in the self there must be something central to correlate and unify the impressions from without. This constitutes the empirical self, the self of experience-the imperfect self if you will-but there must needs be a centre somewhere to maintain the continuity between the different phases.

This is as far as I can see at present. I am still disposed to try whether the formula of 'influence', which I have hitherto been in the habit of using in these cases, will not best satisfy all the conditions. The influence may be the very closest and most penetrating conceivable; but I am compelled as yet to think of it rather as influence than as absorption or substitution. It seems to me that for this too there is Biblical warrant; e.g. St. John xiv. 23: 'If a man love $\mathrm{Me}$, he will keep $\mathrm{My}$ word: and $\mathrm{My}$ Father will love him, and We will come unto him, and make Our abode with him'; and Rev. iii. 20: 'Behold, I stand at the door and knock: if any man hear My voice and open the door, I will come in to him, and will sup with him, and he with Me.' In such passages the reciprocity between the human self and the Divine Presence is fully maintained. As at 


\section{IX. 'Atonement and Personality'}

present advised I should be disposed to explain the other passages in the light of these. By so doing we can keep in closer touch with mother earth and those realities of which we have the most immediate cogni. zance. [See, however, p. 309.]

\section{VI}

If I am, in conclusion, to try to form an estimate of the book as a whole, my first feeling must be one of regret that it should be unfortunate in its reviewer. Great as it undoubtedly is, and great as he feels it to be, it yet collides with too many of his own cherished ideas for him to be able to do it complete justice. It is true that the accessories alone are so replete with interest and instruction that, even if there was nothing in the main argument with which he could agree, he would still have a book that he could prize most highly. But there is of course much more than that. Even a reviewer whose mind is somewhat pre-occupied cannot help being impressed by the elevated character of the whole conception. It is, as was hinted at the outset, a really heroic attempt to construct a far-reaching theodicy of a large part of God's ways; and it is an attempt that has all the inner marks of success that belong to a singularly well-articulated and wellcompacted structure.

As the eye travels backwards over the course of English theology in search of a work of the same kind (i. e. in the department of philosophical theology) and of equal magnitude it seems to find nothing to stop at until it comes to Butler's Analogy. But then this book 
stands to the Analogy not so much in the relation of a supplement or development as of an alternative. The Analogy is based upon a profound sense of the mystery of things, but the mystery is evenly distributed. Whichever way the mind looks it is met by mystery, and the resultant attitude is like that of the Psalmist when he says, "I refrain my soul and keep it low.'

But with Dr. Moberly's book the case is different. There the mystery recedes to an unexpected degree from a part, and yet only from a part, of God's ways. One section of them as it were is thrown into bright light, the effect of which however is but to increase the surrounding shade.

And in relation to the Scriptures the effect seems to be similar. It is one of the strong points of the book, and a point by which I am duly impressed, that it gives the fullest possible force to certain of the Apostolic and even of the Evangelic utterances. But then there are others of which this cannot be said. Rather, the theory by its negations seems to stand in the way of adequate justice being done to them.

These negations indeed are not peculiar, they are common to much of the more advanced thought of our time. We who cannot share them are yet very far from grudging the help that is given to those who can. We are only compelled reluctantly to keep to old paths as best we may. 


\section{$\mathrm{X}$}

'THE GOSPEL IN THE GOSPELS'I

From time to time alumni of the University of the South find their way to Oxford. And I have noticed about them, that they speak with even more than the usual veneration of their University and of its home at Sewanee in the State of 'Tennessee-planted on a high plateau more than 2,000 feet above the sea and breaking downwards in picturesque ravines and gullies. The University has no millionaire behind it, like so many of the great institutions of the Western Republic. To all appearance ruined soon after its foundation by the Civil War, and a gradual growth from small beginnings, it yields to none of its wealthier and more imposing competitors in the affectionate reverence of its sons. Indeed there has always seemed to me to be a peculiar quality about this reverence, such as we, on this side the Atlantic, are accustomed to see in those poorer bodies that have about them some special touch of romance.

Sewanee to its votaries is a kind of Mecca, and it has its prophet-a living prophet-in Dr. W. P. Du

1 The Gospel in the Gospels. By W. P. Du Bose, S.T.D., Professor of Exegesis in the University of the South (U.S.A.). London and New York, 1906. 
Bose, the Dean of its Theological Faculty, who is a real sage and seer.

I had the privilege of meeting Dr. Du Bose-not for the first time, for we had made acquaintance some ten or eleven years before in Oxford-under the hospitable roof of the Editor of The Churchman. We had several strolls together along the lovely shores of Long Island; and I found in him a seer of the cultivated, quiet, homely kind, not without the charm of that selfforgetfulness which is permitted to thinkers, and with absolute singleness of aim. Dr. Du Bose, as might be inferred from his name, is of French extraction. $\mathrm{He}$ told me that in a long line of ancestry there was only one British name-that of a Scottish Sinclair. And yet in spite of this descent, he said, 'I'm English all over.' Needless to add, we struck an alliance on the spot. Dr. Du Bose's ancestry had been loyalists in the War of Independence. He himself, as a young man, had fought in the ranks of the Confederates, had been badly wounded and taken prisoner, and reported dead, and had then taken an active and devoted part both in the literal and in the moral rebuilding of Sewanee.

There were all the materials here for casting a horoscope; and in addition, I had-and ought to have had still more-the advantage afforded by earlier works, The Soteriology of the New Teslament (1892), and The Ecumenical Councils (2nd edition, I897); and yet I do not think that I quite expected all that I find in this new book, The Gospel in the Gospels. 


\section{$X$. 'The Gospel in the Gospels'}

I will say what is in my mind at once: it is just the kind of book that English-speaking Christianity is wanting! The world is always in want of a prophetwe at this moment are specially in want of a prophet -and here is one!

Let me try to describe what the character of the book is.

In the first place, as to style and manner. Curiously enough, as I think over the book, there rise irresistibly to my mind two passages of Wordsworth that may well seem far remote from its subject. One is from the 'Poet's Epitaph ':-

But who is this, with modest looks And clad in homely russet brown? ...

Not that I would suggest any defect of clerical costume; there was no such defect. And if the author is a poet, he is so most unconsciously. There are certainly none of the airs and graces of a poet. That is really the esoteric meaning of the 'russet brown'. The book shows a quite perceptible neglect -I had almost said impatience, if Dr. Du Bose could ever be impatient-of the ordinary little literary conventions. There is hardly a reference all through the book. There are no inverted commas for quotations. Every now and then a sentence reads rather awkwardly ; sometimes it will not construe at all. Dr. Du Bose shares with some of his countrymen a certain readiness in coining new words, about which we on this side the Atlantic should have some scruple: 'reportorial' (pp. 8, I3I), 'immanental' (p. 47), 'righteousing' 
(in the sense of ' making righteous' or 'investing with the character of righteousness', p. I 23).

But we feel, as we read, that these are the merest trivialities, which come quite as much from the total absence of literary vanity as from anything else. Really, the style and matter fit each other admirably. Dr. Du Bose is dealing with lofty, and by no means easy and obvious themes; he is obliged to repeat the same abstract thought many times throughout his book; and yet he never seems in want of an apt and aptly varied expression. There is no real obscurity; if any reader finds any part of the book obscure, the fault is probably in himself; perhaps it is too much to expect that all the world should breathe freely at such altitudes. To clothe in grave and suitable words so much deep thinking is no small achievement. The book bears a stamp of its own, it is one that no one else could have written.

The other Wordsworthian echo that comes to me arises out of the subject-matter and mode of treatment :

When with an eye made quiet by the power Of harmony, and the deep power of joy,

We see into the life of things.

The one slight change that has to be made here is that we must substitute some more sober word for 'joy'. Not that it was possible to write such a book without an inward emotion closely akin to joy. If a note of elation had broken through now and then, no one would have been surprised. It is sheer simplicity, sincerity and self-restraint. We are reminded of Lamb : 
Her parents held the Quaker rule, Which doth the human feeling cool.

Dr. Du Bose is not at all a Quaker, but he has something of the admirable calm which we associate with that body. The colour of his book is grey, though we might well expect the imagination that is at work in it to make its glow felt and seen through the pages. That it should do this so little is a mark of strength-of the same quiet unconscious strength that is the dominant quality throughout. I hope, if all's well, before I have done, to give an example of the highest point of dithyrambic eloquence to which the book attains. Even that I think will be pronounced sober enough.

To sum up this descriptive part of my notice. It is a strong, grave, penetrating book, that would be austere if the thought were not too rich and deep and elevating for austerity.

But I must not forget that I have not even jet explained the purpose of the book and the place that it holds in literature. It is not a Life of Christ, and yet we shall perhaps understand its object best if we compare it with Lives of Christ. We have had these of various kinds: we have had picturesque Lives, and we have had learned Lives. The Gospel in the Gospels does not aim at being either. It is indeed potentially more learned than it may seem. One whose own work is concerned with the same subject can read between the lines; he can see more knowledge of the modern treatment of it than is allowed to appear. Dr. Du Bose is in truth entirely modern. But the distaste for 
details of which we have spoken limits the influence of this to results; it does not lei us see the process that leads to the results.

Dr. Du Bose calls his book The Gospel in the Gospels. It is not a complete picture of the Life of Christ. It is not an attempt to place that picture in its historical setting. In other words, it is not an attempt to reproduce and modernize the substance of the Gospels, so far as that substance is capable of being presented as it were visibly to the eye of the mind. But it is rather a sustained endeavour to get at the inner spiritual meaning that lies behind all such external presentation. It is a high and serious effort to determine the principles at work in the Life of Christ, to express them in the most compact and abstract form, and to view them in their inner coherence and mutual relations. We might call this a philosophy of the Life of Christ: it belongs throughout to the region of philosophy, or philosophical theology, as opposed to that of history or criticism.

It might be expected that there would be some difficulty in delimiting the two spheres, some confusion of their natural boundaries. As a rule this has been avoided very successfully; the book is a complete and rounded whole, with its outline well defined. There is only just one single case that I am inclined to think of as an exception. The Temptation of our Lord seems to me best treated historically, in relation to the recasting of the Messianic idea. I cannot help thinking it rather artificial to bring the three temptations under the heads respectively of Faith, Hope, and Love. 


\section{$X$. 'The Gospel in the Gospels'}

I cannot remcmber anything else in the book to which I could give such an epithet; but it seems to me in this instance due to the cause I have mentioned, the attempt to bring under philosophical or theological categories a problem that is primarily historical.

\section{II}

The book, as I have already said, is planned in three main divisions: considering, (1) the Earthly Life of our Lord; (2) His Work; (3) His Person. This three. fold division is the carrying out of a very interesting principle laid down in the Preface. Dr. Du Bose is very sympathetic towards modern thought; he feels that, in view of the present position, a different attitude is advisable from that which was characteristic of early Christianity. The early Christians held that truth is a whole, and that anything that came short of full truth was by that very fact condemned and excluded. Dr. Du Bose, on the other hand, holds that even partial truth is true as far as it goes-' that the Gospel of Jesus Christ is so true and so living in every part that he who truly possesses and truly uses any broken fragment of it may find in that fragment somethingjust so much-of gospel for his soul and of salvation for his life.' In pursuance of this principle the argument works its way upwards ; first, through the lower stage of the earthly life of Christ, His common human. ity with ours, considered as such; then, through the contemplation of His Work, as centring in the Resurrection; and so lastly to 'the gospel of the Person or the Incarnation '. 
I am not quite sure that this scheme is altogether a success. I am much inclined to go with the principle from which it starts; and the first part seems to me really to form a rounded whole. But $I$ am not so clear that a dividing line can be drawn, in the same sense, between the second and the third. I doubt if we can frame an adequate appreciation of the Work of Christ apart from presuppositions derived from our estimate of His Person. I may even go further than this, and raise the question whether it is possible to attach any special value, such as Christians attach, to the Work of Christ without bringing in the higher Christian conception of His Person.

I have therefore a little wondered how far the leading idea of the Preface may have been an afterthought. But, however that may be, the real evolution of the book is less materially affected than we might perhaps at the first blush have supposed that it would be. There is indeed, as I have implied, a certain amount of inevitable anticipation of the later stages in the earlier; but this is not at all excessive, and the natural upwards progression of the thought is not much disturbed.

Part I, which stands by itself more distinctly than the other two, deals in succession with, The Impression of the Earthly Life of Jesus (chap. i); The Growth and Preparation of Jesus (ii); The Divine Sonship of Humanity (iii); The Son of Man (iv); The Kingdom of God (v); The Authority of Jesus (vi); The Blessedness of Jesus (vii); The Beatitudes (viii, ix); The Death of Jesus (x). 
As I do not propose to return to this division of the book, I will give a single specimen to show what it is like. The passage is interesting, because it rather markedly - but I suspect quite independently-coincides with much that is being said in quarters very far distant from Sewance. There is a tendency ' in the air' at the present time to qualify the old conception of meekness.

Men, according to Aristotle, in the spirit and temper of their dealings with one another, should be controlled by a disposition which he calls meekness or mildness or gentleness. The term is the best we have, he says, but it is inadequate, it is not positive or strong enough. Moses stands out as a type of the Hebrew righteousness; he might be said to have been the creator of it. And we speak of the meekness of Moses as though that were his distinguishing trait. But surely we have all felt the inadequacy of the term meekness to express the character or disposition of Moses. Our Lord seems to have selected the same term to express His own fundamental disposition. Take my yoke upon you, He says, and learn of me. For I am meek and lowly in heart; and ye shall find rest unto your souls. And yet we too feel that the word meck is scarcely the one to describe Jesus. We feel even that too much application of that term to $\mathrm{Him}$ has weakened the popular conception not only of Himself but of Christianity. It has contributed perhaps to the too negative and colorless interpretation of His great principle of non-resistance. . . . In the so-called meekness of Moses there is a lofty unselfishness, a great humility, a perfection of zeal and devotion, which momentary weakness and impatiences scarcely detract from. The Law and the Prophets between them were productive of great types. But the perfection of human spirit and temper waited still for its realization and manifestation. 
When Jesus speaks of the meek, He speaks of Himself. He speaks of that attitude towards men under all possible conditions of provocation and trial which $\mathrm{He}$ had deliberately made $\mathrm{His}$ own and which never deserted Him under any temptation to the contrary.... I do not know how we can define or describe in abstract terms the peculiar meekness, or what is attempted to be expressed by the meekness of Jesus. The thing is ever more and greater, and even different, from its best expression. That is why God never gives us definitions or descriptions of things, but always manifestations of the thing itself. . . . But the interesting point about the beatitude is this: the perfect assurance of Jesus that the right, the true attitude of man toward man will be the ultimately successful and surviving attitude. The meek shall inherit and possess the earth. The spirit and temper and disposition of Jesus, because it is the fittest, because it is that which alone gives true meaning and value to life, because it is the only bond of perfect relationship and intercourse among men, will survive and prevail (pp. 99-IO:).

It would be too bad to call attention by italics to one of the few sentences here and there that do not construe ('greater . . . from'), but I do so really for another purpose, as an instance of the wise incidental sayings that are scattered far more freely over Dr. Du Bose's pages. We shall come across others in the sequel.

The passage as a whole may be taken as a good average sample of the freshness and originality with which Dr. Du Bose writes. But we go to him especially as a philosophic theologian on a large scale; and it is to this aspect of his book that I shall confine myself henceforwarcl. 


\section{III}

It is just a full lustrum since it fell to me in The Expositor for May I 90 I to review my dear friend Dr. Moberly's Atonement and Personality. I was led to say of it that it was long since I had seen a book that gave one so much the impression of having been really thought out. It was neither more nor less than a system of theology complete in itself. I should now say just the same thing of The Gospel in the Gospels. And-what is still more remarkable-not only is this too real a system, completely articulated in itself, but it is practically the very same system. Rarely can it happen that two writers, at a distance of some five thousand miles from each other and brought up in circumstances entirely different, each following the train of his own thought and without any direct communication, should arrive at results so nearly identical. I know that Dr. Moberly had read an earlier book by Dr. Du Bose; and I believe-though I am not sure-that Dr. Du Bose is acquainted with the writings of Dr. Moberly. But I am convinced that in neither case does this fact, so far as it is a fact, at all impair the originality of the development. Both are eminently logical writers; and their logic-the logic of no sudden impulse but of a lifetime-has led them from the same premises, by the same method, to the same conclusions.

This is very conspicuous over the whole of the ground covered by Dr. Moberly's volume, which (as I have said) was remarkably comprehensive. The 
whole theory of Personality and the whole theory of Atonement in the two books coincide.

Dr. Moberly, it will be remembered, put forward a view of Personality that seemed to many paradoxical. He held that true freedom of the will consisted, not in the licence of doing simply what one pleased, but in the gradual conforming of the human will to the Divine. He held also that the perfecting of the Self is not to be had in distinctness or isolation, but by the permeating and penetration of the human spirit by the Spirit of God. Both these fundamental thoughts appear repeatedly in Dr. Du Bose.

The American scholar insists quite as strongly as the English that the real atonement or reconciling of man to God can only be completely brought about by this action of the Holy Ghost. As Dr. Du Bose puts it:

It is not the Gospel nor the kingdom of God nor salvation to men that they shall be made the objects only of all the mercy and the goodness of the universe. Nothing can be done merely to us or for us that will save us. To be loved, to be sympathized with and helped, to be shown mercy and forgiven, to be the objects of the most unconditional divine grace, are a very great deal. But these are the merest circumstances of human salvation, they are not salvation itself. No one saw more clearly than our Lord that life and blessedness is not what is done to us, but only in what we ourselves are and do.... Therefore, Jesus quickly and decisively passes from the consideration of men as the mere recipients or objects of the goodness of God, of which He was the almoner, to the higher thought of them as the subjects of the divine goodness, as partakers and sharers of the divine spirit and nature and life of love and goodness (p. 66). 
Not less uncompromising is the following:

All the reality in the universe can be no Gospel to us so long as it remains objective, or until it enters into living relation with ourselves. Of course, it can never so enter unless there is in us the natural potentiality of entering into relation with it. But equally certainly that potentiality can only be actualized by ourselves. What is necessary within ourselves to give effect to all that is true without us is a corresponding response, or a response of correspondence, on our part. That correspondence is, I repeat, not a fact of natural relationship, but an act of spiritual communication or self-impartation. When the Spirit bears witness with our spirit, that we are sons of God, it is not only God who communicates the gracious fact, but it is God who awakens the humble and grateful response, and puts it into our heart to say, Abba, Father. . . It is through this eternal Spirit, which is God's and Christ's and ours, that we pass from ourselves into Christ and through Christ into God (pp. 286 f.).

It will be seen that the whole conception of Atonement or reconciliation is worked out essentially on the lines of Romans vi. The death of Christ upon the Cross was a death to sin, and to all that gave sin its hold upon humanity. But this death to sin had in it an inclusive virtue; it is an act in which every Christian is called upon and is enabled to share. The medium of this enabling is the indwelling of the Iloly Spirit, through which the believer is made one with Christ, so that he both dies with Him and also rises again with Him to newness of life.

All this is strictly based upon the teaching of St. Paul. But it is a satisfaction to see that the interpretation of that teaching is not so one-sided as it often 
is. There are some writers who, in laying stress upon Romans vi, seem to think that they can afford to neglect or forget Romans iii. Dr. Du Bose does not do this. He is careful to balance one side of his teaching with the other:-

Remission, or the putting away, of sin, includes two ideas, or perhaps more correctly two stages of the same idea. It means a real putting away by the New Testament process of sanctification. But it also means the provisional putting away by the equally New Testament act of divine pardon or forgiveness. Each of these two conceptions plays an important part in the drama of redemption or final deliverance and freedom from sin. And the complete meaning of each and perfect relating of both is no small part of New Testament doctrine (p. I32).

This other half of the process is elsewhere explained quite clearly and satisfactorily :-

Here comes in the other sense of remission, not as yet the complete impartation, but already the perfect imputation to us of the whole holiness, righteousness, and life of God as realized for us in Jesus Christ. The moment a human life has really made Jesus Christ its end, although that end be as yet only the end of purpose, and infinitely not yet the end of attainment, that moment God imputes to that life what it means and intends as though it had already accomplished it. St. Paul perfectly caught the principle, and perfectly expressed it in the doctrine which is the root of his system : Faith is imputed to us for righteousness; it is reckoned or accounted as being righteous (p. I 53).

It is the difference between the ideal and the actual, the beginning of a Christian's career and the end. That St. Paul should insist so strongly on this initial 
imperfect and anticipatory stage is due to the fact that we are most of us so much nearer to this stage than we are to the other. For us the process of dying to sin by repentance, of throwing ourselves into the work of Christ by faith, the struggle to keep ourselves from falling back, must needs take precedence of that perfecting of holiness, which will never be complete on this side of the grave. In practice we are obliged to start from the actual, and to look at things as they are ; but it is a great help to us in theory to look at the process as a whole, to see it not in the light of our weak and uncertain efforts, but as it is consummated through Christ in God.

\section{IV}

The reader who is familiar with Dr. Moberly's great work will be constantly reminded of it in all that is said by Dr. Du Bose on the double subject of 'A tonement and Personality'. The fundamental lines of thought are the same; and they are laid down with equal firmness and lucidity. But the resemblance between the two books is very far from ending here. I have spoken of both as containing what is really little short of a complete system of theology; and they might be described as almost doubles, one of the other, over the whole field. It would be really an excellent exercise to read the two books side by side; they will be constantly found to illustrate and supplement each other. Sometimes Dr. Du Bose states his thought with unusual boldness of concrete expression: but the 
logic of both writers is equally rigorous and essentially the same; and it is sometimes helpful to look for the premises in the one of the conclusions that are found in the other.

I will presently try to illustrate this. But the last division of Dr. Du Bose's book is so broad and so strong, and I may add so valuable, as a survey of the root ideas of Christian theology that I shall take advantage of it to give examples of the treatment of some difficult questions where its help seems to me specially welcome.

I will take first what is said about the mystery of our Lord's Birth. The extract will be rather long, but I only wish that it could be longer still; I cannot find in my heart to abridge it further.

While the order of things in themselves is always forward, the order of thought about things is backward, so that our last knowledge is that of adequate or sufficient causes. So Christianity may have rested for a moment upon the spiritual endowment of Jesus, as covered by His baptism or anointing with the Holy Ghost from heaven. But not for long; the explanation was inadequate; it was impossible to see in Jesus only a man approved of God by mighty works and wonders and signs. The deeper question of $\mathrm{His}$ person could not but follow after the others and gradually work its way to the front.... It says nothing against the Gospel of the Infancy as a direct naive record of facts, to recognize a more or less conscious or unconscious reason or motive for its introduction. It answered the immediate direct purpose of denying the human paternity of Jesus, and affirming for Him a divine paternity. When we speak, as we shall, of the motive or purpose in this, it is unnecessary 
to think of an explicit conscious intention on the part of the writers or of the Church. The truth shapes itself instinctively in the mind and expression of men, so that we often do not know why or how we say the things that are truest.

I cannot help pausing for a moment to point out once more what a number of wise sayings the passage I have been quoting contains, which are general in their bearing, and not confined to the particular topic under discussion. It is a real sage and seer who is speaking.

There is no part of the Gospels that has quite the poetic elevation of the Gospel of the Infancy. And yet what, at the last, one is most impressed with is its spiritual truth; if there is not the true instinct of the spirit there, in thought and language, it is nowhere to be found. Now what instinct of truth was it that in this effective way shaped the faith of the Gospel to the affirmation of not a human but a divine paternity of our Lord? I venture to say, that at any living point or period of Christianity the Christian consciousness concerning Jesus Christ would instinctively and necessarily have come to the practical conclusion embodied in the artless and poetical stories of the birth and infancy of Jesus. The profound speculative question really though invisibly at issue in and decided by them is this: Who and What is Jesus Christ, in His real and essential personality? The answer which this artless, and yet most profoundly artful, so-called nursery myth forestalls and excludes is this, $\mathrm{He}$ was no [?] mere natural offspring of Joseph and Mary. Why not? Because the product of every such natural union is an individual human person. Viewing Jesus Christ in that light it is impossible to construe Him otherwise than as a human individual, exceptionally favored by unique relations with God. The question for the 
Church then, as for the Church now or at any time, is, Can we, in the light of all that Jesus Christ is to the Church and to humanity, His universality, sufficiency, and ubiquity, can we, I say, be fully and finally satisfied to see in Him only one of the sons of men peculiarly favored and most highly endowed? I must confess for one, that however confronted and impressed with the rational and natural difficulties which we are about to meet in the opposite view, it is equally impossible for me not to be a Christian, or to be one under the conception of such a manhood of Jesus as the above. And I believe that in so saying I am expressing the normal Christian instinct and experience of the world (pp. 2 I $1-$ I 3 ).

It goes without saying that this conception of a humanity which is not that of an individual man is difficult. To understand it at all we need to bring in the doctrine of the Holy Spirit. Dr. Moberly warns us that the relation of Christ to the race 'was not a differentiating, but a consummating relation. He was not generically, but inclusively, man' ( $A$. and $P$. p. 86). The medium of this inclusiveness is the Spirit. It is through the Spirit of the Incarnate that the effects of the Incarnation are diffused among men.

The nearest analogy is that of Adam-' the First Man' of I Cor. xv. 47. But Dr. Moberly points out that the comparison is far from adequate.

It is valid as an illustration, but remains on a different, and dissimilar, level. The one is a fleshly relation, the other a spiritual. The one works automatically, materially, mechanically. The other is realized in a different sphere, and depends upon other than material conditions. The one is a natural property of bodily life, and follows, as it were blindly, 
from the fact that Adam was the original parent. The other is a Spiritual property, so sovereign, so transcendent, that it could only be a property of a Humanity which was not merely the Humanity of a finite creature, but the Humanity of the infinite God (op. cit. p. 89).

This last phrase ('the Humanity of the infinite God') is one that would be entirely endorsed by Dr. Du Bose.

While I believe that there was nothing revealed or manifested to us in Jesus Christ, save the perfection of His humanity, yet I equally believe that in that perfection there was infinitely more than the humanity so perfected. In other words, I see in Jesus not only the supreme act of humanity in God, but the supreme act also of God in humanity (Gosp. in Gospels, p. 2 I 3).

Nothing is more characteristic than the even way in which these two complementary predications are balanced and the thoroughgoing unhesitating logic with which both are asserted. Occasionally we meet with expressions which would be almost startling, if they were taken out of their context. For instance this :-

Our Lord did not do that in our nature which no man within the limits of his own nature or by the exercise of only his own powers is capable of doing. He was not holy by nature, nor righteous by the law. The impossibilities of humanity were as much impossibilities for $\mathrm{Him}$ as for us. $\mathrm{He}$ bare all our weaknesses and carried all our sorrows. He had as much to hunger and thirst after a righteousness which was not His own as we have, and He did it infinitely more. If $\mathrm{He}$ was actually holy and righteous as none but $\mathrm{He}$ was or is, it was because $\mathrm{He}$ was possessed, and humanly possessed of a higher secret, a truer way, 
a more sufficient power, of human holiness and righteousness than human nature in itself contains or human will can by itself acquire. ... He was holy as a man and in the only way in which a man can be holy. $\mathrm{He}$ was holy by the conquest of sin. And this $\mathrm{He}$ was and did, as we too must be and do, after Him and in $\mathrm{Him},-$ not within the limits of our own nature, nor by the powers of our own will (and yet not without these too), but through His all-sufficient way of perfect union and unity with God (pp. 163 f.).

This is one of the instances in which, though Dr. Moberly does not (I believe) use quite the same language, he yet explains the principle on which it is used :-

Christ is, then, not so much God and man, as God in, and through, and as, man. $\mathrm{He}$ is one indivisible personality throughout. In His human life on earth, as Incarnate, $\mathrm{He}$ is not sometimes, but consistently, always, in every act and every detail, Human. The Incarnate never leaves $\mathrm{H}$ is Incarnation. God, as man, is always, in all things, God as man. He no more ceases, at any point, to be God under methods and conditions essentially human; than, under these essentially human methods and conditions, $\mathrm{He}$ at any point ceases to be God. Whatever the reverence of their motive may be, men do harm to consistency and to truth, by keeping open, as it were, a sort of nonhuman sphere, or aspect, of the Incarnation. This opening we should unreservedly desire to close. There are not two existences either of or within, the Incarnate, side by side with one another. If it is all Divine, it is all human too. We are to study the Divine, in and through the human. By looking for the Divine side by side with the human, instead of discerning the Divine within the human, we miss he significance of them both ( $A$. and $P$. pp. $96 \mathrm{f}$.). 
The American and the English scholar are quite at one on this ground. As a rule they both keep closely to the lines of patristic divinity. This is eminently the case with regard to their teaching as to the nature of the humanity assumed by Christ. Dr. Du Bose more than once quotes Irenaeus; and he has striking points of contact with the teaching of that father, and of St. A thanasius. But in the extracts just given there is a perceptible difference from the doctrine of the Two Natures, as it is given (e.g.) in the Letter of Pope Leo to Flavian.

I have the impression that in this respect the moderns have really improved upon the ancients. The consequences of this re-statement are rather far-reaching. One of these may be seen in a passage by Dr. Du Bose, which is as near to a climax as anything in the book. But I will quote first a later passage, which serves to explain the earlier:-

The hesitation and reluctance to see all God, and highest God, not only in the humanity but in the deepest human humiliation of Jesus Christ, is part of the disposition to measure exaltation by outward circumstance and condition instcad of by inward quality and character. We find it impossible to recognize or acknowledge God in the highest act of His highest attribute. We cannot listen to the thought that it is with God as it is with us, that it only is with us because it is with God, that self-humiliation is selfexaltation (p. 284).

That is a kind of boldness that I do not think we should have found in any of the ancients. And I cannot help thinking that it is superior to the Kenotic 
teaching of many moderns. At any rate the application of it which follows is deeply impressive.

We speak of the incredible and impossible selflowering or self-emptying of God in becoming man or in undergoing the death of the cross. Is the act in which love becomes perfect a contradiction or a compromise of the divine nature? Is God not God or least God in the moment in which $\mathrm{He}$ is most love? Where before Christ, or otherwise than in Christ, in whom $\mathrm{He}$ humbled Himself to become man, and then humbled Himself with and in man to suffer what man must needs suffer in order to become what God would fain make him-and the highest and best that even God can make him-I say where before Christ, or where now otherwise than in Christ and in the cross of the divine suffering together with and for man, where in all the story of the universe was or is love so love, or God so God? (pp. 272 f.)

\section{$\mathrm{V}$}

I hope it will not be thought that I have been too copious in quotations. I have been very anxious to let Dr. Du Bose speak-and speak adequately-for himself. I desire to give my readers an idea of what his book really is. I have the feeling that a few samples, which are really characteristic, will be better than much description, even if I could trust myself to describe with sufficient accuracy. And I did not consider myself called upon to resist the temptation to place a great English book by the side of a great American. The epithet is one that I will take the risk of giving to both.

At the same time my readers will kindly remember that what I have given them has been only samples. 
Dr. Du Bose's book is full of good things at which I have been unable even to hint. To do it justice, it should be read carefully, and read through, from beginning to end. If the specimens I have given should arouse in any one the instinct of opposition, that may be perhaps partly because I have given prominence to what lay most outside the beaten track. But the reader may be assured that there is a great deal beside this which is said with admirable freshness and force.

But the thing that perhaps strikes me most in the book is the wholly unconscious (i. e. un-selfconscious) loftiness and largeness of the point of view. The work is that of a serenely contemplative mind-a mind that has fixed a long and steady gaze upon its great theme until the outlines stood out luminous and clear. The writer of this book has had the whole of Christianity before him. Like Jacob at Peniel, he has wrestled with its meaning, not excitedly or passionately, but ' in the quietness of thought'; and his patience has had its reward.

I will just give a last illustration of the largeness and comprehensiveness of view of which I have spoken. We might call it nothing less than a definition of Christianity.

I would describe Christianity in its largest sense to be the fulfilment of God in the world through the fulfilment of the world in God. This assumes that the world is completed in man, in whom also God is completed in the world. And so, God, the world, and man are at once completed in Jesus Christ-who, as He was the logos or thought of all in the divine fore- 
knowledge of the past, so also is He the telos or end of all in the predestination of the future. That is to say, the perfect psychical, moral, and spiritual manhood of which Jesus Christ is to us the realization and the expression is the end of God in creation, or in evolution. I hold that neither science, philosophy, nor religion can come to any higher or other, either conjecture or conclusion, than that (p. 274).

When we have thus adequately conceived Christ as the universal truth and reality of ourselves, and in ourselves of all creation, and in creation and ourselves of God, then we are prepared for the conclusion that we know God at all, or are sons to Him as our Father, or are capable of that relation of partaking of His nature or entering into His Spirit or living His life, only in and through Jesus Christ; because Jesus Christ is the incarnation or human expression to us of the whole Logos of God-that is to say, of God Himself as in any way whatever knowable or communicable (p. 279).

We may turn this round and express it, no longer in the terms of reasoned theory, but in those of religious experience, as follows :-

Jesus Christ has not come so much to create the kingdom of God without us, as to create within us the power to see it. I am come, He says, that they which see not may see. What He saw and what He would have us see is: all the eternal love that God the Father is, ours; all the infinite grace that God the Son is, ours; all the perfect fellowship or oneness with ourselves that God the Holy Ghost is, ours. If all this is ours, then all things are ours, and all blessedness is indeed ours (p. 96).

It would not be easy to end on a more characteristic or a finer note than that. 


\section{XI}

'THE GOSPEL, ACCORDING TO ST. PALL''

Ayerica should make much of Dr. Du Bose. 1 strongly suspect that in his own proper field-which I might perhaps describe as the Philosophy of the Christian Religion-he is the wisest writer on the other side of the Atlantic; incleed it may not be too much to say, the wisest Anglican writer (with so French-looking a name it seems wrong to speak of Anglo-Saxon, and it narrows the ground a little to confine it to a single communion) on both sides of the Atlantic.

America should make much of him-and by this I mean, not so much praise and honour him (America is sure to do that to any one who is worthy!) as utilize and assimilate his work and thought for its own advantage. It should do this just because there are features about him that are not in the narrower sense American. He might be described as an encouraging example of what one American type may come to; but this particular type is, I imagine, not at present largely developed, and therefore it is all the more valuable. It differs a good deal from the type or types with which we are most familiar.

1 The Gospel according to St. Paul. By W. P. Du Bose, M.A., S.T.D. London and New lork, 1907. 
First and foremost-and indeed perhaps everything in a word-here is an American who is not in a hurry, as he might himself say, 'tremendously not' in a hurry! Not that I am going to blame the American hurry; it is natural enough and right enough, for a nation situated as they are. They have a big continent to subdue; and they feel its promise; and it is not strange that they should also feel that no time is to be lost in subduing it. That feverish energy is accomplishing, and will accomplish, great things.

But something more is wanted for a nation really to possess its soul. That something is wisdom; and wisdom cannot be had without calm. And therefore it is that it seems to me that America must specially prize this quality of calm; all the more where, as in the case of Dr. Du Bose, it is calm of the right kindactive and not passive, a quiet self-contained and selfcontrolled creativeness, that hastes not and rests not, like the great Creator Himself.

This quality is impressed upon the opening chapter, and so strikes the key-note of the whole book. We feel at once that we have to do with a large outlook upon the world and upon the ways of God with menan outlook large, considerate, and intrepid, strong and yet dutiful, untroubled and unshaken by anxieties either without or within.

The ultimate aim of each one of us should be not to save ourselves from error, but to advance the truth. We may safely rely upon it that our truth will in the end be accepted and our error corrected.... I hold what I hold subject to the revision and correction of 
XI. 'The Gospel according to St. Paul' ${ }_{28}$

the deeper truth of the Scriptures and the larger wisdom of the Church. ... There are those who object to our making salvation, the life of the spirit, the life of religion in general, too natural a process. We cannot kick against the pricks, the world has begun to make the discovery, and it will not go backward in it, that the natural is God's way. The natural is the rational and the divine... . These are times-but, let us remember, not more so than were the earliest and most living ages of Christianity - of thought and speculation, original and independent thought and speculation, upon the truth as it is in Jesus Christ. They are not times of unthinking and unquestioning acceptance of foregone and foreclosed inquiry and investigation. The fact may be condemned and lamented, but no amount of shutting our own or others' eyes and ears to it will make it any the less a fact. ... The position here taken is, to my mind, independent of any present or future conclusions of scepticism or criticism with regard either to the Scriptures or the Church. I fully recognize not only the function, but the necessity of both scepticism and criticism, in their true meaning and use; and I presume neither to limit nor to define these. But the fact will always remain that we receive our Christianity through the Scriptures and the Church, and that these are the tribunal of final resort for determining what Christianity is (pp. $3,4,8,9, \mathrm{I}, \mathrm{I} 4$ ).

No doubt there is at the present time in many quarters a disposition to go beyond this, not so much to appeal to the Scriptures as to sit in judgement on them, and to ignore the mind of the Church. That is very largely the attitude of critical schools on the Continent of Europe. But I think we may be thankful that Dr. Du Bose draws the line where he does; it is certainly not either narrow or illiberal. 
Most of my readers will be aware that the volume now before me and of which I am to give some account is practically the continuation of another published about a year ago under the title The Gospel in the Gospels. I had the privilege of reviewing this earlier work in The Expositor for May, 1906, and I will not repeat what I there said. Just as the earlier volume aimed at giving in a connected form the essential meaning of the Gospels, so the present volume aims at giving in like manner a connected view of the leading or root-ideas of St. Paul. It is substantially a commentary on the first eight chapters of the Epistle to the Romans; not a commentary of a formal kind with detailed notes on each verse, but rather a series of essays upon the epistle taken section by section, and trying to bring out broadly what is most central and permanent in the contents of each. I do not think that we have anything quite like it in English : and yet it is just what most of us, or at least those of us who are general readers, would wish to do for ourselves; the professed student needs to study his text closely word by word, but the general reader prefers to hold his text as it were at arm's length and to see the leading thought in it stand out in clear relief. It is just in this way Dr. Du Bose seeks to help him; what he gives is practically a succession of bird's-eye views of the paragraphs and divisions into which the text of the epistle naturally falls.

I do not think we can be surprised that Dr. Du 
$X 1$. 'The Gospel according to St. Paul' 285

Bose should make his discussions revolve round the Epistle to the Romans in this way. His book certainly is a complete and coherent presentation of the fundamental ideas of the Apostle's teaching; and it adequately represents and summarizes the main points in the two earlier groups of epistles; it also no doubt made the whole task easier, to be able to follow the outline of a single continuous argument. And yet perhaps this procedure is open to the criticism that it does not quite take in the whole of the Gospel according to St. Paul. The later epistles bring out some sides of it-more especially that side which presents the closest parallel to the Logos doctrine in St. John and the relation of Christ to the Churchwhich are but slightly touched upon in the Epistle to the Romans and therefore practically fall out of Dr. Du Bose's purview. Perhaps it may be said that these are not strictly parts of 'the Gospel', but rather corollaries or developments of it. The Gospel is primarily the glad tidings of salvation; and the whole groundwork of salvation is fully and searchingly treated.

In my previous review I had occasion to point out the great completeness and coherence of Dr. Du Bose's teaching. It is no mere aggregation of loosely related doctrines but essentially a system, and a system well knit in its parts and carefully rounded off as a whole.

And another remarkable thing that I had to point out was the close resemblance which this system presents to that which we in England associate with 
the name of Dr. Moberly. As we were fated to lose the one writer before his time, our satisfaction is all the greater that the other should survive to continue his work; for The Gospel according to St. Paul not only takes up the The Gospel in the Gospels, but also, if it does not exactly take up, at least reviews and to a great extent goes over the same ground as Atonement and Personality. It might be said to be a restatement, with characteristic difference of language and independence of thought, of the teaching of that book.

Perhaps one's first thought is that the new book does not add much of quite fundamental importance to the old. The root-ideas of both books are the same. We might at first sight suppose that the later work was only the arrival of a strong reinforcement in aid of the earlier, the appearance on the field of a weighty champion of the same cause. But, when we come to look into it, we see that there is really more in the matter than this. The six years that have elapsed have not been in vain. It is, I think, true that no new factors are introduced in the treatment of the main problem. But at the same time the restatement is so careful and so searching and so balanced that it seems to me to constitute a real advance. I will venture to say even more than this. I cannot claim to have followed the recent literature of the leading subject involved very closely; there may have been anticipation of which I am not aware; but to me at least Dr. Du Bose's book seems to offer something very like the definitive solution of an age- 


\section{XI. 'The Gospel according to St. Paul' ${ }_{287}$}

long controversy. Just as the Gospel of St. Paul and the Epistle to the Romans have been the chief battle-ground of that controversy, so what I conceive to be the satisfactory solution of the main question arising out of St. Paul's Gospel, and his greatest Epistle, appears to carry with it a virtual and sufficient settlement of the controversy that has gathered round them.

The reader will guess that I am referring to the vexed question that has agitated the Christian world in an acute form for nearly four centuries, the question that will perhaps be best understood if I call it by its old name, the doctrine of Justification by Faith.

It seems to me, if I am not mistaken, that $\mathrm{Dr}$. $\mathrm{Du}$ Bose's statement of this doctrine, with perhaps one or two cautions added by way of explanation, furnishes the material for a more complete eirenicon than has hitherto been reached, and in particular for one that is more complete than was quite possible under the form in which the statement of the doctrine was left by Dr. Moberly.

I take upon myself to say this because I approach the doctrine from a different side-I might even say, from the opposite side-to both writers. They are close allies, and I am (so to speak), on this ground and within the limits of this particular subject, the enemy. But, if I am the enemy, I beg leave to say that I shall not only send out a flag of truce, but that I shall authorize my representative to conclude the terms of a permanent peace. 
It will make the exposition of my meaning easier, if I may be forgiven a certain amount of apparent egotism, and if I may go back to an article of mine in The Expositor for May, I 901 , reviewing Dr. Moberly's Atonement and Personality. In that article I tried (I am well aware how imperfectly) to state a case for a more old-fashioned view, and I pleaded that in the Christian Church alternative views should be regarded as tenable. In that, I confess, I was altogether wrong. The two views are not alternatives that can be placed and tolerated side by side. I still think that there is an element of truth on the side that I was defending, just as I willingly and indeed eagerly acknowledged that there was a large element of truth on the side to which I was opposed. But the fact is that the opposing truths are not really in pari materia; they are not truths that can be held side by side; they belong rather to different spheres, and the reconciliation between them is to be effected, not by proposing the one as an alternative for the other, but by the careful delimitation of these different spheres.

Dr. Moberly and Dr. Du Bose are both primarily philosophers; the position that the one maintained and that the other now repeats is essentially a philosophical position. In regard to this, and in regard to the ultimate truth of things, they are both absolutely right. So far as I took up ground against this, I evacuate that ground with all my forces, horse, foot, and artillery. I knew that there was something wrong 
XI. 'The Gospel according to St. Paul' ${ }_{289}$

when I wrote, but I did not see where the error lay. I believe that (with the help of Dr. Du Bose) I now do see this. The reservations that I really wish to make are of another kind, and come under other heads; they do not belong to the region of philosophy, but in part to that of history, and still more to biblical exegesis and practical religion. In relation to the absolute truth of things, the truths that I desired to assert are subordinate, and can only be asserted as such. Dr. Du Bose, I am glad to say, sees this; and he so states the truths that are dear to him as to leave room for those that are dear to me. For this I am sincerely grateful to him. If his ally had lived (alas, that he does not, if only to welcome such congenial aid !) I do not doubt that we should have come to terms along the same lines; it is just the maturing and mellowing, and in my case the clearing of the brain, that where the heart is right comes with time.

At this point I do not think that I can do better than try to set forth Dr. Du Bose's teaching as far as possible in his own words. When this has been done I will add a few remarks; but in the meanwhile I will take the liberty of italicizing those parts of the statement that are especially welcome to me as keeping an opening for those supplemental truths that I contend for. In the case of single words the italics are the author's.

I have described the main issue as turning round the doctrine of Justification by Faith-of course, in the largest sense, with all that goes with it. I use this familiar phrase because it will probably best cover 
the ground and call up the history of the subject, with all those kindred issues and sub-issues that we associate with it. Dr. Du Bose does not use the phrase often; indeed it may be said of him generally that he avoids hackneyed technicalities, with the best result for freshness and reality of presentation. The chapter of his book which corresponds most nearly to what we might call Justification by Faith is headed 'The New Righteousness'. The 'New Righteousness' is naturally that teaching on the subject of righteousness, in relation at once to man and to God, which is most characteristic and distinctive of St. Paul and of the Epistle to the Romans. The asserting of the New Righteousness is based upon the break-down in actual fact of the Old Righteousness, so far as that depended upon human efforts after the observance of law.

No man who knows what righteousness is, will come into God's presence with a claim of his own to it. ... The Gospel of Jesus Christ was for sinners of every type save the impossible one of self-righteousness. This sense of being received, accepted, regarded, treated, as righteous is carried on from the mere negative statement under consideration to a positive form of it which gives a new and important step in St. Paul's Gospel. It is this being treated as righteous, not on the ground of being righteous, but on the ground of a certain relation of faith to Christ's righteousness, upon which is laid the chief emphasis in St. Paul's system (p. 7I).

Nothing can be more explicit, on a point where one is glad to see explicitness. Those who contend for the same ultimate conclusion as Dr. Du Bose have been too often tempted to evade the evidence which goes to 
show that St. Paul speaks of the sinner as 'regarded or treated as righteous', and not made actually righteous. This is further illustrated by the parable of the Pharisee and the Publican.

The Pharisee who went up into the temple to pray and reminded God of his own righteousness was not thereby justified; while the publican who afar off was conscious only of his own sin in the sight of God was, we are told, justified. That cannot mean either that he was recognized as actually being sinless, or that he was by act of God at the time made sinless, or righteous. The term 'justify' is not in the parable of the Gospel used in the developed, almost technical, sense of the epistle before us, but it is exactly on the line of it, and it illustrates the progress and the propriety of its later use. ... The publican is accepted on the ground of his, at the time, occupying the right posture or attitude. the only right attitude possible for him, towards righteousness and at the same time towards his own conscious unrighteousness. ... It is the attitude which negatively towards our own unrighteousness we call ripentance, and positively towards the righteousness of God we call faith.... The condition of possible or future righteousness is the right attitude or intention of mind and feeling towards actual present unrighteousness. ... In the initial moment of contrition the only possible and the necessarily first right posture of the sinner is that consciousness of himself which could not be the beginning of hatred of his $\sin$ if it were not to the same extent the beginning of a love of holiness. . . . Righteousness in us cannot begin otherwise than as an incipient sense of $\sin$ and that prolepsis or pre-vision and apprehension of holiness which we call faith. Faith is therefore with a divine truth and propriety reckoned or imputed to us as being righteousness, for 
it is a necessary moment or stage in our righteousness (pp. 72-4).

It will be seen how fully Dr. Du Bose recognizes what there is of truth in the view opposed to his own. At the same time he safeguards his own view by laying stress upon the end of the process, which is not complete until the sinner become actually righteous.

It is the end always that determines the meaning and nature of the thing, and the Gospel is the power of God unto an actual righteousness of men; and only by the way, or in a secondary sense, a gracious treating of sinful men, as not sinful, and of a faith which is not yet righteousness as being already such. . . . The Spirit of God, the holiness, righteousness, or life of God can do us no good save as they are our own, and they are our own only in our own possession and exercise of them. It is an infinite initial blessing, a present Gospel, to us that God does not wait for us to be good, that He takes us to Himself from the moment of the birth in us of the will to be good, and by treating us as though we were makes us good. But let us beware of stopping with the Gospel of being accepted and not going on to the real Gospel of being good. For there is no other real good for man than that of being good, of his own goodness. Any other is only a blessing on the way, a refreshment, and a help to the consummate end and blessedness of being what God is. And let us remember, too, what the goodness is that is our only real good. It is the spirit, nature, and life of God, it is love, service, and sacrifice. We have heard it said, I am content to be a sinner saved by grace. In the first place, in its truest and highest sense, to be a sinner saved is to be one who having been a sinner is so no longer; to be content to be saved in and not from sin, to be saved and still a sinner, is no true contentment ... For one in that stage and attitude 


\section{XI. 'The Gospel according to St. Paul' 293}

of faith and waiting, it is indeed a present though not the whole or highest blessedness of the Gospel that we are already, with God and in faith, all that we shall be in God and in fact. Indeed, in St. Paul's immediate crisis of thonght and contention, this stage and phase of the matter is so uppermost for the time that he almost scems to treat it as the whole Gospel. He never really does this, though his ardent and one-sided partisans have abundantly done so ever since. St. Paul has ever in his own mind the whole undismembered conception of salvation in Christ, but he is passionately in earnest in establishing the present gracious status of believers as already and completely in possession in faith, though not yet in fact, of all that God has made ours in Christ (pp. 76, 78, 79).

Dr. Du Bose is certainly not an 'ardent and onesided partisan', though he is really more 'ardent' than his calm and deliberate language might lead us to suppose. I value especially the last sentence which I have italicized, because it does justice-and at last full justice-to the real mind and purpose of St. Paul, which I cannot help thinking was a little twisted even by Dr. Moberly.

There is another phrase that I must italicize, because as between the joint position of Dr. Du Bose and Dr. Moberly and my own it is very important.

The response of the Gospel to the human sense of actual sin and unattainable holiness is not the half-grace of forgiveness but the whole-grace of redemption and deliverance. God manifests Himself in it, that is to say, in Jesus Christ, not as pitier and pardoner of man in his sin, but as redeemer and saviour of man from his sin. He is there seen, in all the completeness of justifying, sanctifying, and saving grace, as at once Righteous and righteousing or Righteouser (p. IO2). 
We note in passing that Dr. Du Bose sticks to his guns in regard to such coinages as 'righteousing' and 'immanental'. Attention was called to these by several critics of the earlier book, especially on this side of the water. But I confess I think, with his second book before me, that its author is right in keeping the words and ignoring the criticism. $\mathrm{He}$ is right, I believe, doubly in these cases; at once because they come naturally to him-it is part of his idiosyncrasy to be rather fond of coining new words, and these particular words serve a real purpose in the expression of his thought-and also because they fill conveniently a vacant place in the English language. We want something to correspond not only to 'transcendent' but to 'transcendental', and we also want something which can be treated as the exact equivalent of the Greek $\delta$ เxaıviv, covering both the sense of 'to account righteous' and 'to make righteous'.

The next passage that I shall quote illustrates, not perhaps quite favourably, one or two little turns of expression that are characteristic of the author's style -he is especially fond of the figure 'zeugma', and I am not sure that there is not some slight risk of its becoming not only a manner but a mannerism. However, it is of course not for this reason that I quote the paragraph, but because it will help to complete and explain the thought to which I have just referred.

John the Baptist's preaching and baptism contained everything that belongs to religion except, as he himself confessed, the power of it or the possibility of its realization. As has been more than once said, not 
only the primary condition, but the actual first step in religion, by which we mean the right relation of man to God, is the knowledge and sense or feeling of his own condition, his wants, and above all his own not only shortcomings or failures but transgressions and sins; and not only his sins but his sin. The prodigal felt not only that he had sinned, but that, deeper than that, he was a sinner. Everything depends upon man's own attitude towards $\sin$ and his own $\sin$. That attitude we express by the word repentance. Applying again the principle that a thing is truly defined only by what it is in its completeness, I say that repentance means the putting away of sin. In the first place it means the actual putting it away, and in the second place it means the putting it away by the sinner himself. Any desire or any conferring of only pity or pardon is only, at the best, an imperfect or incomplete either repentance or remission. And in the second place, even God Himself can in the full sense confer the true remission or truly put away sin only as $\mathrm{He}$ can impart a true repentance or the inward disposition, power, and act of the man in himself putting away his sin. A real aphesis is neither if it is not both God's and the man's act (pp. IO4 f.).

I will conclude the exposition of the train of thought which we have been so far following with the description, which really belongs to it and crowns it, of the state of peace into which the Christian enters.

The first immediate consequence of the blessedness made ours in Jesus Christ is the sense of present peace. It is necessary to make a distinction between this present peace and what we may term real peace, -if it be only for the purpose of taking in the gift of God in its entirety, its end as well as its beginning and progress.... To one who is ill and about to die it would bring great present peace to know that he was brought into possession of certain 
cure and so of assured recovery and health. But the real peace to the sick man is health itself, and the wonderful comfort and peace brought to him by a sure faith in it and a certain hope of it is, in a large measure at least, only proleptic or anticipatory. In a large measure, but not wholly so. The patient may find in his very anticipation and hope a real beginning and progress of the return of actual health, and so his possession and enjoyment may be not all only future; and the believer not only looks forward in faith and hope to the actual fruition of God and holiness and life, but has an ever increasing foretaste of them now. That, too, is real peace so far as it goes, and is to be classed, in theological language, rather with the real peace of sanctification and final glorification than with the immediate present peace of justification. ... If the worst sinner at this moment in the world could be brought to an immediate spiritual apprehension of the full meaning of Christian baptism, what it is that is made all ours by that divine instrument, assuredly that act of spiritual apprehension on his part would be the first tremendous step in the process of real righteousness, or sanctification, on his actual way to God. But of real righteousness, or righteousness of his own, how little would it be! Of real reception or reception by actual participation there could indeed be but a drop from the infinite ocean : but, on the other hand, by the reception of faith and hope, or of anticipatory appropriation, it can be all his in a moment. He may in one ecstatic sweep of vision behold all God become human, his own, righteousness and life. In that one happy moment, or in the longer happy moment, of his whole earthly life of faith and hope, it is not his own paltry attainment of personal righteousness or life with which God credits him. Rather it is all that his faith takes in and appropriates to itself of the infinite and eternal righteousness of God Himself. All of Jesus Christ, who is God's promise and gift to us of His 
own divine righteousness,-all of Jesus Christ, who is consequently also our own perfect actual participation in the righteousness of God-is reckoned, accounted or imputed to, it as is were put to the credit, of the worst sinner who by a true faith accepts and appropriates Him to himself (pp. I 29-3I).

In the latter part of this last paragraph new thoughts come up, about which more will be said later. But in the meantime, what a noble outburst in the midst of all this severe reasoning, is that 'one ecstatic sweep of vision'! It is a grand expression of that complementary truth for which I would plead.

\section{III}

When all concessions are made-and in the passages I have quoted there is much that, if not exactly put forward as concession, is at least qualifying truth-it will still be seen that Dr. Du Bose, like Dr. Moberly before him, is rigorous and uncompromising enough. Not many pages are allowed to pass anywhere in the volume without some reminder that the only righteousness in which it is possible really to rest is the man's own actual righteousness, not imputed but imparted and realized in himself. It is to me a marvel what multitudinous ways are found of saying this one thing in different words. I should have thought the iteration almost excessive; but I can understand the wish to drive home this point, in view of the extent to which a laxer theory has prevailed.

Both with Dr. Du Bose and with Dr. Moberly the whole weight of character, temperament and intellec- 
tual leaning told in the same direction. In both writers there was and is an innate veracity that is intolerant of any form of fiction. In both writers there was and is an intense moral earnestness that could not be trifled with. Both writers manifest a keen sensitiveness to the currents of modern thought, especially those that are often directed against Christianity. And lastly, both writers are philosophers, in quest of a complete moral theory of the universe, and unable to acquiesce in anything less.

And yet there is another point of view; and, whatever condemnation I may bring down upon myself by the confession, I must confess that I have shared in it myself. That theirs is the better part I willingly acknowledge. But some of us could not help saying under our breath, when the theory was broached, $c$ pur si muove-in a reactionary sense the opposite of Galileo's; we felt that after all there was an element of truth in the discarded propositions.

Suppose one, perhaps not wholly without a sense of veracity, but yet sufficiently a student of past history, to be aware that God has allowed a great deal to enter into His plans for mankind that is not exactly naked truth as it stands. Suppose one, further, who though not altogether indifferent to the claims of righteousness was yet very conscious of living in a mixed world in which those claims could not always be asserted to the uttermost. Suppose one, yet again, upon whom the 'mystery of things' weighed somewhat heavily, who felt that he could believe an ordinance to be divine without being able at once to see all the reasons 
XI. 'The Gospel according to St. Paul' 299

for it. Suppose this same person to have a kind of natural drawing towards the publicans and sinners as contrasted with 'the unco' guid or the religiously righteous'; and suppose that in yielding to this natural drawing he was conscious of a special attraction in the idea of 'free forgiveness'; and suppose that the atmosphere in which his mind habitually moved was that expressed in Browning's

\section{What I aspired to be, \\ And was not, comforts me.}

Suppose a mind like this in an attitude of inquiry, with no strong philosophic instinct and content with something a good way short of ultimate truth, but in part a student of the Bible and conscious how much both Testaments had to say about 'forgiveness' without any hint of anything behind or beyond, and in part an observer of the more pathetic side of human frailty. Is there not in these conditions the making. at least, of a different point of view from that of Dr. Moberly and Dr. Du Bose?

I believe that there is the making of such a different point of view. But I hasten to add, as I began by saying, that I am very nearly satisfied with the revised statement of the position as I find it now put forth by Dr. Du Bose. And I believe that he will accept the one or two modifications for which I should still like to ask. I should like to have a clear understanding that the actual righteousness for which he contends belongs strictly to the ultimate truth of things. That means that, for most of us, it will never be attained 
otherwise than very imperfectly on this side the grave. This is just a case in which we must let

the heavenly period Perfect the earthen.

We have the admission that, for St. Paul, in the Epistle to the Romans, the first stage and phase of the matter, the stage of repentance and forgiveness, 'is so uppermost for the time that he almost seems to treat it as the whole Gospel.' And the reason is obvious, because for so many of us it is the urgent, insistent, dominating stage in the practical experience of life. I, on my part, am quite ready to admit that ultimately, in the Divine counsels, there must be 'forgiveableness' corresponding to the forgiveness; but that is a question for God and for His government of the world, not for us; at least we may be content with the simple knowledge that it is there.

Dr. Du Bose has touched with a needle's point the heart of the matter when he speaks of 'the half-grace of forgiveness' and 'the whole-grace of redemption and deliverance.' But, having won our assent to this as a statement of underlying principle, he will I think lend an ear to our petition that it may not be used to the disparagement of forgiveness, which is far too precious and beautiful a thing to have disparaged.

The two views are not alternatives; the one is included in the other; it is the first step, the initial stage in the carrying out of the great scheme of salvation. All I would contend for is that this first step is for practically all of us so near at hand, so 


\section{$X I$. 'The Gospel according to St. Paul' 301}

important and so indispensable, that we cannot afford to relegate it to a second place even in thought. It is quite true that everything that can be called a scheme must be looked at as a whole, and cannot be rightly interpreted apart from its end. But at the same time, in the case before us, the end is so remote-it concerns us really in another state of existence than the present - that it seems to me even now that there is some lack of proportion in the relative treatment of end and beginning. At least we must always remember that Dr. Du Bose is a philosopher, and is writing as a philosopher.

\section{IV}

We are, of course, compelled to touch only upon a selection of points, and in that way much that is very noticeable has to be passed over. I should, however, like in passing just to call attention to what seems to me to be a particularly valuable paragraph on the place in history and in the Divine scheme of the Law. This is very apt to be misunderstood, and the following comments will do more than anything I remember to have seen to redress the balance.

There is so much said in St. Paul's presentation of the Gospel of the impotence and consequent superseding of the Law, that we are in danger of forgetting under his seeming disparagement how much he is really magnifying it. The fact is that the Gospel itself is only the Gospel in so far as it is the true, and the only, fulfilling of the Law. The Gospel is the power to fulfil the Law. And if there had not been first the developed experience and sense of the Law itself and 
of the necessity of fulfilling it; and then the no less true experience of the impossibility of the Law fulfilling itself in us, or of our fulfilling it in ourselves; and then again, the experience of actual transgression and the consequent sense of $\sin ,-$ if all this had not gone before, there would have been neither truth in itself nor possible meaning for us in the Gospel of Jesus Christ. The Law, therefore, was the most immediate and essential presupposition of the Gospel; and the Hebrew development of the moral sense and the moral law, the Hebrew passion for righteousness and sense of sin, was the most necessary historical preparation for the advent of the Gospel (pp. $24 \mathrm{f}$.).

But in regard to the train of thought that has so far been occupying us, the leading point that still requires to have something said about it is the objective ground of salvation; in other words, the Death of Christ. On this head I believe that the following will bring out the points that I should most desire to emphasize.

To go no further as yet, I am convinced that the term sacrifice and the idea or principle for which it stands can never be dispensed with. To begin with, it is not Jewish but universal, and although it has been and still is undergoing the refining and purifying treatment to which all human thought and feeling needs to be continuously subject, yet all future progress in the matter can be only in the direction of its better understanding and fuller appropriation. At the same time it ought to be finally decided that we are going to interpret the meaning of sacrifice by the universal and eternal truth of it realized in the life and death of Christ, and not going to bring that truth down to fit into the little system of Jewish, or any other incomplete and imperfect human, thought or understanding of it. In other words, we shall interpret the sacrifice of Christ by itself, or in its independent and inherent 
significance, and make use of all prior meanings or uses of sacrifice as only pointing to and not at all sufficing to express or explain it.

One other principle or method of procedure I wish to make plain. As humanity will never be known except in the completeness of its exposition in Jesus Christ, so Jesus Christ cannot be known except in most essential and universal terms of our humanity. To understand our Lord in any act or situation of human life it is necessary to understand what is the eternally proper or right human attitude or action in that situation. And so in general I would say that what Jesus Christ did in our humanity in order to be our salvation was just precisely what humanity needed of itself to be and to do in order to be saved. We exactly express or explain any act of I Iis, and so the supreme and decisive act, when we say that humanity did it in His person, and that it was just precisely what humanity needed to do in order to its own redemption and completion. In His person humanity righted itself with God, redeemed itself from sin, raised itself from death. ... U U to the present point I would answer to any question of how we are saved by the death or the blood or the sacrifice of Christ simply in the well-known line of the poet: In $\mathrm{H}$ is death our sins are dead (pp. 125-7).

Here there are two paragraphs, of which the second is both important in itself and very characteristic of the author's thought. But as it will come before us later in another conmexion, I will not say more about it now. I might even have postponed the quotation of this second paragraph, but for the fact that the exposition of our present subject would have been too incomplete without it; and the two paragraphs together really take us to the centre of the matter.

In regard to the first paragraph, I would express 
the pleasure with which I read Dr. Du Bose's statement. It has all the philosophic breadth and care to which we are accustomed from him; the warning that we must interpret the lower by the higher, and not the higher by the lower, is very far from being superfluous. And yet I am very glad that so modern a thinker should not discard but should rather emphasize the conception of the Death of Christ as a sacrifice. As one who comes to these questions from different antecedents and from a different point of view, I welcome the more than usually sympathetic treatment of the ideas I cherish from Dr. Du Bose. He does not, I rejoice to say, dismiss the idea of Vicarious Suffering, or even the idea of Substitution. It would be more than human to expect that, holding the philosophy that he does, he should do otherwise than (as I should put it) try to minimize the force of these conceptions. It seems to be something of a relief to him, having recognized their reality, to be able to pass on and leave them behind. I should like, for myself, to go a little further than this; I should like to dwell upon the place that, if we look steadily at it, Vicarious Suffering really holds in the nature of things and, mysterious as this dispensation of Providence may be, I should like to dwell on the deep pathos and beauty of it from the side of the sufferer.

\section{V}

A marked characteristic of Dr. Du Bose's work is its freshness, independence, and originality. I have said that it all hangs together as an interconnected 
XI. 'The Gospel according to St. Paul' 305

whole. Even where he is continuing the thought of others, that thought has passed through the crucible of his own mind, and it comes forth as his own. But in some cases I suspect that the originality goes bejond this. The following is striking:-

We have then to inquire into the meaning of our Lord's having come in the likeness of sinful flesh, or of the flesh of sin. From the longest and most careful reflection upon the language and the matter of the New Testament, I am unable to accept the words as containing in themselves the implication that our Lord came into a nature or condition which was like but was not the flesh of sin. I feel the theological or doctrinal difficulty, but I also feel that that, and that alone, is the reason or excuse for modifying the meaning of words which are nowhere else so modified. I should much rather meet the real difficulty some other way; or, if I cannot fairly do so, then face it squarely. Like and likeness in the New Testament do not mean "like, but different'; they mean like in the sense of identical. When our Lord was made, or became, in the likeness of men, He did not become something similar to but not the same as man; He became man. When $\mathrm{He}$ was tempted in all points like as we are, $\mathrm{H}$ is temptations were not in some points only and not in others like our own; they were essentially and identically our own, with the sole additional circumstance, which does not affect the nature or character of the temptations, that whereas all we are overcome by them, He overcame them. And, humanly speaking, that is all the difference between sin and holiness. Sin or holiness cannot be in mere nature or condition; they can be only in what we are or do in the nature or the condition (pp. 22 I f.).

In accordance with the argument of this fundamental passage there are a number of places in which it is RECON. 
insisted that the victory of Christ over sin must be in all ways parallel with ours ("there was that in Him which $\mathrm{He}$ needed to deny, to mortify, to crucify,' p. I 73 ; cf. pp. I07, I 35, 144, I 74, \&c.). I am not prepared to challenge the conclusion as a whole; on the contrary, I believe that it may be defended both philosophically and exegetically; but I am afraid that I must challenge at least one important premiss on which it rests. It is a very sweeping and untenable statement to say that "like and likeness in the New Testament... mean like in the sense of identical'. We have only to think of the formula so frequent in the Gospels, 'the kingdom of heaven is like, or likened, unto' mustard seed, leaven, \&c. Every one knows that 'like' in these cases is very far from implying identity; the use is rather wide and lax, and denotes sometimes even a small degree of resemblance.

Another very questionable statement is the following :-

St. Paul objects to the mediator in the phraseology of Christianity, because a mediator is not of one but of two; whereas God and man are not two, but one in Christ, and there is nothing, not even a mediator, between them (p. 243).

Surely it is forgotten here that the one instance in which St. Paul does exclude the word 'mediator' (Gal. iii. 19, 20) has nothing to do with Christianity, but has reference to the promise of God in the Old Testament. On the other hand, I Tim. ii. 5, Heb. viii. 6, ix. I 5, xii. 24 expressly affirm the use of the word in Christian phraseology. 


\section{XI. 'The Gospel according to St. Paul' 307}

In the same context exception is taken to 'communion or fellowship' as inadequate renderings of koinonia.

I object to the words communion and fellowship simply as not going all the way of that unity of God and man in Christ which is the truth of the Holy Ghost. The truth of the Spirit of God is the truth of the spirit of man. The koinonia is not real or complete so long as the spirits are two and not one. We have it in its completeness only as the eternal, personal Spirit of God is the actual personal spirit of the man.

Doctrinally (as we shall see) this is important, and I should not wish to question it. But, for myself, I have always regarded 'communion' as the exact equivalent of koinonia; it surely means an actual sharing in, actual partaking of, or joint possession. But to say this is not to say that it means complete absorption, or identity.

As I am upon these small points, I may perhaps just mention two rather disconcerting misprints on page 131: line 8 from bottom, 'place' should be 'peace'; on page 22, line I6, 'prophecy' should, I think, be 'prophesy'. Three Greek words occur in the book, and two of these have wrong accents. As in the previous volume, there are one or two examples of doubtful grammar; to us in the old country such a construction as this would not be tolerable, 'it is not part God and part we, but all God and all we' (p. 37, cf. p. 32); we should avoid it somehow, probably by saying 'part God and part ourselves'. 
I suppose that the most really central and really important of all the problems discussed in the book is that relating to what Dr. Du Bose himself calls 'the universal humanity of our Lord', that property of His Person by virtue of which He not only represents but expresses 'the universal right mind of humanity'. We have already quoted (p. 303 supra) one significant passage in which this difficult conception is applied with marked lucidity. I will place by the side of this another, also very lucid, which I think not only helps to explain the idea but also helps us to understand its genesis.

All the Old Testament promises fulfilled in Christ were primarily promises made to humanity, and to be fulfilled finally only in the general life and destiny of man. The interpretation of one such promise, which will do for all, may be studied in the second chapter of the Epistle to the Hebrews. There is a promise made to man that, though for a time made lower than the angels, he shall be exalted above them and to the head of God's creation. Now as yet we see this promise very far from fulfilled in man, or in humanity at large, but we do see it most completely fulfilled in one man, Christ Jesus; and fulfilled in Him as head and representative and forerunner of all. It pleased God, for and through whom are all things, in bringing many sons to glory, to perfect (first) the Captain of their salvation. The promises are made generally to man; they are fulfilled first in the Son of man; and then through $\mathrm{Him}$ they are fulfilled in all who are in $\operatorname{Him}($ p. I 20). 


\section{XI. 'The Gospel according to St. Paul' 309}

We are familiar with this aspect of Biblical Prophecy and its interpretation. We are familiar with the subtle and easy transitions from collective to individual personality, and vice versa. We know how the ' I' of the Psalms often stands for the community. We know how the Servant of Jehovah represents the nation in terms of the individual and as finding expression from time to time in some select individual. We know how (e.g. in Ps. lxxxix. 19-45) the promises to David and to Israel pass into each other, and are finally fulfilled in a personal Messiah. This alternate expansion and contraction of idea is undoubtedly characteristic of the Bible. There is also something very like it in the Patristic treatment of the Person of Christ. Dr. Du Bose may well claim to have upon his side in what he says on this head both 'the truth of the Scripture and the mind of the Church'. He also has the emphatic agreement of such a modern as Dr. Moberly.

And yet such teaching is sure to be called in question. It is bound to be rejected by all Individualists in philosophy. When I reviewed Atonement and Personality in I90 I had not a little hesitation on the subject myself; but I may be allowed to say that since that date I have been more and more led to think that my English friend and my Amcrican friend are right.

It cannot be said that the latter has not the courage of his opinions, or that he fails to meet the difficulties involved in them fairly and squarely. He states the principal objection thus :- 
One says, "You lay great stress upon the view that our Lord was not a man, but man. I find this a difficult conception; does it mean that humanity has a concrete real existence apart from the individual persons who are human, and that this Universal becomes visible in Christ? If this be so, does it not lead us to a metaphysical Realism, not now generally held ?' (p. 297).

The answer Dr. Du Bose gives is as follows :-

The universality of our Lord's humanity is only explicable upon the fact that $\mathrm{His}$ personality is a divine one. It is only God in it that can make it applicable to all or the truth of all. And since, according to St. Paul, it is always Christ Himself who brings Himself to us and makes all that is His our own, it follows that, according to St. Paul, Jesus Christ can be to us nothing less than divine. The concrete universal of humanity which may be found in Jesus Christ belongs to it not as humanity but as God in humanity. It is God in it which makes that particular humanity of our Lord, His holiness, His righteousness, His life, valid and available for all ; so that every man may find himself in Christ, and in Christ find himself (p. 297).

It is substantially the same answer that (as I showed in my previous article) is given by Dr. Moberly. There is only this difference, that Dr. Moberly refers this all-embracing activity more explicitly to the Holy Spirit, who is the Spirit of Christ and of God. It is of course only a difference of language, the meaning is precisely the same. The Holy Spirit is the bond which binds all humanity together in one. In each one of us $\mathrm{He}$ is present after our measure, but in Christ $\mathrm{He}$ dwelt as the fullness of the Godhead bodily. It is that fullness of indwelling which gathers together 


\section{XI. 'The Gospel according to St. Paul'}

the multitudinous units into Him and communicates His experiences to them.

The whole work of Jesus Christ in humanity must be expressible, whether or no we may succeed in expressing it, in terms of distinctively human activity and experience, human effort and attainment, human predestination and realization. Jesus Christ accomplished and became precisely what it was the proper and destined task of humanity in Him to accomplish and become. This is not to say that the work of Christ is not equally expressible in terms of the divine activity. Jesus Christ means to us, what God is, and has done, and is doing in humanity. God was and is in Christ, reconciling the world unto Himself, imparting Himself to us and taking us up into participation with Himself. But God is in us only what we are in Him, and God does in us only what we do in Him; and what that is, must be as perfectly expressible in terms of us as of Him (pp. 225 f.).

\section{The reciprocity is perfect:-}

The complete being in Christ means the complete being of Christ in us. The branch is completely in the vine only when the life of the vine is completely in the branch (p. 234).

I know nothing more instructive than that parable or allegory of the Fourth Gospel. As the sap circulates through the vine, so do spiritual forces circulate through that Body of which Christ is the Head; and life in circulation carries with it the properties of the source from which it springs.

I will only speak of one more difficulty which Dr. Du Bose directly meets, so far as it can be met. Here, too, there is no flinching.

One says, 'My difficulty is as follows: The agony 
in the Garden and the cry of My God, my God, why hast thou forsaken me? seem to show that our Lord was as personally distinct from God as we ourselves are, that $\mathrm{His}$ personality, $\mathrm{His}$ self-consciousness and will, was not a divine personality, but a human; so human as to be capable of losing its hold upon God, just as we may lose our hold upon God' (pp. 298 f.).

This is just a case where Dr. Du Bose's thoroughgoing humanizing (if I may so call it) of our Lord stands him in good stead. He asks whether we should wish 'to construe these experiences of our Lord into some other, non-human experiences'. And then he goes on to ask if the whole difficulty is not 'already expressed for us in the very word Incarnation; a difficulty which the most of us evade by simply not taking the word seriously, in the fullness and reality of its meaning?' He adds: 'In the instance we have been analysing, what do we see but the disposition common to us all to find in our Lord's temptation experiences that are not human, and in Himself one who was not truly man' (p. 30I).

This is precisely the kind of language used (as I also showed before) by Dr. Moberly, who deprecated the attempt so often made 'to keep open, as it were, a sort of non-human sphere, or aspect of the Incarnation'.

It is a pleasure to me to bring out once more the harmonious thinking of my two friends. Dr. Moberly has no nearer or truer successor than the American theologian whose work $I$ have been studying, more than 4,000 miles away. 


\section{APPENDIX}

A SERMON ON ANGELS 



\section{A SERMON ON ANGELS}

St. Matthew xviii. 10: "See that ye despise not one of these little ones; for I say unto you, that in heaven their angels do always behold the face of my Father which is in heaven.'

What are we to say of this article of ancient faith that we commemorate to-day? Does it simply belong to the poetry of old religion? Was it just in that sense, and in no other, that it was accepted by our Lord Jesus Christ and His Apostles? Or is there not in it something more than this?

In any case, the words of my text which come from the Gospel that has just been read are the strongest argument we have for attaching a higher value to the old teaching. They show that our Lord Jesus Christ did Himself make use of this belief in Angels, and use it to express truths that were very near His heart. We know what a tender place there was there for those whom $\mathrm{He}$ called 'the little ones who believe in $\mathrm{Me}$ '-whether $\mathrm{He}$ is speaking of young children or of those who are (as He would have them be) like children in innocence and openness of character and life.

We must distinctly recognize that there were many of the popular beliefs of His time that our Lord did accept and did condescend to use very much in the way in which $\mathrm{He}$ accepts this. We note the fact; and, in doing so, it is important that we should give it just the degree of significance that belongs to it-not less, but also not more.

Let us take another rather striking example. You will remember how our Lord describes the state of the 
man who after he has been converted from his evil way returns to it again: "The unclean spirit, when he is gone out of the man, passeth through waterless places, seeking rest, and findeth it not. Then he saith, I will return unto my house whence I came out; and when he is come, he findeth it empty, swept and garnished. Then goeth he, and taketh with himself seven other spirits more evil than himself, and they enter in and dwell there : and the last state of that man becometh worse than the first' (St. Matt. xii. 43-45).

It is a very graphic but at the same time a very simple description, one that the poor people sitting round who heard it would at once enter into and understand.

But it does not at all follow that, because our Lord spoke in this way to them, He would therefore have spoken in the same way to us, if His incarnation had taken place in the twentieth century of our era instead of in the first. We are told that $\mathrm{He}$ was made in all things like unto His brethren (Heb. ii. I 7), where ' His brethren' means in the first instance those among whom he lived and moved. Nor was there, I think we should add, any conscious accommodation in this. We must not confuse the natural and beautiful simplicity with which our Lord spoke with the self-consciousness with which a superior person in these days sometimes lets himself down to his audience. There is a right manner and a wrong manner in such things ; and we may be sure, indeed we can see for ourselves, that our Lord's manner was absolutely right.

Well then, the way in which I would put it I think would be this. There are great truths which our Lord desires to express, and $\mathrm{He}$ gives them that mode of expression that is most suitable to the time and to the 


\section{Angels}

occasion, most intelligible and most effective for those whom $\mathrm{He}$ is addressing,

'the village-groups at eve or prime'

that gathered round $\mathrm{Him}$ and listened to His words.

It is a mode of expression which must be distinguished from the deeper truth expressed-not to be despised or treated slightingly, but on the contrary to be carefully' studied, and yet to be distinguished.

It is in that way that I think we should approach the words of my text. What is here the deeper truth, the permanent truth, the universal truth? It is, I suppose, that the little ones who believe in Christ are very dear in the sight of God; that they are very near to $\mathrm{Him}$; that if they are oppressed or deceived or led astray $\mathrm{He}$ is close at hand to hear their cry and to help them; yes, and also to punish those who oppress or mislead them-' it were better for that man that a millstone were hanged about his neck and that he were drowned in the depth of the sea'.

That I suppose we may take to be the deeper or more substantial truth of the verse we are considering. And now let us fix our attention not upon the substance but upon the form in which it is expressed: 'See that ye despise not one of these little ones' - be very careful of your conduct in all your dealings with them-'for I say unto you, that in heaven their angels do always behold the face of My Father which is in heaven'. It is the doctrine of guardian or representative angels, angels who are a sort of alter ego of the believer on earth.

It may be well for us just to try to follow out the history of this conception, to analyse the process which led up to it. That will take us rather further back still, to the origin of the belief in angels generally. When I speak of the origin of the belief, I do not mean that we 
need be involved in the technical discussions which have been going on for some time, as to how far the belief was indigenous in Israel itself, or how far it may have been imported from foreign sources, from the Babylonians or the Persians. We are more nearly interested in the psychological processes which led to the belief, or which caused it to take root among the people of revelation. I suspect that two motives were strongest in this direction: on the one hand the desire to enhance the conception of the majesty of God, and on the other hand the instinct of reverence which tended to remove Him from too close a contact with man.

When the Hebrew turned his thoughts towards the majesty of God, it was natural that they should move along the lines of that which was most sublime and most exalted in his experience as man ; in other words, that he should think of the earthly king upon his throne. In the first instance he would think of his own king at Jerusalem; but he would be aware that his own state was but a small one, and his thoughts would pass on to a mightier monarch, to Nebuchadnezzar at Babylon, or to the Persian who called himself the Great King at Susa. The Persian monarchy, with its more elaborate organization, with its satrapies or provinces and the provincial governors receiving their orders regularly from the capital, impressed his imagination. This was the type on which he modelled his idea of God. Our own poet has caught it exactly :-

His state

Is kingly; thousands at his bidding speed

And post o'er land and ocean without rest.

The angels are the retinue of God, His celestial messengers and apparitors whom $\mathrm{He}$ sends to and fro to convey His commands and carry out His behests. 
That was one source of the conception; and the other was, as I said, the instinct of reverence, the instinct which led men as time went on to think of God as further off. At the dawn of reflection they thought of Him as holding converse with our first parents, as walking with them in the garden in the cool of the day. But they soon came to think of such familiar intercourse as derogatory to the majesty of God. They began to interpose links between God and man, intermediary beings between earth and heaven. When Jacob dreamed his dream of special communion with God, it took the form of a ladder set up on the earth, with the top of it reaching to heaven, and the angels of God ascending and descending on it. This remained the standing type of spiritual communion with God. Our Lord's promise to Nathanael was: 'Verily, verily, I say unto you, $\mathrm{Ye}$ shall see the heaven opened, and the angels of God ascending and descending upon the Son of man' (St. John i. 5I), describing in these terms His own uninterrupted communion with the Father.

I imagine that here too, in this view of the function of angels, there is the same idea of a great Oriental palace and royal court in the background; the angels as it were occupied the ante-chamber, through which alone there is access to the royal presence, and it is they who bear communications from without to the King. ${ }^{1}$ The leading motive throughout all these quasipictorial representations is reverence.

In the particular picture of the guardian angels of children, and generally of the weak and humble, beholding the face of God, another set of ideas is at work.

1 It is pointed out to me that there is a close parallel to $\mathrm{my}$ text in Esther i. 14, "the seven princes of Persia and Media, which saw the king's face and sat first in the kingdom.' 
We speak of the ideals of things as though they were distinct from the reality. Plato spoke, not exactly of ideals, but of the ideas of things, the divine design in accordance with which they were made, as though they had an objective existence. The Jew of our Lord's day spoke of the pattern of holy things laid up in the heavens. In this way he came to think of a sort of spiritual double of those who lived and walked on earth, a 'spirit-self' as it were detached from the bodily self. This spirit-self had a nearer access to the presence of God, as purer and holier than that which was of the earth earthy. So arose the conception of what we have called guardian angels. The reminder that the guardian angels of the little ones below look for ever into the face of God is, as I said, a reminder how very dear those little ones are to Him.

That is broadly the meaning of the passage. It is out of place for us to come with our 'meddling intellect' and intrude the question, Are there really such things as guardian angels, and do they really stand in the presence of God? These are crude categories into which we try to squeeze conceptions that are not congenial to them. Our notions of reality are too much confined to literal, material reality. Another category, that is still rather crude, though nearer to the mark, is that which we call 'symbolism'. We may say, if we please, that the idea of guardian angels is symbolicalsymbolical of a truth in the nature of things, symbolical of something at once beautiful and true that we cannot express in any other way, but which the instinct of reverence and the certainty that all innocence and goodness, especially in the weak, is dear to God, inevitably demands. For the Christian it is enough that our Lord Jesus Christ Himself expressed it in this way. 
And I think we may extend this to all the belief in angels. I said at the outset that it did not follow that, because our Lord spoke as $\mathrm{He}$ did to His disciples, therefore $\mathrm{He}$ would have spoken in the same way to us, if He had come to us in the twentieth century and not in the first. Perhaps I should correct myself a little there. I think we might say with some confidence that our Lord would not speak in this way to a Faraday or a Huxley, if $\mathrm{He}$ met them at some rich man's table. But I am by no means sure that $\mathrm{He}$ would not still use the same language as of yore to the young, to the 'little ones'-whether old or young, to 'village-groups at eve or prime'.

And he would be a bold man-or rather, a very dull and senseless man-who should take upon himself to say that the language used to the man of science was true, and that used to the poor and simple untrue. Both modes of speech would be equally true in their context.

Perhaps I can illustrate the different language suitable in these different connexions by the help of two poems, one mediaeval and one modern. The first is from a translation in measured prose of an old Irish poem put in the mouth of St. Columba, and celebrating the praise of the chief foundations of his order. The poet has a touching love for his own home at Derry.

Were the tribute of all Alba mine,

From its centre to its border,

I would prefer the site of one house

In the middle of fair Derry.

The reason I love Derry is

For its quielness, for its purity,

And for its crowds of white angels,

From the one end to the other.

fECON. 
The reason why I lore Derry is

For its quietness, for its purity,

Crowded full of hearen's angels

Is every leaf of the oaks of Derry.

$\mathrm{My}$ Derry, my little oak-grove,

My dwelling, and my little cell ;

O Eternal God, in heaven above,

Woe be to him who violates it!

The delight of the poet in his little cell is a feeling partly natural and partly religious. It is in part a natural attachment to a cherished home, but it is even more a sense of consecration, of God's presence brooding over it. And then the feeling of reverence comes in ; the poet checks himself from thinking or speaking too freely of the presence of the Almighty; but he has less scruple in thinking or speaking about angels, and he feels their presence all about him. Observe how beautifully his ideas harmonize together and blend into a single picture of sanctity.

The reason I love Derry is

For its quietness, for its purity,

And for its crowds of white angels,

From the one end to the other.

The reason why I love Derry is

For its quietness, for its purity,

Crowded full of heaven's angels

Is every leaf of the oaks of Derry.

Quietness and purity are naturally associated with angelic visitation.

The modern poem that $I$ have in my mind is familiar to all lovers of poetry. It, too, turns upon a sense of consecration; but you will see that the angels have dropped out, and the instinct of reverence is satisfied in another way; the feeling of a divine 
presence is hinted at and implied all through, but it is nowhere directly described; it is rather suggested through its effect upon the human soul (as in the figure of the nun). I am referring to Wordsworth's well-known sonnet.

It is a beauteous evening, calm and free:

The holy time is quiet as a nun

Breathless with adoration; the broad sun

Is sinking down in its tranquility;

The gentleness of heaven is on the Sea :

Listen! the mighty being is awake, And doth with his eternal motion make

A sound like thunder-everlastingly.

Dear child! dear girl! that walkest with me here If thou appear untouch'd by solemn thought Thy nature is not therefore less divine:

Thou liest in Abraham's bosom all the year, And worship'st at the Temple's inner shrine, God being with thee when we know it not.

The personifications, or quasi-personifications, in which the ancients delighted have become less congenial to the modern mind. We are aware that the white figures with wings, and Michael with his sword and plume, that we see in picture-books or on our walls are conventional representations that have no exact counterpart on earth or in the sky. But none the less we believe that they were an effort to express a true idea. The true iclea is that the space around us and above us is not merely blank or vacant, but full of God's presence. His watchful care reaches to us and sustains and protects us every one. It is possible that for this purpose He makes use of some intermediate forms of being. But whether that is so or not, we cannot tell. Any language that we: allowed 
ourselves to use on that head could only be the language of symbol. Science I suppose has brought to light that the space that we used to think blank is really filled with an almost infinitely attenuatedether. There may perhaps be something corresponding to that in the world of spirits. We believe that those who have gone from us look down upon us at our earthly tasks even now; and there may be other spirituai existences besides theirs. What we lack is the sense to discern them. We are like Elisha's servant at Dothan, waiting for our eyes to be opened so that we may see the chariots of fire and the horses of fire. What may be revealed to us some day we do not know; but one thing we do know. We do know that a deep truth underlies our Lord's words about the angels of the little ones who behold the face of their Father who is in heaven.

And it is most interesting to note that the modern poet has really caught this same truth. He certainly had not our Lord's words in his mind. It was a discovery that he made for himself-that it is a privilege of childhood, of true childhood, to have God always at hand, to feel the presence of the other world, without making any outwardly visible sign. In other words, to say that childhood worships at the inner shrine, that it lives in the full light of God's favour and God's blessing while we know it not, is but the equivalent in modern language of the picture which our Lord draws of the guardian angels with upturned faces before the Throne. 


\section{N D E X}

Abbott, Edwin A., 4o f.

Absalom, Revolt of, 18.

Acts, Criticism of, I62 ff., $168 \mathrm{ff}$, $212 \mathrm{ff}$.

Allen, W. C., 173.

Angels, 315-25.

Apocalypses, 20 ff., 47 ff., 52 f., I08.

Apocalyptic, 30, 32 f., 46 ff., 108-18, 126.

Apollonius of Tyana, 206 f., 209.

Arnold, M., $224 \mathrm{f}$.

Asceticism, 63 .

Atonement, $23 \mathrm{I}$ f., 244-5 I, $268 \mathrm{ff}$.

Augustine, St., quoted, $216,223$.

Baldensperger, $48,53 \mathrm{ff}$., 78 .

Baptism, The, II 132 f., 272.

Baptism : see Sacraments.

Bebb, 163 .

Beth, 177 .

Beyschlag, $9 \mathrm{I}$.

Bousset, 50 f., 63 f., 75 f., 9I, 177 , 179-92.

Burkitt, 59, 95 f., 99 .

Butler's Analogy, 238, 255 f.

Cambridge Theology, $39 \mathrm{f}$.

Charles, 39, 47.

Chase, 163.

Chiliasts, 114.

Christianity defined, $279 \mathrm{f}$.

Christlieb, M., 177.

Christology, 89, 129, 184, 233 f., 263 ff., 272 ff.

Collective use, 195, 309.

Communion, 307.
Continuity, I82.

Cosmogony, $16 \mathrm{ff}$.

Covenant, $14 \mathrm{f}$.

Creeds, $178,187 \mathrm{f}$.

Cross, Cry on the, 87 .

Dalman, $65 \mathrm{ff}$.

David, Son of, 137 .

Decalogue, 19.

Development in Jesus, 92, $96 \mathrm{f}$.

Dillmann, 47 .

Dreams, 7 f., $2 \mathrm{I}$.

Driver, $66 \mathrm{f}$.

Du liose, 152, 157, 257-312.

Dyce, W., R.A., v, 29.

Early Church, 74, 109, 157, 159 f.

Edersheim, 48, 91 .

Elijah, 31 ff., 79, 85, 110 f., 210 f.

Elisha, 210 f.

English Theology, 38 ff., 146 ff., 163,255 f.

Eschatology, 46, 62 ff., 77 f., 87, 89, 97-101, I04-7, III-I8, I19-22, $138,160$.

Esoteric: see Mystery, Secret, 82, I 26.

Exodus, The, 18, $210 \mathrm{f}$.

Exorcism, 24, III.

Ezekiel, 28, I 10, 2 I2.

Faith-healing, 222.

Fatherhood of God, 130-3, 234 .

First Man, 233, $274 \mathrm{f}$.

Five Thousand, Feeding of the, IO4 ff.

Folklore, 18, 2 Io $\mathrm{f}$. 
Forerunner, 59, 63, 79 .

Forgiveness, 235 ff., 239-44, 270, 290-300.

Fourth Gospel, 106 ff., I33, 137-9, 141, 160, 22 I.

\section{Garrod, 79.}

German Theology, 37 f., 41 f., 123 , $162,187 \mathrm{ff}$.

Godhead, Representation of, 9 ff., 19 f., 2 II.

Gospels, Trustworthiness of, $100 \mathrm{ff}$., $125,213,220 \mathrm{ff}$.

Gritzmacher, R. H., 177.

Harnack, 62, 76, 154, 161-6, I $68 \mathrm{ff}$. Harris, Rendel, 47.

Hase, I04.

Hastings, 4o.

Hatch, 41 .

Haussleiter, $179 \mathrm{ff}$.

Hawkins, Sir John C., 39, 163.

Headlam, 163.

Hermann, 177.

Hilgenfeld, 47.

Historians, Hebrew, $15 \mathrm{ff}$.

Hobart, 163.

Holtzmann, H. J., 90 f., 104, 193 f.

Holtzmann, O., $9 \mathrm{I}$.

Humanitarian, 109.

Humanity, 127, 184, 303, 308-12.

- of Christ, 184 f., 233, 263, $273 \mathrm{ff}$., 308-12.

Humiliation of Christ, $277 \mathrm{f}$.

Illingworth, 152.

Immanence, 153 .

Incarnation, $232 \mathrm{ff} ., 276,305,312$, 316,321 .

Inge, 152.

Inspiration, 16, 183, 187, 205, 210.

Interimsethik, 58, $16 \mathrm{I}$.

Issel, 56.
James, 39, 47.

JESUS CHRIST, Deity of, 119-41, I 79 f., I 85, I 89 ff.

- Human character of, $140 \mathrm{f}$.

Jewish Church (temp. Chr.), 5 I f.

Jewish scholars, $49 \mathrm{ff}$.

John the Baptist, 3 I ff., 79, 84 f., 110 f., IIg.

Jonah, 212.

Josephus, 100.

Judaism, 49 ff., 60 f., 99, 16 I.

Jülicher, 72, 82, 155, 166-71.

Justification, 242, 287-304.

Kaftan, J., 115 f., 175 f.

Kaftan, Th., $175 \mathrm{ff}$., $180 \mathrm{ff}$.

Kautzsch, 65.

Keim, 90.

Kenotic teaching, $277 \mathrm{f}$.

Kingdom of Heaven (or of God), 56, 58 ff., 115 ff., 119 ff., I2I f., $159 \mathrm{f}$.

- Secret of the, 78, $80 \mathrm{ff}$.

Knowling, 163.

Koinonia, 307.

Last Supper: see Sacraments.

Law, $301 \mathrm{f}$.

- Giving of the, $18 \mathrm{ff}$., $210 \mathrm{f}$.

Liberal Theology, $90 \mathrm{ff} .$, I 75, I $79 \mathrm{ff}$., 197, 200.

Lietzmann, 65 ff., 101.

Lightfoot, I63.

'Like' in N. T., 305 f.

Lives of Christ, $90 \mathrm{f}$., 261.

Logos, 138, 279 f.

Luke, St., 133, $164 \mathrm{ff.}, 168 \mathrm{ff}$., 21 5-19.

Magic, $207 \mathrm{ff}$.

Maran atha, 113.

Marcan hypothesis, 94.

Mediator, 306.

Meekness, $265 \mathrm{f}$. 
Mercy, $240 \mathrm{f}$.

Messiah, 87, 123, 1 34-7, 1 58, 1 89-94.

- Woes of the, 83 .

Messiahship, secret of, $69 \mathrm{ff}$., $78 \mathrm{ff}$., 119 ff., 121 .

Messianic Feast, 104 f.

Meyer, A., $65 \mathrm{f}$.

Milligan, 9, 59.

Ministry, duration of our I.ord's. $97 \mathrm{ff}$.

Miracles, $102 \mathrm{ff}$., 203-25.

Moberly, 41, 44, 1 52, 229-56, 26-f., $27+$ ff., 278,286 ff., $288-312$.

Modernism, 103, 237, 263, 316 f., 321.

Moffatt, 149, $16 \hat{3}$.

Mystery, $78 \mathrm{ff}$., 12 1, 238 f., 245, 256: see Messiahship, secret of.

Mysticism, 153 .

Natural, $2 \delta_{3}$.

Nestorianisin, 234.

New Testament, 187, 206, 21 2-25.

New Theology, 149-54.

Nöldeke, 65 .

Northern Journey, 85 f., 96 .

Occultation, 136,141 .

Old Testament, iso f., I87, 209 is.

Oxford Theology, $39 \mathrm{ff}$.

Paedagogic, 92.

Pantheism, 252.

Parables, 25 f., 72.

Passion, Predictions of, $73,93,120$ : sce also Suffering.

Patristic Theology, 277, 309.

I'aul, St., 112 ff., I 31 ff., 2 I 3 ff., 219. 284-312.

l'enitence, $235 \mathrm{f}$.

l'entecost, $115 \mathrm{ff}$., $122,236$.

Person, 233.

Personality, 251-5, 268 .

Peter's Confession, 78 , 8o, 120.
Philo, 139.

Philosophy, $25 \mathrm{Iff}$., 262 f.

Philostratus, $206 \mathrm{f}$.

Political ideal, 61, 8I f., 93, 99 f., I $36,158$.

Positive Movement, $175 \mathrm{ft}$.

Prayer, Answers to, $204 \mathrm{f}$.

Prediction : see Prophccy, l'assion.

Prophecy, 22 f., 118 : sic I'assion.

Prophet, Jesus as, $84 \mathrm{f} ., 97 \mathrm{ff}$.

Prophets, $4 \mathrm{ff}$., $211 \mathrm{f}$.

I'ropitiation, $247 \mathrm{ff}$.

Psychology', 92, 94 ff.

Punishment, 235.

Rabbinism, $48 \mathrm{ff}$. $62 \mathrm{ff.}$. I1, $1 \div 6$. $25 \mathrm{I}$.

Rackham, 163.

Ramsay, Sir 11. $11 ., 163,171 \mathrm{f}$. 207 f.

Rationalism, 102, 161.

Realism, 108 f., 110.

Redemption, 58, 96.

Remission: see Forgiveness.

Renan, 90.

Repentance, $84,271$.

Resurrection, The, 73.75 f., 132 .

Ritschl, 153.

Robinson, J. A. (I)ean of IVestminster), 40.

Rushbrooke, 40.

Sabatier, A., 153.

Sabellianism, 233 .

Sacraments, $105 \mathrm{f}$.

Sacrifice, 14 f., $246 \mathrm{ff}$., $302 \mathrm{ff}$.

Salmon, 149, 156, 16j, 1; 2 f.

Satan, 29, 110.

Fall of, 30 f., 111 .

Scepticism, 76, 157, 28j.

Schenkel, 90, I04.

Schmidt, I'. IV., 91.

Schmiedel, 131.

Sichmoller, 56. 
Schürer, 6I f., $163 \mathrm{f}$.

Schweitzer, 42 f., 44 ff., 59 f., 68 f., 77-89, 91-I06, 108, I37, I 59, $167 \mathrm{f}$. Scott, E. F., $148 \mathrm{f}$.

Secret : see Messiahship, Kingdom, Suffering.

Seeberg, R., $176 \mathrm{ff}$, I 80, I $82 \mathrm{ff}$. Silence, Injunctions of, 72, $120 \mathrm{f}$.

Simplification, 187.

Sinful flesh, $305 \mathrm{f}$.

Soden, Freiherr von, 62, 91, 155.

Soltau, 155 .

Son of David, 137.

Son of God, $87,123,130-3,137 \mathrm{f}$, 234.

Son of Man, 59, $65 \mathrm{ff}, 87$, I00 f., 123-30, 159, 190-6.

South, University of (U.S.A.), 257 f.

Spirit, Holy, I 5 ff., I 22, I 82, 233 ff., 236, 274, 292, 310.

Steinmann, $42 \mathrm{ff}$.

Strauss, 90 , IOI $\mathrm{f}$.

Suffering, Secret of, 78, 83, 121.

Supernatural, 61, 64, 77, 79, 102.

Swete, 40.

Symbolism defined, 3 f., cf. II f., 17, 39, 321.

Synoptic Problem, 39 f., 155 ff., $164 \mathrm{ff}$, $171 \mathrm{ff}$.

Talmud : see Rabbinism.

Teacher, Jesus as, 84, 97 ff., 159.
Temptation, The, 27 ff., 109 f., $262 \mathrm{f}$.

Theodicy, 238, 255 .

Theophany : see Godhead.

Tissot, 29.

Titius, 173.

Transaction, 236 f., $244 \mathrm{f}$.

Transfiguration, 86.

Trinity, $232 \mathrm{ff}$.

Tritheism, 233.

Triumphal Entry, 80, 86.

Turner, C. H., 39.

Twelve, Mission of the, $83 \mathrm{ff}$.

Two Natures, 234, 277.

Vermittelungstheologie, $\mathbf{1} 82$.

Versions, The, 39.

Vicariousness, 249-5 I, 304.

Virgin Birth, $272 \mathrm{ff}$.

Visions, $7 \mathrm{ff}$., $21 \mathrm{f}$.

Weinel, 42 f., 179.

Weiss, B., 56, 9I, $155,173 \mathrm{f}$.

Weiss, J., 56 ff., 62 f., 76, 78, 101, 155 .

Weizäcker, 91, 104.

Wellhausen, 60 ff., 65 f., 95, 97, IOI 154-61.

Wernle, 62, 91, 155, 179 .

Worship, Hebrew, $12 \mathrm{ff}$.

Wrede, 69 ff., 86, 9I, 94 .

Wright, A., 40.

Zimmermann, 155 .

Oxford: Printed at the Clarendon Press by Horace Hart, M.A. 




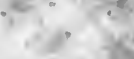
ation.

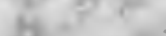

(\$)

y.

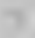

3

$$
-
$$$$
\text { is }
$$

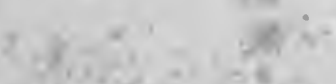

$*$

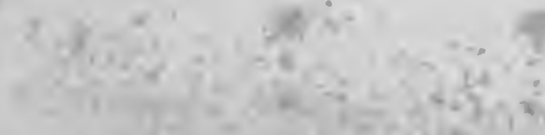

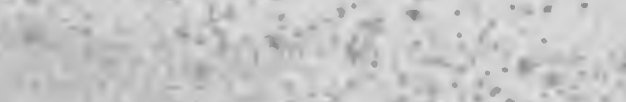

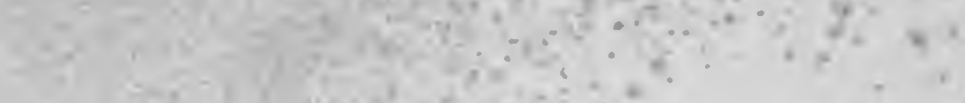

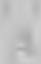

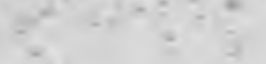

$+$

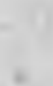

$\sqrt{2}$

an

$$
+2+4=
$$

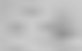




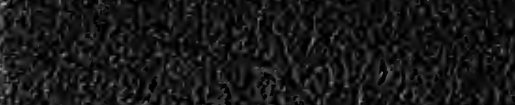

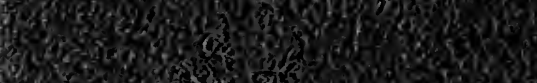

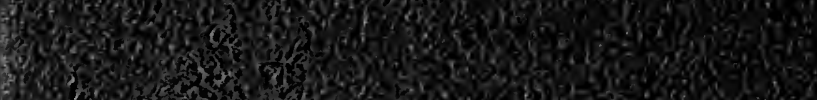

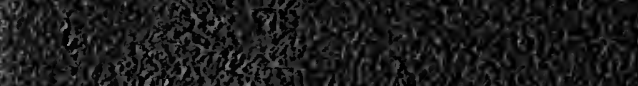

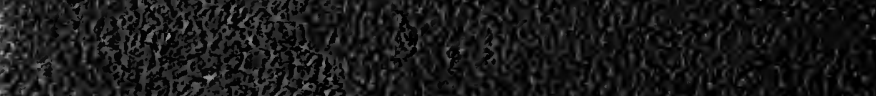

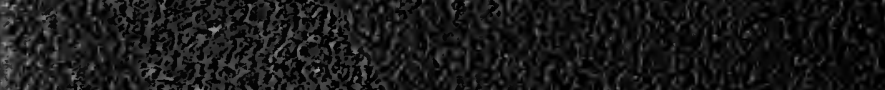

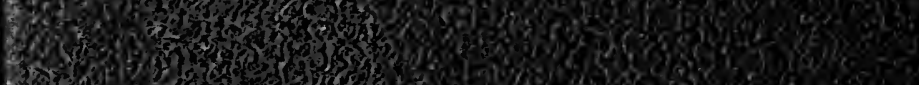

3. 02 -

3.

3 . 3 .

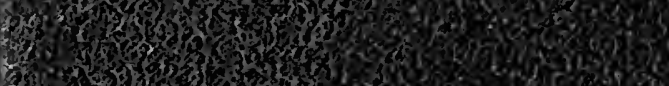

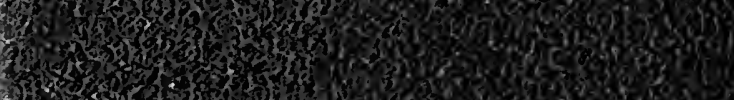

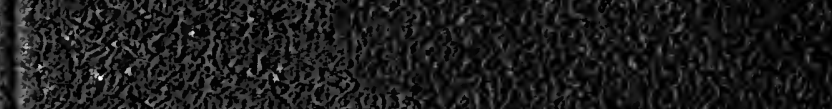

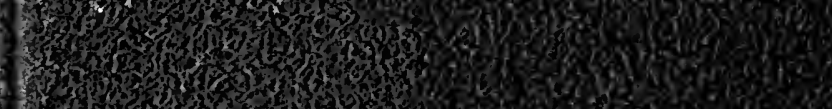

9.7.

3.1,

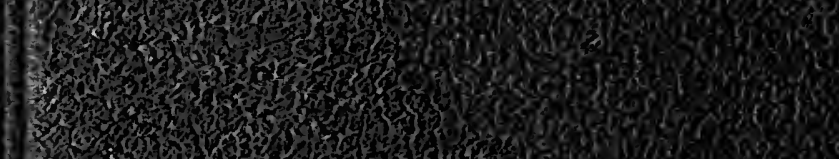

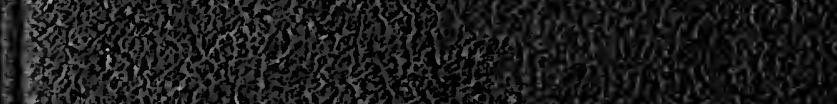

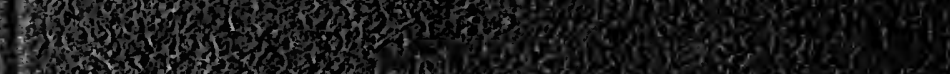

73.

39. 16 .

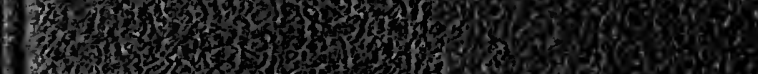

3.7.

H.

3.

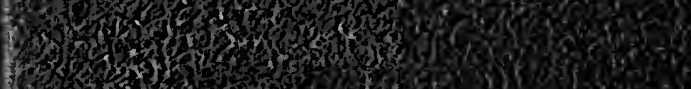

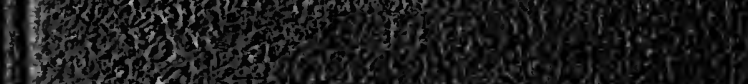

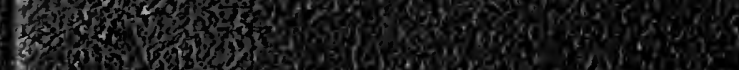

40.7 .

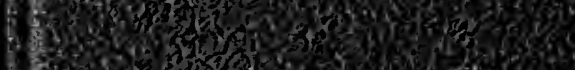

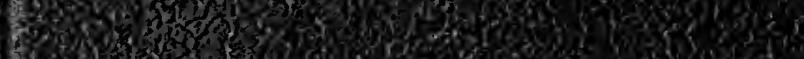

8

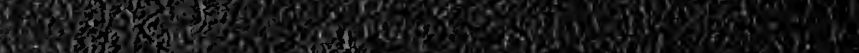

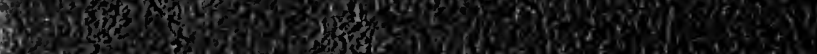

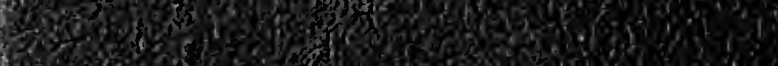

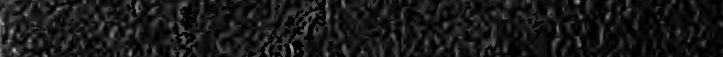

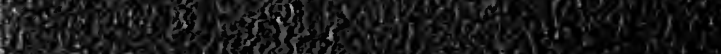

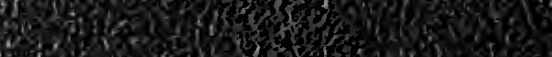

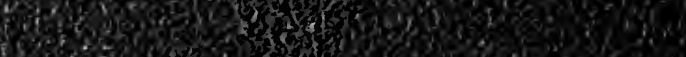

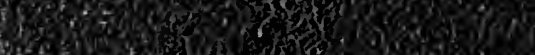

150 